RAFAEL EIJI TOMA

\title{
Comparação de juntas soldadas de aço inoxidável AISI 304 para aplicação em baixa temperatura utilizando-se a soldagem por arco submerso
}

\author{
Dissertação apresentada à Escola \\ Politécnica da Universidade de São \\ Paulo para obtenção do título de Mestre \\ em Engenharia
}

São Paulo, 2012 
RAFAEL EIJI TOMA

\section{Comparação de juntas soldadas de aço inoxidável AISI 304 para aplicação em baixa temperatura utilizando-se a soldagem por arco submerso}

Dissertação apresentada à Escola Politécnica da Universidade de São Paulo para obtenção do título de Mestre em Engenharia

Área de concentração: Engenharia Metalúrgica e de Materiais

Orientador: Prof. Dr. Sérgio Duarte Brandi

São Paulo, 2012 


\section{Ficha Catalográfica}

Este exemplar foi revisado e alterado em relação à versão original, sob responsabilidade única do autor e com a anuência de seu orientador.

São Paulo, 31 de julho de 2012

Assinatura do autor

Assinatura do orientador

\section{Toma, Rafael Eiji}

Comparação de juntas soldadas de ao inoxidável AISI 304 para aplicação em baixa temperatura utilizando-se a soldagem por arco submerso / R.E. Toma. --São Paulo, 2012.

$142 \mathrm{p}$.

Dissertação (Mestrado) - Escola Politécnica da Universidade de São Paulo. Departamento de Engenharia Metalúrgica e de Materiais.

1. Soldagem a arco 2. Aço inoxidável austenítico 3. Propriedades dos materiais 4. Baixa temperatura I. Universidade de São Paulo. Escola Politécnica. Departamento de Engenharia Metalúrgica e de Materiais II. t. 
Dedicatória

Dedico este trabalho a meus pais, Roberto e Luiza, e à minha irmã Carolina. 


\section{Agradecimentos}

Ao professor Sérgio Duarte Brandi, pela orientação e por compartilhar parte de seus conhecimentos, sem os quais a elaboração deste trabalho não seria possível.

À Lincoln Electric do Brasil, pelo fornecimento dos corpos de prova, realização das soldagens e por terem providenciado os ensaios mecânicos, especialmente ao Antonio Cordeiro Souza e Zorailde Morais.

A Leandro Justino de Paula (Laboratório de Fenômenos de Superfície), Raquel Camponucci Proiete (Instituto de Pesquisas Tecnológicas), Antônio Lívio da Silva Nunes (Departamento de Engenharia Metalúrgica e de Materiais) e Flávio Gil Alves Paiva pela prontidão em auxiliar na preparação dos corpos de prova.

Aos meus pais, Roberto e Luiza, pelo apoio nos momentos difíceis e por me incentivarem na vida acadêmica.

À Promon Engenharia, pelo patrocínio através de horas para estudo, e ao Oswaldo Boro pela flexibilidade de horário para execução deste trabalho.

A todos que colaboraram direta ou indiretamente na realização deste trabalho. 


\section{Resumo}

Aços inoxidáveis austeníticos são indicados para aplicações a baixas temperaturas por praticamente não apresentarem temperatura de transição dúctil/frágil. Quando estes aços são soldados há a formação de ferrita na zona fundida que, dependendo da morfologia e da quantidade, pode induzir uma temperatura de transição dúctil/frágil. Este trabalho busca estudar as propriedades mecânicas e microestruturais a baixas temperaturas $\left(-100^{\circ} \mathrm{C}\right)$ na zona fundida do cordão de solda. Chapas de aço inoxidável AISI 304 com 25,4 mm de espessura foram soldadas pelo processo de soldagem a arco submerso, empregando-se um arame ER 308L, e dois tipos de fluxos distintos: um neutro e um auto-compensante em cromo. Os procedimentos de soldagem foram realizados utilizando-se corrente contínua em polaridade reversa e corrente alternada de onda quadrada. Esta apresentou melhores resultados de tenacidade que a soldagem em corrente contínua para os dois fluxos estudados. Os corpos de prova soldados com fluxo neutro apresentaram maior tenacidade que os soldados com fluxo autocompensante em cromo, comparando-se o mesmo tipo de corrente na soldagem.

Palavras-chave: soldagem por arco submerso, aço inoxidável AISI 304, baixa temperatura. 


\begin{abstract}
Austenitic stainless steels are recommended for low temperature applications due to a very low ductile/brittle transition. When this stainless steel type is welded, there is formation of delta ferrite in the fusion zone which, depending on its morphology and distribution may increase ductile/brittle temperature transition to higher values compared with base metal. This work aims at studying the mechanical properties and microstructure at low temperatures $\left(-100^{\circ} \mathrm{C}\right)$ on the weld bead fusion zone using AISI 304 plates 1 inch thick which were welded with submerged arc welding process using ER308L and two different fluxes types: a neutral and a chromium auto-compensating one. The welding procedures were made using reverse polarity continuous current and square wave alternate current. The latter presented better toughness results than the continuous current for both fluxes types. The neutral flux led to greater toughness than the chromium auto-compensating flux, comparing the same current type output.
\end{abstract}

Keywords: submerged arc welding, AISI 304 stainless steel, low temperature. 


\section{Índice de Figuras}

Figura 2.1: Dimensões para os corpos de prova e dos entalhes para o ensaio de impacto tipo Charpy, segundo a norma ASTM E23 [5].

Figura 2.2: Variação de resultados no ensaio Charpy para diferentes temperaturas em diversos materiais metálicos. Adaptado de [4].

Figura 2.3: Representação esquemática do método para estimar CTOD a partir de medidas de COD [11].

Figura 2.4: Curva da carga em função do deslocamento, típica de um ensaio de CTOD. [11]

Figura 2.5: Representação de um contorno de linha em um sólido elástico não linear, usado para demonstrar a independência do caminho da integral $\mathrm{J}$ [11].

Figura 2.6: Contorno de integração utilizado na análise do uso de $\mathrm{J}$ como critério

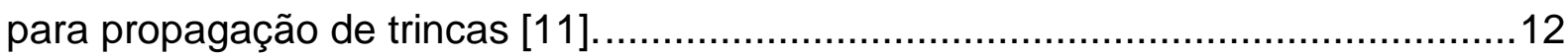

Figura 2.7: Projeção tridimensional de um diagrama de fases ternário [18].............14

Figura 2.8: Isoterma do diagrama de fases ternário Fe-Cr-Ni a $1300{ }^{\circ} \mathrm{C}$ [20]..........15

Figura 2.9: Isoterma do diagrama de fases ternário Fe-Cr-Ni a $650{ }^{\circ} \mathrm{C}[20] . . . . . . . . .15$

Figura 2.10: Diagrama pseudobinário 70\%Fe-Cr-Ni. [19] ...................................16

Figura 2.11: Curva tensão x deformação do aço 18Cr-18Mn-0,7N para 4, 77 e $293 \mathrm{~K}$ [35]. Com a redução da temperatura, observa-se um aumento do limite de escoamento e redução da deformação plástica antes da ruptura do material (ductilidade).

Figura 2.12: Energia absorvida no ensaio Charpy em função da temperatura para o aço $18 \mathrm{Cr}-18 \mathrm{Mn}-0,7 \mathrm{~N}$ [35]. O aumento da temperatura aumenta a energia absorvida pelo corpo de prova antes de se fraturar (aumento de sua tenacidade). 23

Figura 2.13: Variação dos valores de CTOD em função da temperatura no metal de base (LT e TL) e de solda (soldagens TIG e por eletrodo revestido) [29]. A componente elástica da deformação permanece praticamente inalterada com a variação da temperatura, ao contrário da componente plástica que aumenta com a temperatura. 
Figura 2.14: Microscopia eletrônica de varredura e EDS dos metais de base e de solda em corpos de prova de CTOD a $-162^{\circ} \mathrm{C}$ : metal de base LT (a), metal de base TL (b), eletrodo revestido (c), TIG (d), EDS de (c) (e) e EDS de (d) (f) [36].

Figura 2.15: Teor de oxigênio no metal de solda em função do índice de basicidade na soldagem por arco submerso de aço carbono [39].

Figura 2.16: Energia de impacto Charpy-V a $-196{ }^{\circ} \mathrm{C}$ para metal de solda $308 \mathrm{~L}$ a arco submerso e soldagens em 316LN realizadas com eletrodos com revestimento básico e de rutilo. [37] 28

Figura 2.17: Efeito do teor de Nitrogênio no ensaio Charpy para material soldado por eletrodo revestido com e sem tratamento térmico de solubilização. [43] .

Figura 2.18: Diagrama de Schaeffler [45], através do qual se pode prever a microestrutura da solda.

Figura 2.19: Diagrama de Schaeffler dividido em diferentes regiões problemáticas durante a soldagem de aços inoxidáveis: formação de trincas de solidificação ou por perda de ductilidade acima de $1250^{\circ} \mathrm{C}$ (1), fragilização por formação de fases intermetálicas após aquecimento entre cerca de $450^{\circ} \mathrm{C}$ e $900^{\circ} \mathrm{C}(2)$, fragilização por crescimento de grão (3), fragilização e fissuração por formação de martensita (4). [23]

Figura 2.20: Modelo de reação de duas fases na poça de fusão. [40] . 37

Figura 2.21: Eletrodeposição de metais em reações catódicas (eletrodo positivo). Adaptado de [49].

Figura 2.22: Reações durante a desoxidação do metal de solda. O gráfico à direita indica o teor de oxigênio para as diferentes faixas de temperaturas ao longo do centro do arco de soldagem. [47] ...........................................................42

Figura 2.23: Soldagem por arco submerso. [52] ..... .44

Figura 2.24: Esquema dos componentes básicos do equipamento de soldagem por arco submerso. [52]

Figura 2.25: Cordão de solda para diferentes polaridades do eletrodo (positiva e negativa). [52].

Figura 2.26: Efeito da velocidade de soldagem na velocidade de solidificação (próximo à linha de centro das soldas) e no formato da poça de fusão na soldagem TIG em CCPD (-). [56]......

Figura 2.27: Regiões criadas pelos ciclos térmicos na soldagem: Zona de ligação, zona fundida e zona afetada pelo calor no metal de base - adaptado de [57]. 
Figura 2.28: Energia livre por unidade de volume $\left(G_{v}\right)$ em função da temperatura (T) para um metal puro - adaptado de [52].

Figura 2.29: Regiões do diagrama ternário Cr-Ni-Fe para 70\% Fe (a) e 60\% Fe (b) (Schafmeister e Ergang, 1939). [61].

Figura 2.30: Morfologias de solidificação da aços inoxidáveis austeníticos: austenita primária com ferrita interdendrítica (a); reação peritética (b) e transformação de ferrita primária a austenita + ferrita abaixo da temperatura solidus (c). [37]. 56 Figura 2.31: Morfologia da ferrita em função da fração volumétrica da mesma. [63] 57 Figura 2.32: Efeito da composição química na morfologia da ferrita e da austenita no diagrama pseudo-binário Fe-Cr-Ni. [30]

Figura 2.33: Microestrutura de solidificação em função da relação ( $\mathrm{Cr} / \mathrm{Ni})$ equiv. [65, $66]$

Figura 2.34: Região de aço inoxidável austenítico com microestrutura do tipo A $(\mathrm{Cr} / \mathrm{Ni})_{\text {eq }}<1,48$ : Apresenta predominância de austenita. A ferrita presente apresenta morfologia eutética. [65]

Figura 2.35: Microestrutura de aço inoxidável austenítico do tipo $\mathrm{C}$ - $(\mathrm{Cr} / \mathrm{Ni})_{\text {eq }}>1,95$ : Apresenta alto teor de ferrita de morfologia acicular. [65]

Figura 2.36: Microestrutura de aço inoxidável austenítico do tipo B - 1,48<(Cr/Ni) $)_{\text {eq }}<$ 1,95 - com alta relação Creq/Nieq: Presença de ferrita acicular cercada por austenita. [41].

Figura 2.37: Microestrutura de aço inoxidável austenítico do tipo B - 1,48<(Cr/Ni) $)_{\text {eq }}<$ 1,95 - com baixa relação Creq/Nieq: Presença de ferrita vermicular em uma matriz austenítica. [41]

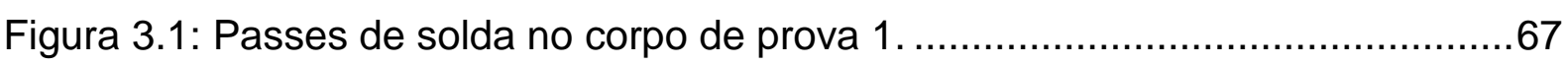

Figura 3.2: Passes de solda no corpo de prova 2. ..........................................68

Figura 3.3: Passes de solda no corpo de prova 3.........................................69

Figura 3.4: Passes de solda no corpo de prova 4 . .................................................70

Figura 3.5: Um dos corpos de prova após o processo de soldagem, com representação das regiões desprezadas nos ensaios (em vermelho) devido a efeitos indesejados como de superfície e instabilidade do arco, e representação de exemplo de região utilizada para ensaio (em azul).

Figura 3.6: Posições em que foram realizadas as medições dos teores de ferrita nos cordões de solda dos quatro corpos de prova. 
Figura 3.7: Direções observadas nas microscopias óptica e eletrônica de varredura nos corpos de prova charpy.

Figura 3.8: Representação do metal de base fundido $(A)$ e do metal de adição $(B)$ no cordão de solda, para cálculo da diluição.

Figura 3.9: Representação do ensaio de dobramento transversal, no qual o corpo de prova é submetido a uma carga aplicada por um cutelo em sua região central (no caso, a zona fundida) e apoiado sobre dois roletes próximos às extremidades [69].76 Figura 3.10: Regiões utilizadas nos corpos de prova dos ensaios Charpy para obtenção das expansões laterais: Região deformada $(A)$ e não deformada $(B)$......77 Figura 4.1: Teores de cromo e de níquel no metal de base e nos metais depositados nos corpos de prova 1 a 4

Figura 4.2: Variação nas concentrações de cromo, níquel, silício, molibdênio e manganês no metal de solda para cada parâmetro de soldagem em relação ao metal de base.

Figura 4.3: Diluição dos cordões de solda para as diferentes condições de soldagem estudadas.

Figura 4.4: Teores médios de nitrogênio e oxigênio no metal de base e na zona fundida dos corpos de prova.

Figura 4.5: Comparação dos teores de enxofre, fósforo e carbono para o metal de base e as quatro condições de soldagem estudadas. 88

Figura 4.6: Variação nas concentrações de carbono, enxofre, fósforo, oxigênio e nitrogênio no metal de solda para cada parâmetro de soldagem em relação ao metal de base.

Figura 4.7: Macrografias dos corpos de prova 1 (a), 2 (b), 3 (c) e 4 (d).................93

Figura 4.8: Pontos de medição das frações volumétricas de ferrita. .94

Figura 4.9: Comparação da fração volumétrica de ferrita em diversas regiões das juntas soldadas dos corpos de prova de 1 a 4.

Figura 4.10: Fração volumétrica média de ferrita nas juntas soldadas dos corpos de prova de 1 a 4.

Figura 4.11: Fractografia de um corpo de prova Charpy $\mathrm{V}$ a $-100^{\circ} \mathrm{C}$ mostrando a clivagem da ferrita e a fratura dúctil da austenita. São apresentadas também as composições químicas das duas regiões. MEV, elétrons secundários. .98 
Figura 4.12: Fotografia sem ataque de uma região fraturada na zona fundida do corpo de prova 3 Charpy V, mostrando a presença de inclusões. Microscópio óptico.

Figura 4.13: Relação $\mathrm{Cr}_{\text {eq }} / \mathrm{Ni}_{\text {eq }}$ para as diferentes condições de soldagem. 101

Figura 4.14: Micrografia do cordão de solda na qual se observam as morfologias da ferrita para o corpo de prova $3(\mathrm{CC} / \mathrm{L})$. Ataque eletrolítico, ácido oxálico $10 \%$. Microscópio óptico. 102

Figura 4.15: Micrografia do cordão de solda mostrando as morfologias da ferrita e a presença de uma micro inclusão de escória. Ataque eletrolítico, ácido oxálico 10\%. Microscópio óptico. 103

Figura 4.16: Transição de microestruturas na zona fundida do corpo de prova 4. $\mathrm{MEV}$, elétrons secundários. 104

Figura 4.17: Corpos de prova após ensaio de dobramento transversal. 106

Figura 4.18: Relação entre tamanho médio do alvéolo e teor de oxigênio no metal de solda. 109

Figura 4.19: Mecanismo de fratura para ferrita vermicular (a) e acicular (b) a temperatura baixa ou criogênica: Ocorre nucleação e crescimento de alvéolos em inclusões na austenita. A ferrita vermicular cliva, enquanto a ferrrita acicular não. [32]

Figura 4.20: Propagação da trinca nos corpos de prova $1(\mathrm{CA} / \mathrm{N})(\mathrm{a})$ e $2(\mathrm{CC} / \mathrm{N})(\mathrm{b})$, soldados com fluxo neutro. Observa-se formação de trincas secundárias. Microscópio óptico.

Figura 4.21: Propagação da trinca nos corpos de prova $3(\mathrm{CC} / \mathrm{L})$ (a) e $4(\mathrm{CC} / \mathrm{N})(\mathrm{b})$, soldados com fluxo ligado. No corpo de prova 3 (CC/L) a propagação da trinca é mais linear que nos demais corpos de prova. Para o corpo de prova $4(C C / N)$, observam-se trincas secundárias. Microscópio óptico.

Figura 4.22: Propagação de trinca no corpo de prova $3(\mathrm{CC} / \mathrm{L})$, em baixo aumento (a) e alto aumento (b). Microscópio óptico. 118

Figura 4.23: Fratura acompanha a morfologia da ferrita e de inclusões. Microscópio óptico.

Figura 4.24: Superfície de fratura do corpo de prova 1 (CA/N). Observa-se uma superfície irregular, que indica mudanças de direção durante a propagação da trinca, necessitando maior energia. Microscópio eletrônico de varredura, elétrons secundários. 
Figura 4.25: Superfície de fratura do corpo de prova $2(\mathrm{CC} / \mathrm{N})$. A superfície de fratura é irregular, novamente indicando mudanças de direção durante a propagação da trinca que requerem maior energia para o material fraturar. Microscópio eletrônico de varredura, elétrons secundários. 120

Figura 4.26: Superfície de fratura do corpo de prova 3 (CC/L) (raiz). A superfície apresenta grandes regiões planas, indicando menor quantidade de mudanças de direção e, consequentemente, absorvendo menos energia durante a propagação da trinca. Microscópio eletrônico de varredura, elétrons secundários. 121

Figura 4.27: Superfície de fratura do corpo de prova 3 (CC/L) (face). A superfície fraturada apresenta grandes regiões planas. Microscópio eletrônico de varredura, elétrons secundários.

Figura 4.28: Superfície de fratura do corpo de prova $2(\mathrm{CC} / \mathrm{N})$. As regiões austeníticas possuem alvéolos dúcteis em sua microestrutura, e regiões que ferríticas apresentam fratura por clivagem em um plano distinto. Microscópio eletrônico de varredura, elétrons secundários. 123

Figura 4.29: Inclusões no corpo de prova 3 (CC/L). Microscópio eletrônico de varredura.

Figura B.1: Expansão lateral em função da energia absorvida nas regiões dos passes de solda da face e da raiz para o corpo de prova 1 (CA/N). 139

Figura B.2: Expansão lateral em função da energia absorvida nas regiões dos passes de solda da face e da raiz para o corpo de prova 2 (CC/N). 140

Figura B.3: Expansão lateral em função da energia absorvida nas regiões dos passes de solda da face e da raiz para o corpo de prova $3(\mathrm{CC} / \mathrm{L})$. 140

Figura B.4: Expansão lateral em função da energia absorvida nas regiões dos passes de solda da face e da raiz para o corpo de prova 4 (CA/L). 141

Figura B.5: Expansão lateral em função da energia absorvida para os quatro corpos de prova nas regiões dos passes de solda da raiz

Figura B.6: Expansão lateral em função da energia absorvida para os quatro corpos de prova nas regiões dos passes de solda da face. 


\section{Índice de Tabelas}

Tabela 2.1: Pontos de ebulição de diferentes gases atmosféricos na temperatura absoluta e em graus Celsius à pressão de $1 \mathrm{~atm}$. Adaptado de [1].

Tabela 2.2: Efeitos do aumento da temperatura em aços inoxidáveis austeníticos. .24 Tabela 2.3: Efeitos de diferentes elementos de liga nas propriedades mecânicas de aços inoxidáveis austeníticos a baixas temperaturas.

Tabela 2.4: Vantagens e desvantagens da presença de ferrita durante a soldagem de aços inoxidáveis austeníticos para utilização a baixas temperaturas. .33

Tabela 2.5: Modos de solidificação em diferentes velocidades na soldagem TIG. Adaptado de [56].

Tabela 3.1: Composição química da chapa de aço AISI 304 utilizado na soldagem.65

Tabela 3.2: Composição química do arame ER 308L utilizado na soldagem. .66

Tabela 3.3: Composição química do fluxo neutro ME. 66

Tabela 3.4: Parâmetros de soldagem do corpo de prova 1

Tabela 3.5: Parâmetros de soldagem do corpo de prova 2. 68

Tabela 3.6: Parâmetros de soldagem do corpo de prova 3. 69

Tabela 3.7: Parâmetros de soldagem do corpo de prova 4. .70

Tabela 4.1: Teores de diversos elementos nos metais depositados dos corpos de prova 1, 2, 3 e 4 . 79

Tabela 4.2: Concentração de diversos elementos no corpo de prova 1 (CA/N) ........81

Tabela 4.3: Concentração de diversos elementos no corpo de prova $2(\mathrm{CC} / \mathrm{N})$. ......81

Tabela 4.4: Concentração de diversos elementos no corpo de prova 3 (CC/L) ........82

Tabela 4.5: Concentração de diversos elementos no corpo de prova 4 (CA/L) . .......82

Tabela 4.6: Teores de oxigênio nos corpos de prova 1 a 4 e do metal de base. ......85

Tabela 4.7: Teores de nitrogênio nos corpos de prova 1 a 4 e do metal de base.....86 Tabela 4.8: Teores de Nieq e Creq para os corpos de prova 1, 2, 3 e 4 através do cálculo usual do metal de base, da zona fundida e do metal de adição (arame); e através do cálculo proposto por Hammar e Svenson apenas da zona fundida. 91

Tabela 4.9: Valores de $\mathrm{Cr}_{\text {eq }}$, $\mathrm{Ni}_{\text {eq }}$ e $\mathrm{Cr}_{\text {eq }} / \mathrm{Ni}_{\text {eq }}$ para os metais depositados nos corpos de prova de 1 a 4.

Tabela 4.10: Fração volumétrica de ferrita nas juntas dos corpos de prova 1, 2, 3 e 4. 
Tabela 4.11: Relações $\mathrm{Cr}_{\text {eq }} / \mathrm{Ni}_{\text {eq }}$ e morfologias de ferrita previstas para os corpos de prova de 1 a 4 através do cálculo usual e pelo cálculo proposto por Hammar e Svenson.

Tabela 4.12: Elementos nas microestruturas das diferentes regiões da zona fundida do corpo de prova 4.

Tabela 4.13: Níquel e cromo equivalentes para as duas regiões de morfologias distintas na zona fundida do corpo de prova 4. 105

Tabela 4.14: Dados dos ensaios de dobramento lateralpara os corpos de prova 1 a 4.

Tabela 4.15: Dados dos ensaios de tração para os corpos de prova 1 a 4 108

Tabela 4.16: Resultados dos ensaios Charpy V a $-100^{\circ} \mathrm{C}$ 110

Tabela 4.17: Comparação estatística a um nível de significância de 1\% entre as energias absorvidas e expansões laterais médias entre as soldas realizadas com correntes iguais. Desta forma, observa-se a influência do fluxo sobre os resultados dos ensaios Charpy.

Tabela 4.18: Comparação estatística a um nível de significância de 1\% entre as energias absorvidas e expansões laterais médias entre as soldas realizadas com correntes iguais, de maneira a verificar a influência do tipo de corrente utilizado na soldagem sobre os resultados dos ensaios Charpy.

Tabela 4.19: Resultados da análise por EDS de inclusões no corpo de prova 3 (CC/L). 125

Tabela 4.20: Raios médios dos alvéolos para os corpos de prova de 1 a 4. 126

Tabela A.1: Valores de $Z_{\text {calc }}$ e $Z_{\text {crít }}$ na comparação entre as médias de energias absorvidas na superfície e na raiz.

Tabela A.2: Valores de $Z_{\text {calc }}$ e $Z_{\text {crít }}$ na comparação entre as médias de energias absorvidas para mesmos tipos de corrente.

Tabela A.3: Valores de $Z_{\text {calc }}$ e $Z_{\text {crít }}$ na comparação entre as médias de energias absorvidas para mesmos tipos de fluxo.

Tabela A.4: Valores de $Z_{\text {calc }}$ e $Z_{\text {crít }}$ na comparação entre as expansões laterais para mesmos tipos de corrente.

Tabela A.5: Valores de $Z_{\text {calc }}$ e $Z_{\text {crít }}$ na comparação entre as expansões laterais para mesmos tipos de fluxo. 


\section{Lista de Símbolos}

Símbolo

Descrição

$\Delta \rho \quad$ Diferença ente densidade do aço fundido e das inclusões

dl Elemento de linha no contorno

$d_{p} \quad$ Diâmetro da partícula

E Energia térmica média

g Constante gravitacional

$\mathrm{G}_{\mathrm{V}} \quad$ Energia livre por unidade de volume

$\mathrm{J} \quad$ Integral de contorno

K Fator concentrador de tensão

$\mathrm{K}_{\mathrm{IC}} \quad$ Fator de tensão crítico

L Líquido

m Média

n Valência

$\mathrm{P}_{\mathrm{O} 2} \quad$ Pressão parcial de oxigênio

R Velocidade média de solidificação local

s Desvio padrão

T Temperatura

TS Temperatura de solidificação

u Vetor deslocamento

$\mathrm{w}_{\mathrm{el}} \quad$ Densidade de energia elástica

$\mathrm{Z}_{\text {calc }} \quad \mathrm{Z}$ calculado

$Z_{\text {crit }} \quad Z$ crítico

y Austenita

$\delta \quad$ Deformação

$\delta \quad$ Ferrita

$\eta \quad$ Viscosidade do aço

$\theta$ Ângulo entre direção de soldagem e direção de crescimento das dendritas

$\lambda \quad$ Constante adimensional

$\mathrm{v} \quad$ Velocidade de soldagem

$\sigma_{y} \quad$ Limite de escoamento 
$\Gamma \quad$ Face da trinca

V Velocidade média de ascensão de partículas 


\section{Sumário}

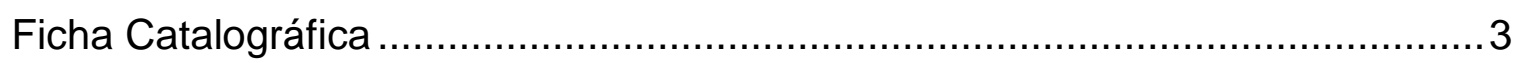

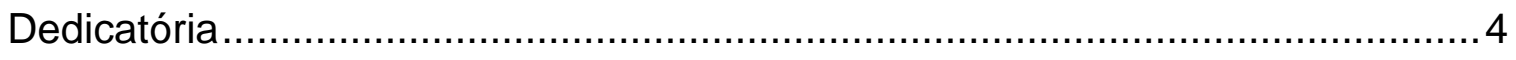

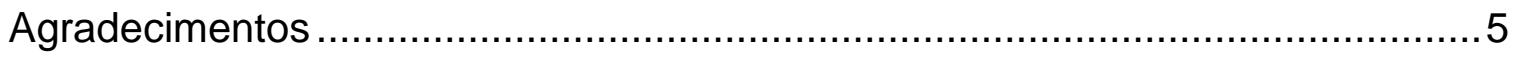

Resumo

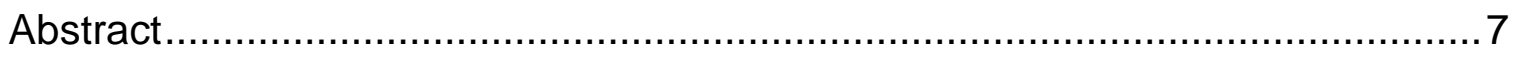

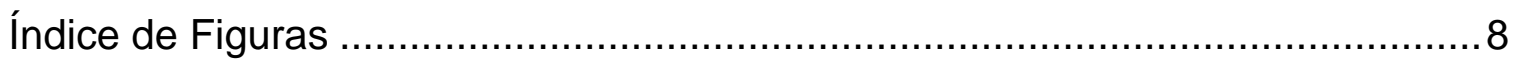

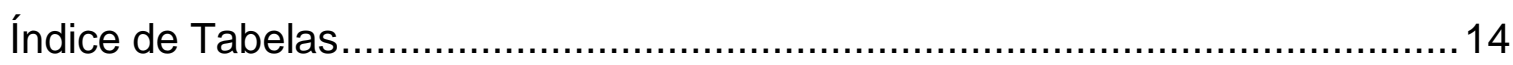

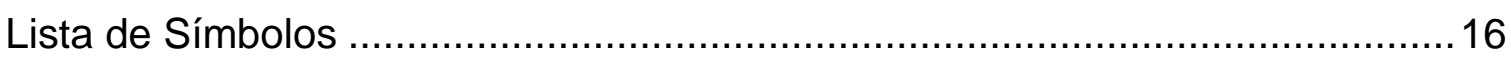

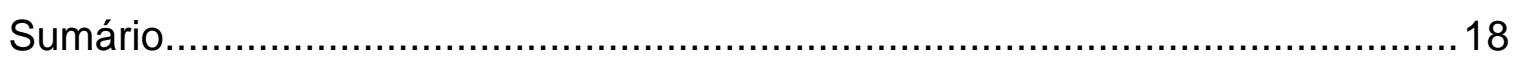

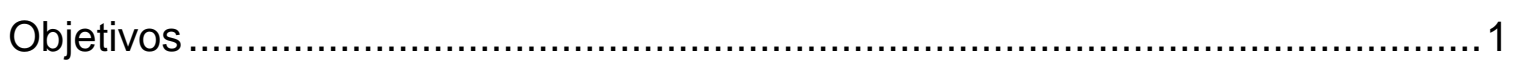

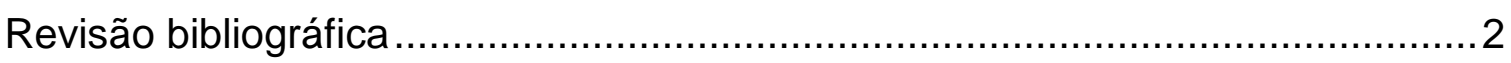

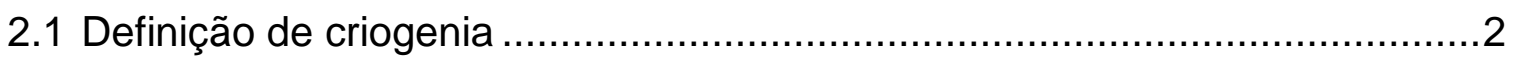

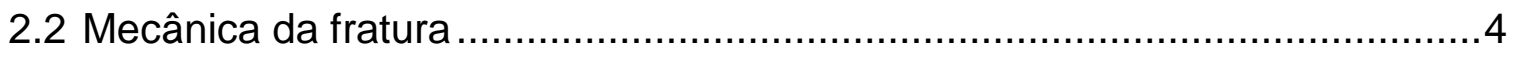

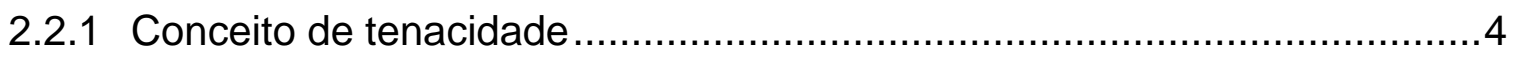

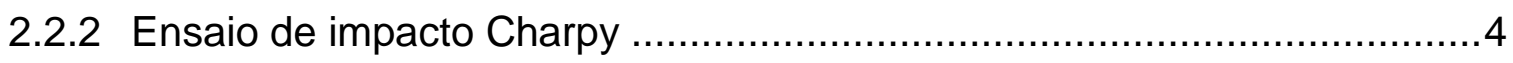

2.2.3 Tenacidade à fratura na deformação plana ............................................

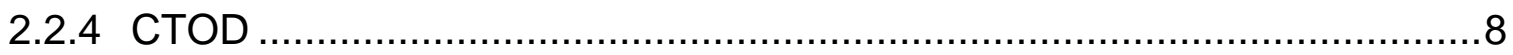

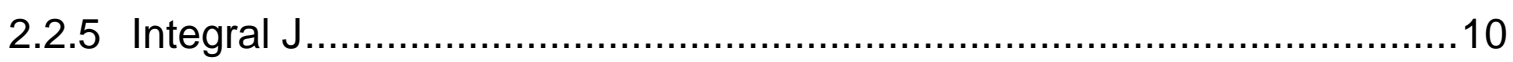

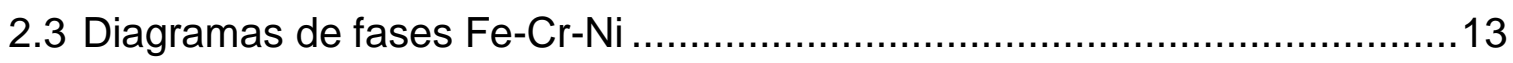

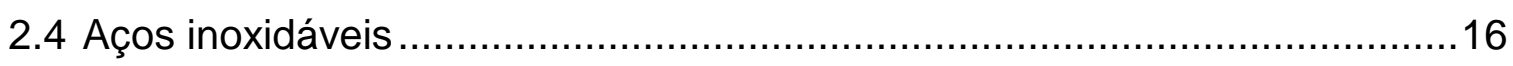

2.4.1 Aços Inoxidáveis martensíticos ..........................................................17

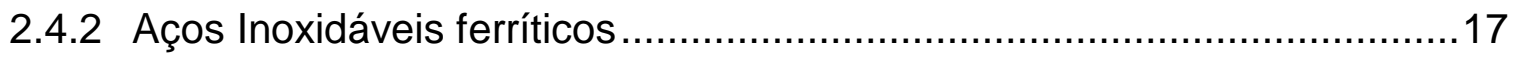

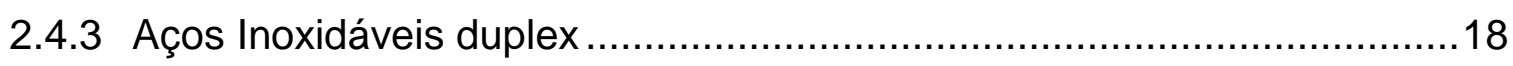

2.4.4 Aços Inoxidáveis endurecidos por precipitação (envelhecidos) ...............18 
2.4.6 Microestrutura e propriedades mecânicas......................................20

2.4.7 Soldagem de aços inoxidáveis austeníticos ....................................30

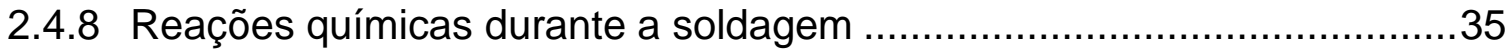

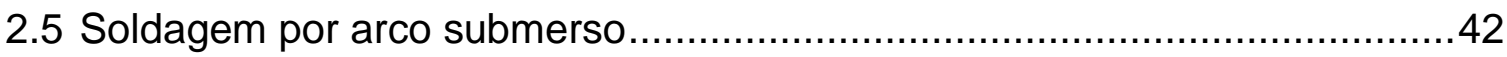

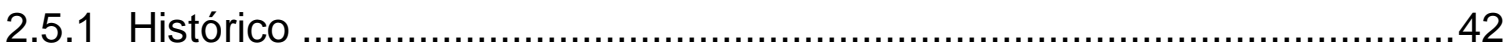

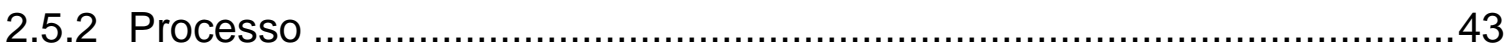

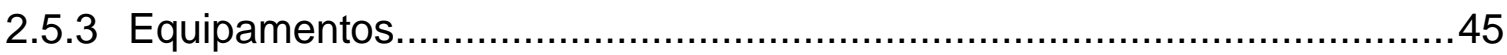

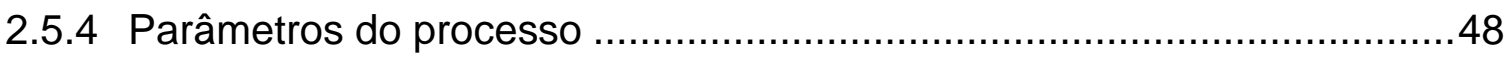

2.5.5 Solidificação da poça de fusão ..................................................... 52

2.5.6 Solidificação de aços inoxidáveis austeníticos ..................................54

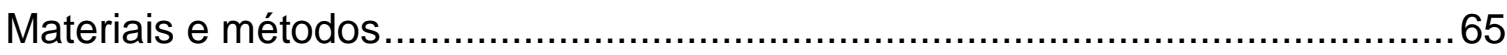

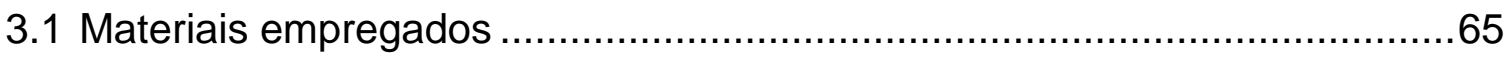

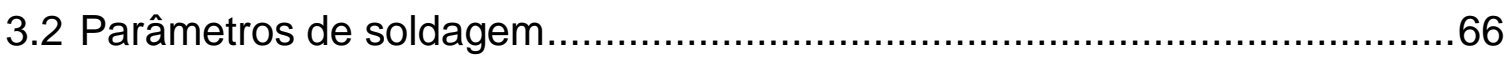

3.3 Ensaios realizados na junta soldada .............................................. 71

3.3.1 Composição química................................................................. 71

3.3.2 Caracterização microestrutural...................................................... 72

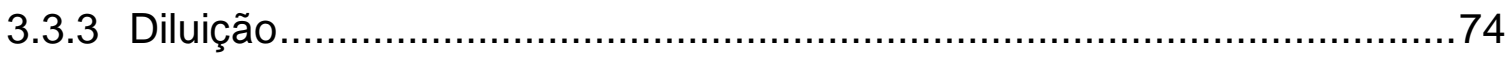

3.3.4 Propriedades mecânicas. .............................................................. 75

3.4 Análise estatística........................................................................ 77

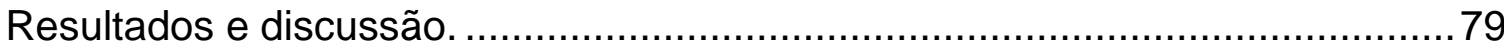

4.1 Análise química. ........................................................................ 79

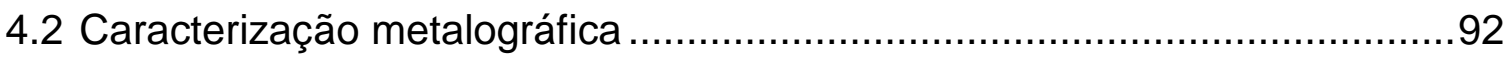

4.2.1 Macrografias dos cordões de solda............................................92 
4.2.2 Medida da fração volumétrica de ferrita delta.....................................93

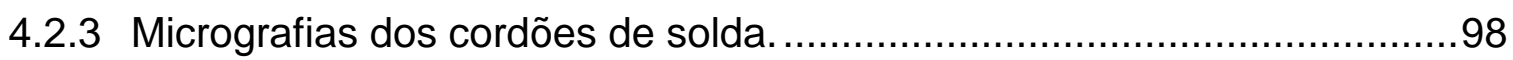

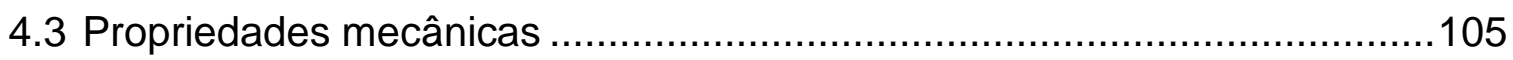

4.3.1 Ensaio de dobramento lateral da junta soldada .............................106

4.3.2 Ensaio de tração da junta soldada .............................................. 107

4.3.3 Ensaio de impacto (Charpy V) de regiões da junta soldada...................109

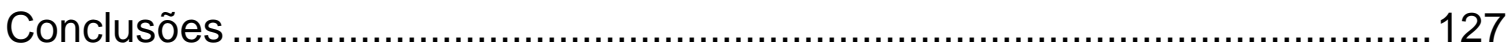

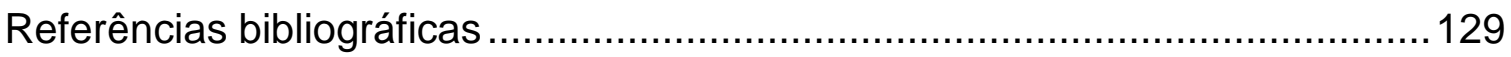

ANEXO A - Resultados estatísticos dos ensaios Charpy............................137

ANEXO B - Relação entre expansão lateral e energia absorvida nos ensaios

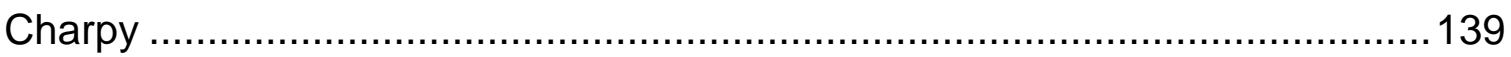




\section{Objetivos}

Verificar as diferenças nas propriedades mecânicas a baixas temperaturas e nas microestruturas de um aço inoxidável AISI 304 decorrentes das alterações nos parâmetros da soldagem por arco submerso, utilizando-se dois tipos de fluxos (fluxo neutro e fluxo auto-compensante em cromo) e dois tipos de corrente distintos (corrente contínua e corrente alternada de onda quadrada). 


\section{Revisão bibliográfica}

\subsection{Definição de criogenia}

Criogenia pode ser definida como: a ciência e tecnologia de temperaturas abaixo de $120 \mathrm{~K}\left(-153^{\circ} \mathrm{C}\right)$, ou como a ramificação da física que estuda a produção de temperaturas muito baixas e seus efeitos. A temperatura limite de $120 \mathrm{~K}\left(-153^{\circ} \mathrm{C}\right)$, foi definida com base nos pontos de ebulição normais dos principais gases atmosféricos, conforme mostra a tabela 2.1, bem como do metano, que é o principal componente do gás natural [1].

Tabela 2.1: Pontos de ebulição de diferentes gases atmosféricos na temperatura absoluta e em graus Celsius à pressão de $1 \mathrm{~atm}$. Adaptado de [1].

\begin{tabular}{|c|c|c|}
\hline \multirow{2}{*}{ Gás } & \multicolumn{2}{|c|}{ Ponto de ebulição normal } \\
\cline { 2 - 3 } & $(\mathbf{K})$ & $\left.{ }^{\circ} \mathbf{C}\right)$ \\
\hline Metano & 111,6 & $-161,4$ \\
\hline Oxigênio & 90,2 & $-182,8$ \\
\hline Argônio & 87,3 & $-185,7$ \\
\hline Nitrogênio & 77,3 & $-195,7$ \\
\hline Neon & 27,1 & $-245,9$ \\
\hline Hidrogênio & 20,4 & $-259,6$ \\
\hline Hélio & 4,2 & $-268,8$ \\
\hline
\end{tabular}

Existe uma faixa de temperatura, que também é bastante utilizada na indústria química e petroquímica, que não se enquadra dentro da definição de criogenia. São temperaturas de projeto de equipamentos por volta de $-100^{\circ} \mathrm{C}$, que também é uma temperatura baixa, porém acima da temperatura de definição da criogenia $\left(-153^{\circ} \mathrm{C}\right)$. Esta temperatura de projeto é empregada em torres de destilação fracionada para 
obtenção e separação dos compostos presentes no gás natural liquefeito, sendo esta a temperatura deste estudo.

Através da equação (1) desenvolvida por Boltzmann, que relaciona a energia térmica média $\mathrm{E}$ de uma partícula em um sistema em equilíbrio à temperatura $\mathrm{T}$ e a uma constante $\mathrm{k}_{\mathrm{B}}=1,38.10^{-23} \mathrm{~J} / \mathrm{K}$, nota-se que uma temperatura de $1 \mathrm{~K}$ equivale a uma energia térmica de $10^{-4} \mathrm{eV}$ ou $10^{-23} \mathrm{~J}$ por partícula. Desta forma, uma temperatura é considerada baixa, para um dado processo físico, quando o produto $\left(k_{B} . T\right)$ é baixo em relação à energia característica do processo considerado. Assim, temperaturas criogênicas são definidas como fenômenos com baixa energia característica.

$$
\mathrm{E} \sim \mathrm{k}_{\mathrm{B}} \cdot \mathrm{T}
$$

Segundo Lebrun [2], a criogenia surgiu na busca da liquefação dos gases da atmosfera ditos até então incondensáveis. Em 1877, L. Cailletet e R. Pictet realizaram a primeira liquefação de ar, e em 1883, K. Olszewski e S. Wroblewski separaram o oxigênio do nitrogênio. $O$ surgimento da criogenia propriamente dita ocorreu apenas no ano de 1908, quando H. Kamrelingh Onnes realizou a primeira liquefação de hélio. A partir de então teve início o estudo de condensados a baixas temperaturas, levando ao descobrimento de fenômenos tais como a supercondutividade e os superfluidos. Tais fenômenos só foram explicados pela mecânica quântica na segunda metade do século XX. Por mais que o potencial de aplicação destes fenômenos tenha sido rapidamente identificado, apenas no início da década de 1960 que a supercondutividade e a superfluidez se tornaram técnicas industriais.

Uma grande aplicação da criogenia é na densificação, liquefação e separação por destilação de gases e misturas gasosas, tais como oxigênio e nitrogênio utilizados em processos químicos e metalúrgicos, bem como propulsores sólidos de foguetes e também na possível utilização de hidrogênio como combustível.

Conforme exposto anteriormente, a supercondutividade só foi possível com a criogenia. $\mathrm{Na}$ indústria, a supercondutividade tem sua aplicação em sistemas de ressonância magnética nuclear, equipamentos de fusão por confinamento magnético 
e aceleradores de partículas de alta energia. Atualmente estão em desenvolvimento os supercondutores de alta temperatura, que eventualmente substituirão os supercondutores atuais em alguns nichos devido a sua maior facilidade de operação, uma vez que estes operam à temperatura de nitrogênio líquido (63 K), enquanto os materiais atuais requerem criogenia de baixa temperatura (em geral 20 $\mathrm{K}$ ou hélio liquefeito).

Temperaturas criogênicas também têm aplicação na preservação de células biológicas, uma vez que a cinética das reações químicas varia exponencialmente na equação de Arrhenius. Desta forma, a cinética pode ser efetivamente bloqueada quando a temperatura absoluta se torna menor que sua energia de ativação.

\subsection{Mecânica da fratura}

\subsubsection{Conceito de tenacidade}

Tenacidade pode ser definida como a capacidade de um material de absorver energia [3] na deformação plástica e fratura. Ela é geralmente caracterizada pela área sob uma curva tensão versus deformação de um corpo de prova lentamente deformado até a fratura, embora esta não seja a condição ideal para avaliar a tenacidade.

\subsubsection{Ensaio de impacto Charpy}

Para a determinação da quantidade de energia absorvida no ensaio de impacto com a presença de entalhes, utilizam-se métodos como o ensaio Charpy, onde um pêndulo com uma dada energia parte de uma altura inicial, atinge o corpo de prova, 
causa a sua fratura e atinge uma altura máxima, com a qual se mede a diferença entre a energia inicial e a energia dissipada para que ocorra a falha. Quanto menor a altura máxima final, maior a tenacidade do material neste ensaio.

No ensaio Charpy, o corpo de prova possui um entalhe e sofre uma alta taxa de deformação no momento da fratura, pois o material deve absorver o impacto do pêndulo, e o teste é realizado em uma faixa de diferentes temperaturas [4]. O corpo de prova pode ter diferentes tipos e dimensões dos entalhes, de acordo com a norma ASTM E23 [5], como se observa na figura 2.1.

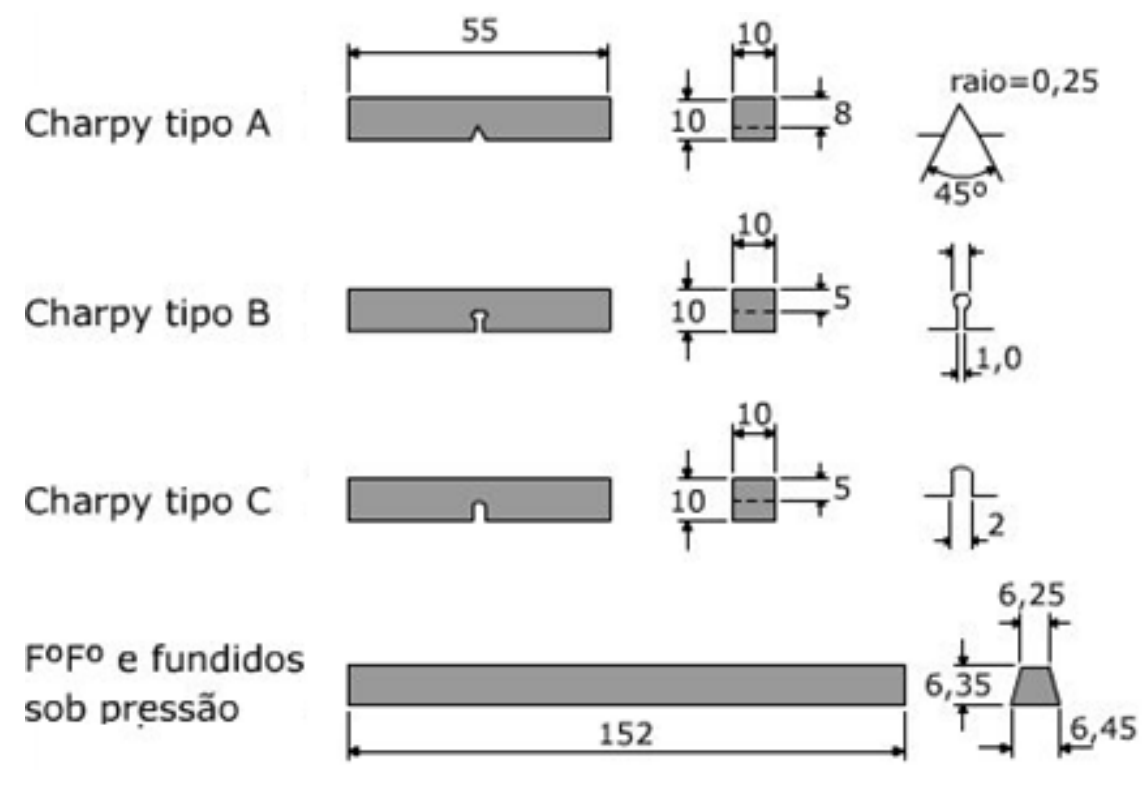

Todas as dimensões em mm

Figura 2.1: Dimensões para os corpos de prova e dos entalhes para o ensaio de impacto tipo Charpy, segundo a norma ASTM E23 [5].

Na figura 2.2 observa-se que, conforme a temperatura em que o material é ensaiado diminui, menor é a energia absorvida pelo corpo de prova. Em outras palavras, um aço carbono em temperaturas ao redor da temperatura ambiente é tenaz e quando rompe, o aspecto da fratura é tipicamente dúctil. Quanto menor a temperatura, maior a tendência do material apresentar uma fratura tipicamente frágil. Isto significa que existe uma temperatura onde ocorre a transição frágil-dúctil do material em análise. Esta temperatura pode ser estimada de diferentes maneiras [4] 
como: energia absorvida no ensaio de impacto, porcentagem de fratura frágil da superfície do corpo-de-prova, expansão lateral mínima, etc.

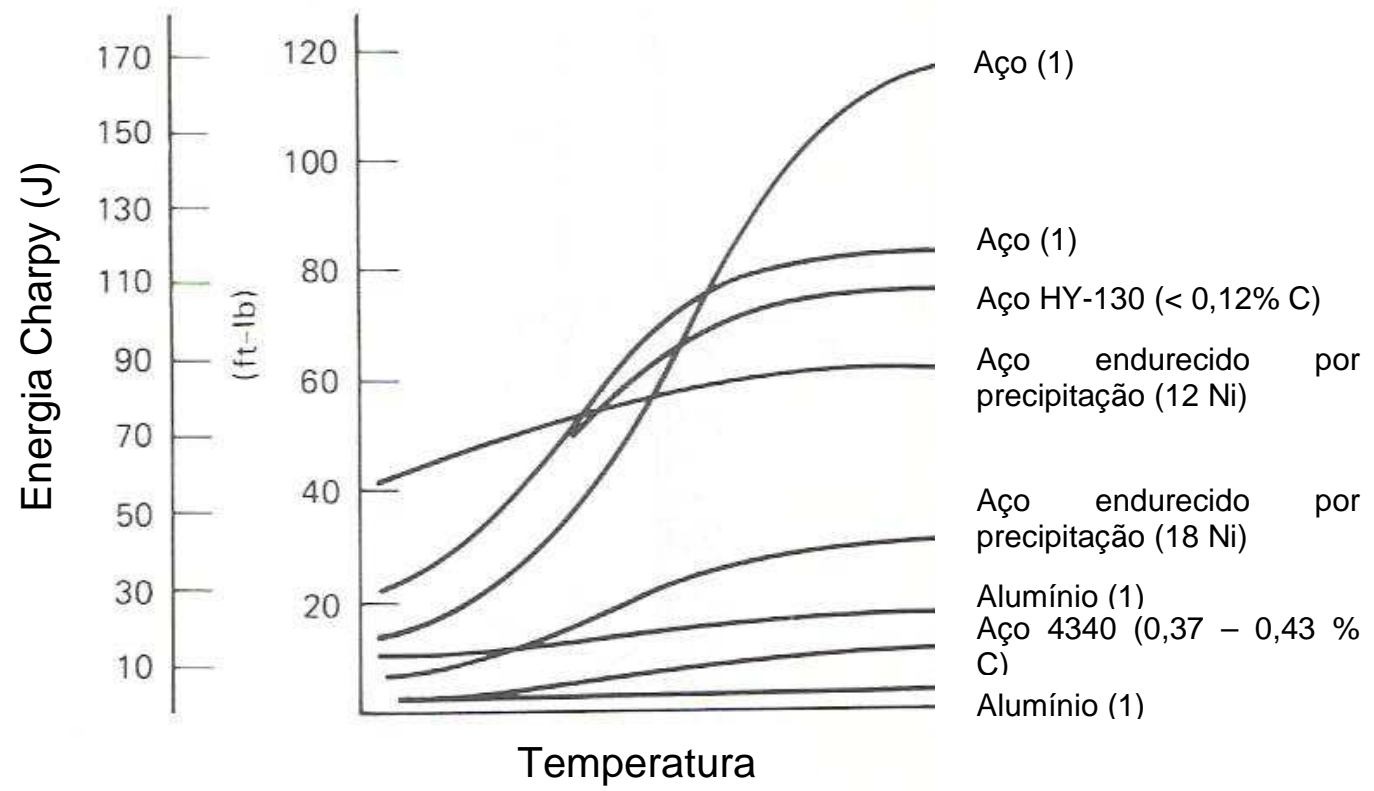

Figura 2.2: Variação de resultados no ensaio Charpy para diferentes temperaturas em diversos materiais metálicos. Adaptado de [4].

(1) Não foi informado na referência nenhum dado adicional em relação a estes materiais.

Quando metais são deformados plasticamente, uma fração da energia é retida internamente, sendo o restante dissipado na forma de calor [7]. A maior porção da fração retida internamente está associada à movimentação das discordâncias.

As discordâncias não se movem com a mesma facilidade em todos os planos cristalográficos dos átomos, nem em todas as direções cristalográficas, havendo uma família de planos preferenciais denominados "planos de escorregamento" e uma família de direções preferenciais chamadas de "direções de escorregamento" [7]. A discordância move-se, então, em um sistema de escorregamento, que é o conjunto das famílias das direções e planos de escorregamento. Geralmente, a família de planos e direções de escorregamento são os que possuem a maior densidade de empacotamento atômico. Além do escorregamento, a deformação plástica em materiais metálicos também pode ocorrer pela formação de maclas 
mecânicas, fenômeno denominado maclação. Este último mecanismo ocorre para elevadas taxas de deformação e/ou temperaturas baixas.

A resistência à fratura dos materiais foi inicialmente estudada por Griffith [8] em 1951, sendo definida como uma propriedade que descreve a capacidade de um material, contendo uma trinca, de resistir à fratura [9]. Para a fratura frágil, a resistência é comumente medida como um dado valor, por exemplo pela temperatura de transição dúctil-frágil obtida através do ensaio de impacto em diferentes temperaturas, ou caracterizada pelo fator concentrador de tensão K, que é utilizado para materiais linearmente elásticos, através do ensaio de tenacidade a fratura. Para a fratura dúctil, a resistência pode ser medida como um dado valor ou no formato de uma curva de resistência comumente caracterizada pela integral $\mathrm{J}$, que é usada para materiais elasto-plásticos.

Outro parâmetro importante da mecânica da fratura elasto-plástica, denominado CTOD ("Crack-tip opening displacement" ou abertura de ponta da trinca) foi proposto por Wells [10] em 1965 após a análise de corpos de prova de aços de alta tenacidade fraturados. Dois fatos foram observados:

- As condições não se aplicavam à mecânica da fratura elástica;

- As superfícies das trincas se separaram, e a ponta da trinca adquiriu um raio de curvatura significativo.

Com isto, Wells propôs que este arredondamento fosse utilizado como critério de tenacidade de materiais dúcteis, que é indicado especialmente para materiais que apresentam mudança de comportamento (transição dúctil-frágil) com o decréscimo da temperatura. A tenacidade pode ser avaliada através de diferentes conceitos, que serão descritos a seguir.

\subsubsection{Tenacidade à fratura na deformação plana}

A tenacidade à fratura é uma propriedade do sistema representada por $\mathrm{K}_{\mathrm{c}}$, e quando medida no estado plano de deformação, é simbolizada por $K_{I C}$ [11]. Segundo 
Rossoll [12], $\mathrm{K}_{\mathrm{Ic}}$ é definido como o fator de intensificação de tensão crítico e denota a resistência de um material à propagação de uma trinca previamente existente.

$O \mathrm{~K}_{\mathrm{lc}}$ é definido como o fator de tensão crítica e denota a resistência de um material à propagação de uma trinca previamente existente [12]. A tenacidade à fratura corresponde ao módulo de coesão introduzido por Barenblatt [11]. Entretanto, é conveniente manter a denominação acima tendo em vista que ela é amplamente disseminada na engenharia e que ela admite uma influência do estado de tensão sobre esta propriedade (não admitida por Barenblatt).

O $\mathrm{K}_{\mathrm{lc}}$ é uma propriedade intrínseca do material, ou seja, não depende da geometria do componente; já $\mathrm{K}_{\mathrm{c}}$, quando medida fora do estado plano de deformação, dependerá da geometria do sistema e do material. $K_{c}$ varia linearmente com a espessura da placa no estado plano de tensão [13].

\subsubsection{CTOD}

A princípio o CTOD possuía um caráter empírico, porém mais tarde foi relacionado ao $\mathrm{K}$ no limite de plasticidade utilizando as fórmulas de Irwin, obtendose:

$$
C T O D=\delta=\frac{4}{\pi} \frac{K^{2}}{\sigma_{e} E}
$$

Para a equação acima, a fratura ocorre quando $\mathrm{K} \geq \mathrm{K}_{\mathrm{lc}} \rightarrow \delta \geq \delta_{\mathrm{lc}}$. Através do modelo de Dugdaale-Baremblatt, obtém-se a expressão:

$$
C T O D=\delta=\frac{K^{2}}{\sigma_{e} E}
$$

As expressões (2.2) e (2.3) assumem o estado plano de tensão e um material que não sofre encruamento. Generalizando, temos: 


$$
\delta=\frac{K^{2}}{\lambda \sigma_{e} E}
$$

Onde:

$\lambda$ é uma constante adimensional. Quando o estado plano de tensão é predominante, $\lambda \sim 1,0$; quando o estado plano de deformação é predominante, $\lambda \sim$ 2,0 .

Existe uma relação entre CTOD e a integral J, confirmando assim a hipótese de Wells de que este parâmetro caracteriza a resistência ao crescimento de trincas em materiais dúcteis.

Inicialmente, tentou-se medir diretamente CTOD, mas sem sucesso. O procedimento adotado atualmente envolve a medição da abertura da boca da trinca ou COD (“Crack Opening Displacement”, $\Delta$ ). O valor de CTOD é então estimado em função de COD. Para corpos de prova solicitados em flexão de três pontos (figura 2.3):

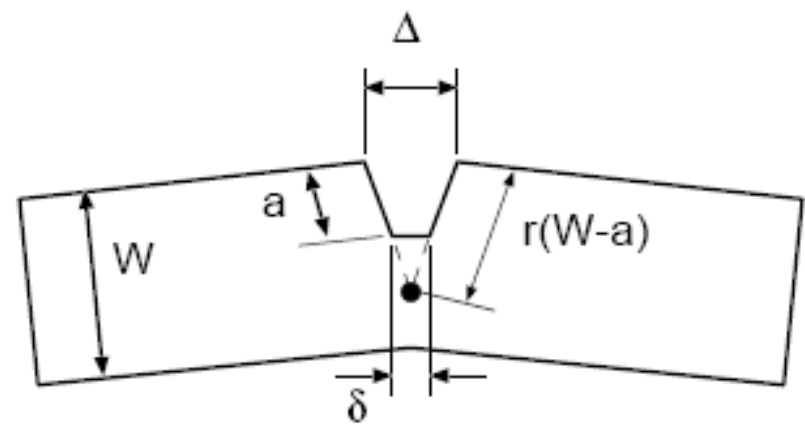

Figura 2.3: Representação esquemática do método para estimar CTOD a partir de medidas de $\operatorname{COD}[11]$.

Por semelhança de triângulos, tem-se:

$$
\delta=\frac{r(W-a) \Delta}{r(W-a)+a} \quad(0 \leq r \leq 1)
$$

O procedimento experimental estabelece que a fórmula anterior seja aplicada apenas à parcela plástica da abertura da ponta da trinca (figura 2.4). A relação entre COD e CTOD será, portanto: 


$$
\delta=\delta_{e}+\delta_{p l}=\frac{K_{C}^{2}}{\lambda \sigma_{e} E}+\frac{r_{p l}(W-a) \Delta_{p l}}{r_{p l}(W-a)+a}
$$

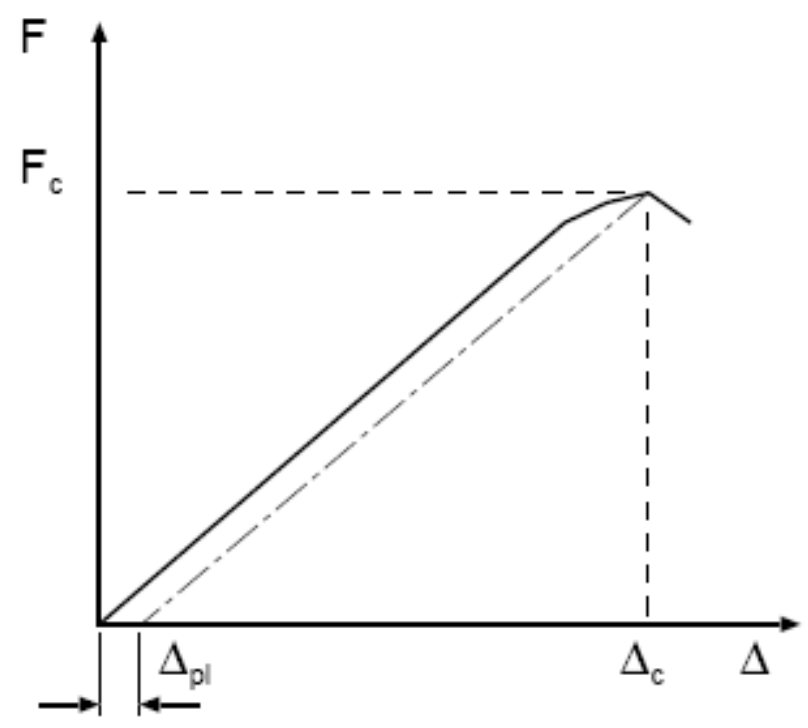

Figura 2.4: Curva da carga em função do deslocamento, típica de um ensaio de CTOD. [11]

Através do CTOD, é possível expandir o escopo da mecânica da fratura para casos os quais envolvam plasticidade ilimitada, porém nestes casos $\delta$ não será uma propriedade intrínseca do material (dependerá da espessura do metal e da geometria do sistema).

\subsubsection{Integral J}

Segundo Silva [6], a integral J é definida como uma integral de contorno, pressupondo comportamento linear ou não linear da deformação.

Geralmente uma curva de resistência baseada na integral $J$ é utilizada para descrever a resistência de um material dúctil ao início de formação de uma trinca, seu crescimento estável e instabilidade da ruptura [9]. Devido à sua eficácia em medir a resistência, a integral $\mathrm{J}$ e a curva $\mathrm{J}-\mathrm{R}$ se tornaram os parâmetros mais importantes dos materiais na mecânica da fratura elasto-plástica, e têm sido amplamente aplicadas na engenharia. Tais valores de resistência à fratura podem servir como base para caracterização de um material, avaliação de performance e garantia de qualidade. Elas também podem ser utilizadas para avaliar a tolerância a 
danos estruturais, analisar tensões residuais e no gerenciamento de integridade estrutural de diversos componentes de engenharia e estruturas.

A integral J foi introduzida inicialmente por Eshelby [14] em 1951 no estudo de discordâncias e aplicado independentemente por Cherepanov [15] (1967) e Rice [16] (1968) para a investigação da propagação de trincas em materiais dúcteis. Através do princípio da conservação de energia, Eshelby demonstrou que para um elemento elástico não linear, a integral de linha sobre o contorno $\Gamma$, definida por:

$$
J=\int_{\Gamma}\left(w_{e i} d x_{2}-T \frac{\partial u}{\partial x_{1}} d l\right)
$$

Onde $w_{\mathrm{el}}=\int \sigma_{\mathrm{ij}} \mathrm{d} \varepsilon_{\mathrm{ij}}$ é a densidade de energia elástica, $T$ é o vetor tração normal, atuando no sentido exterior ao contorno, u é o vetor deslocamento (já introduzido anteriormente) e dl é um elemento de linha no contorno, é independente do caminho (ou seja, ela se anula se o contorno for fechado, conforme a figura 2.5).

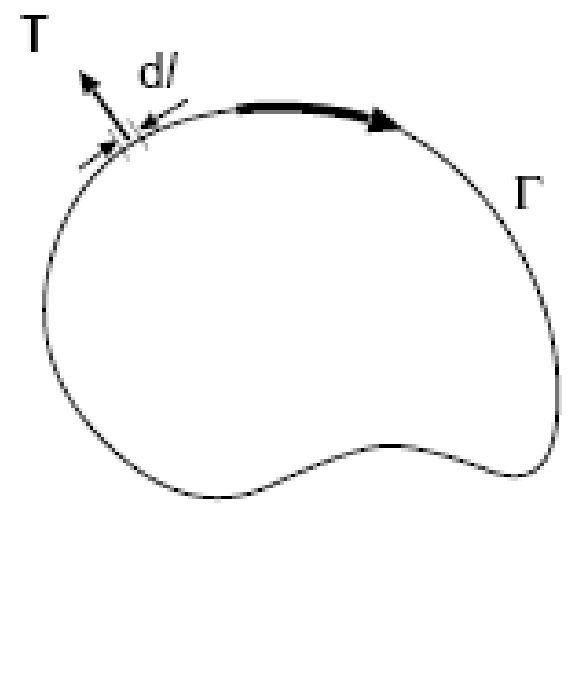

Figura 2.5: Representação de um contorno de linha em um sólido elástico não linear, usado para demonstrar a independência do caminho da integral J [11].

A aplicação de $\mathrm{J}$ a trincas se baseia no contorno esquematizado na figura 2.6: 


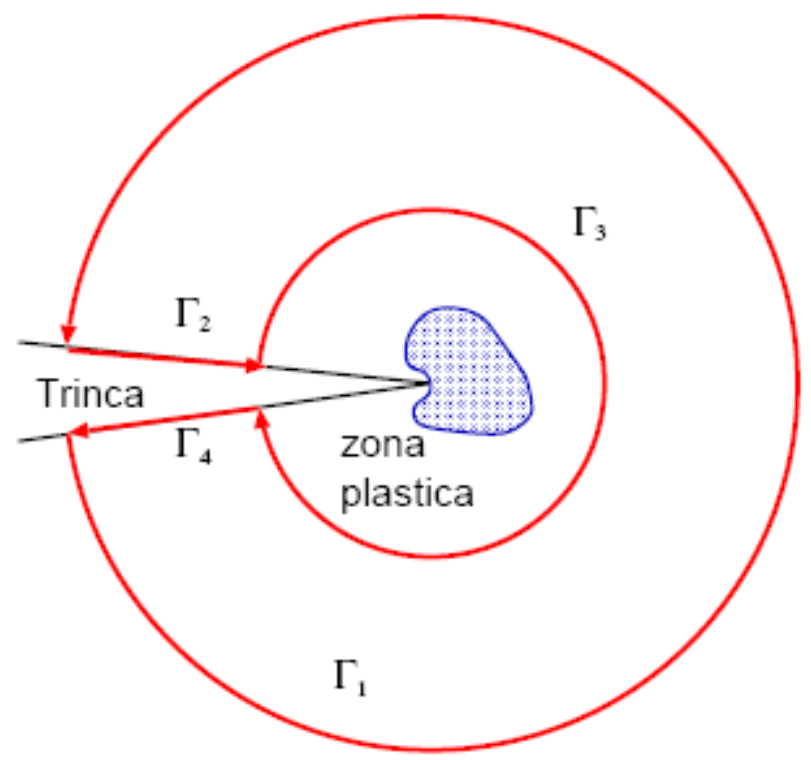

Figura 2.6: Contorno de integração utilizado na análise do uso de $\mathrm{J}$ como critério para propagação de trincas [11].

Rice e Cherepanov argumentaram que nos trechos do contorno que se situam nas faces das trincas (ou seja, $\Gamma_{2}$ e $\Gamma_{4}$ ) tanto as tensões quanto a tração devem se anular (por serem superfícies livres). Desta forma:

$$
\mathrm{J}_{\Gamma 1}+\mathrm{J}_{\ulcorner 3}=0 \rightarrow \mathrm{J}_{\Gamma 1}=\mathrm{J}_{\ulcorner\zeta 3}
$$

Como o contorno escolhido é aleatório, a relação obtida acima implica que $\mathrm{J}$ é uma constante independente do caminho, desde que este se inicie em uma face da trinca e termine na outra (o que equivale dizer, desde que ele circunde a ponta da trinca).

A integral de linha é usada única e exclusivamente para demonstrar que $\mathrm{J}$ independe do caminho de integração. No caso de trincas, é possível mostrar que $\mathrm{J}$ corresponde à diferença de energia de dois corpos sólidos contendo trincas de tamanhos a e a + da. 


$$
J \equiv \frac{d U}{d a}
$$

A equação (2.9) sugere que $J$ é a generalização da força de extensão de trinca para o caso elasto-plástico e que, portanto, os mesmos métodos experimentais podem ser utilizados na sua determinação.

Donato, Cravero e Ruggieri [5] sugeriram a medição de CTOD e integral $J$ através de um método alternativo, ETA, e chegaram à conclusão que este possibilita a determinação mais acurada dos parâmetros $\mathrm{J}$ e CTOD em relação aos métodos experimentais fundamentados na taxa de liberação de energia para materiais lineares e não lineares.Para aplicações estruturais, é necessária uma combinação adequada entre a resistência à fratura $\left(K_{\mathrm{Ic}}\right)$ e o limite de escoamento $\left(\sigma_{\mathrm{y}}\right)$ do material. No entanto, estas propriedades são inversamente proporcionais a qualquer temperatura. Para aços inoxidáveis austeníticos, a resistência à fratura diminui monotonicamente em relação ao limite de escoamento. Nos aços 304, a resistência à fratura varia em função do limite de escoamento de acordo com:

$$
\mathrm{K}_{\mathrm{Ic}}=500-0,3 \cdot \sigma_{\mathrm{y}}
$$

Onde:

$\mathrm{K}_{\mathrm{lc}}$ é a resistência à fratura em MPa.m $\mathrm{m}^{0,5}$ e $\sigma_{\mathrm{y}}$ é o limite de escoamento em MPa [17].

\subsection{Diagramas de fases Fe-Cr-Ni}

Diagramas de fase fornecem uma indicação de quais fases são termodinamicamente estáveis em uma dada composição química a determinada temperatura [18]. Os diagramas de fases possuem limitações como [19]: o equilíbrio 
é, em geral, dificilmente atingido; e os diagramas de fases não contemplam as fases metaestáveis, que podem possuir propriedades tecnológicas de interesse. Caso haja três componentes no diagrama de fases, este é denominado ternário. A figura 2.7 ilustra uma projeção tridimensional de um diagrama de fases ternário. Projeções tridimensionais podem ser úteis no entendimento da relação entre os elementos em um diagrama, porém sua leitura é difícil. Uma maneira de facilitar sua interpretação pode ser através da fixação da temperatura, conforme mostram as figuras 2.8 e 2.9 ou mantendo-se constante a concentração de um dos elementos do diagrama ternário, através de uma reta paralela a um dos lados do diagrama ternário, obtendose um diagrama denominado pseudobinário. A figura 2.10 mostra o diagrama pseudobinário $70 \% \mathrm{Fe}-\mathrm{Cr}-\mathrm{Ni}$.

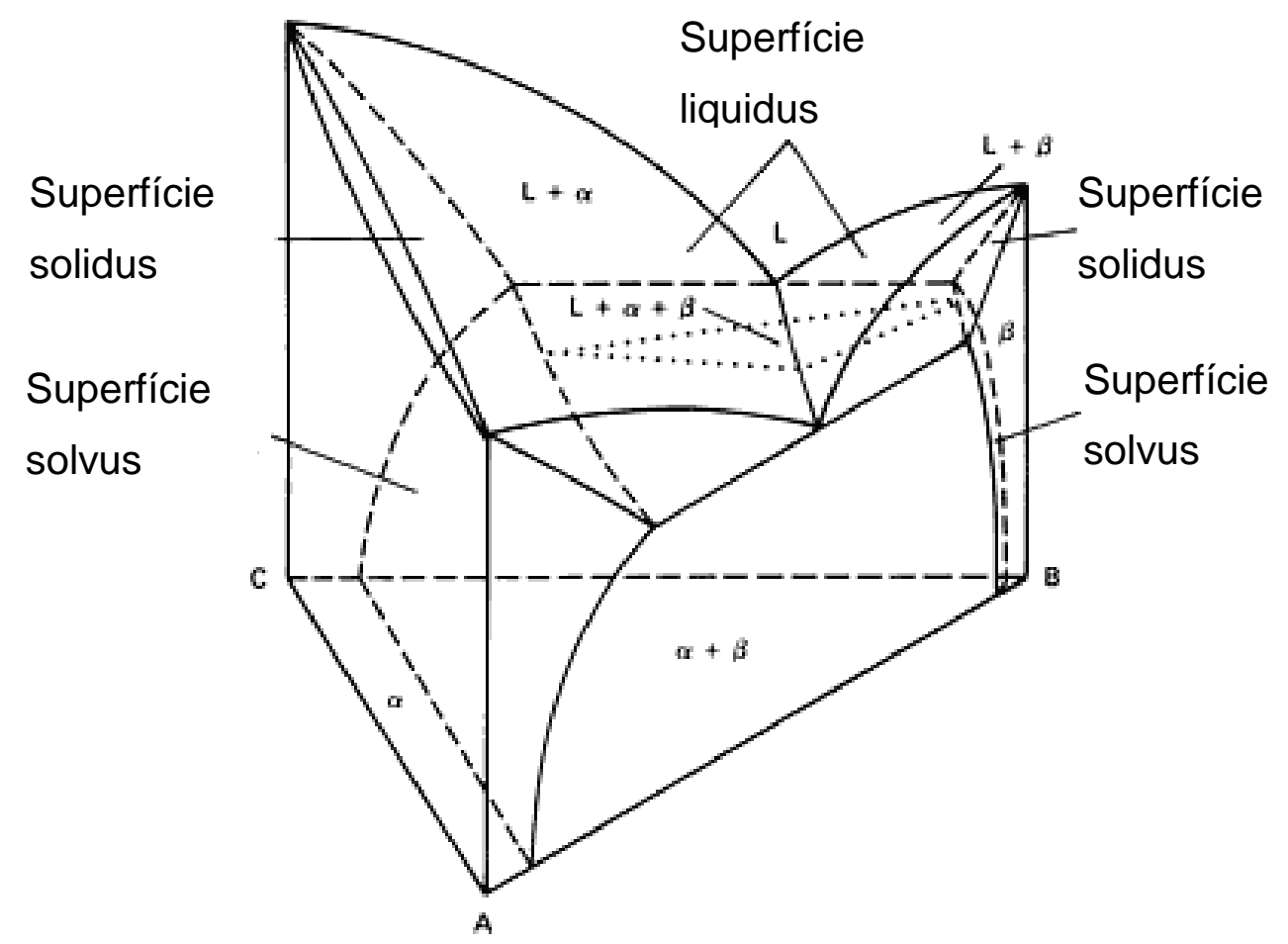

Figura 2.7: Projeção tridimensional de um diagrama de fases ternário [18]. 


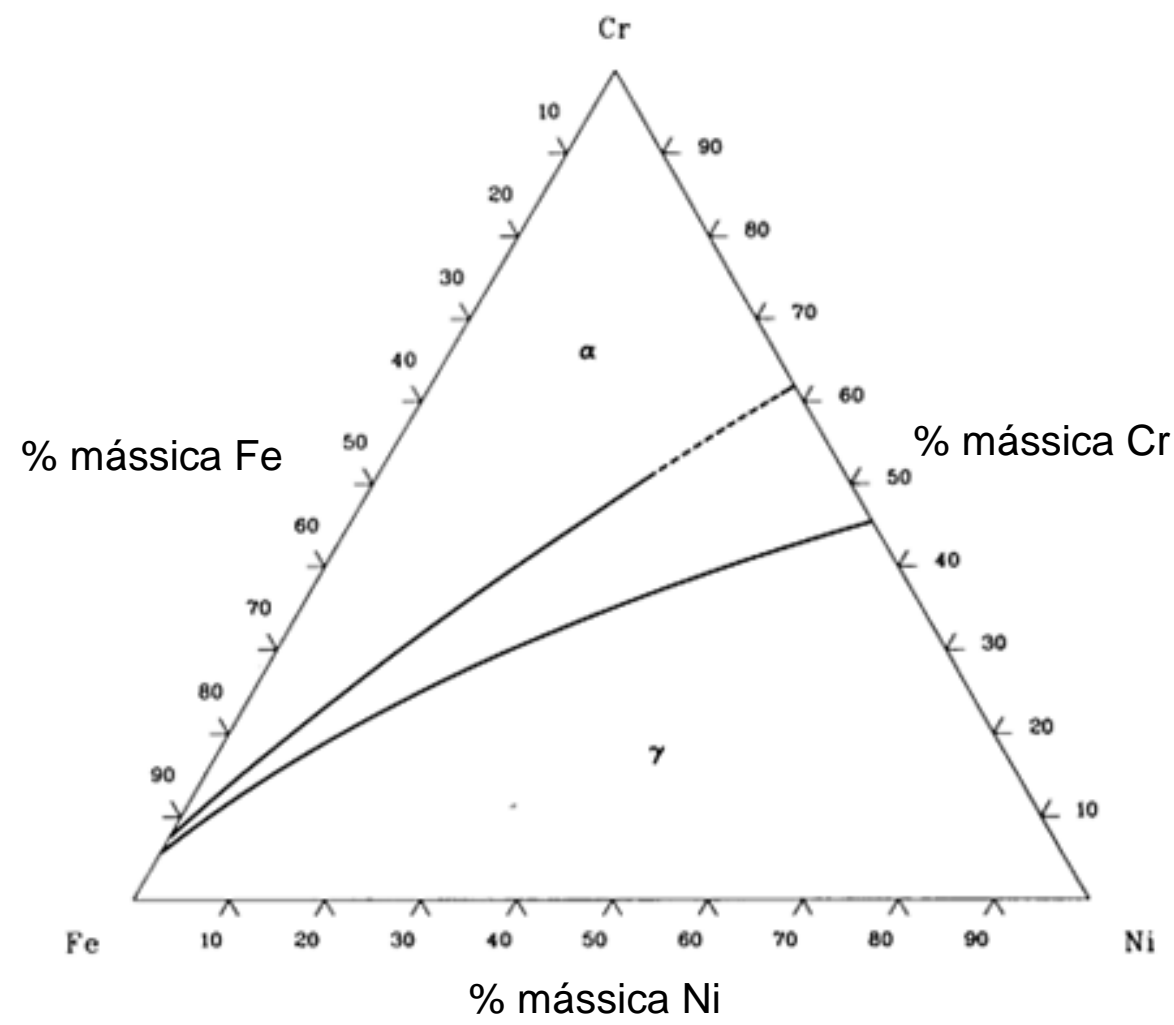

Figura 2.8: Isoterma do diagrama de fases ternário Fe-Cr-Ni a $1300^{\circ} \mathrm{C}$ [20].

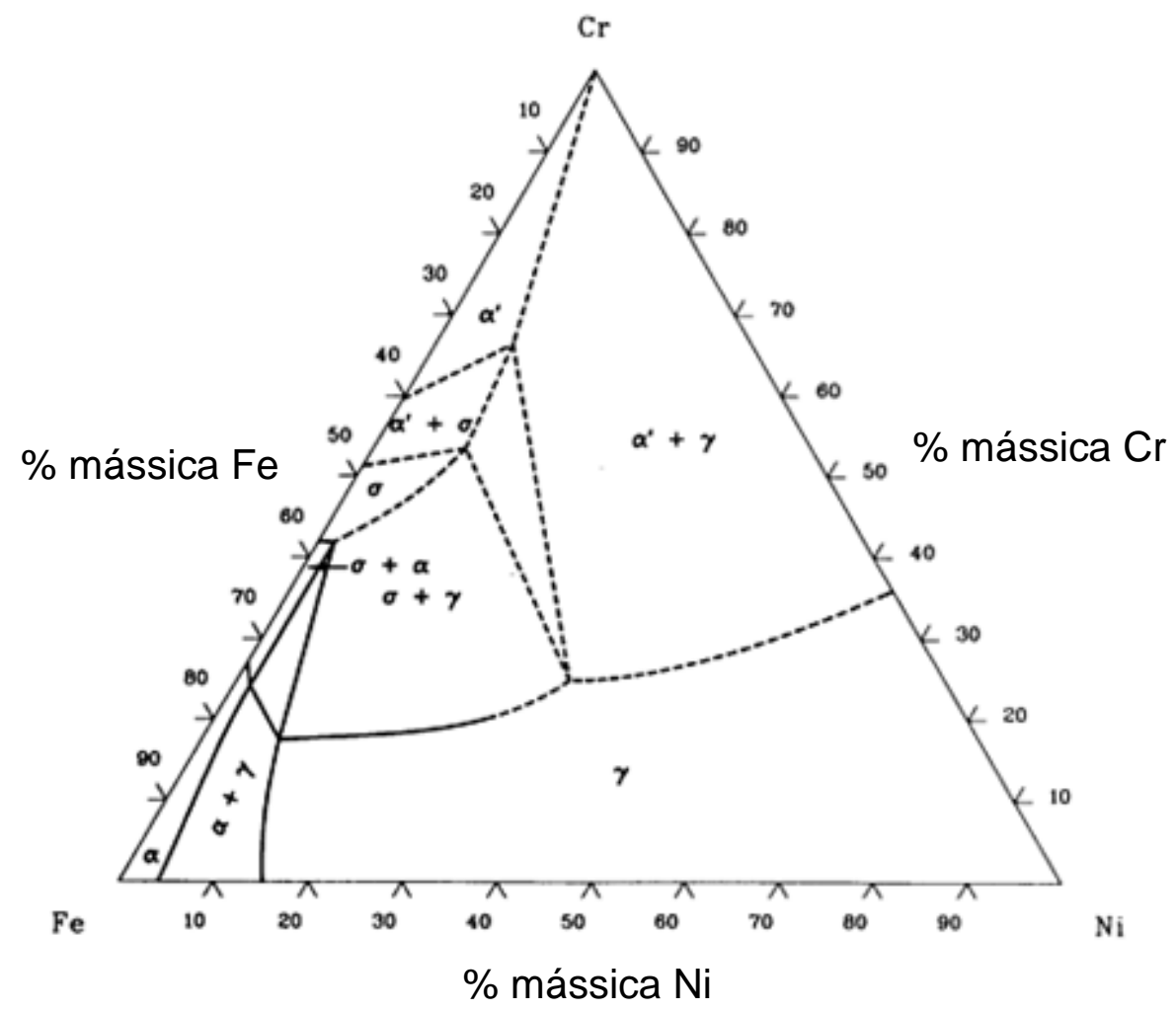

Figura 2.9: Isoterma do diagrama de fases ternário Fe-Cr-Ni a $650^{\circ} \mathrm{C}[20]$. 
De acordo com Padilha e Guedes [19], o sistema Fe-Cr-Ni constitui a base dos aços inoxidáveis. As ligas deste grupo podem apresentar microestrutura ferrítica, austenítica, martensítica ou ferrítica-austenítica, dependendo da composição química do aço.

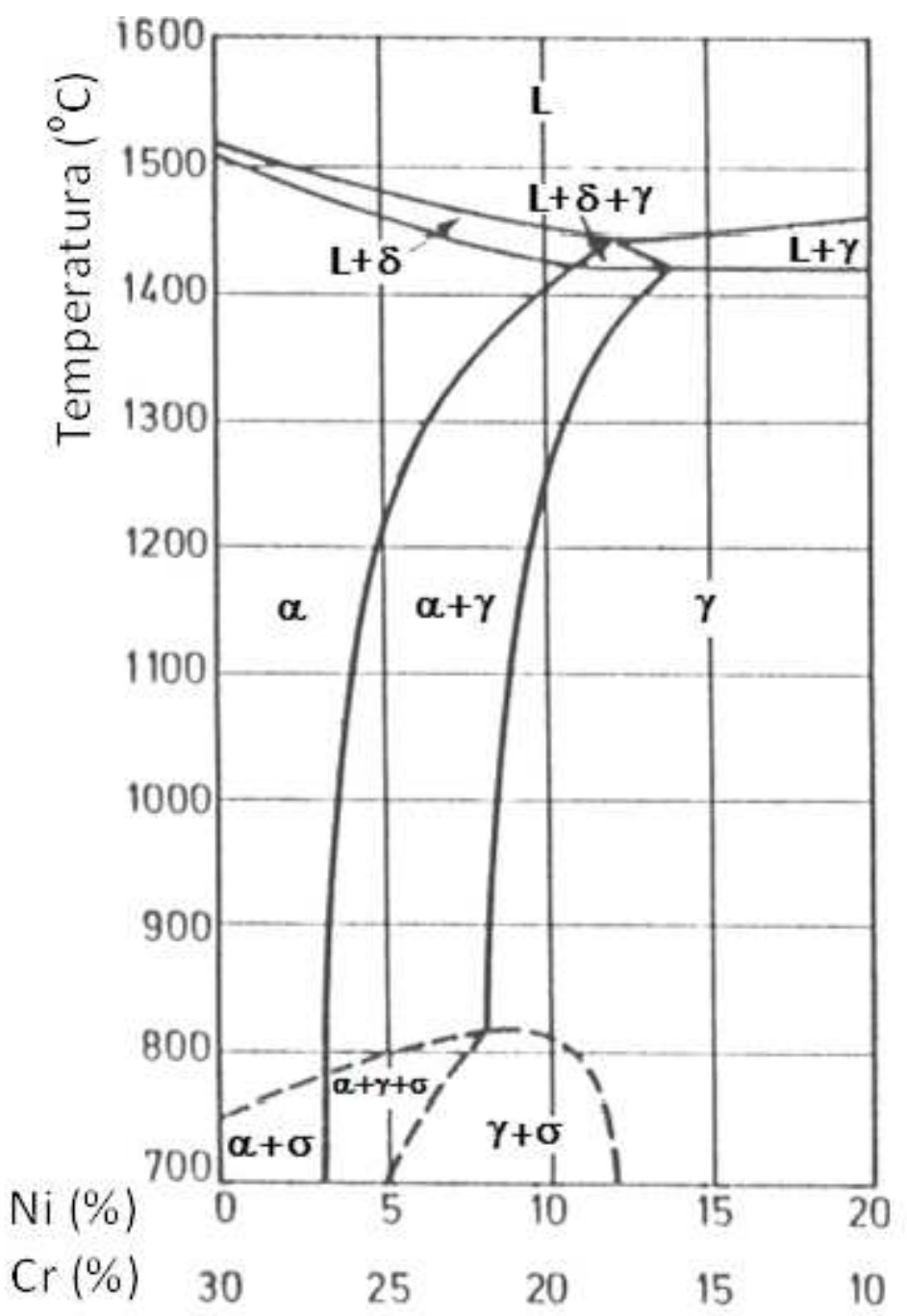

Figura 2.10: Diagrama pseudobinário 70\%Fe-Cr-Ni. [19]

\subsection{Aços inoxidáveis}


Os aços inoxidáveis são comumente divididos em cinco grupos distintos: martensíticos, ferríticos, austeníticos, duplex (ferrítico-austeníticos) e endurecidos por precipitação (envelhecidos) [21]. Cada um destes grupos será apresentado sucintamente a seguir.

\subsubsection{Aços Inoxidáveis martensíticos}

Aços inoxidáveis martensíticos consistem em ligas de cromo e carbono que possuem uma estrutura cristalina tetragonal de corpo centrado (TCC) distorcida (martensítica) e endurecida. São ferromagnéticos, endurecidos por tratamentos térmicos e, em geral, com resistência à corrosão apenas razoável [21].

O teor de cromo usualmente se encontra entre 10,5 e 18\%, sendo que o teor de carbono pode ultrapassar $1,2 \%$. Os teores de cromo e carbono são balanceados para garantir uma estrutura martensítica após o endurecimento. Alguns elementos que podem ser adicionados aos aços inoxidáveis martensíticos e seus respectivos efeitos são:

- Carbonetos são de interesse para maior resistência ao desgaste ou para manter superfícies cortantes;

- Nióbio, silício, tungstênio e vanádio podem ser adicionados para modificar o efeito da têmpera após o endurecimento;

- Pequenos teores de níquel podem ser adicionados para aumentar a resistência à corrosão e a tenacidade;

- Enxofre e selênio melhoram a usinabilidade.

\subsubsection{Aços Inoxidáveis ferríticos}

Aços inoxidáveis ferríticos são essencialmente ligas contendo cromo com estrutura cristalina cúbica de corpo centrada (CCC). São ferromagnéticos e podem 
possuir boa ductilidade e formabilidade, porém sua resistência a altas temperaturas é inferior a de aços inoxidáveis austeníticos. Sua tenacidade é relativamente limitada a baixas temperaturas [21].

O teor de cromo pode variar entre 10,5 e até 30\%. Alguns aços inoxidáveis ferríticos podem conter molibdênio, silício, alumínio, titânio e nióbio. Enxofre e selênio podem ser adicionados para melhora na usinabilidade.

\subsubsection{Aços Inoxidáveis duplex}

Aços inoxidáveis duplex possuem em sua microestrutura cristalina tanto ferrita cúbica de corpo centrado (CCC) quanto austenita cúbica de face centrada (CFC) [21]. A resistência à corrosão de aços inoxidáveis duplex é semelhante a de aços inoxidáveis austeníticos com elementos de liga similares, porém possuem maior resistência à tração e limite de elasticidade, além de maior resistência à corrosão sob tensão. Sua tenacidade é intermediária entre os aços inoxidáveis ferríticos e austeníticos.

O teor de cada fase é função da composição química e do tratamento térmico. A maioria das ligas é desenvolvida para conter o mesmo teor de cada fase quando recozidas. Seus principais elementos de liga são cromo e níquel, porém outros elementos (nitrogênio, molibdênio, cobre, silício e tungstênio) podem ser adicionados para se controlar o balanço micro estrutural e alterar a resistência à corrosão.

\subsubsection{Aços Inoxidáveis endurecidos por precipitação (envelhecidos)}

Aços inoxidáveis envelhecidos são ligas cromo-níquel contendo elementos que favorecem o endurecimento por precipitação, tais como cobre, alumínio ou titânio. Podem apresentar uma microestrutura tanto austenítica quanto ferrítica quando 
recozidos [21]. Quando apresentam microestrutura austenítica, em geral podem ser transformados em martensita através de tratamentos térmicos. Estes aços apresentam elevada dureza devido à estrutura martensítica.

\subsubsection{Aços Inoxidáveis austeníticos}

Aços inoxidáveis austeníticos possuem uma estrutura cristalina cúbica de face centrada (CFC). Esta estrutura é obtida através de elementos austenitizadores, tais como níquel, manganês e nitrogênio. Estes aços são não magnéticos quando recozidos e podem ser endurecidos apenas por deformação a frio. Apresentam excelentes propriedades criogênicas e boa resistência a altas temperaturas [21].

O teor de cromo varia entre 16 e $26 \%$, o teor de níquel é de até $35 \%$ e, de manganês, até $15 \%$. A série 300 contém altos teores de níquel, e manganês até $2 \%$.

Os aços inoxidáveis austeníticos representam o maior e mais utilizado grupo entre os aços inoxidáveis, sendo o aço AISI 304 o mais comum [23]. Apresentam baixo limite de escoamento e elevados limite de resistência e ductilidade à temperatura ambiente, além de possuir boa soldabilidade e resistência à corrosão. Podem ser utilizados tanto a temperaturas criogênicas (em que apresentam elevada tenacidade) quanto a temperaturas próximas a $600{ }^{\circ} \mathrm{C}$ (nas quais possuem boa resistência à oxidação) [24].

A série de aços inoxidáveis 300 é amplamente utilizada nas indústrias energética, petroquímica e nuclear para componentes tais como vasos de pressão, tubos de caldeiras e tubulações de vapor [25]. Nestas aplicações, os aços soldados operam a temperaturas acima da ambiente. Os aços inoxidáveis austeníticos também são largamente utilizados à temperatura ambiente ou abaixo dela, como temperaturas criogênicas. Nestes casos, suas propriedades mecânicas e resistência à corrosão usualmente são de interesse. 


\subsubsection{Microestrutura e propriedades mecânicas}

Os aços inoxidáveis austeníticos são recomendados em aplicações criogênicas, pois sua transição dúctil-frágil é desprezível a temperaturas maiores que $-269^{\circ} \mathrm{C}$ [26]. Esta transição em aços ferríticos e martensíticos ocorre alguns graus Celsius abaixo de zero, por isso na soldagem de aços inoxidáveis para aplicações criogênicas a formação de ferrita pode reduzir sua resistência, além de levar à formação de martensita durante o resfriamento. Isto ocorre porque a formação de martensita nucleia em regiões onde a microestrutura é similar a sua própria, e a ferrita apresenta estrutura cúbica de corpo centrado (sendo a martensita tetragonal de corpo centrado). Para aplicações a baixas temperaturas, o uso de aços inoxidáveis austeníticos também é recomendado, uma vez que a austenita apresenta maior ductilidade que a ferrita.

No caso do metal de solda dos aços inoxidáveis austeníticos, a matriz é, em geral, de duas fases (apresentando tanto austenita quanto ferrita) de acordo com o modo de solidificação $[22,27,28,29,30]$, que será apresentado adiante. A presença de ferrita, mesmo em pequenas quantidades (normalmente menos de $10 \%$ ), pode gerar uma fratura dúctil ou frágil dependendo da temperatura. A alta temperatura ou temperatura ambiente, a ferrita é dúctil: consequentemente, sua fração volumétrica e morfologia não controlam o mecanismo de fratura. Já a baixas temperaturas ou temperaturas criogênicas, a ferrita se torna frágil e pode levar à redução na resistência à fratura da solda. Ao contrário do metal de solda, o metal de base (austenítico) sofre uma variação pequena em sua tenacidade com a redução da temperatura [31].

De acordo com Hertzberg [4], o efeito da temperatura na energia necessária para fraturar o material está relacionado, em aços ferríticos, a uma alteração no mecanismo de fratura microscópica, que se dá por clivagem em baixas temperaturas e Ihe dá o caráter frágil. $\mathrm{Na}$ clivagem, a fratura ocorre ao longo de planos cristalográficos de diversos grãos e tem morfologia similar a um rio, pois ao mudar de direção devido a um contorno de grão de alto ângulo, ocorre mudança na orientação do plano de clivagem. 
Segundo Inoue [32], dependendo da temperatura pode ocorrer um escoamento em pequena escala (a temperatura criogênica) ou um escoamento em grande escala (temperatura baixa, ambiente ou alta) durante a propagação da trinca. Em geral, a ferrita acicular apresenta maior resistência que a ferrita vermicular em uma matriz austeníca-ferrítica durante escoamento em pequena escala. Isto ocorre porque durante a propagação da trinca na ferrita a baixas temperaturas, a ferrita vermicular é geralmente mais contínua e alinhada que a ferrita acicular, sendo que nesta o caminho médio de propagação da trinca é menor que na ferrita vermicular. A austenita (dúctil) dificulta a propagação da trinca.

Kamiya e Kumagai [33] verificaram o efeito da microestrutura nas propriedades mecânicas a baixa temperatura em aços SUS304L soldados por arco submerso. Em seu estudo, ocorreu fratura frágil na região com ferrita delta vermicular. Ibrahim [31] observou fratura dúctil na austenita caracterizada pela formação de alvéolos.

Segundo Biggs e Pratt [34], os principais requisitos para a fratura nuclear são:

- Acúmulo de discordâncias no contorno de grão;

- Uma matriz rígida em torno do contorno de grão, onde as discordâncias estão presas aos átomos de soluto de maneira a retardar o escoamento na região.

Em seus estudos, os cristais que sofreram fratura frágil falharam por clivagem, exibindo superfícies relativamente planas (001). Biggs e Pratt acreditam que a fratura por clivagem nucleia no empilhamento de discordâncias no contorno de macla. Durante a propagação da trinca por clivagem, as tensões à frente da trinca nucleiam novas maclas, as quais seguram a trinca temporariamente, mas são insuficientes para impedir sua propagação.

À temperatura não severa, aços inoxidáveis tendem a falhar exclusivamente por um mecanismo de ruptura em que micro-vazios nucleiam em inclusões e partículas de ferrita [25]. Através deste mecanismo, os micro-vazios crescem e chegam à eventual coalescência, ou seja, juntam-se a micro-vazios vizinhos. Consequentemente, a resistência à fratura média é controlada pela densidade e morfologia das partículas de segunda fase. Devido à ferrita ser dúctil às 
temperaturas elevadas e à temperatura ambiente, sua fração volumétrica e sua morfologia não controlam o mecanismo de fratura, mas sim a densidade de inclusões. No entanto, a baixas temperaturas a ferrita é frágil e pode levar à redução na resistência à fratura da solda.

Liu et al. [35] estudou a fractografia da fratura frágil a baixa temperaturas do aço inoxidável austenítico 18Cr-18Mn-N (o aço inoxidável AISI 304, também austenítico, é $18 \mathrm{Cr}$-8Ni). Foram verificados o modo de fratura e o comportamento de propagação da trinca a 4, 77 e $293 \mathrm{~K}$ através de ensaio. As curvas tensão $x$ deformação para 4, 77 e $293 \mathrm{~K}$ estão representadas na figura 2.11 , já a figura 2.12 mostra a energia absorvida nos ensaios Charpy em função da temperatura.

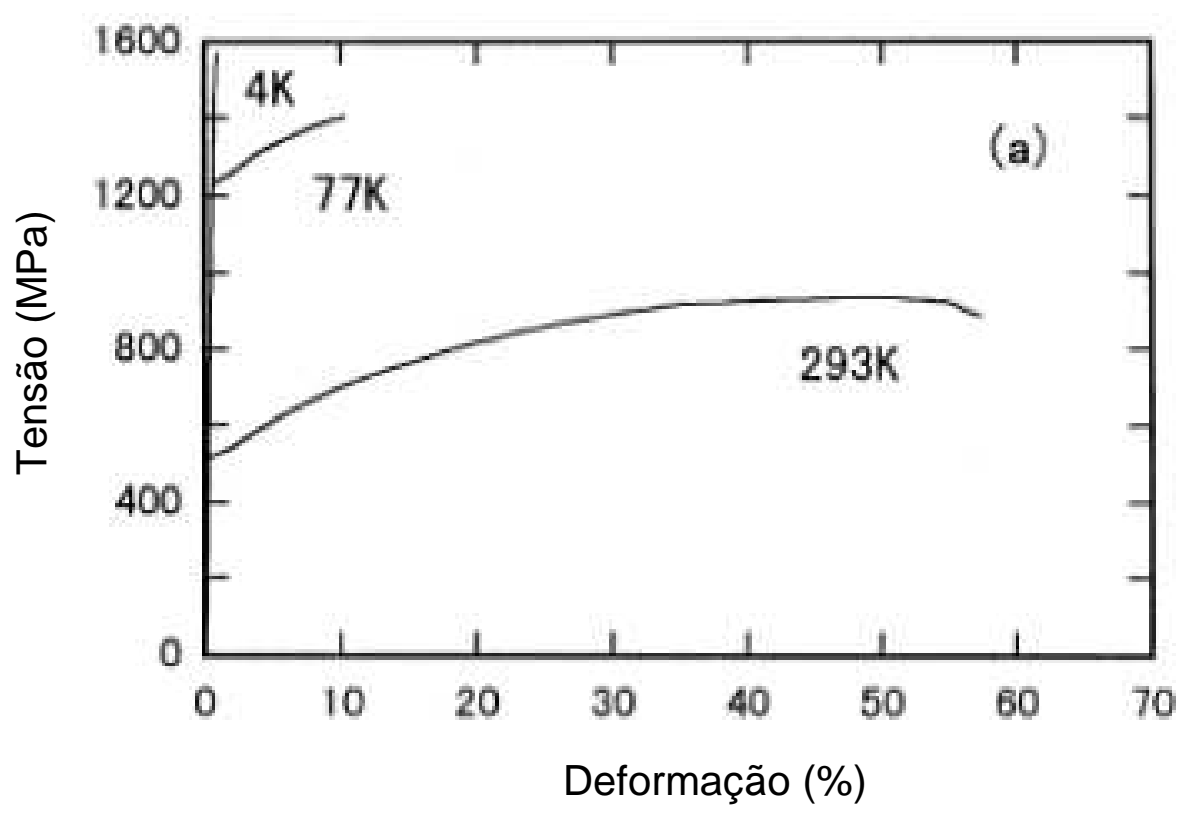

Figura 2.11: Curva tensão x deformação do aço $18 \mathrm{Cr}-18 \mathrm{Mn}-0,7 \mathrm{~N}$ para 4,77 e $293 \mathrm{~K}$ [35]. Com a redução da temperatura, observa-se um aumento do limite de escoamento e redução da deformação plástica antes da ruptura do material (ductilidade). 


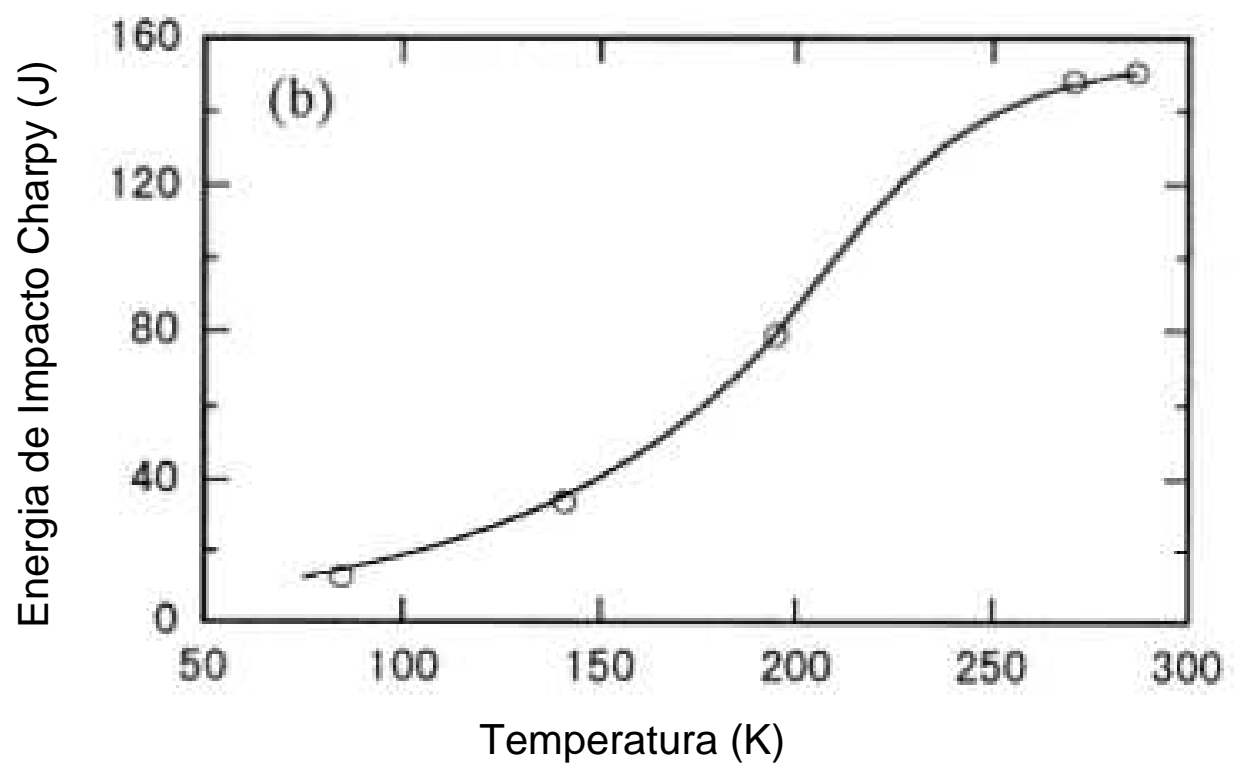

Figura 2.12: Energia absorvida no ensaio Charpy em função da temperatura para o aço $18 \mathrm{Cr}$ $18 \mathrm{Mn}-0,7 \mathrm{~N}$ [35]. O aumento da temperatura aumenta a energia absorvida pelo corpo de prova antes de se fraturar (aumento de sua tenacidade).

$\mathrm{Na}$ curva tensão $\mathrm{x}$ deformação observa-se que o limite de escoamento aumenta significativamente a $77 \mathrm{~K}$ em relação a $293 \mathrm{~K}$. A 4 K, o limite de escoamento atingiu cerca de $1600 \mathrm{MPa}$, rompendo em um regime elástico linear. Assim, a redução na temperatura reduz a deformação plástica sofrida pelo material antes do rompimento (ductilidade). Já o ensaio Charpy demonstrou que a energia absorvida vai diminuindo com a redução da temperatura, ou seja: quanto menor a temperatura, menor a tenacidade.

Neste estudo, os autores verificaram que as trincas se iniciam nos contornos de grão e se propagam pela coalescência das trincas com a trinca principal. A principal causa da fratura frágil a baixas temperaturas nestes metais é a fratura intergranular.

Em ensaios CTOD para verificar o efeito da temperatura no ensaio Charpy e nos valores de CTOD no aço inoxidável austenítico AISI 304 para tubulações de transporte de gás liquefeito de petróleo (GLP), Baek et al. [36] chegou aos resultados indicados na figura 2.13 para os ensaios de CTOD como termos elásticos e plásticos $\left(\delta=\delta_{\text {elástico }}+\delta_{\text {plástico }}\right)$. Os componentes plásticos reduzem significativamente com a redução da temperatura, enquanto os componentes elásticos são relativamente invariáveis com a temperatura, indo de acordo com o 
trabalho de Liu et al. [35] A redução na resistência à tração está associada à diminuição do componente plástico com o decréscimo da temperatura. A tabela 2.2 resume o efeito da temperatura nas propriedades mecânicas dos aços inoxidáveis austeníticos:

Tabela 2.2: Efeitos do aumento da temperatura em aços inoxidáveis austeníticos.

\begin{tabular}{|c|c|}
\hline $\begin{array}{c}\text { Propriedade ou capacidade do } \\
\text { material }\end{array}$ & $\begin{array}{c}\text { Efeito a partir do aumento da } \\
\text { temperatura }\end{array}$ \\
\hline Módulo de elasticidade & Pouco se altera \\
\hline Ductilidade & Aumenta \\
\hline Tenacidade & Aumenta \\
\hline Limite de escoamento & Diminui \\
\hline
\end{tabular}

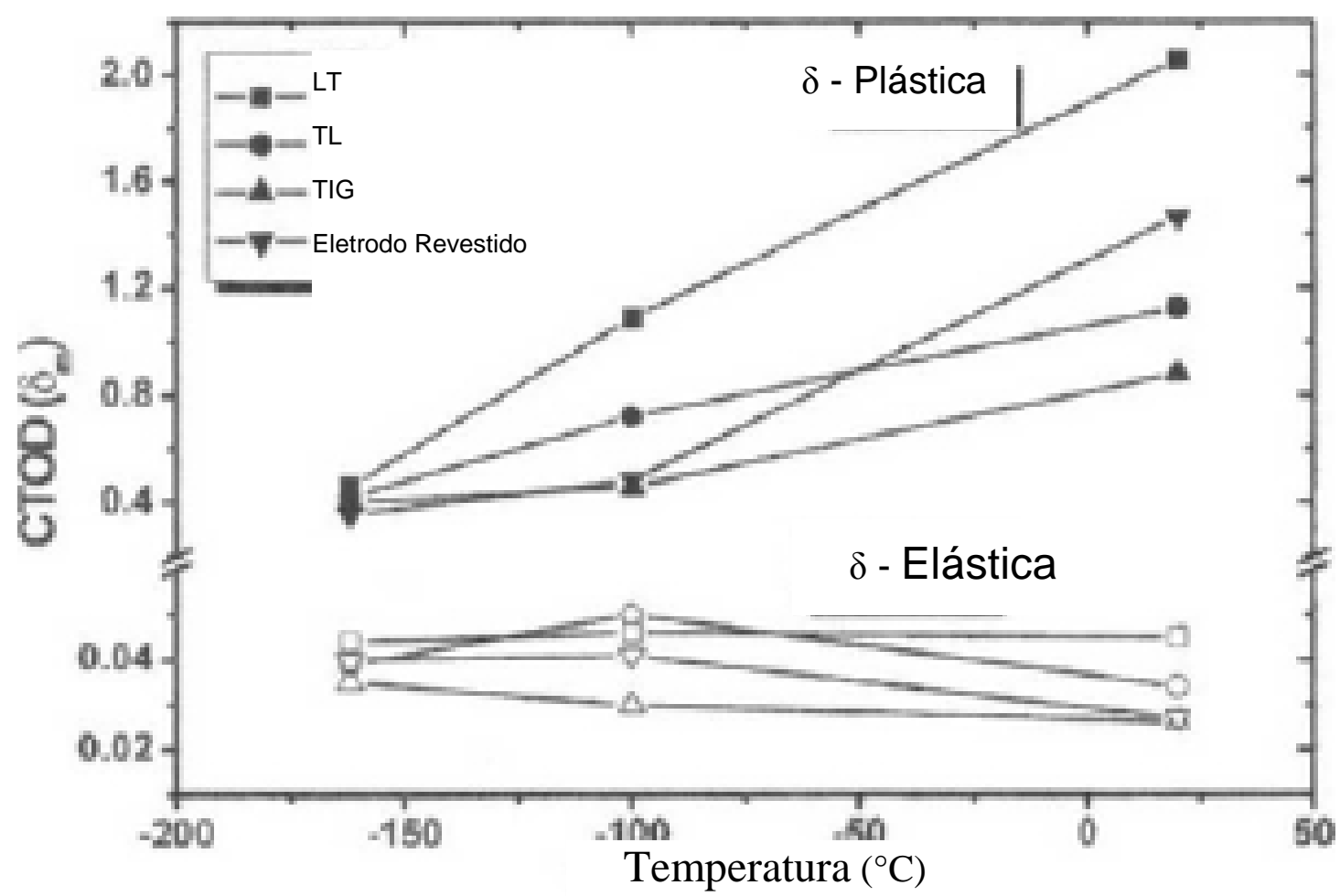

Figura 2.13: Variação dos valores de CTOD em função da temperatura no metal de base (LT e TL) e de solda (soldagens TIG e por eletrodo revestido) [29]. A componente elástica da deformação permanece praticamente inalterada com a variação da temperatura, ao contrário da componente plástica que aumenta com a temperatura. 
A figura 2.14 se refere a micrografias de corpos de prova de CTOD dos metais de base e de solda no estudo de Baek et al [36]. Os alvéolos formados na direção transversal são muito mais profundos e maiores que os alvéolos no eixo longitudinal em relação à direção de laminação. Isto se deve ao desenvolvimento da frente da trinca ser impedido pelo contorno de grão quando a trinca propaga transversalmente à direção de laminação durante os testes de CTOD. Também há diferença entre o tamanho do alvéolo no metal de base dependendo da temperatura, de 10-15 $\mu \mathrm{m}$ a temperatura ambiente a $3-4 \mu \mathrm{m}$ a $-162^{\circ} \mathrm{C}$.

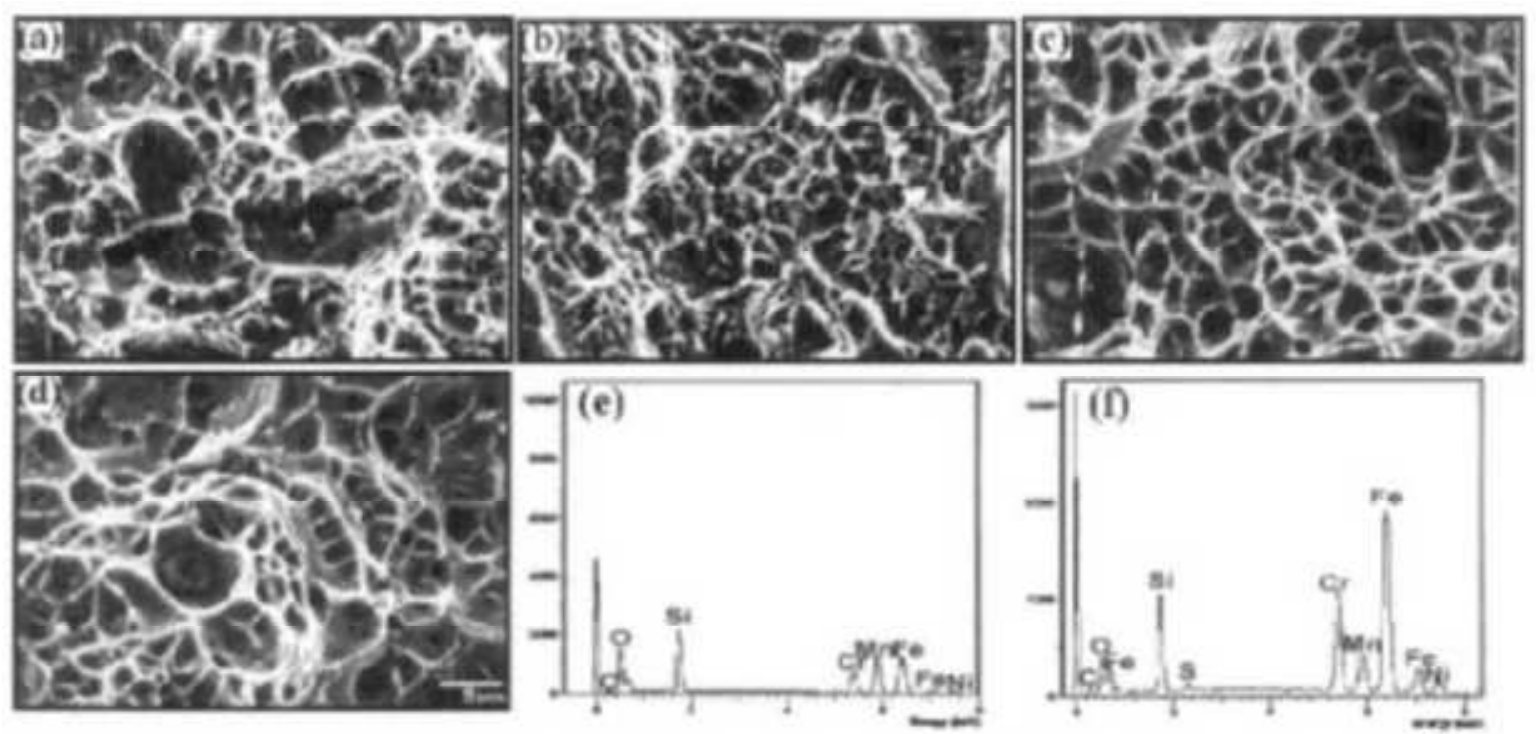

Figura 2.14: Microscopia eletrônica de varredura e EDS dos metais de base e de solda em corpos de prova de CTOD a $-162^{\circ} \mathrm{C}$ : metal de base $\mathrm{LT}$ (a), metal de base TL (b), eletrodo revestido (c), TIG (d), EDS de (c) (e) e EDS de (d) (f) [36].

De acordo com Lancaster [37], na soldagem de aços inoxidáveis austeníticos $18 \mathrm{Cr}-(10-12) \mathrm{Ni}$ a solubilidade de oxigênio e nitrogênio é maior que no ferro, principalmente devido ao teor de cromo. Na soldagem por arco submerso, o teor de oxigênio decresce com o aumento do índice de basicidade do fluxo [38, 39], conforme a figura 2.15. Baixos teores de oxigênio são necessários para boa ductilidade do material a baixas temperaturas, porém o teor de oxigênio possui pouco efeito nas propriedades e microestrutura do metal de solda. 
O índice de basicidade é utilizado principalmente para se determinar o aumento no teor de oxigênio na soldagem por arco submerso, uma vez que ele fornece uma medida aproximada da capacidade de oxidação do fluxo [40]. Há diversas expressões sugeridas para o cálculo do índice de basicidade, sendo a equação a seguir proposta por Eagar [39]:

$$
\begin{gathered}
I B=\frac{\sum(\% \text { óxidos básicos })}{\sum(\% \text { óxidos não-básicos })}= \\
\frac{\mathrm{CaO}+\mathrm{MgO}+\mathrm{BaO}+\mathrm{SrO}+\mathrm{Na}_{2} \mathrm{O}+\mathrm{K}_{2} \mathrm{O}+\mathrm{Li}_{2} \mathrm{O}+1 / 2(\mathrm{MnO}+\mathrm{FeO})}{\mathrm{SiO}_{2}+1 / 2\left(\mathrm{Al}_{2} \mathrm{O}_{3}+\mathrm{TiO}_{2}+\mathrm{ZrO}_{2}\right)}
\end{gathered}
$$

As concentrações dos óxidos são dadas em porcentagem mássica. A partir da figura 2.15, que apresenta a relação típica entre o teor de oxigênio no metal de solda e o índice de basicidade, observa-se que o teor de oxigênio de soldagens realizadas com fluxos ácidos (baixo índice de basicidade) é fortemente influenciado pelo I. B. No caso de fluxos básicos, observa-se que não ocorre esta relação, dada pela linha horizontal do gráfico. 


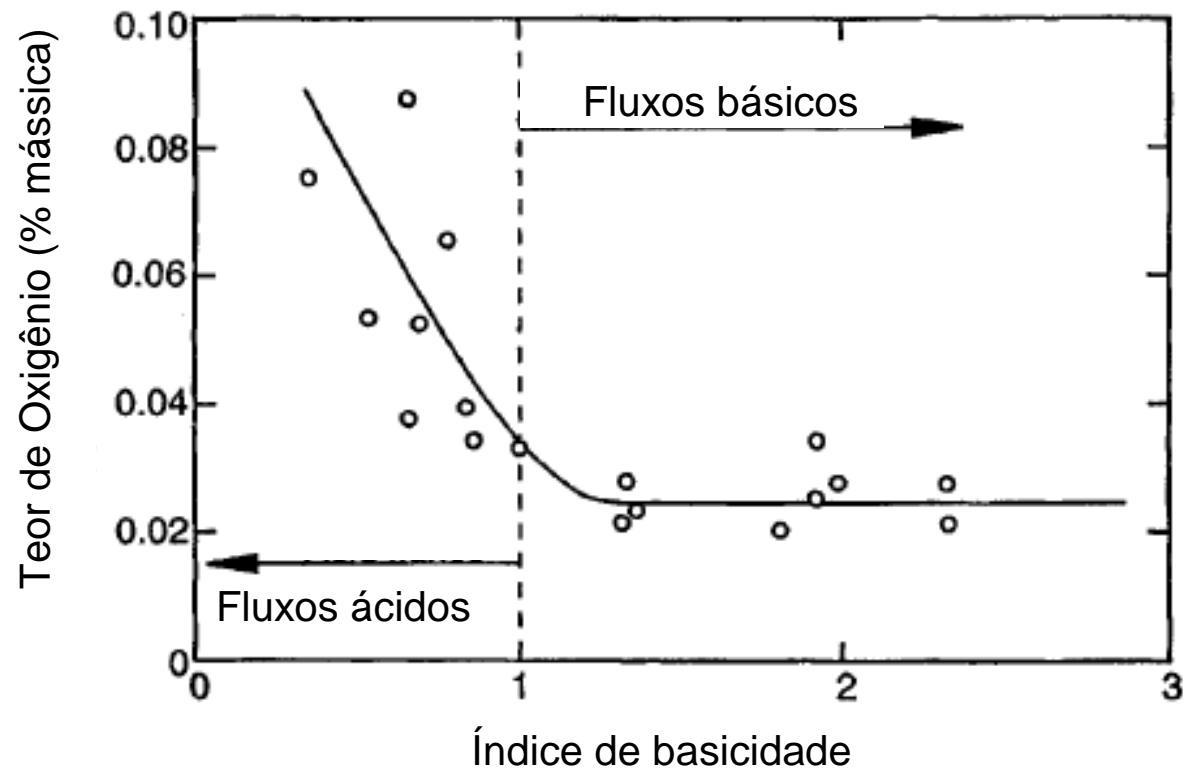

Figura 2.15: Teor de oxigênio no metal de solda em função do índice de basicidade na soldagem por arco submerso de aço carbono [39].

Fatores que afetam a resistência de aços inoxidáveis austeníticos a baixas temperaturas são os teores de carbono, cromo, níquel, oxigênio e ferrita [37]. Carbono aumenta a resistência da matriz, porém aumenta o teor de partículas de segunda fase. Um aumento no teor de carbono afeta a facilidade para ocorrer a coalescência de alvéolos, reduzindo a energia necessária para fraturar o material em cerca de $2,4 \mathrm{~J}$ para cada $0,01 \% \mathrm{C}$ a $-196{ }^{\circ} \mathrm{C}$. Preferencialmente, o teor de carbono para aplicações sub-zero é mantido abaixo de 0,04\%.

Cromo é o maior elemento formador de carboneto, por isso reduz a resistência à fratura em aproximadamente $1,2 \mathrm{~J}$ para cada $1 \% \mathrm{Cr}$ a $-196{ }^{\circ} \mathrm{C}$ [37]. Níquel favorece a formação de austenita, aumentando a resistência à fratura, mas Molibdênio, por ser um formador de ferrita, também leva a redução da mesma. Para um metal de solda $308 \mathrm{~L}$ em arco submerso, os resultados de teste de impacto Charpy-V a $20^{\circ} \mathrm{C}$ e $-196{ }^{\circ} \mathrm{C}$ são dados, respectivamente, por:

$$
\begin{gathered}
\mathrm{KV}_{+20}=1491,1-386,2 \mathrm{O}_{2}-3,3 \mathrm{FN} \\
\mathrm{KV}_{-196}=95,1-310,7 \mathrm{O}_{2}-1,5 \mathrm{FN}
\end{gathered}
$$


Onde $\mathrm{O}_{2}$ é o teor de oxigênio em massa e FN é o número de ferrita. Segundo Hägg [41], um baixo teor de oxigênio leva a uma maior resistência a impacto, o que vai de acordo com os experimentos de Lancaster [37], representados na figura 2.16 que apresenta a energia de impacto no ensaio Charpy- $\mathrm{V}$ a $-196{ }^{\circ} \mathrm{C}$ em função do teor de oxigênio para soldagens a arco submerso.

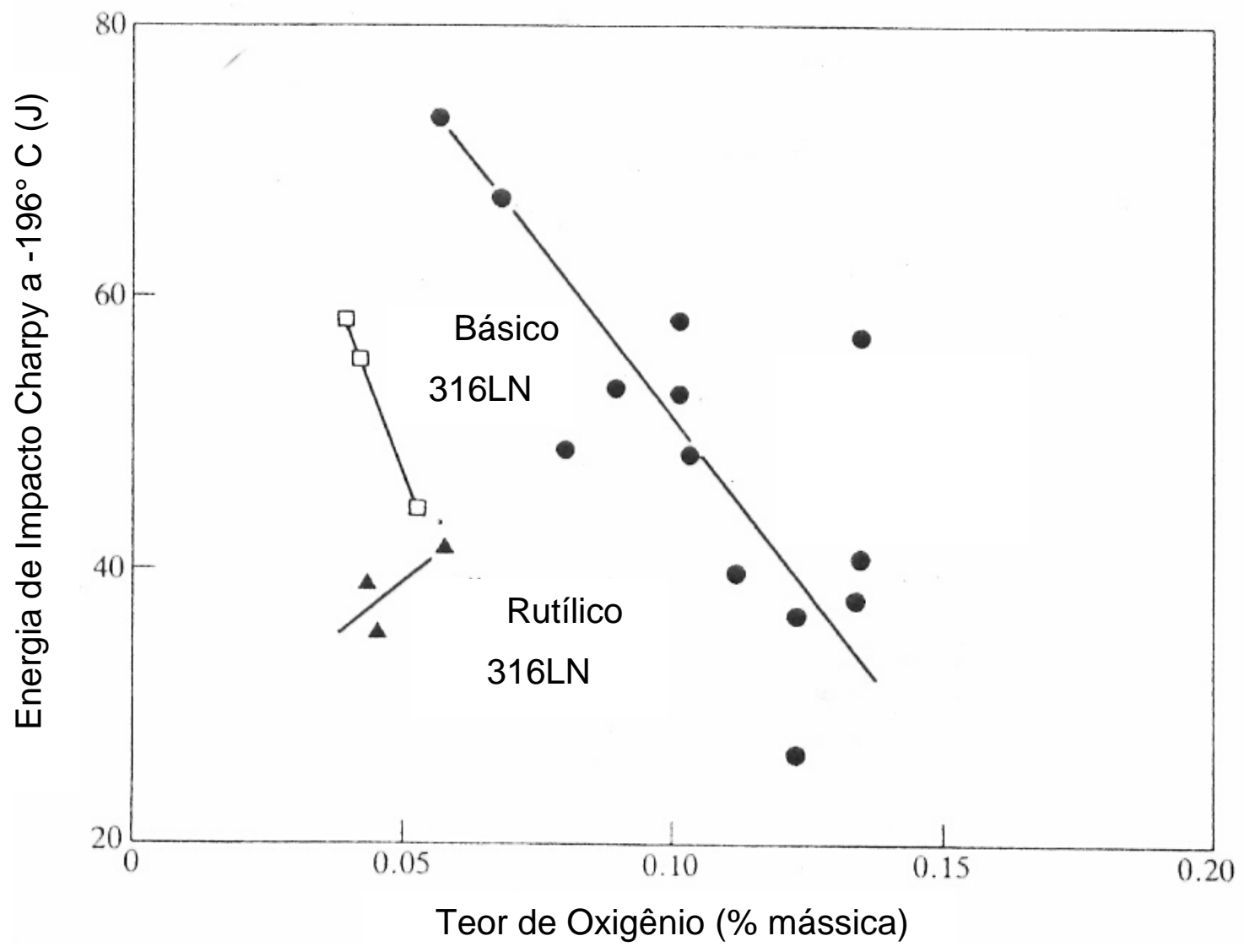

Figura 2.16: Energia de impacto Charpy- $\mathrm{V}$ a $-196{ }^{\circ} \mathrm{C}$ para metal de solda $308 \mathrm{~L}$ a arco submerso e soldagens em $316 \mathrm{LN}$ realizadas com eletrodos com revestimento básico e de rutilo. [37]

O manganês atua de duas maneiras distintas em aços inoxidáveis austeníticos, de acordo com sua concentração: Quando em baixas concentrações, atua como um austenitizador, já em concentrações entre $5 \%$ e $8 \%$, age como ferritizador.

O nitrogênio, de maneira similar ao oxigênio, favorece a formação de austenita [37, 42]. Este efeito varia com a temperatura. Isto pode estar associado aos diferentes equilíbrios das fases em diferentes temperaturas, ou a fatores cinéticos 
como a difusão destes elementos intersticiais: Uma maior facilidade de difusão de nitrogênio e oxigênio favorece a transformação de ferrita em austenita durante o resfriamento.

O estudo de Enjo, Kikuchi e Moroi [43] indicou que o aumento no teor de nitrogênio em um aço inoxidável AISI 304 é benéfico em sua capacidade de absorver impactos até aproximadamente 1600 1700 ppm, conforme a figura 2.17. Provavelmente até esta concentração, o nitrogênio é dissolvido pela austenita. A partir desta faixa, deve ocorrer sua precipitação.

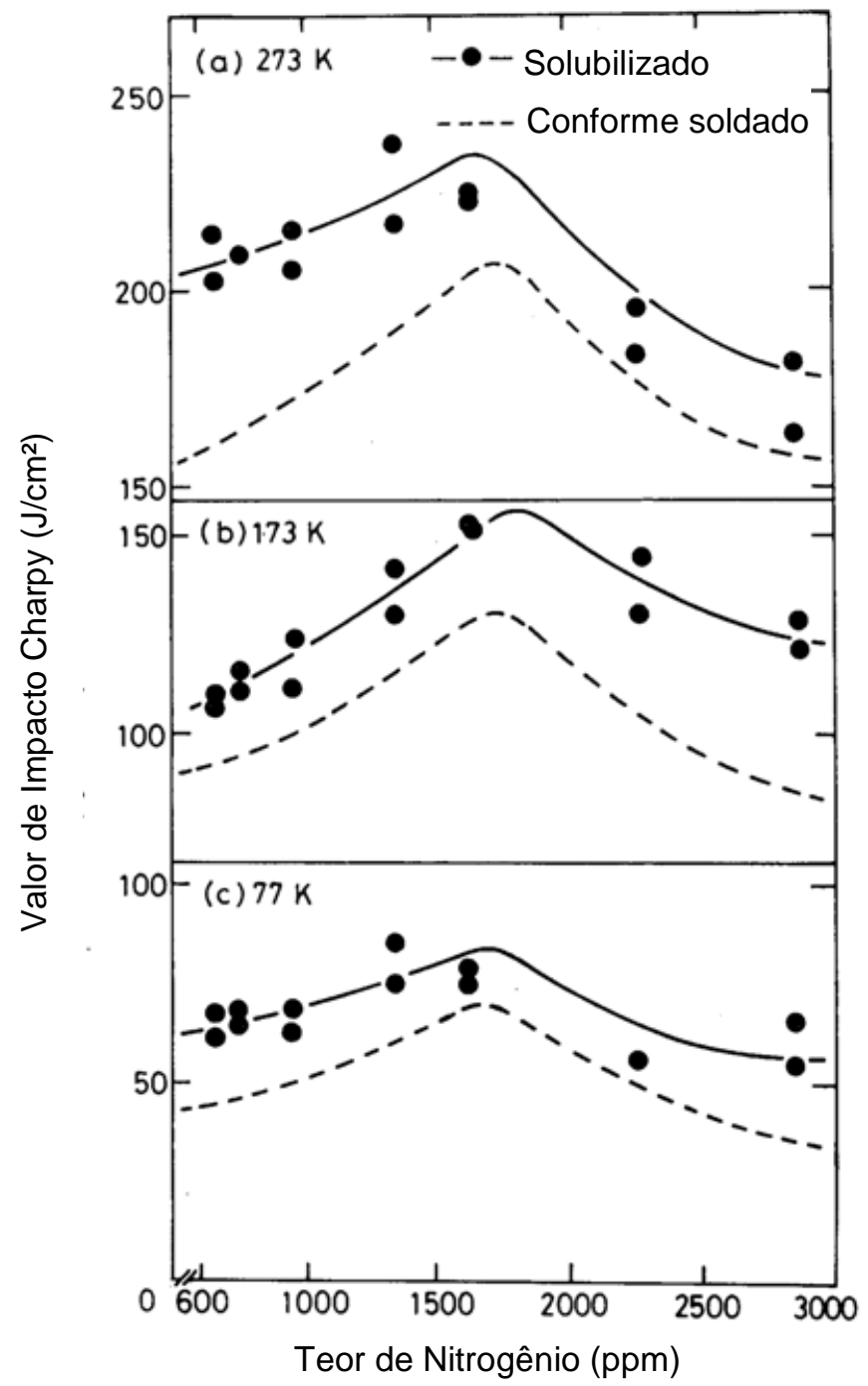

Figura 2.17: Efeito do teor de Nitrogênio no ensaio Charpy para material soldado por eletrodo revestido com e sem tratamento térmico de solubilização. [43] 
A tabela 2.3 a seguir apresenta resumidamente os efeitos de diferentes elementos de liga nas propriedades mecânicas de aços inoxidáveis austeníticos a baixas temperaturas:

Tabela 2.3: Efeitos de diferentes elementos de liga nas propriedades mecânicas de aços inoxidáveis austeníticos a baixas temperaturas.

\begin{tabular}{|c|c|c|}
\hline $\begin{array}{l}\text { Elemento } \\
\text { de liga }\end{array}$ & Efeitos positivos & Efeitos negativos \\
\hline $\mathrm{O}$ & $\begin{array}{l}\text { Age como austenitizador (sua } \\
\text { difusão facilita a transformação } \\
\text { de ferrita em austenita). }\end{array}$ & Reduz ductilidade. \\
\hline C & $\begin{array}{c}\text { Aumenta resistência à fratura da } \\
\text { matriz. }\end{array}$ & $\begin{array}{c}\text { Aumenta teor de partículas de } \\
\text { segunda fase. }\end{array}$ \\
\hline $\mathrm{Cr}$ & - & $\begin{array}{c}\text { Reduz resistência à fratura } \\
\text { (favorece formação de carboneto). }\end{array}$ \\
\hline $\mathrm{Ni}$ & $\begin{array}{c}\text { Aumenta resistência à fratura } \\
\text { (favorece formação de austenita). }\end{array}$ & - \\
\hline Mo & - & $\begin{array}{c}\text { Reduz resistência à fratura } \\
\text { (favorece formação de ferrita). }\end{array}$ \\
\hline $\mathrm{Mn}$ & $\begin{array}{l}\text { Age como austenitizador (em } \\
\text { baixas concentrações). }\end{array}$ & $\begin{array}{l}\text { Age também como ferritizador (em } \\
\text { concentrações entre } 5 \% \text { e } 8 \% \text { ). }\end{array}$ \\
\hline $\mathrm{N}$ & $\begin{array}{l}\text { Age como austenitizador (sua } \\
\text { difusão facilita a transformação } \\
\text { de ferrita em austenita). }\end{array}$ & - \\
\hline
\end{tabular}

\subsubsection{Soldagem de aços inoxidáveis austeníticos}


Os processos mais utilizados para a soldagem de aços inoxidáveis são [23]:

- SMAW (Shielded Metal Arc Welding - eletrodo revestido);

- GTAW (Gas Tungsten Arc Welding - TIG);

- GMAW (Gas Metal Arc Welding - MIG/MAG).

A soldagem por eletrodo revestido é utilizada para serviços em geral (particularmente no campo e em diferentes posições), por TIG na soldagem de peças de menor espessura, e por MIG/MAG para juntas mais espessas (apresentando maior produtividade) [23].

Segundo Modenesi [23], a soldagem de aços inoxidáveis necessita de limpeza a fim de minimizar contaminações as quais podem reduzir sua resistência à corrosão. Também se devem ter cuidados com a forma do cordão, pois irregularidades na superfície podem acumular sujeira e iniciar corrosão. Algumas diferenças nas propriedades físicas entre aços comuns e inoxidáveis também devem ser levadas em conta durante a soldagem:

- Menor temperatura de fusão;

- Menor condutividade térmica;

- Maior coeficiente de expansão térmica;

- Maior resistência elétrica.

Aços inoxidáveis austeníticos são relativamente simples de se soldar, exceto aços com adição de enxofre (para melhorar usinabilidade) [23]. Os aços austeníticos apresentam coeficiente de expansão térmica cerca de $45 \%$ maior, maior resistência elétrica e menor condutividade térmica que aços doces. Caso o teor de carbono seja maior que $0,06 \%$, pode ocorrer a precipitação de carbonetos nos contornos de grão da zona afetada pelo calor durante o ciclo térmico da soldagem, prejudicando assim sua resistência à corrosão. Para minimizar este efeito, recomenda-se que a soldagem seja realizada com maior velocidade de deslocamento.

Devido sua menor temperatura de fusão e condutividade térmica, os aços inoxidáveis austeníticos geralmente utilizam uma corrente de soldagem menor que a 
utilizada para aços doces [23]. Porém, devido ao metal de solda de aços inoxidáveis austeníticos apresentarem maior viscosidade, a corrente de soldagem não pode ser muito baixa pois leva à falta de penetração. Seu maior coeficiente de expansão térmica os torna susceptíveis a distorções durante a soldagem, sendo necessárias técnicas para minimizá-las. Por exemplo, utilizam-se dispositivos de fixação e ponteamento cuidadoso na soldagem de chapas finas. Para aplicações criogênicas, em que é necessária uma estrutura completamente austenítica na região da solda, deve-se utilizar eletrodos com baixos teores de enxofre e fósforo e elevada relação $\mathrm{Mn} / \mathrm{S}$, além de procurar minimizar as tensões na solda.

As dificuldades encontradas na soldagem de aços inoxidáveis são oriundas de reações de micro constituintes dos aços à temperatura de soldagem, ou de interações entre os aços e ligas dissimilares [23]. A fim de eliminar a diluição, é necessário utilizar uma baixa energia de soldagem durante o primeiro passo de soldagem. Isto pode ser realizado com um eletrodo de diâmetro pequeno a uma corrente mais baixa e uma tensão mais alta. Também podem ser utilizados metais de adição que fornecem maior quantidade de elementos de liga, a fim de compensar possíveis diluições.

Em aços inoxidáveis austeníticos, como o AISI 304, a resistência à corrosão da zona afetada pelo calor de uma solda pode ser seriamente reduzida pela precipitação de partículas de carbeto de cromo ao longo dos contornos de grãos, que resulta em sua sensitização. A depleção em cromo na região adjacente aos contornos de grãos reduz a resistência à corrosão da matriz devido ao cromo precipitado na forma de carbeto [44].

De acordo com Chi et al. [25], um dos requisitos das soldas para a maioria dos aços inoxidáveis austeníticos é que haja ferrita suficiente em sua microestrutura para prevenir qualquer tendência a trincas durante a solidificação. Desta forma, áreas susceptíveis a trincas contendo enxofre e fósforo, conhecidos por estarem associados a problemas de trincas, podem dissolver em ferrita ao invés de precipitar na austenita. Além disso, a ausência de ferrita pode causar trincas por solidificação longitudinal no metal de adição. No entanto, altas concentrações de ferrita em aços inoxidáveis austeníticos podem levar a uma redução em sua trabalhabilidade a 
quente, e assim, em sua ductilidade. A fim de se balancear as vantagens e desvantagens da presença de ferrita delta, normalmente se especifica que a fração volumétrica de ferrita delta na microestrutura varie entre 5 a 10\%. A tabela 2.4 apresenta os efeitos de interesse e os impactos negativos da ferrita na soldagem de aços inoxidáveis austeníticos para utilização a baixas temperaturas:

Tabela 2.4: Vantagens e desvantagens da presença de ferrita durante a soldagem de aços inoxidáveis austeníticos para utilização a baixas temperaturas.

\begin{tabular}{|c|c|}
\hline Vantagem & Desvantagens \\
\hline Prevenção de trincas durante a & Redução na ductilidade a quente \\
solidificação & Redução na tenacidade a baixas \\
\cline { 2 - 2 } & temperaturas \\
\hline
\end{tabular}

Estudos anteriores mostraram que se aumentando o número de passes na soldagem por arco submerso em aço inoxidável 316L levou à deterioração da ductilidade e resistência ao impacto no metal da solda atribuída às alterações morfológicas causadas pelo reaquecimento e resfriamento de passes subseqüentes [25].

As soldas nos aços inoxidáveis austeníticos também tendem a falhar por um mecanismo de fratura frágil decorrente da formação e crescimento de vazios que eventualmente formam a superfície da fratura. A resistência das soldas deve, portanto, ser aumentada caso outras fases como ferrita, carbetos de cromo e inclusões sejam reduzidas ou eliminadas [4].

A fim de se prever a microestrutura da solda e possíveis problemas, podem ser utilizados diagramas empíricos como o Diagrama de Schaeffler (figura 2.18) a partir da composição química do metal em questão, expressa em função dos teores equivalentes de cromo $\left(\mathrm{Cr}_{\mathrm{eq}}\right)$ e de níquel $\left(\mathrm{Ni}_{\text {eq }}\right)$. 


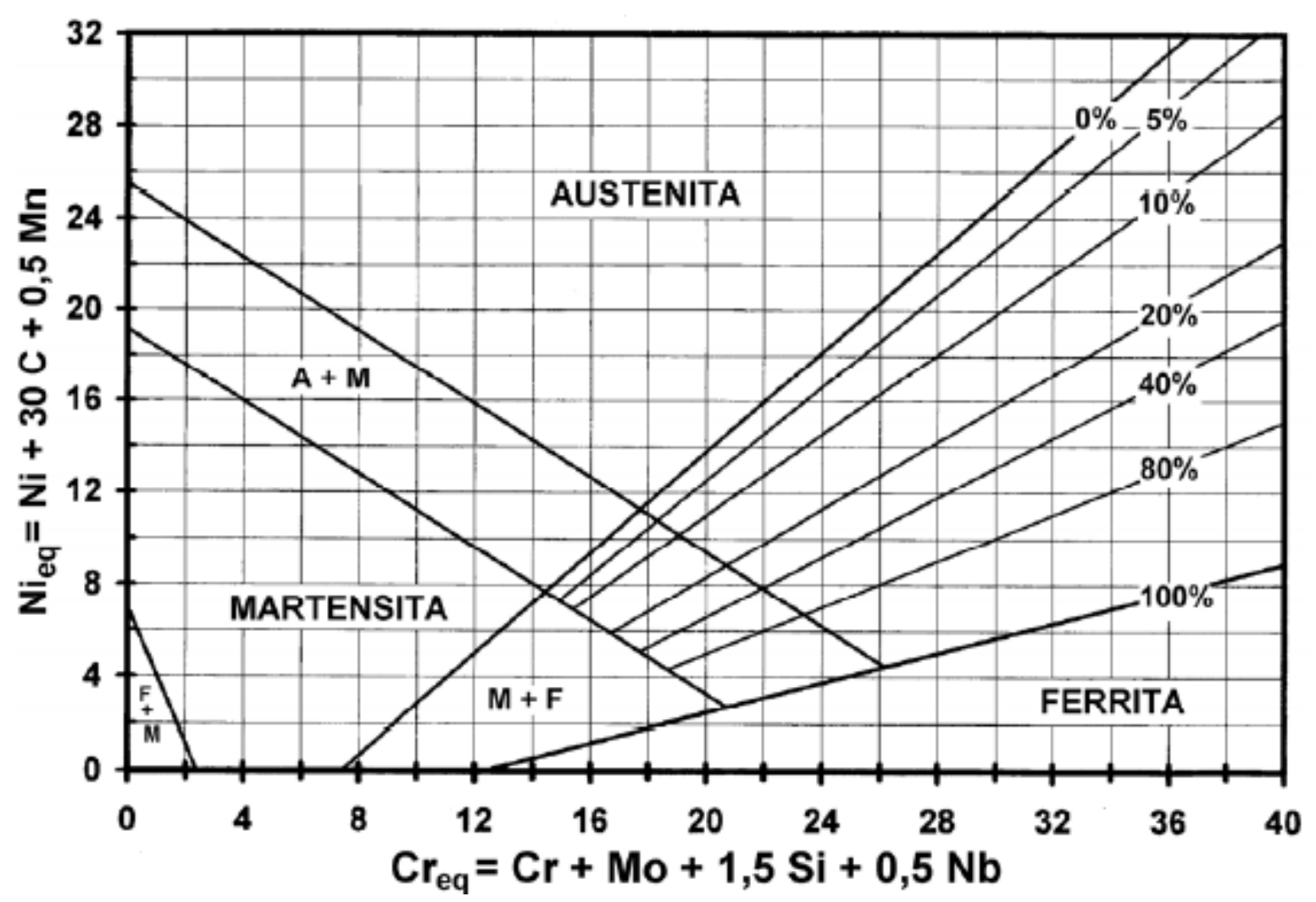

Figura 2.18: Diagrama de Schaeffler [45], através do qual se pode prever a microestrutura da solda.

O diagrama de Schaeffler adaptado para soldagem na figura 2.19 está dividido em regiões as quais representam problemas na soldagem de aços inoxidáveis:

1. Estrutura totalmente austenítica na solidificação, com elevada sensibilidade à formação de trincas durante a solidificação ou perda de ductilidade acima de $1250^{\circ} \mathrm{C}$;

2. Altos teores de liga, que acarretam formação de fases intermetálicas após aquecimento entre $450^{\circ} \mathrm{C}$ e $900^{\circ} \mathrm{C}$, levando à fragilização;

3. Estrutura ferrítica, a qual apresenta grande crescimento de grão na zona afetada pelo calor e zona fundida, levando à fragilização;

4. Formação de martensita na zona afetada pelo calor e zona fundida devido a elevada temperabilidade, levando à fragilização e fissuração pelo hidrogênio e formação de martensita. 


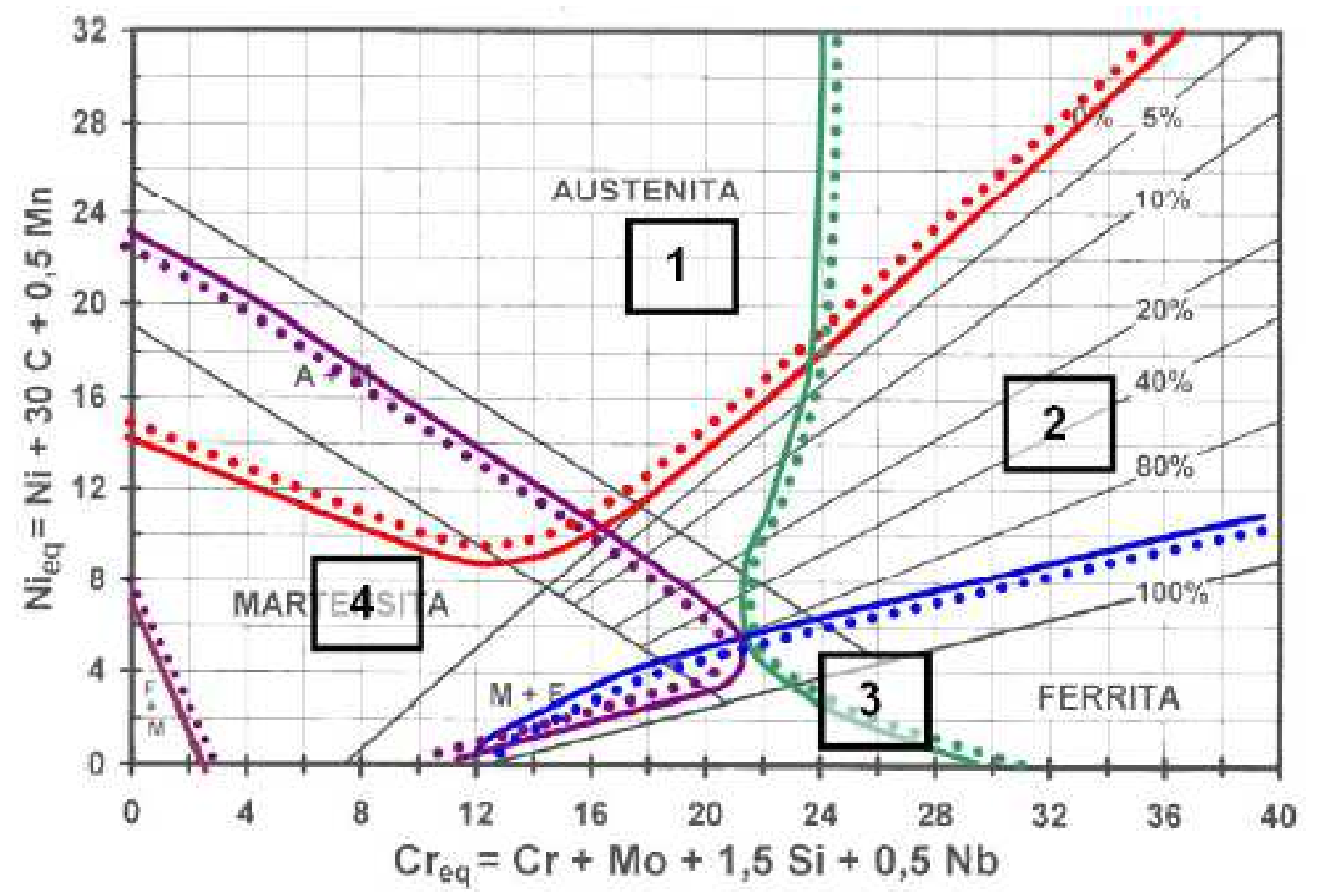

Figura 2.19: Diagrama de Schaeffler dividido em diferentes regiões problemáticas durante a soldagem de aços inoxidáveis: formação de trincas de solidificação ou por perda de ductilidade acima de $1250^{\circ} \mathrm{C}$ (1), fragilização por formação de fases intermetálicas após aquecimento entre cerca de $450^{\circ} \mathrm{C}$ e $900^{\circ} \mathrm{C}$ (2), fragilização por crescimento de grão (3), fragilização e fissuração por formação de martensita (4). [23]

Observa-se, na região central do diagrama, uma área a qual não é atingida por nenhum dos quatro problemas citados anteriormente. Desta forma, procura-se utilizar consumíveis que levem a esta região do diagrama após sua diluição com o metal de base.

\subsubsection{Reações químicas durante a soldagem}

De acordo com Grong [40], pode-se analisar a transferência de massa durante a soldagem considerando-se um modelo de reação de duas fases: 
1. Estágio de alta temperatura: as reações atingem um estado de pseudoequilíbrio local;

2. Estágio de resfriamento: as concentrações atingidas no primeiro estágio se alteram pela rejeição de elementos dissolvidos no líquido.

Conforme indicado na figura 2.20, o estágio de alta temperatura compreende tanto as interações gás-metal quanto as interações escória-metal que ocorrem na ponta do eletrodo, no plasma do arco ou na parte mais aquecida na poça de fusão, e é caracterizada pela absorção extensiva de elementos no metal líquido. Durante o estágio de resfriamento que ocorre após a passagem do arco, a supersaturação rapidamente aumenta, devido à redução na solubilidade dos elementos com a redução das temperaturas. Com isto, o sistema rejeita os elementos dissolvidos no líquido por uma reação gás-metal (desorção) ou por precipitação de novas fases. No último caso, a extensão de transferência de massa é determinada pela taxa de separação dos produtos de reação na poça de fusão. Deve-se notar que a ligação entre os dois estágios não é bem definida, ou seja, a separação de fases pode ocorrer simultaneamente com a absorção na região mais aquecida da poça de fusão. 


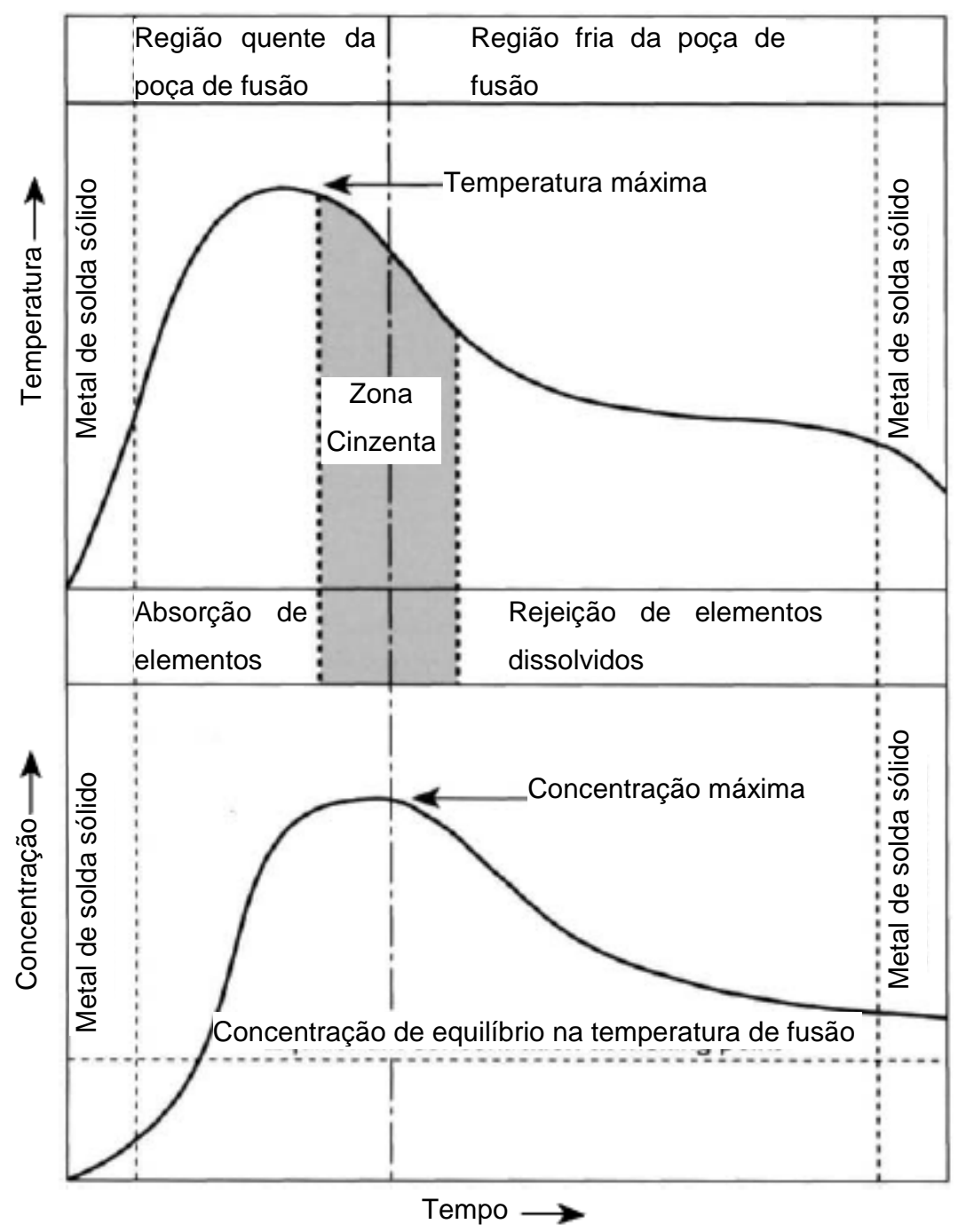

Figura 2.20: Modelo de reação de duas fases na poça de fusão. [40]

De acordo com Indacochea et al. [46], atingir o equilíbrio das reações durante o processo de soldagem é improvável devido aos seguintes fatores:

- Grandes gradientes de temperatura;

- Grandes gradientes de densidade;

- Presença de diferentes fases (escória, metal e plasma);

- Alta corrente elétrica;

- Grande transferência de energia pelo arco. 
Durante o resfriamento da poça de fusão, a concentração de oxigênio se altera através da reação com desoxidantes presentes no metal de solda. No entanto, a quantidade de oxigênio encontrada analiticamente é muito maior que a prevista termodinamicamente [47]. Isto se deve a uma separação de fases incompleta, que ocorre porque a escória precipitada possui uma densidade menor que o metal de solda fundido. No entanto, a escória não atinge o topo da região fundida devido ao pequeno intervalo de tempo para crescimento e flotação das partículas, de forma que deve ser considerada a cinética das reações.

O teor de oxigênio em um metal de solda pode ser reduzido através de:

- Aumento do tempo de retenção da poça de fusão;

- Aumento da proporção manganês/silício.

O aumento do tempo de retenção da poça de fusão está relacionado ao aumento de tempo disponível para o crescimento e flotação das partículas de óxidos. Esta teoria leva em conta que a flotação possui papel importante na remoção de produtos de desoxidação da poça de fusão, sendo que a velocidade média de ascensão $v$ das partículas é aproximada pela lei de Stokes:

$$
\mathrm{v}=\frac{\mathrm{gd}_{\mathrm{p}}^{2} \Delta \rho}{18 \eta}
$$

Onde g é a constante gravitacional, $d_{p}$ é o diâmetro da partícula, $\Delta \rho$ é a diferença entre a densidade do aço fundido e das inclusões, e $\eta$ é a viscosidade do aço.

A desoxidação por $\mathrm{Si}-\mathrm{Mn}$ geralmente leva à produção de $\mathrm{SiO}_{2}$ e $\mathrm{MnO}$ fundidos, com pequena formação de $\mathrm{FeO}$. Assim, pode-se considerar a reação global entre $\mathrm{Si}$, Mn e O:

$$
\underline{\mathrm{Si}}+2(\mathrm{MnO}) \leftrightarrow 2 \underline{\mathrm{Mn}}+\left(\mathrm{SiO}_{2}\right)
$$

Quando o metal de solda apresenta uma alta proporção $\mathrm{Mn} / \mathrm{Si}$, a precipitação de manganês leva ao aumento da atividade de $\mathrm{SiO}_{2}$ no produto de reação, permitindo melhor desoxidação. No entanto, o teor de oxigênio em equilíbrio também depende da quantidade total de elementos desoxidantes presentes no aço, de maneira que uma alta proporção $\mathrm{Mn} / \mathrm{Si}$, por si só, não garanta maior desoxidação. A precipitação 
de manganês deve, em princípio, promover uma melhor separação de fase devido ao rápido aumento das partículas de óxido por coalescência.

A composição química na poça de fusão pode mudar devido a reações termoquímicas e eletroquímicas na gota da ponta do arame (durante a transferência da mesma) e na poça de fusão em contato com o arco elétrico ou com a escória fundida [46, 48, 49, 50]. Segundo Blander e Olson [48], as reações entre diferentes fases controladas pela interface devem levar em conta aspectos cinéticos e termodinâmicos do processo. As densidades de corrente na soldagem por arco submerso são mais altas na interface da escória com o arame que na interface com a poça de fusão, de forma que a probabilidade da haver uma interface escória-metal é maior na poça de fusão que no arame [51]. Para um arame anódico (eletrodo negativo), a reação anódica:

$$
\mathrm{nO}^{2-}+\mathrm{M} \rightarrow \mathrm{MO}_{\mathrm{n}}+2 \mathrm{ne}
$$

Onde $M$ é um metal na interface arame-escória e $n$ é a valência de $M$ no óxido, leva a um $\mathrm{P}_{\mathrm{O} 2}$ relativamente alto no arame, produzindo assim óxidos na interface. Caso o metal $\mathrm{M}$ seja $\mathrm{Fe}$, a reação com metais menos nobres como $\mathrm{Mn}$ (ou $\mathrm{Cr}$ ou $\mathrm{Si}$ ), é:

$$
\mathrm{FeO}+\mathrm{Mn} \leftrightarrow \mathrm{MnO}+\mathrm{Fe}
$$

A qual reduz as concentrações de $\mathrm{Mn}$ (ou $\mathrm{Cr}$ ou Si) na interface metal-óxido. O metal menos nobre difunde para a interface e reage com $\mathrm{FeO}$ para formação do óxido. Desta forma, o arame fundido preferencialmente perde os metais menos nobres para a fase do óxido da interface. Após a formação de uma gotícula formada a partir do arame se separar do mesmo, a reação eletroquímica cessa, mas reações conforme (2.16) continuam a ocorrer. Os óxidos produzidos difundem então tanto para o metal quanto para o fluxo. A velocidade de dissolução depende de fatores cinéticos e também do potencial químico do óxido na interface, na escória e na fase metálica. Assim, uma escória pobre em óxido de ferro dissolve a maior parte do produto $\mathrm{FeO}$ e reduz o aumento da concentração de oxigênio no metal de solda. Por outro lado, apenas FeO difunde significativamente no metal devido aos altos 
coeficientes e baixa solubilidade de $\mathrm{MnO}, \mathrm{Cr}_{2} \mathrm{O}_{3}$ e $\mathrm{SiO}_{2}$ no metal. As reações catódicas (em eletrodos positivos) levam à eletrodeposição dos metais:

$$
\begin{aligned}
& \mathrm{M}^{2+}+2 \mathrm{e} \rightarrow \mathrm{M} \\
& \mathrm{Si}^{4+}+4 \mathrm{e} \rightarrow \mathrm{Si}
\end{aligned}
$$

Onde $\mathrm{M}^{2+}$ pode ser $\mathrm{Fe}^{2+}, \mathrm{Mn}^{2+}$ ou outros íons metálicos no fluxo, Conforme representado na figura 2.21 :

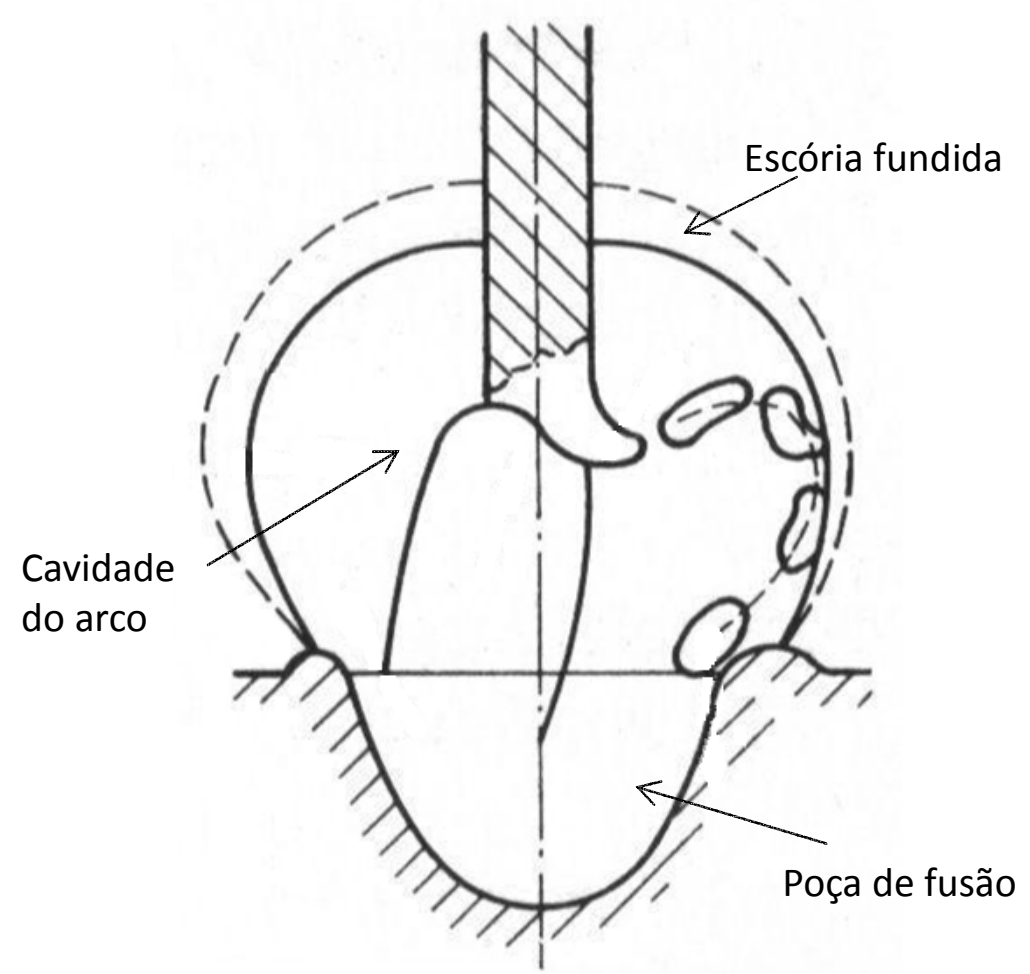

Figura 2.21: Eletrodeposição de metais em reações catódicas (eletrodo positivo). Adaptado de [49].

Mesmo quando inicialmente não há a presença de $\mathrm{FeO}$ ou $\mathrm{MnO}$, a reação (2.17) levará à formação do mesmo na interface. No contato inicial entre uma gotícula do arame fundido ou da poça de fusão com a escória, o equilíbrio da reação será atingido em uma espessura infinitesimal da interface. Caso não haja convecção em nenhuma das fases, as composições na interface permanecerão constantes 
enquanto o comprimento de difusão for relativamente pequeno em relação às dimensões das fases.

Uma possível reação de carbono com $\mathrm{SiO}_{2}$, dada a seguir, pode causar aumento da concentração de Si no metal fundido:

$$
2 \mathrm{C}+\mathrm{SiO}_{2} \leftrightarrow 2 \mathrm{CO}+\mathrm{Si}
$$

Para que (2.20) ocorra a uma velocidade significativa, o produto CO deve estar na forma gasosa, ou seja, uma bolha deve nuclear antes que a fase metálica entre em contato com o plasma do arco.

Como o teor final de oxigênio no metal de solda é controlado pela perda de óxidos precipitados antes da solidificação, a fase de separação é favorecida pelas condições turbulentas existentes na região quente da poça de fusão logo abaixo do arco [47]. Neste caso, a turbulência aumenta a probabilidade de colisão e coalescência das inclusões, além de favorecer sua subida à superfície.

A seqüência de reações durante a desoxidação pode ser esquematizada conforme a figura 2.22. Nela assume-se que o equilíbrio entre os reagentes e a escória precipitada é mantido até a temperatura de solidificação, de forma que a poça de fusão possa ser dividida em duas regiões principais:

- Zona "quente" da poça de fusão, caracterizada pela oxidação e desoxidação simultâneas do metal, onde a separação de escória precipitada ocorre continuamente devido à elevada turbulência;

- Zona "fria" da poça de fusão, onde permanece a maioria da escória precipitada como partículas finas dispersas, devido à baixa turbulência. 


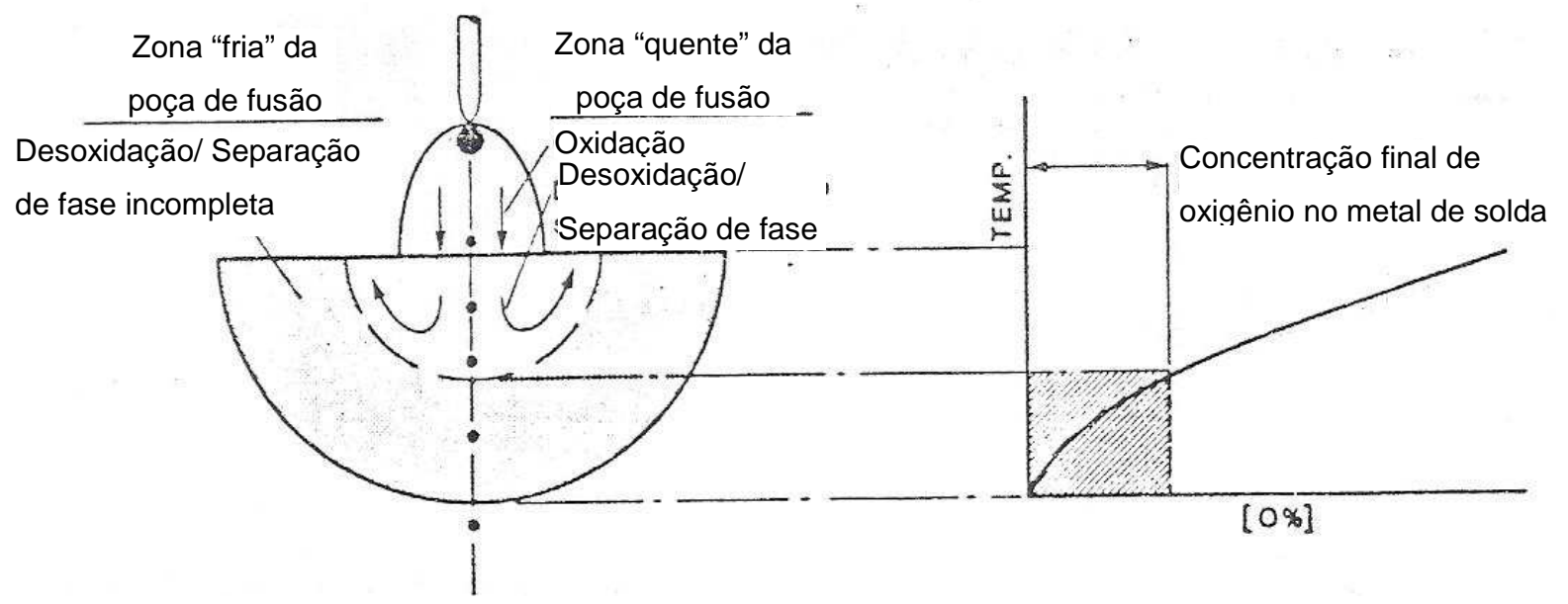

Figura 2.22: Reações durante a desoxidação do metal de solda. O gráfico à direita indica o teor de oxigênio para as diferentes faixas de temperaturas ao longo do centro do arco de soldagem. [47]

A fronteira entre as zonas "fria" e "quente" da poça de fusão não é bem definida, no entanto depende das condições de soldagem tais como parâmetros de soldagem e fluxo. A concentração final de oxigênio é controlada pelo pseudo-equilíbrio local entre reagentes e escória precipitada na zona "quente" da poça de fusão.

\subsection{Soldagem por arco submerso}

\subsubsection{Histórico}

A utilização de um fluxo granulado juntamente com um arame eletrodo de alimentação contínua teve início em 1935 na fabricação de tubos e navios [52]. Entre 1939 e 1945, ocorreu a automatização do processo, intensificando assim seu uso. Isto permitiu a rápida construção de equipamentos pesados durante a II Guerra Mundial, sobretudo navios. Desta forma o processo se consolidou, e os principais desenvolvimentos realizados estão relacionados aos fluxos e equipamentos utilizados. 
A utilização de múltiplos arames na soldagem por arco submerso tem uma de suas primeiras referências datada 1954 [25]. No início da década de 1980, Ratzsch desenvolveu o processo no qual se utiliza dois arames para a soldagem por arco submerso de lado único.

No Brasil, o processo é utilizado principalmente na indústria de equipamentos metálicos tais como tubos, navios, perfis, plataformas marítimas, trocadores de calor e equipamentos pesados, assim como na recuperação de peças como cilindros de laminação e peças rodantes de tratores [52].

Atualmente, a soldagem por arco submerso é o método mais rápido e com melhor custo $x$ benefício para soldagem de vasos de pressão [53]. Para usos a baixas temperaturas ou criogênicas, são utilizados arames dos tipos 308, 308L, 316 ou 316L. No entanto, na soldagem por arco submerso é difícil manter os requisitos de impacto a temperaturas abaixo de $-196^{\circ} \mathrm{C}$.

\subsubsection{Processo}

Na soldagem por arco submerso, o arco elétrico é estabelecido entre o arameeletrodo e o metal a ser soldado. $O$ arco se estabelece submerso em uma camada de fluxo, desta forma a soldagem ocorre sem a produção de faíscas, luminosidades e respingos. Consequentemente, o processo possui elevado rendimento metalúrgico [52].

Os fluxos utilizados são projetados para suportar as elevadas correntes de soldagem usadas no processo [52]. Sua função é de proteger a poça de solda contra os gases da atmosfera (oxigênio e nitrogênio) e atuar como desoxidante (limpando o metal de solda e podendo modificar a composição química do metal de solda). Os fluxos podem ser divididos em:

- Aglomerados: constituídos de compostos minerais finamente moídos, a estes é adicionado um agente aglomerante, como o silicato de sódio ou de potássio; 
- Fundidos: constituídos dos mesmos compostos minerais dos fluxos aglomerados, mas com os ingredientes fundidos em forno para formar um "vidro metálico", o qual é depois reduzido a partículas granulares com as dimensões requeridas para assegurar as características necessárias à soldagem.

Os eletrodos utilizados na soldagem por arco submerso são fabricados por trefilação e possuem faixas de composições químicas especificadas [52]. São em geral cobreados a fim de evitar oxidação em sua superfície durante o armazenamento.

Durante o processo de soldagem, o calor produzido pelo arco elétrico funde parte do fluxo e a ponta do eletrodo [52]. Desta forma, a zona de soldagem fica protegida pelo fluxo escorificante (fundido) e também por uma camada de fluxo não fundido. $O$ fluxo, na forma de grânulos, atua como fundente, além de proteger o metal de solda contra contaminações e atuar como isolante térmico, concentrando o calor na parte sólida. Ao se deslocar o eletrodo ao longo da junta, o fluxo fundido na forma de escória sobrenada e se separa do metal de solda. O metal de solda, o qual possui um ponto de fusão superior ao da escória, solidifica-se enquanto a escória permanece líquida. Desta forma, a escória protege o metal de solda recémsolidificado do oxigênio e do nitrogênio provenientes da atmosfera. Após a solidificação da escória, remove-se esta e o fluxo não fundido. O esquema do processo se encontra na figura 2.22 .

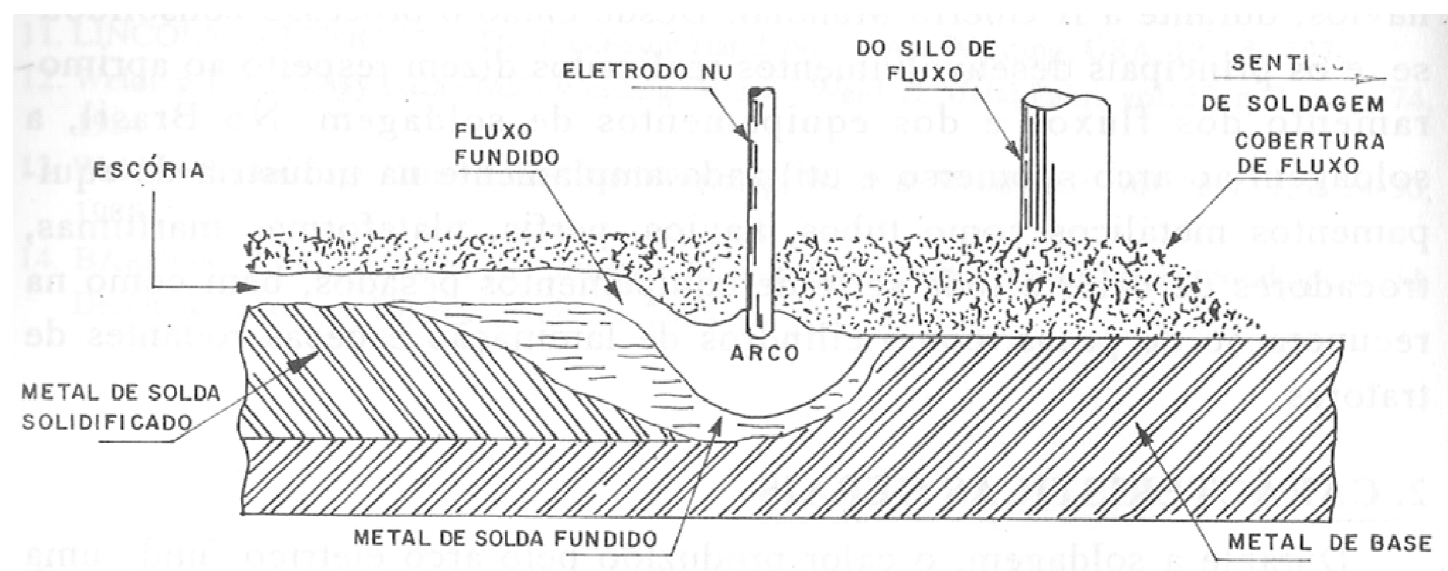

Figura 2.23: Soldagem por arco submerso. [52] 
A soldagem por arco submerso pode ser semi ou totalmente automática [52]. Em ambas o eletrodo é alimentado de um rolo até a pistola ou cabeçote de soldagem. $\mathrm{O}$ fluxo é alimentado por gravidade, caindo à frente do eletrodo ou concentricamente a ele. Desta forma, o fluxo e o eletrodo podem ser alterados a qualquer momento, diferentemente de outros processos com eletrodos revestidos. Além disso, o processo permite o uso de uma ampla faixa de intensidade de corrente, tensão e velocidade de avanço.

O processo pode ser realizado com corrente de elevadas intensidades (acima de $2000 \mathrm{~A}$ ) e altas densidades de corrente (de 60 a $100 \mathrm{~A} / \mathrm{mm}^{2}$ ) [52]. Desta forma, há elevada taxa de deposição, tornando o processo econômico e rápido. Em geral, o tempo médio gasto pelo processo é de um terço em relação à soldagem por eletrodos revestidos.

Sua maior desvantagem é, no entanto, o processo ser obrigatoriamente realizado na posição plana ou horizontal, pois a camada de fluxo sobre a poça é sustentada pela ação da gravidade [52].

\subsubsection{Equipamentos}

Os componentes básicos do equipamento de soldagem por arco submerso podem ser observados esquematicamente na figura 2.23 . 


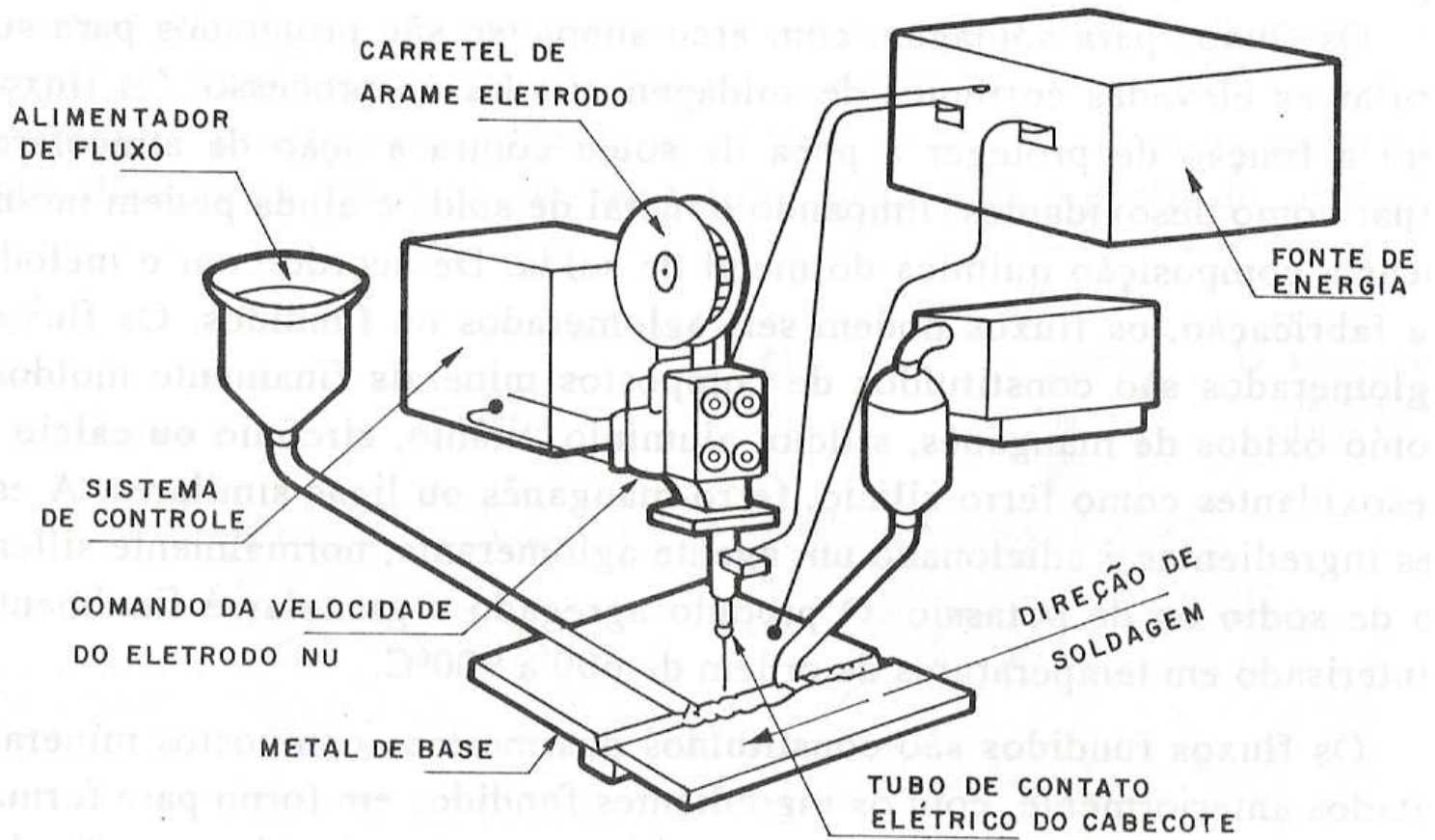

Figura 2.24: Esquema dos componentes básicos do equipamento de soldagem por arco submerso. [52]

Para a utilização de corrente contínua na soldagem, as fontes de energia podem ser do tipo gerador ou transformador-retificador [52]. Para corrente alternada, utilizase transformador. As fontes de energia devem ter capacidade de 600 a $1500 \mathrm{~A}$, sendo que fontes de menor capacidade podem ser ligadas em paralelo. Nelas, o controle pode ser:

- Tensão constante: mais utilizadas que a soldagem em corrente constante, a tensão é pré-determinada e o sistema corrige automaticamente a velocidade de alimentação do eletrodo, mantendo desta forma a tensão constante. A intensidade de corrente é ajustada na fonte de energia.

- Corrente constante: a intensidade é pré-determinada, mantendo-se assim a velocidade de alimentação do eletrodo constante. A tensão aplicada é ajustada na fonte de energia.

O cabeçote de solda é composto por motor-redutor, rolos de compressão, guias para alimentar o eletrodo à peça a ser soldada e tubo de contato elétrico, o qual transmite a corrente ao eletrodo [52]. 
O fluxo é alimentado através de um reservatório acoplado à tocha ou cabeçote, o qual alimenta continuamente o sistema [52]. O movimento deste se dá por duas maneiras: o cabeçote se movimenta sobre a peça a ser soldada ou a peça se move e o cabeçote permanece fixo.

Os equipamentos podem ser:

- Arco submerso semi-automático: o soldador empunha a tocha a qual conduz o eletrodo e possui um recipiente contendo o fluxo. Os controles dos parâmetros de soldagem são realizados na fonte, exceto a velocidade de avanço, a qual é determinada pelo movimento da mão do soldador;

- Arco submerso automático: o operador guia o cabeçote sobre a junta a ser soldada. Os controles se encontram em um painel, geralmente acoplado ao cabeçote;

- Arco submerso geminado: a soldagem é realizada simultaneamente por dois eletrodos nus acoplados a um mesmo cabeçote e utilizando a mesma fonte de energia. $O$ processo é normalmente utilizado para a execução de revestimentos devido a sua baixa diluição e pequena penetração;

- Arco submerso tandem com dois ou três eletrodos: diferentemente do arco submerso geminado, os eletrodos são acoplados em cabeçotes separados, formando assim arcos elétricos distintos ligados a fontes de energia separadas. Em geral, o $2^{\circ}$ e $\circ 3^{\circ}$ eletrodos são acoplados a fontes de corrente alternada;

- Arco submerso para soldagem com fita: ideal para revestimentos, pois permite cordões de solda com até $100 \mathrm{~mm}$ de largura. O equipamento utiliza um cabeçote o qual conduz uma fita com 30 a $100 \mathrm{~mm}$ de largura como eletrodo, fornecendo devido a esta largura penetração e diluição baixas e elevada taxa de deposição. 
A utilização de processos com mais de um arame leva a um aumento de produtividade através de uma maior velocidade de soldagem, bem como a uma menor adição de calor e reduzido potencial de distorção da peça [25].

\subsubsection{Parâmetros do processo}

A corrente elétrica determina a taxa de deposição, a profundidade de penetração da poça de solda no metal de base e a quantidade de metal de base fundido. Mantendo-se os demais parâmetros constantes, ao se elevar a corrente aumenta-se a penetração e a taxa de deposição. Deve-se salientar a importância da corrente escolhida, que deve estar dentro da faixa adequada para o diâmetro do eletrodo utilizado: uma corrente muito elevada produz um cordão muito alto e estreito, bem como a formação de mordeduras; uma corrente muito baixa produz um arco instável. Além disso, em soldas de passe simples a corrente deve proporcionar uma penetração desejada sem perfuração da junta; em soldas de passes múltiplos a corrente deve proporcionar a quantidade de enchimento desejada [52].

A tensão do arco influencia o formato da seção transversal do cordão e a aparência da solda [52]. Mantendo-se os demais parâmetros constantes, o aumento da tensão leva a: um cordão mais plano e largo; ao aumento do consumo de fluxo; a diminuição da porosidade (proveniente da oxidação ou presença de óleos não removidos); ao aumento do teor de liga oriundo do fluxo. Tensões excessivamente altas levam à formação de cordão em forma de chapéu, o qual é susceptível a trincas, dificulta a remoção da escória e, em soldas de passes múltiplos, aumentam o teor de liga do depósito e a sensibilidade à trinca.

Caso se mantenha os demais parâmetros constantes, o aumento do diâmetro do eletrodo aumenta a largura do cordão e diminui a densidade da corrente, a penetração e a taxa de deposição [52]. Desta forma, ao se utilizar um eletrodo mais grosso, pode-se suportar mais corrente e, assim, utilizar maiores intensidades e taxas de deposição mais elevadas. O diâmetro do eletrodo nos equipamentos automáticos de soldagem por arco submerso varia, em geral, entre 2,4 a 6,4 mm. 
Outro parâmetro no processo é o tipo de corrente utilizado [52]. A corrente contínua polaridade reversa - CCPR (+) - é a mais recomendada para a maioria das aplicações na soldagem por arco submerso, pois nela uma rápida seqüência de deposição de passes ou penetração total são fatores importantes. Além disso, a $\operatorname{CCPR}(+)$ leva a uma redução na porosidade e melhoria do formato do cordão de solda, conforme se observa na figura 2.24.

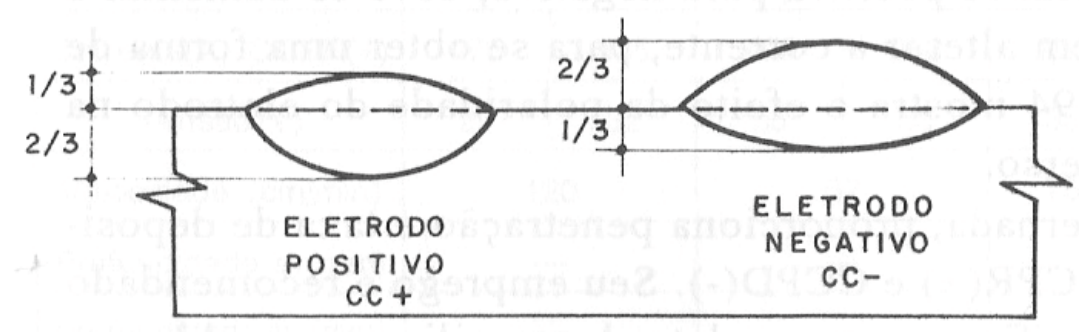

Figura 2.25: Cordão de solda para diferentes polaridades do eletrodo (positiva e negativa). [52]

A utilização de corrente contínua polaridade direta - CCPD (-) - permite uma taxa de deposição aproximadamente $30 \%$ maior que a obtida com CCPR (+), mas com menor penetração [52]. Devido a isto, ela é utilizada na soldagem de juntas em ângulo, onde a chapa é limpa e livre de contaminações, em soldas de revestimento (onde uma taxa de deposição elevada é vantajosa) e onde a baixa penetração é necessária para reduzir a diluição em aços de difícil soldabilidade evitando, desta forma, a formação de trincas e poros.

O uso de corrente alternada leva a uma penetração e a uma taxa de deposição intermediária entre CCPR (+) e CCPD (-), e é recomendado para os eletrodos auxiliares na soldagem tandem e quando ocorre sopro magnético ou apagamento do arco ao se utilizar corrente contínua [52]. Sua utilização também é recomendada para soldagens com velocidades de avanço muito baixas.

Há a soldagem com corrente alternada de onda quadrada com balanceamento variável (controle de formato de onda), que produz pulsos tanto em CCPR (+) quanto em CCPD (-), com diferentes tempos em cada polaridade [54]. Esta variante é diferente da soldagem por arco submerso em corrente alternada tradicional (que 
possui um sinal de onda senoidal com 50\% CCPR e 50\% CCPD). Por ter o formato de onda quadrada, os transientes que ocorrem durante a soldagem são minimizados quando comparados com o formato de onda senoidal. O período em CCPR (+) do ciclo pré-aquece mais a chapa que o eletrodo, permitindo uma penetração mais profunda. O período em CCPD (-) do ciclo pré-aquece mais o eletrodo que a chapa, fundindo o eletrodo mais rapidamente e aumentando a taxa de deposição [54].

Estudos comparativos entre soldagens por arco submerso tandem em CCPR (+), CCPD (-) e corrente alternada com controle de formato de onda [55] indicam que na polaridade direta a produtividade aumenta dramaticamente. Isto ocorre devido à vantagem do aquecimento do eletrodo no período de CCPD (-) e à estabilidade do arco oriunda dos controles de onda.

Outro parâmetro de soldagem é a velocidade de deslocamento da fonte de calor [52]. A velocidade de soldagem controla o tamanho do cordão, e está relacionada à intensidade da corrente. Para solda de passes múltiplos, a velocidade de soldagem deve levar ao tamanho do cordão desejado.

Ao se manter as demais condições constantes, uma velocidade excessivamente elevada reduz o molhamento, aumentando assim a tendência a mordeduras e apagamento do arco (levando a trincas e porosidades) [52]. Uma velocidade baixa de soldagem tende a reduzir a porosidade, pois os gases têm tempo suficiente para subir à superfície e saírem da solda ainda no estado líquido da mesma. No entanto, a soldagem com velocidade excessivamente baixa leva a cordões em forma de chapéu susceptíveis a trinca, assim como à formação de uma poça de fusão excessivamente grande em torno do arco elétrico, levando a um cordão rugoso, respingos e inclusões de escória.

Suutala [56] verificou que não ocorre alteração na penetração com aumento da velocidade de soldagem. Por sua vez, o formato da poça de fusão possui um formato de gota para velocidades maiores que $20 \mathrm{~cm} /$ minuto, e formato elíptico para velocidades menores, conforme a figura 2.25. 


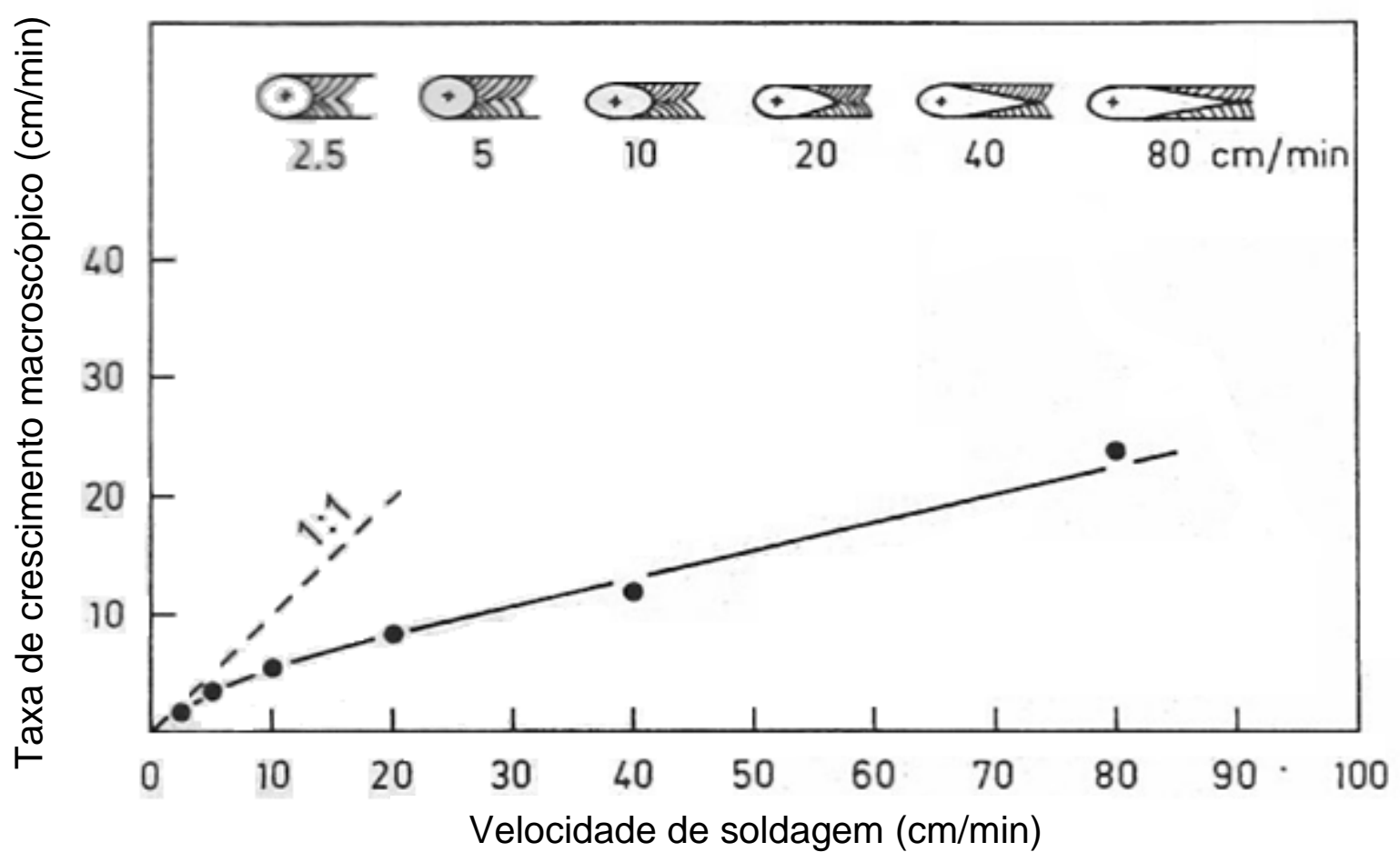

Figura 2.26: Efeito da velocidade de soldagem na velocidade de solidificação (próximo à linha de centro das soldas) e no formato da poça de fusão na soldagem TIG em CCPD (-). [56]

Ainda na figura 2.25 se verifica que a velocidade de solidificação é maior para maiores velocidades de soldagem. A velocidade de solidificação pode ser obtida através da equação:

$$
\mathrm{R}=v \cos \theta
$$

Onde $\mathrm{R}$ é a velocidade média de solidificação local, $v$ é a velocidade de soldagem e $\theta$ é o ângulo entre a direção de soldagem e a direção de crescimento das dendritas.

Suutala [56] também observou que um aumento na velocidade de soldagem favorece a formação de austenita primária (ou seja, um aumento na velocidade de solidificação favorece a formação de austenita), conforme se observa na tabela 2.5. Além disso, o número de ferrita decaiu em uma ou duas unidades com o aumento da velocidade de $2,5 \mathrm{~cm} /$ minuto a $80 \mathrm{~cm} /$ minuto. Estas influências, no entanto, são muito menores que as exercidas pela composição do metal no modo de solidificação do mesmo (a serem discutidas mais adiante). 
Tabela 2.5: Modos de solidificação em diferentes velocidades na soldagem TIG. Adaptado de [56].

\begin{tabular}{|c|c|c|c|c|c|c|}
\hline \multirow[b]{2}{*}{$\mathrm{Cr}_{\mathrm{eq}} / \mathrm{Ni}_{\text {eq }}$} & \multicolumn{3}{|c|}{$\begin{array}{l}\mathrm{AF}=\text { Austenítico-ferrítico (fração > 3/4) } \\
\mathrm{FA}=\text { Ferrítico-austenítico (fração >3/4) }\end{array}$} & & & \multirow[b]{2}{*}{80} \\
\hline & 2.5 & 5 & - & 20 & 40 & \\
\hline 1.38 & AF & AF & $\mathrm{AF}$ & $\mathrm{AF}$ & $\mathrm{AF}$ & $\mathrm{AF}$ \\
\hline 1.45 & $\mathrm{AF}$ & $\mathrm{AF}$ & $\mathrm{AF}$ & $\mathrm{AF}$ & $\mathrm{AF}$ & $\mathrm{AF}$ \\
\hline 1.49 & $\mathrm{AF}$ & $\mathrm{AF}$ & $\mathrm{AF}$ & $\mathrm{AF}$ & $\mathrm{AF}$ & $\mathrm{AF}$ \\
\hline 1.51 & AF & AF & AF & $\mathrm{AF}$ & $\mathrm{AF}$ & AF \\
\hline 1.54 & $\mathrm{AF}+\mathrm{FA}$ & $\mathrm{AF}+\mathrm{FA}$ & $\mathrm{AF}+\mathrm{FA}$ & $\mathrm{AF}$ & $\mathrm{AF}$ & $\mathrm{AF}$ \\
\hline 1.54 & FA & FA & $\mathrm{AF}+\mathrm{FA}$ & $\mathrm{AF}+\mathrm{FA}$ & AF & AF \\
\hline 1.54 & $\mathrm{FA}$ & FA & $\mathrm{AF}+\mathrm{FA}$ & $\mathrm{AF}+\mathrm{FA}$ & $\mathrm{AF}+\mathrm{FA}$ & $\Omega_{\mathrm{AF}}$ \\
\hline 1.55 & FA & FA & FA & FA & FA & $\mathrm{AF}+\mathrm{FA}$ \\
\hline 1.57 & FA & FA & FA & FA & FA & FA \\
\hline 1.61 & $\mathrm{FA}$ & FA & FA & FA & FA & FA \\
\hline
\end{tabular}

A região entre o ponto de contato elétrico e a ponta do eletrodo é aquecida devido à resistência elétrica durante a passagem de corrente elétrica. Esta distância é outro parâmetro da soldagem, sendo que seu aumento leva a uma maior taxa de deposição. Usualmente esta distância está compreendida entre 20 e 35 mm.

\subsubsection{Solidificação da poça de fusão}

Além dos parâmetros que controlam a solidificação em fundição, diversos processos físicos que ocorrem devido à interação da fonte de calor com o metal durante a soldagem controlam a microestrutura da solda [57].

$\mathrm{Na}$ soldagem, à medida que a fonte de calor interage com o material, as variações térmicas dão origem a três regiões distintas, conforme mostra a figura 2.26 a seguir:

1. Zona fundida (ZF): Região que é fundida durante o processo de soldagem, contendo tanto metal de base quanto metal de adição fundidos; 
2. Zona de ligação (ZDL): Região do metal de base imediatamente após a zona fundida, mas que permanece no estado sólido durante a soldagem. É a fronteira entre a zona fundida e a zona afetada pelo calor;

3. Zona afetada pelo calor (ZAC): Região do metal de base que permanece no estado sólido durante a soldagem, no entanto sofre modificações em suas propriedades mecânicas e microestruturais devido aos ciclos térmicos do processo;

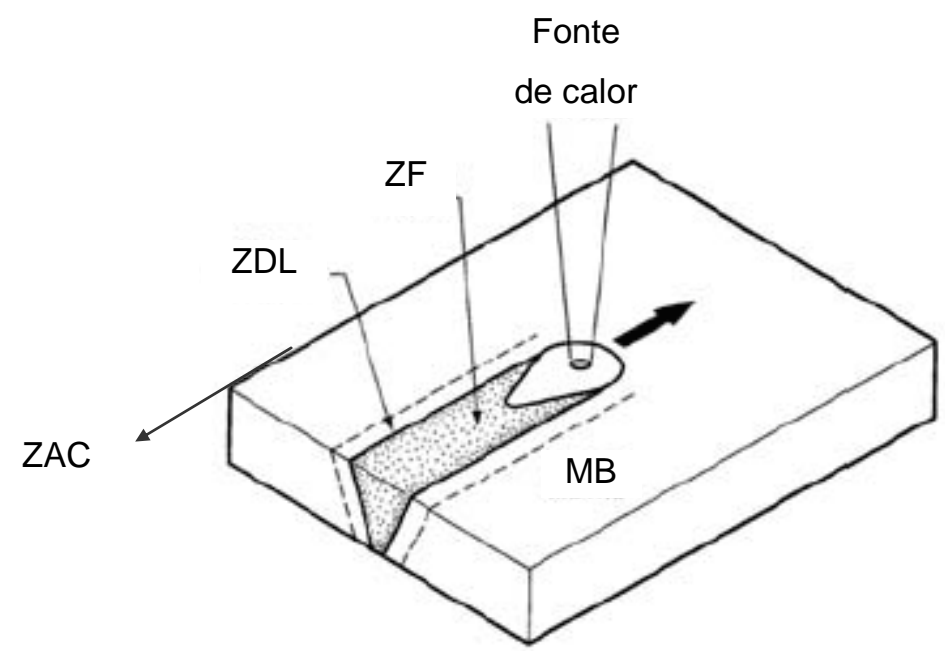

Figura 2.27: Regiões criadas pelos ciclos térmicos na soldagem: Zona de ligação, zona fundida e zona afetada pelo calor no metal de base - adaptado de [57].

A microestrutura desenvolvida na zona de fusão depende do balanço entre a energia introduzida na soldagem, da energia dissipada para a vizinhança da poça de fusão e da composição química. Os princípios de solidificação controlam o tamanho e a forma dos grãos, segregação e a distribuição de inclusões e porosidades [57].

Nos metais, a solidificação ocorre através da formação de um núcleo o qual se forma e pode crescer ou não, dependendo de seu tamanho. Caso a nucleação ocorra no interior do líquido (sem a interferência de fatores externos), a nucleação é chamada homogênea. Se ocorrer na presença de impurezas, inoculantes ou superfícies externas será então denominada heterogênea [52].

Ao se reduzir a temperatura do líquido, ocorre a transição do estado líquido para o sólido a uma temperatura de solidificação $T_{s}$. Quanto menor for o raio do sólido 
formado, menor será $T_{S}$, como se observa na figura 2.27. No entanto, para que a solidificação tenha início, é necessário um super-resfriamento em relação à Ts.

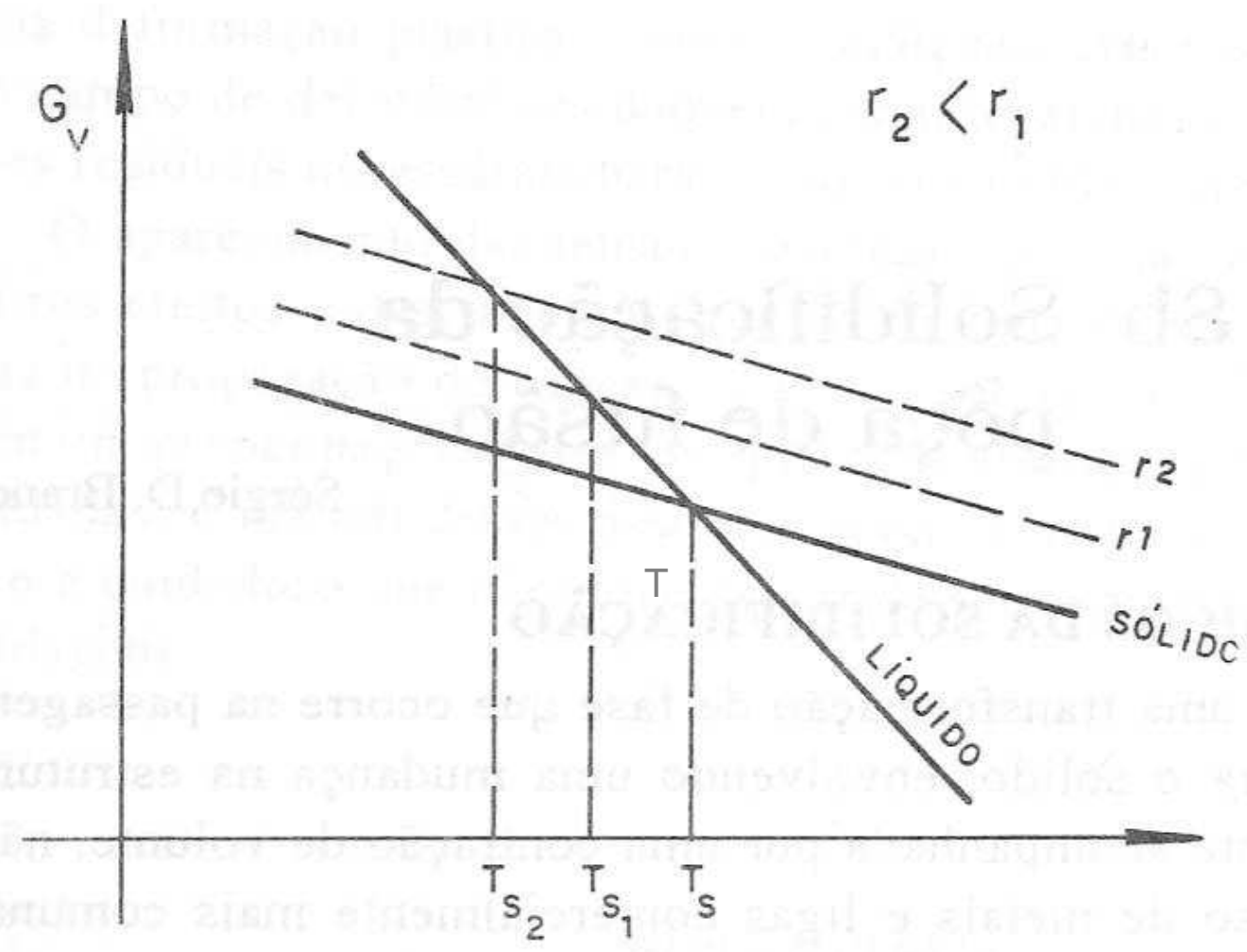

Figura 2.28: Energia livre por unidade de volume $\left(G_{v}\right)$ em função da temperatura $(T)$ para um metal puro - adaptado de [52].

\subsubsection{Solidificação de aços inoxidáveis austeníticos}

A morfologia e a fração volumétrica da ferrita no metal de solda são importantes para determinar o mecanismo de fratura a baixas temperaturas. O modo de solidificação, morfologia da ferrita e seu teor são determinados pela composição química (através da relação $\mathrm{Cr}_{\text {eq }} / \mathrm{Ni}_{\text {eq }}$ ) e pela orientação entre a direção (100)y e a direção do fluxo de calor durante a solidificação da poça de fusão [32, 58, 59, 60].

A figura 2.28 ilustra partes do diagrama ternário Cromo-Níquel-Ferro para 70\% e $60 \%$ Fe. Nela pode-se observar que ligas contendo altos teores de níquel solidificam 
como austenita, sendo que a ferrita solidifica nas regiões interdendríticas (figura 2.29 (a)). Para uma composição intermediária de níquel e cromo, inicialmente as dendritas solidificam como ferrita e, durante o resfriamento, ocorre formação de austenita + ferrita (figura 2.29 (b)). Para baixos teores de níquel, as dendritas solidificam inicialmente como ferrita e então se transformam em austenita + ferrita já no estado sólido, conforme a figura 2.29 (c).

(a)

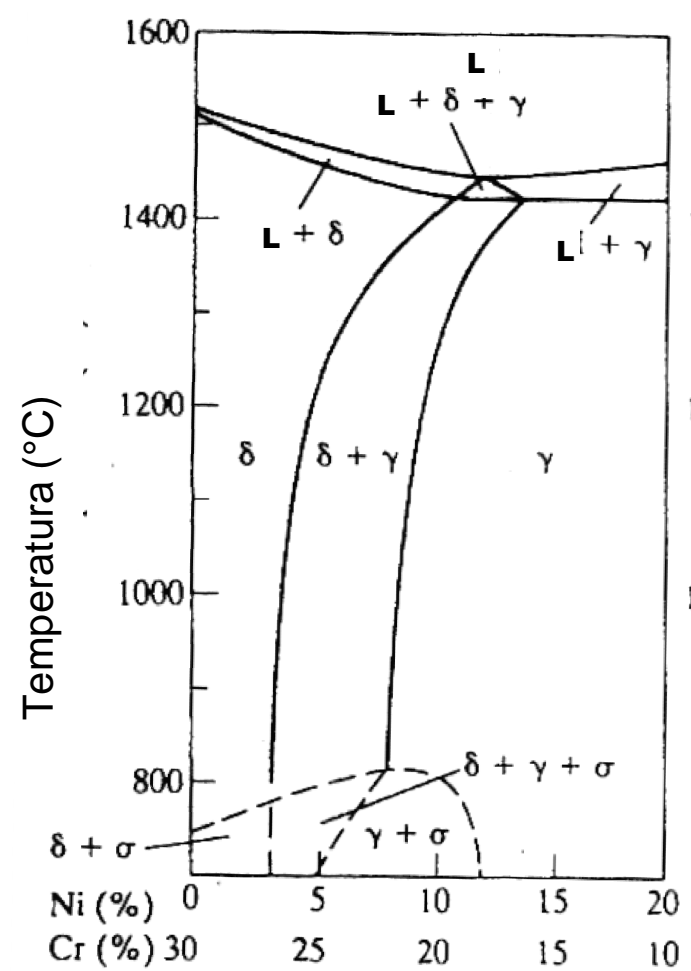

(b)

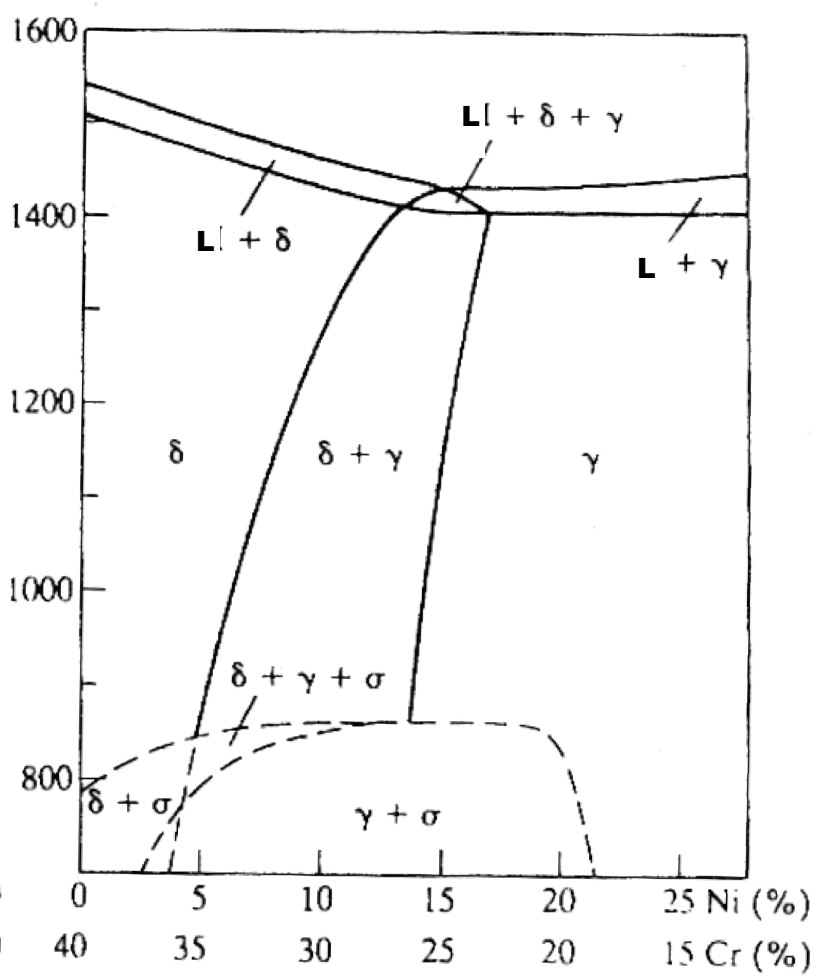

Figura 2.29: Regiões do diagrama ternário Cr-Ni-Fe para 70\% Fe (a) e 60\% Fe (b) (Schafmeister e Ergang, 1939). [61] 


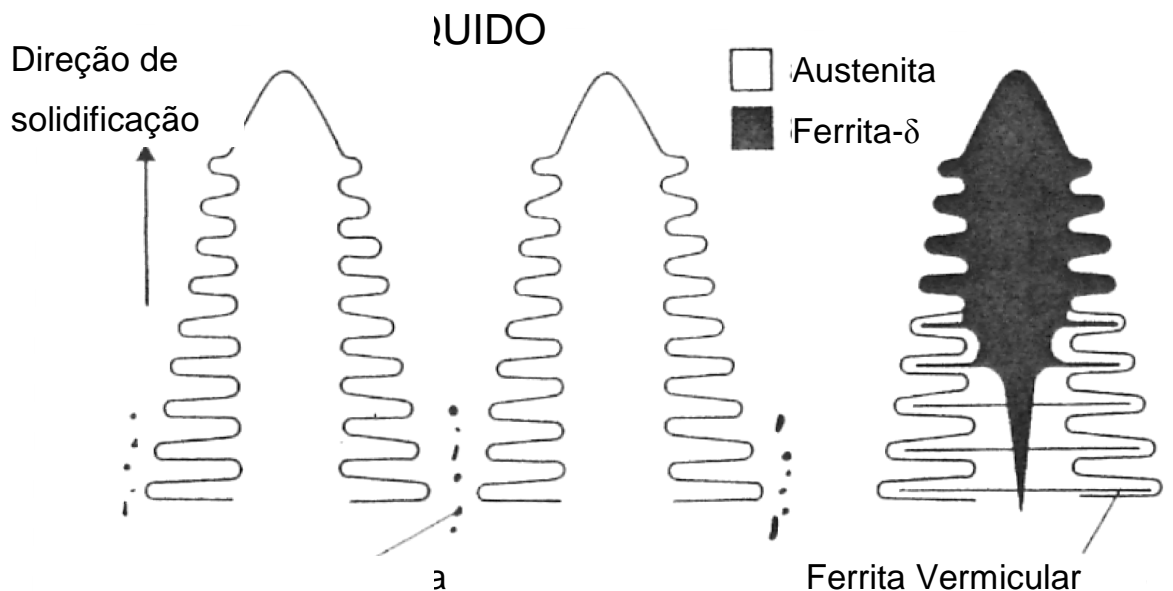

(a)

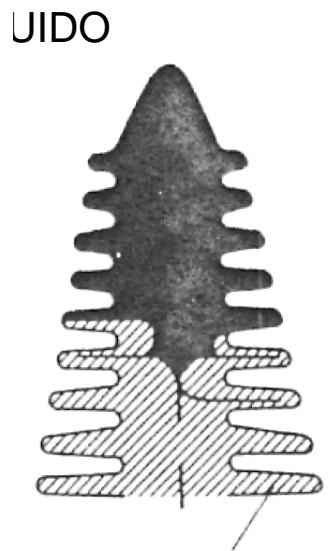

Ferrita acicular

(c)

Figura 2.30: Morfologias de solidificação da aços inoxidáveis austeníticos: austenita primária com ferrita interdendrítica (a); reação peritética (b) e transformação de ferrita primária a austenita + ferrita abaixo da temperatura solidus (c). [37]

Na figura 2.28, a região ferrítica abaixo da linha solidus é extensão da região de ferrita delta no diagrama Fe-C e, por esta razão, a ferrita em aços inoxidáveis austeníticos é denominada ferrita delta. A partir do diagrama de equilíbrio, pode-se esperar que a ferrita possua alto teor de cromo e baixo teor de níquel, o que efetivamente ocorre.

A fim de se prever os efeitos dos formadores de ferrita e austenita a temperaturas próximas da solidificação, Hammar e Svenson propuseram novos valores para se obter os teores de $\mathrm{Cr}_{\text {eq }}$ e $\mathrm{Ni}_{\text {eq }}[37,62]$ :

$$
\begin{aligned}
& \mathrm{Cr}_{\text {eq }}=\mathrm{Cr}+1,37 \mathrm{Mo}+1,5 \mathrm{Si}+2 \mathrm{Nb}+3 \mathrm{Ti} \\
& \mathrm{Ni}_{\text {eq }}=\mathrm{Ni}+0,31 \mathrm{Mn}+22 \mathrm{C}+14,2 \mathrm{~N}+\mathrm{Cu}
\end{aligned}
$$

O método proposto por Hammar e Svenson apresenta boa aproximação para soldagem de aços da série AISI 300 contendo nitrogênio como elemento de liga. Quando o teor de manganês está entre 5\% e 8\%, os cálculos de Hull se mostraram mais precisos em relação ao modo de solidificação e ao número de ferrita [62]:

$$
\begin{gathered}
\mathrm{Cr}_{\text {eq }}=\mathrm{Cr}+1,21 \mathrm{Mo}+0,48 \mathrm{Si}+0,14 \mathrm{Nb}+2,20 \mathrm{Ti}+0,72 \mathrm{~W}+0,21 \mathrm{Ta} \\
+2,27 \mathrm{~V}+2,48 \mathrm{Al} \\
\mathrm{Ni}_{\text {eq }}=\mathrm{Ni}+0,11 \mathrm{Mn}-0,0086 \mathrm{Mn}^{2}+24,5 \mathrm{C}+18,4 \mathrm{~N}+0,44 \mathrm{Cu}+0,41 \mathrm{Co}(2.25)
\end{gathered}
$$


A ferrita delta possui pelo menos duas morfologias distintas: curvada (vermicular) ou em forma de agulha (acicular) [63]. Em um cordão de solda pode existir apenas um destes tipos, no entanto comumente ambas coexistem na mesma solda. Takalo, Suutala e Moisio [63], consideram que a microestrutura em relação à ferrita delta pode ser considerada acicular caso mais de $90 \%$ da ferrita possua esta morfologia. Caso menos de $10 \%$ seja possua morfologia acicular, a microestrutura pode ser considerada vermicular. Os casos entre estes dois valores são considerados mistos.

A figura 2.30 mostra que existe uma relação entre a fração volumétrica de ferrita e a morfologia da ferrita delta. Quando o teor de ferrita é baixo (abaixo de 6\%), predomina a morfologia vermicular; quando o teor é alto (acima de 13\%), predomina a ferrita acicular. $\mathrm{Na}$ faixa intermediária entre $6 \%$ e $10 \%$ ocorrem ambas as morfologias.

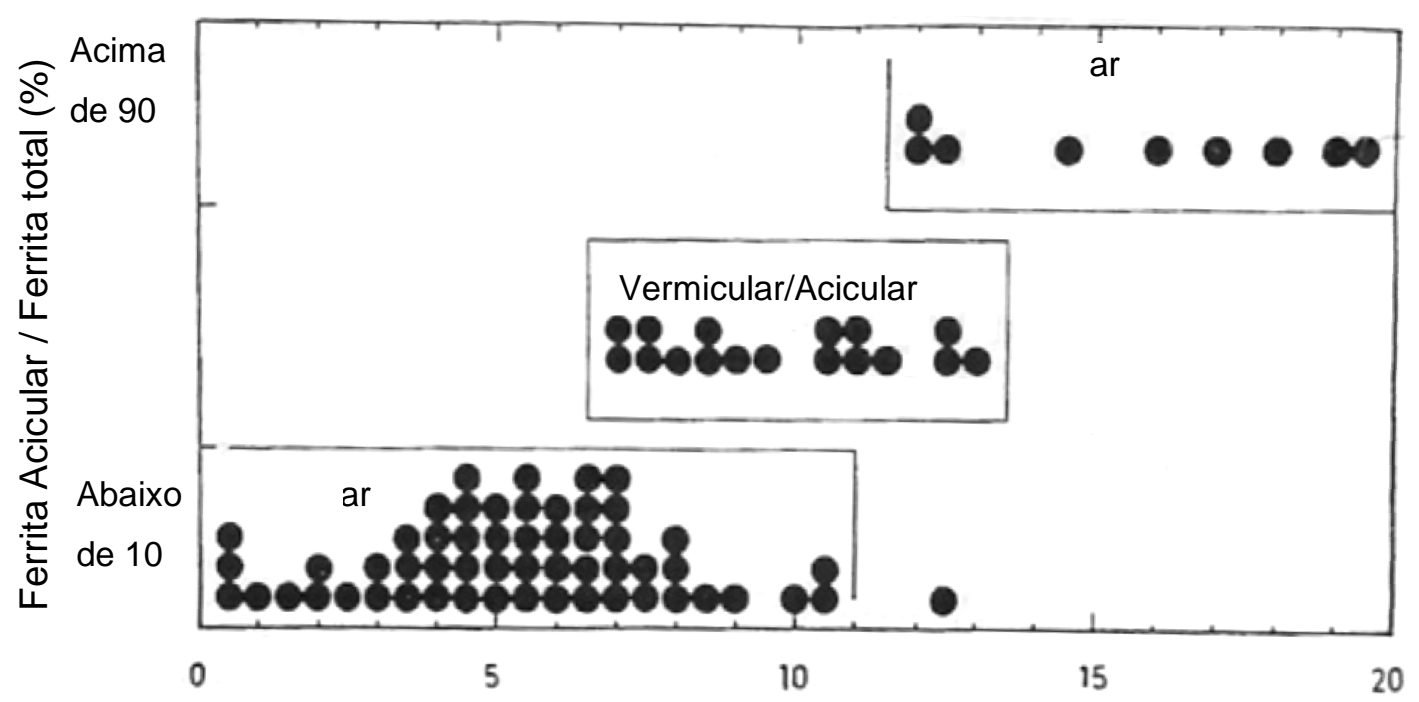

(\%)

Figura 2.31: Morfologia da ferrita em função da fração volumétrica da mesma. [63]

Os efeitos da composição química do aço inoxidável na morfologia da ferrita podem ser observados através da figura 2.31. 


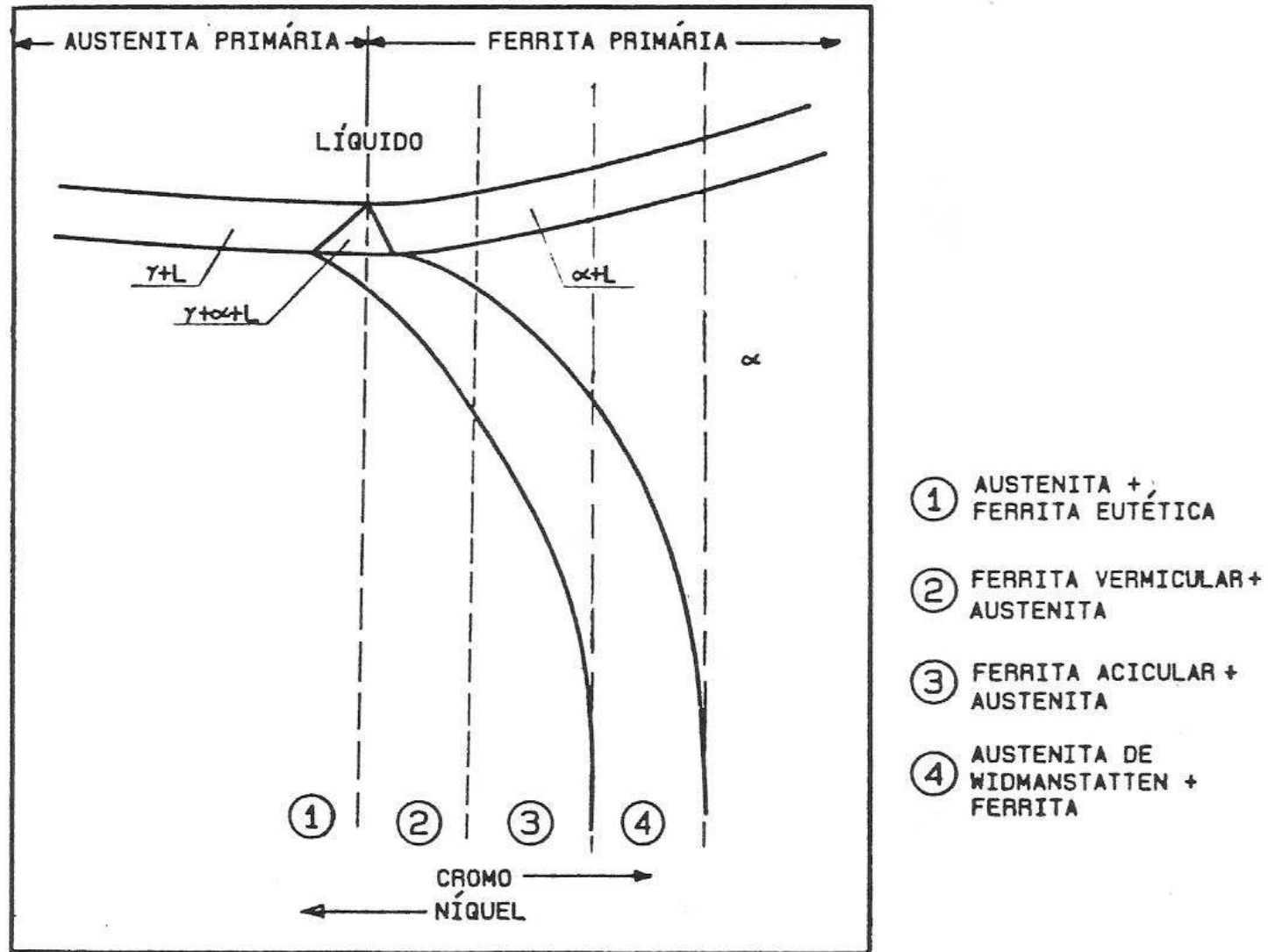

Figura 2.32: Efeito da composição química na morfologia da ferrita e da austenita no diagrama pseudo-binário Fe-Cr-Ni. [30]

- Na região 1 ocorre a formação de austenita primária. Caso ocorra formação de ferrita, esta ocorrerá nos contornos de grão. Se a proporção $\mathrm{Cr} / \mathrm{Ni}$ for suficientemente elevada para estabilizar a ferrita à temperatura ambiente, sua morfologia será semi-contínua.

- $\mathrm{Na}$ região 2, a solidificação tem início como ferrita primária. Durante o resfriamento no campo ferrítico + austenítico, pode ocorrer transformação de ferrita em austenita devido à alta velocidade de resfriamento no centro do cordão de solda.

- Na região 3, o início da solidificação é similar ao da região 2, mas a ferrita é estável por um intervalo de tempo maior, reduzindo o gradiente de composição química no estágio transiente inicial devido à difusão ser 
muito mais rápida na ferrita. Durante o resfriamento, novamente ocorre a transformação de ferrita em austenita, gerando uma microestrutura contendo ferrita acicular.

- Na região 4, não ocorre grande transformação de ferrita em austenita, sendo que a transformação é controlada por difusão e decomposição da ferrita em austenita de Widmanstatten. À temperatura ambiente, apresenta equilíbrio entre as quantidades de ferrita e austenita, além de apresentarem tamanho de grão maior por permanecerem ferríticos por um intervalo de tempo maior durante o resfriamento [30].

A morfologia da ferrita varia alterando-se a relação $(\mathrm{Cr} / \mathrm{Ni})_{\text {eq }}$, de forma que muda o modo de solidificação. Nos aços inoxidáveis austeníticos, existem basicamente três modos de solidificação na soldagem alterando-se a relação $(\mathrm{Cr} / \mathrm{Ni})_{\text {eq }}$ : ferrita primária, ferrítico-austenítico e austenita primária. Desta maneira, é possível dividir sua microestrutura e a morfologia da ferrita em $[22,27,28,64,65,66]$ :

- $(\mathrm{Cr} / \mathrm{Ni})_{\text {eq }}<1,48 \rightarrow$ austenita primária (tipo $\left.\mathrm{A}\right)$. A ferrita delta, se existente, é vermicular e se localiza nos contornos entre diferentes substratos de solidificação;

- $1,48<(\mathrm{Cr} / \mathrm{Ni})_{\text {eq }}<1,95 \rightarrow$ ferrítica-austenítica (tipo B). Tanto ferrita vermicular quanto ferrita acicular estão presentes. A ferrita delta se encontra, principalmente, nos eixos das células;

- $(\mathrm{Cr} / \mathrm{Ni})_{\text {eq }}>1,95 \rightarrow$ ferrita primária (tipo C). Predomina a ferrita acicular.

Esta classificação está de acordo com a classificação proposta anteriormente e ilustrada na figura 2.31, sendo que o tipo $A$ corresponde à região 1 , o tipo $B$

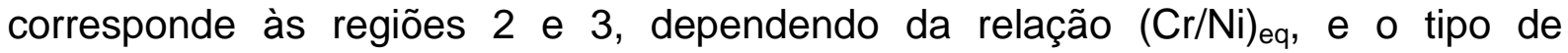
solidificação $C$ corresponde à região 4 . Por outro lado, se $(\mathrm{Cr} / \mathrm{Ni})_{\text {eq }}>2,3$, o tipo $C$ corresponderá à região 4 . As microestruturas em função das relações $(\mathrm{Cr} / \mathrm{Ni})_{\text {eq }}$ estão esquematizadas na figura 2.32 . 


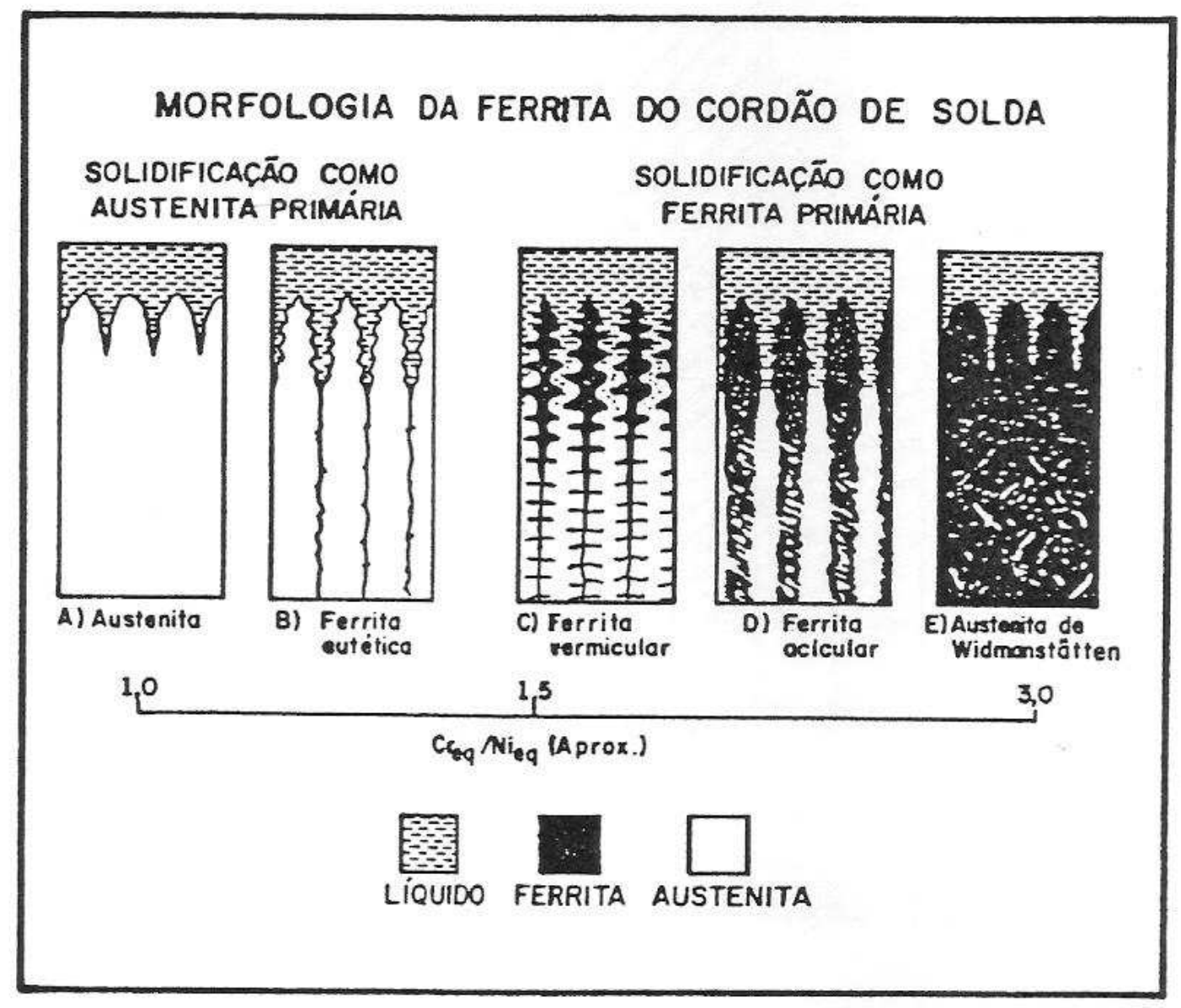

Figura 2.33: Microestrutura de solidificação em função da relação (Cr/Ni)equiv. [65, 66]

As seguintes observações foram feitas em estudos anteriores [22, 27, 28, 65] destas três microestruturas de solidificação:

A microestrutura do tipo $\mathrm{A}$ é muito regular devido à estrutura de solidificação, e independe da presença de ferrita delta. As células de austenita crescem na direção [100]. Células com aproximadamente a mesma direção de crescimento formam um bloco, o qual corresponde a um grão de austenita. No entanto, em alguns grãos pode haver mais de um bloco, pois a direção [100] pode mudar por razões cinéticas. A ferrita possui, se existente, um caráter vermicular e sempre se localiza entre células ou dendritas celulares, conforme a figura 2.33. 


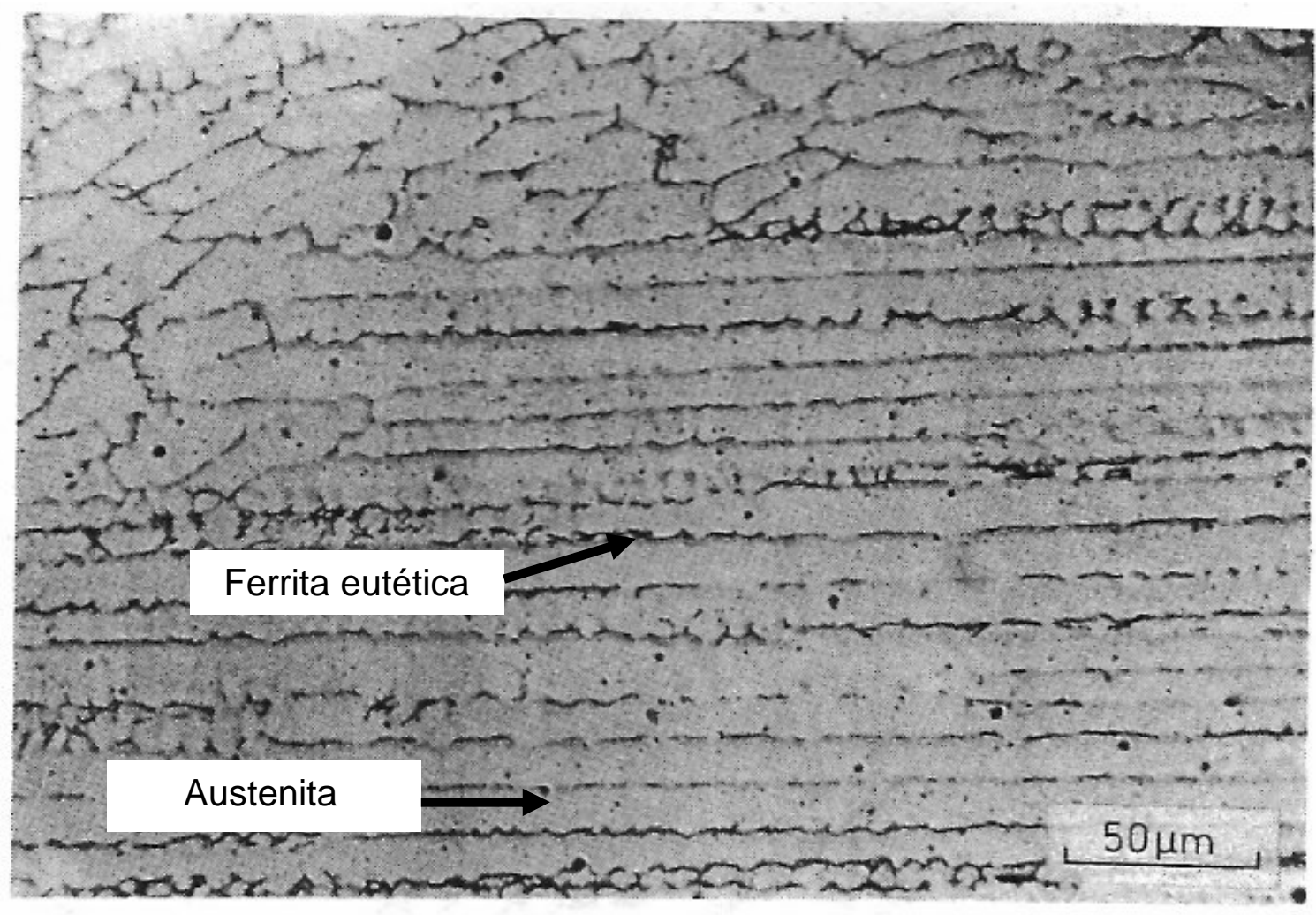

Figura 2.34: Região de aço inoxidável austenítico com microestrutura do tipo $A-(\mathrm{Cr} / \mathrm{Ni})_{\text {eq }}<1,48$ : Apresenta predominância de austenita. A ferrita presente apresenta morfologia eutética. [65]

Durante a transformação $\delta \rightarrow \gamma$, o teor de ferrita diminui abaixo da temperatura solidus. Esta redução é provavelmente pequena nas soldas do tipo $A$, uma vez que a ferrita delta possui uma composição estável devido a efeitos de segregação do $\mathrm{Ni}$ e Cr: enquanto $\mathrm{Cr}$ é expelido da região transformada em austenita, $\mathrm{Ni}$ é expelido da região ferrítica [28,67]. A solidificação em soldas do tipo A se distingue dos tipos $\mathrm{B}$ e $C$ devido ao baixo teor de ferrita, com formação de austenita primária.

Na microestrutura do tipo $C$, o teor de ferrita é muito maior que na microestrutura do tipo A. A estrutura apresenta grandes células contendo ferrita acicular, sendo a matriz ferrítica à temperatura ambiente. As células são, em geral, alongadas em uma direção paralela ao gradiente de temperatura e ao seu redor se encontra a austenita. Assim como na microestrutura do tipo $\mathrm{A}$, o crescimento das células ocorre em geral na direção [100], conforme a figura 2.34. 


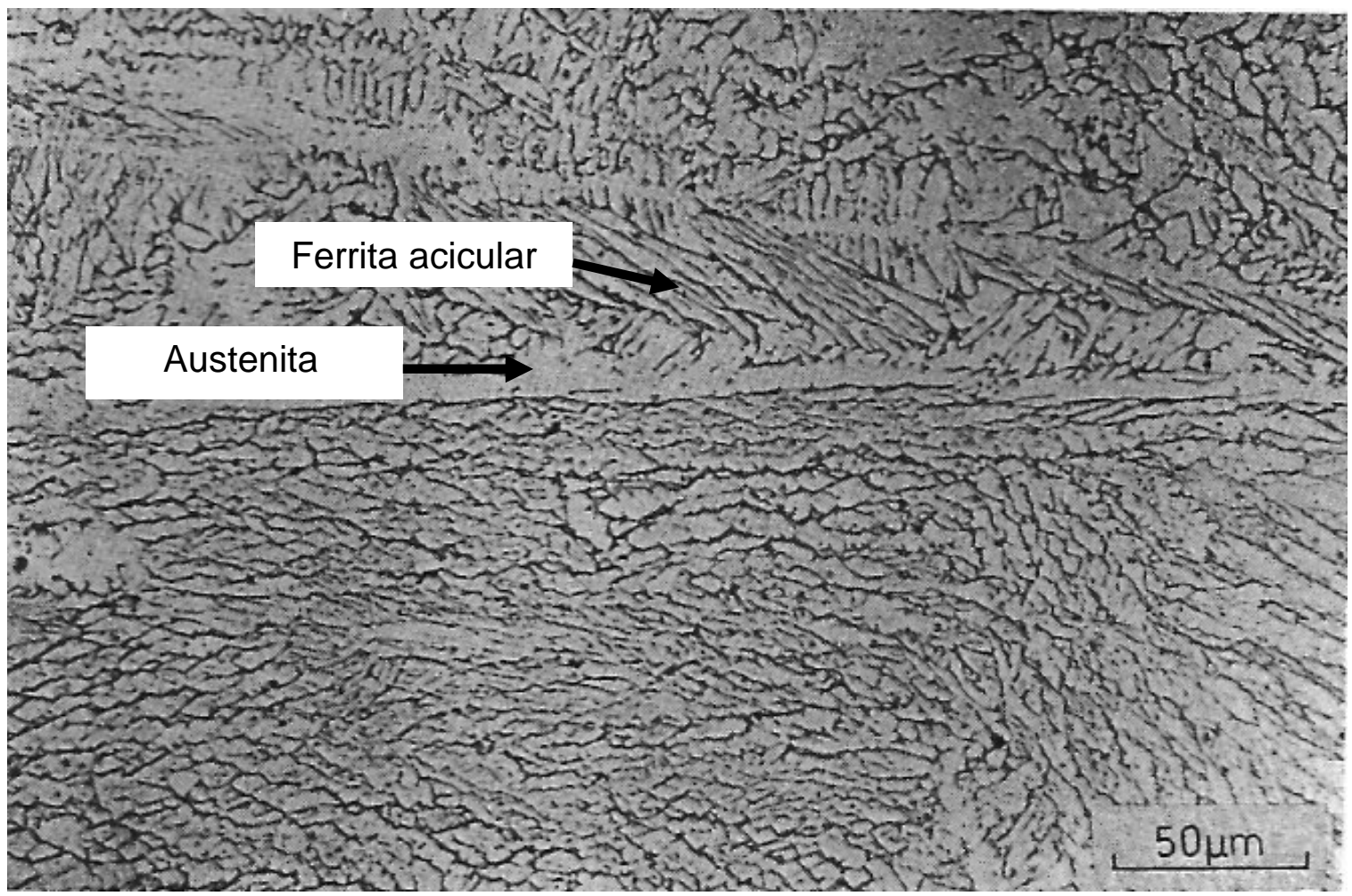

Figura 2.35: Microestrutura de aço inoxidável austenítico do tipo $\mathrm{C}-(\mathrm{Cr} / \mathrm{Ni})_{\mathrm{eq}}>1,95$ : Apresenta alto teor de ferrita de morfologia acicular. [65]

A ferrita delta existente em um metal de solda austenítico à temperatura ambiente não é uma fase estável, sendo resultado da ferrita retida que não se transformou em austenita durante o resfriamento. Sua estabilidade aumenta com o aumento da temperatura. Assim, a altas temperaturas seu teor aumenta - o mesmo ocorre com o aumento da relação $(\mathrm{Cr} / \mathrm{Ni})_{\text {eq. }}$. Desta forma, durante o resfriamento a austenita nucleia dentro das células ferríticas devido ao super-resfriamento. A formação da austenita ocorre em forma de agulhas paralelas à borda da célula, que podem coalescer com austenitas vizinhas formando uma microestrutura similar à de Widmanstätten.

As microestruturas do tipo B, por sua vez, apresentam um teor de ferrita intermediário entre as microestruturas dos tipos A e C. Suas microestruturas dependem da composição do metal: quando a relação $\mathrm{Cr}_{\mathrm{eq}} / \mathrm{Ni}_{\mathrm{eq}}$ é alta, a estrutura muitas vezes apresenta células com ferrita acicular cercada por austenita (figura 2.35). Quando a relação é baixa, a estrutura apresenta ferrita vermicular em uma matriz austenítica, como se observa na figura 2.36 . 


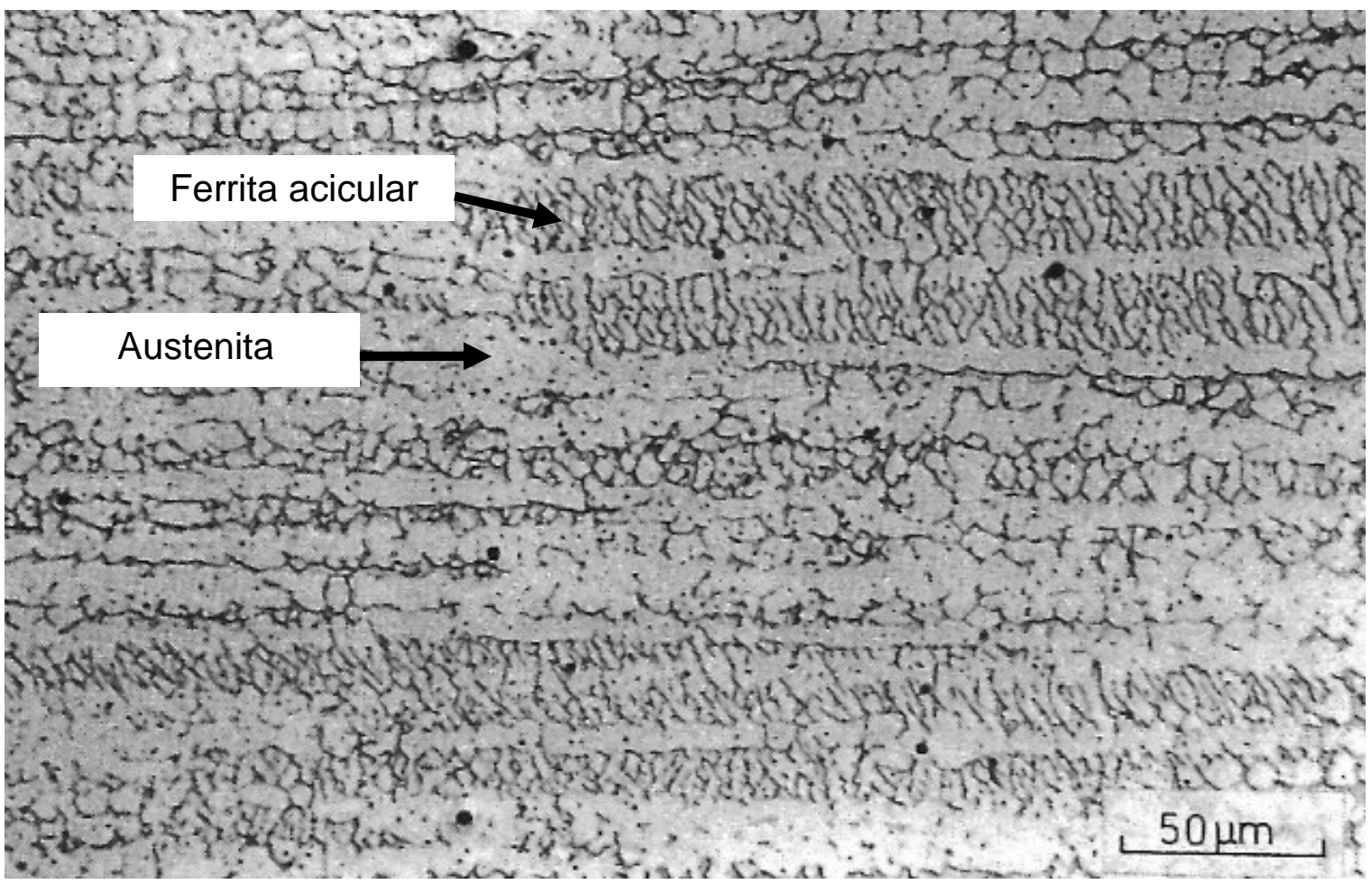

Figura 2.36: Microestrutura de aço inoxidável austenítico do tipo B $-1,48<(\mathrm{Cr} / \mathrm{Ni})_{\mathrm{eq}}<1,95$ - com alta relação Creq/Nieq: Presença de ferrita acicular cercada por austenita. [41]

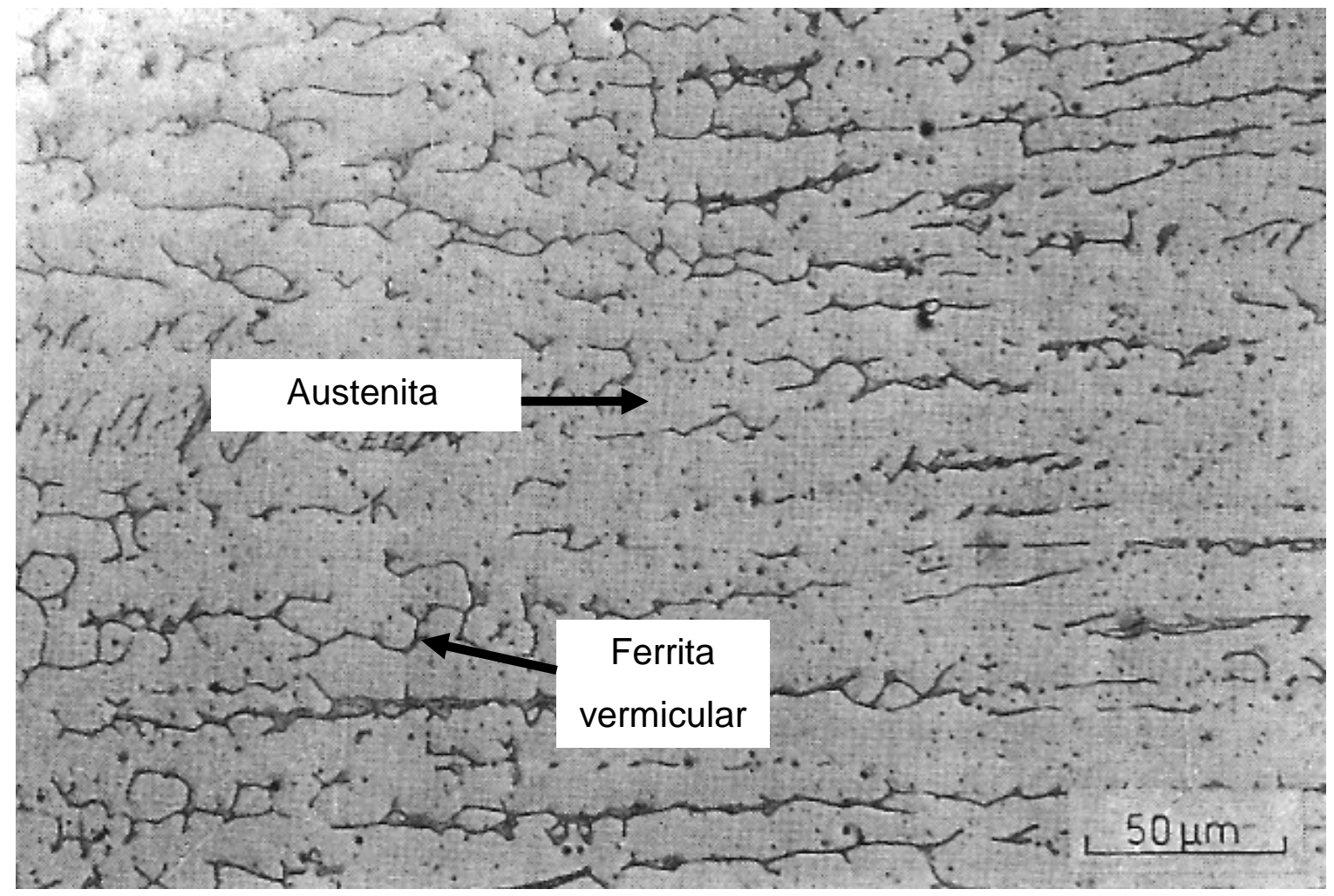

Figura 2.37: Microestrutura de aço inoxidável austenítico do tipo B - 1,48 $<(\mathrm{Cr} / \mathrm{Ni})_{\text {eq }}<1,95$ - com baixa relação Creq/Nieq: Presença de ferrita vermicular em uma matriz austenítica. [41] 
Com o aumento de $(\mathrm{Cr} / \mathrm{Ni})_{\text {eq, }}$, além do aumento da fração de ferrita também se torna necessário um maior super-resfriamento para iniciar a formação da austenita. Assim, para soldas do tipo $\mathrm{B}$, quando a relação $(\mathrm{Cr} / \mathrm{Ni})_{\text {eq }}$ é alta há maior fração de ferrita acicular à temperatura ambiente. Para valores mais baixos de $(\mathrm{Cr} / \mathrm{Ni})_{\text {eq }}$ há menor quantidade de ferrita, que neste caso é vermicular. Observou-se que a ferrita apresenta orientação [100], enquanto a austenita apresenta orientação [100] para baixos valores de $(\mathrm{Cr} / \mathrm{Ni})_{\text {eq }}$, e orientação [110] para maiores valores (ou seja, nos casos em que a austenita é proveniente da decomposição da ferrita, como na microestrutura do tipo C).

A relação $(\mathrm{Cr} / \mathrm{Ni})_{\text {eq }}$ não é o único fator determinante da morfologia da ferrita. Durante a solidificação ferrítico-austenítica, pode ocorrer formação de ferrita tanto vermicular quanto acicular caso a direção $\langle 100>$ y e a direção do fluxo de calor durante a solidificação da poça de fusão sejam paralelas [32]. Neste caso, a morfologia da ferrita dependerá da ocorrência ou não de relação de orientação de Kurdjumov-Sachs (KS) entre a ferrita delta e a austenita. No entanto, caso a direção $<100>$ Y e a direção do fluxo de calor durante a solidificação da poça de fusão não sejam paralelas, a ferrita será vermicular. 


\section{Materiais e métodos}

\subsection{Materiais empregados}

Neste trabalho foi realizada a soldagem por arco submerso em quatro corpos de prova, numerados de 1 a 4 . Foram soldados dois corpos de prova para a otimização dos parâmetros de soldagem. Todos tinham metal de base AISI 304 de $25 \mathrm{~mm}$ de espessura. A tabela 3.1 apresenta a composição química da chapa utilizada neste estudo.

Tabela 3.1: Composição química da chapa de aço AISI 304 utilizado na soldagem.

\begin{tabular}{|l|l|l|l|l|l|l|l|l|l|}
\hline Elemento & $\mathrm{C}$ & $\mathrm{Mn}$ & $\mathrm{Si}$ & $\mathrm{S}$ & $\mathrm{P}$ & $\mathrm{Ni}$ & $\mathrm{Cr}$ & $\mathrm{Mo}$ & $\mathrm{O}$ \\
\hline Teor $(\%)$ & 0,018 & 1,33 & 0,48 & 0,002 & 0,029 & 8,38 & 18,16 & 0,074 & 0,0039 \\
\hline Elemento & $\mathrm{Cu}$ & $\mathrm{Nb}^{(1)}$ & $\mathrm{Ti}$ & $\mathrm{N}$ & $\mathrm{Co}$ & $\mathrm{Al}$ & $\mathrm{B}$ & $\mathrm{V}$ & \\
\hline Teor $(\%)$ & 0,096 & 0,013 & 0,0056 & 0,053 & 0,063 & 0,003 & 0,0004 & 0,039 & \\
\hline
\end{tabular}

(1) $\mathrm{Nb}=\mathrm{Nb}+\mathrm{Ta}$

Conforme se observa na tabela acima, o teor de carbono medido no metal de base corresponde a uma chapa de aço AISI 304L, e não AISI 304. Isto ocorre pois, para redução de custos, é mais econômico produzir apenas uma das duas composições químicas ao invés de se produzir ambas. Assim, ao ser solicitada uma chapa em aço AISI 304, foi fornecida uma chapa em aço AISI 304L.

Utilizou-se na soldagem um arame ER 308L de diâmetro nominal de $3,2 \mathrm{~mm}$ (3,25 mm reais) e composição química conforme a tabela 3.2. 
Tabela 3.2: Composição química do arame ER 308L utilizado na soldagem.

\begin{tabular}{|l|c|c|c|c|c|c|c|c|}
\hline Elemento & $\mathrm{C}$ & $\mathrm{Mn}$ & $\mathrm{Si}$ & $\mathrm{S}$ & $\mathrm{P}$ & $\mathrm{Ni}$ & $\mathrm{Cr}$ & $\mathrm{Mo}$ \\
\hline Teor $(\%)$ & 0,015 & 1,92 & 0,32 & 0,01 & 0,017 & 9,68 & 19,63 & 0,09 \\
\hline Elemento & $\mathrm{Cu}$ & $\mathrm{Nb}^{(1)}$ & $\mathrm{Ti}$ & $\mathrm{N}$ & $\mathrm{Co}$ & $\mathrm{Al}$ & $\mathrm{B}$ & $\mathrm{V}$ \\
\hline Teor $(\%)$ & 0,06 & 0,01 & 0,01 & 0,055 & 0,04 & 0,005 & 0,0009 & 0,07 \\
\hline
\end{tabular}

(1) $\mathrm{Nb}=\mathrm{Nb}+\mathrm{Ta}$

Foram utilizados dois fluxos aglomerados distintos: um fluxo ligado (autocompensante em $\mathrm{Cr}$, cuja composição química é confidencial por ser um produto comercial) para os corpos de prova 3 e 4, e um fluxo neutro, ou seja, não adiciona elemento de liga ao metal de solda (classificação AWS A5.23 - a qual especifica fluxos e eletrodos de baixa liga para soldagem por arco submerso - F8P0-EB2-B2 de composição química de acordo com a tabela 3.3) para os corpos de prova 1 e 2.

Tabela 3.3: Composição química do fluxo neutro ME.

\begin{tabular}{|l|c|c|c|c|c|c|c|c|}
\hline Elemento & $\mathrm{C}$ & $\mathrm{Mn}$ & $\mathrm{Si}$ & $\mathrm{S}$ & $\mathrm{P}$ & $\mathrm{Cu}$ & $\mathrm{Cr}$ & $\mathrm{Mo}$ \\
\hline Teor $(\%)$ & 0,08 & 0,60 & 0,30 & 0,01 & 0,009 & 0,10 & 1,24 & 0,45 \\
\hline
\end{tabular}

\subsection{Parâmetros de soldagem}

Todos os corpos de prova foram soldados por arco submerso na posição plana. Foi realizada remoção do passe de raiz com lixadeira e a temperatura de préaquecimento foi a ambiente nos quatro corpos de prova.

A soldagem do corpo de prova número 1 foi realizada em corrente alternada de onda quadrada balanceada e frequência de onda de $70 \mathrm{~Hz}$ (utilizou-se esta frequência por ser usualmente utilizada na indústria). Foram necessários dois passes na parte inferior do chanfro (duas camadas) e cinco passes na parte superior do chanfro (quatro camadas), conforme ilustra a figura 3.1. Os parâmetros de soldagem de cada passe estão descritos na tabela 3.4. 


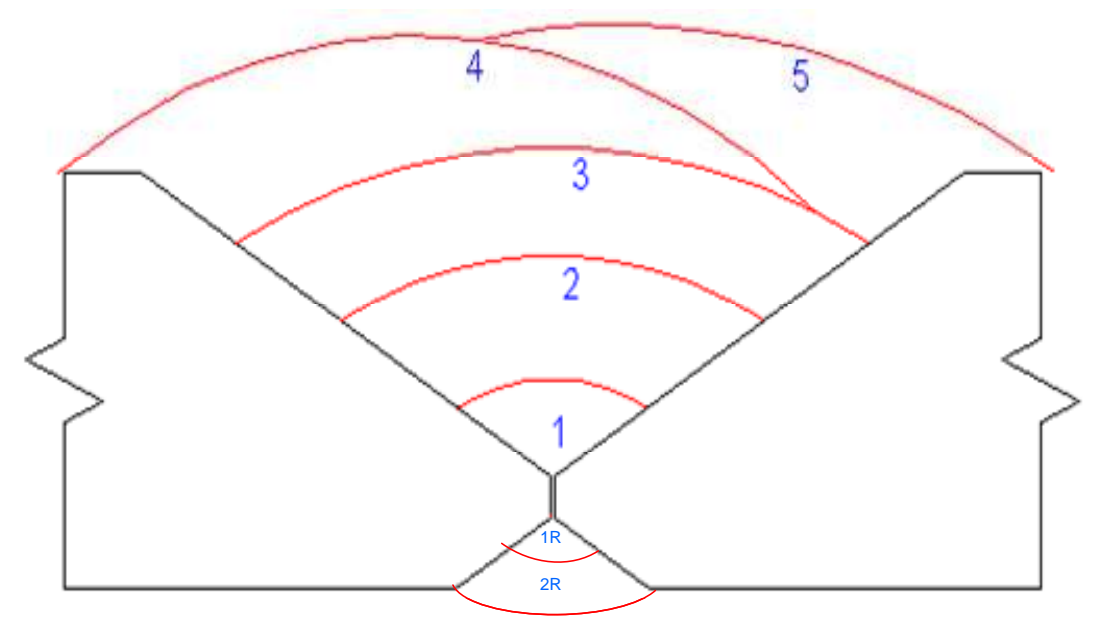

Figura 3.1: Passes de solda no corpo de prova 1.

Tabela 3.4: Parâmetros de soldagem do corpo de prova 1.

\begin{tabular}{|c|c|c|c|c|c|}
\hline Passe & $\begin{array}{c}\text { Corrente de } \\
\text { soldagem } \\
(\mathrm{A})\end{array}$ & $\begin{array}{c}\text { Tensão } \\
\text { do arco } \\
(\mathrm{V})\end{array}$ & $\begin{array}{c}\text { Velocidade } \\
(\mathrm{mm} / \mathrm{s})\end{array}$ & $\begin{array}{c}\text { Temperatura } \\
\text { interpasse } \\
\left({ }^{\circ} \mathrm{C}\right)\end{array}$ & $\begin{array}{c}\text { Energia de } \\
\text { soldagem } \\
(\mathrm{kJ} / \mathrm{mm})\end{array}$ \\
\hline 1 & 400 & 29 & 8,08 & $120<\mathrm{T}<140$ & 1,4 \\
\hline 2 & 480 & 30 & 8,10 & $120<\mathrm{T}<140$ & 1,8 \\
\hline 3 & 515 & 31 & 8,08 & $120<\mathrm{T}<140$ & 2,0 \\
\hline 4 & 535 & 31 & 7,92 & $120<\mathrm{T}<140$ & 2,1 \\
\hline 5 & 535 & 31 & 8,33 & $120<\mathrm{T}<140$ & 2,0 \\
\hline $1 \mathrm{R}$ & 545 & 31 & 8,33 & $120<\mathrm{T}<140$ & 2,0 \\
\hline $2 \mathrm{R}$ & 550 & 32 & 7,83 & $120<\mathrm{T}<140$ & 2,2 \\
\hline
\end{tabular}

Para o corpo de prova 2, realizou-se a soldagem com corrente contínua de polaridade reversa (CCPR+). Foi necessário um passe de solda no chanfro inferior e cinco passes no chanfro superior (quatro camadas), conforme indica a figura 3.2. Os parâmetros de soldagem estão na tabela 3.5. 


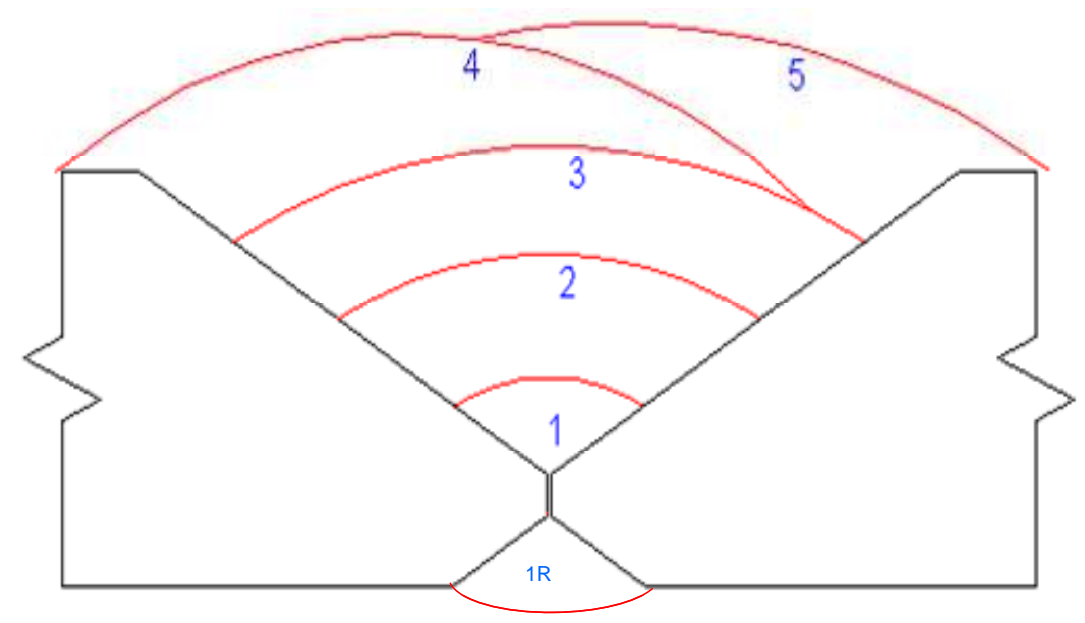

Figura 3.2: Passes de solda no corpo de prova 2.

Tabela 3.5: Parâmetros de soldagem do corpo de prova 2.

\begin{tabular}{|c|c|c|c|c|c|}
\hline Passe & $\begin{array}{c}\text { Corrente de } \\
\text { soldagem } \\
(\mathrm{A})\end{array}$ & $\begin{array}{c}\text { Tensão } \\
\text { do arco } \\
(\mathrm{V})\end{array}$ & $\begin{array}{c}\text { Velocidade } \\
(\mathrm{mm} / \mathrm{s})\end{array}$ & $\begin{array}{c}\text { Temperatura } \\
\text { interpasse } \\
\left({ }^{\circ} \mathrm{C}\right)\end{array}$ & $\begin{array}{c}\text { Energia de } \\
\text { soldagem } \\
(\mathrm{kJ} / \mathrm{mm})\end{array}$ \\
\hline 1 & 440 & 29 & 7,83 & $120<\mathrm{T}<140$ & 1,6 \\
\hline 2 & 540 & 30 & 7,83 & $120<\mathrm{T}<140$ & 2,1 \\
\hline 3 & 540 & 31 & 8,00 & $120<\mathrm{T}<140$ & 2,1 \\
\hline 4 & 540 & 31 & 8,00 & $120<\mathrm{T}<140$ & 2,1 \\
\hline 5 & 540 & 31 & 7,83 & $120<\mathrm{T}<140$ & 2,1 \\
\hline $1 \mathrm{R}$ & 540 & 31 & 8,00 & $120<\mathrm{T}<140$ & 2,1 \\
\hline
\end{tabular}

O corpo de prova 3 foi soldado em corrente contínua de polaridade reversa (CCPR+), sendo soldado com um passe no chanfro inferior e cinco passes no chanfro superior (quatro camadas), conforme indica a figura 3.3. Os parâmetros de cada passe de soldagem estão indicados na tabela 3.6. 


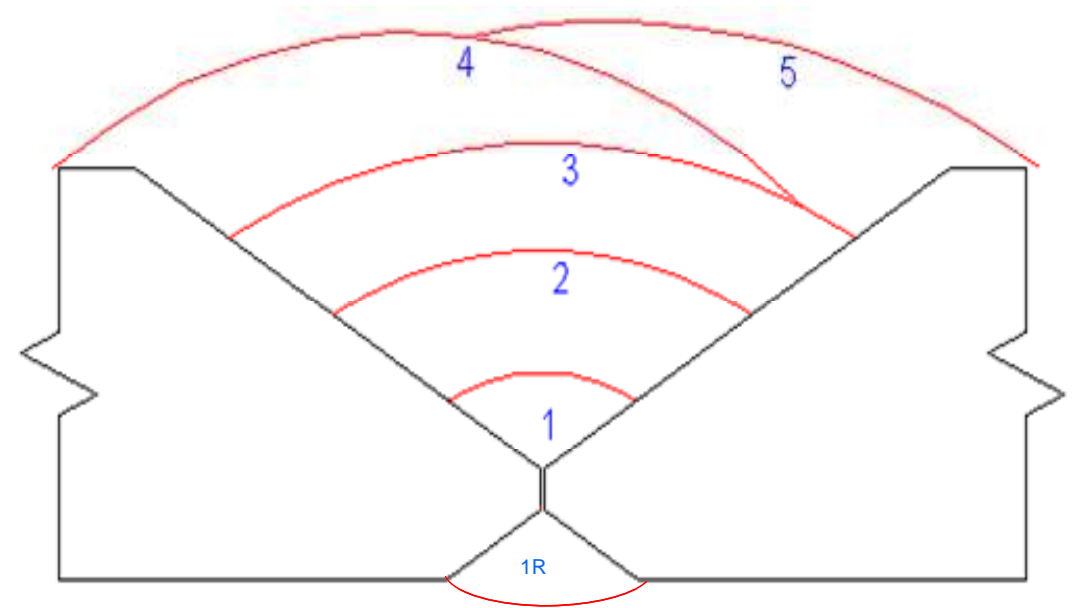

Figura 3.3: Passes de solda no corpo de prova 3.

Tabela 3.6: Parâmetros de soldagem do corpo de prova 3.

\begin{tabular}{|c|c|c|c|c|c|}
\hline Passe & $\begin{array}{c}\text { Corrente de } \\
\text { soldagem } \\
(\mathrm{A})\end{array}$ & $\begin{array}{c}\text { Tensão } \\
\text { do arco } \\
(\mathrm{V})\end{array}$ & $\begin{array}{c}\text { Velocidade } \\
(\mathrm{mm} / \mathrm{s})\end{array}$ & $\begin{array}{c}\text { Temperatura } \\
\text { interpasse } \\
\left({ }^{\circ} \mathrm{C}\right)\end{array}$ & $\begin{array}{c}\text { Energia de } \\
\text { soldagem } \\
(\mathrm{KJ} / \mathrm{mm})\end{array}$ \\
\hline 1 & 440 & 29 & 7,83 & $120<\mathrm{T}<140$ & 1,6 \\
\hline 2 & 540 & 30 & 7,83 & $120<\mathrm{T}<140$ & 2,1 \\
\hline 3 & 540 & 31 & 8,00 & $120<\mathrm{T}<140$ & 2,1 \\
\hline 4 & 540 & 31 & 8,00 & $120<\mathrm{T}<140$ & 2,1 \\
\hline 5 & 540 & 31 & 7,83 & $120<\mathrm{T}<140$ & 2,1 \\
\hline $1 \mathrm{R}$ & 550 & 31 & 8,00 & $120<\mathrm{T}<140$ & 2,1 \\
\hline
\end{tabular}

$\mathrm{Na}$ soldagem do corpo de prova 4 utilizou-se corrente alternada de onda quadrada balanceada com freqüência de onda de $70 \mathrm{~Hz}$. Foram necessários dois passes (duas camadas) no chanfro inferior e cinco passes no chanfro superior (quatro camadas), conforme ilustra a figura 3.4. Os parâmetros de cada passe estão descritos na tabela 3.7 . 


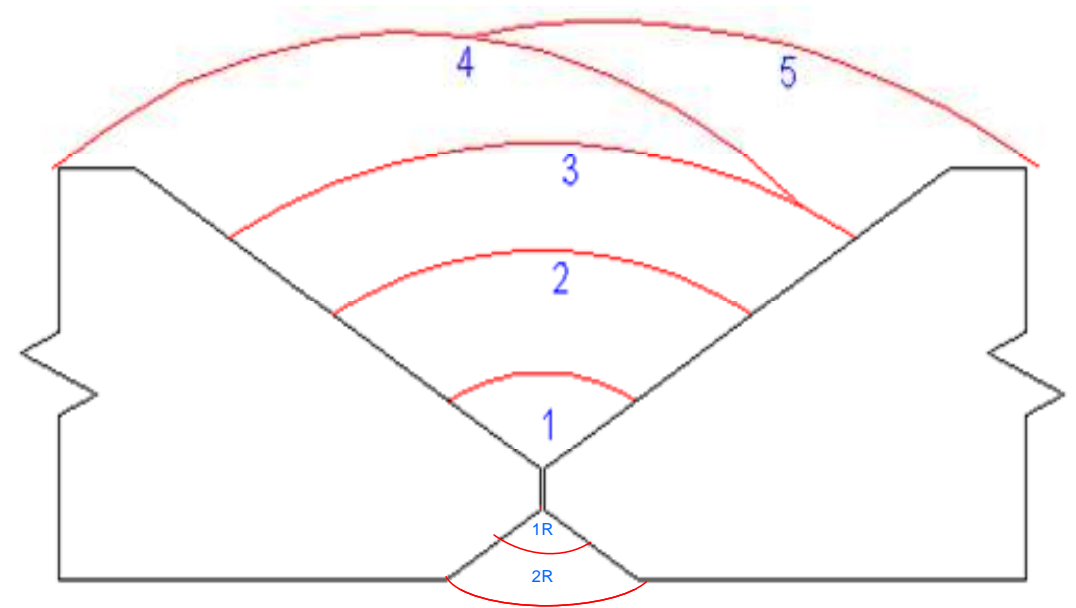

Figura 3.4: Passes de solda no corpo de prova 4.

Tabela 3.7: Parâmetros de soldagem do corpo de prova 4.

\begin{tabular}{|c|c|c|c|c|c|}
\hline Passe & $\begin{array}{c}\text { Corrente de } \\
\text { soldagem } \\
(\mathrm{A})\end{array}$ & $\begin{array}{c}\text { Tensão } \\
\text { do arco } \\
(\mathrm{V})\end{array}$ & $\begin{array}{c}\text { Velocidade } \\
(\mathrm{mm} / \mathrm{s})\end{array}$ & $\begin{array}{c}\text { Temperatura } \\
\text { interpasse } \\
\left({ }^{\circ} \mathrm{C}\right)\end{array}$ & $\begin{array}{c}\text { Energia de } \\
\text { soldagem } \\
(\mathrm{kJ} / \mathrm{mm})\end{array}$ \\
\hline 1 & 400 & 29 & 8,17 & $120<\mathrm{T}<140$ & 1,4 \\
\hline 2 & 480 & 30 & 8,33 & $120<\mathrm{T}<140$ & 1,7 \\
\hline 3 & 515 & 31 & 8,33 & $120<\mathrm{T}<140$ & 1,9 \\
\hline 4 & 535 & 31 & 8,33 & $120<\mathrm{T}<140$ & 2,0 \\
\hline 5 & 535 & 31 & 8,08 & $120<\mathrm{T}<140$ & 2,1 \\
\hline $1 \mathrm{R}$ & 545 & 31 & 8,00 & $120<\mathrm{T}<140$ & 2,1 \\
\hline $2 \mathrm{R}$ & 550 & 32 & 8,00 & $120<\mathrm{T}<140$ & 2,2 \\
\hline
\end{tabular}

A fim de facilitar a identificação das condições de soldagem, será adotada a seguinte nomenclatura:

- $(\mathrm{CA} / \mathrm{N}) \rightarrow$ Corpo de prova 1 , soldado em corrente alternada de onda quadrada balanceada e fluxo neutro;

- $(\mathrm{CC} / \mathrm{N}) \rightarrow$ Corpo de prova 2 , soldado em corrente contínua de polaridade reversa - CCPR (+) - e fluxo neutro; 
- $(\mathrm{CC} / \mathrm{L}) \rightarrow$ Corpo de prova 3, soldado em corrente contínua de polaridade reversa - CCPR (+) - e fluxo ligado;

- $(\mathrm{CA} / \mathrm{L}) \rightarrow$ Corpo de prova 4 , soldado em corrente alternada de onda quadrada balanceada e fluxo ligado.

\subsection{Ensaios realizados na junta soldada}

Para evitar efeitos indesejados como de superfície e instabilidade do arco, todos os ensaios foram realizados a partir de regiões afastadas das extremidades das chapas e de regiões que tiveram ciclos térmicos diferenciados, conforme indicado na figura 3.5.

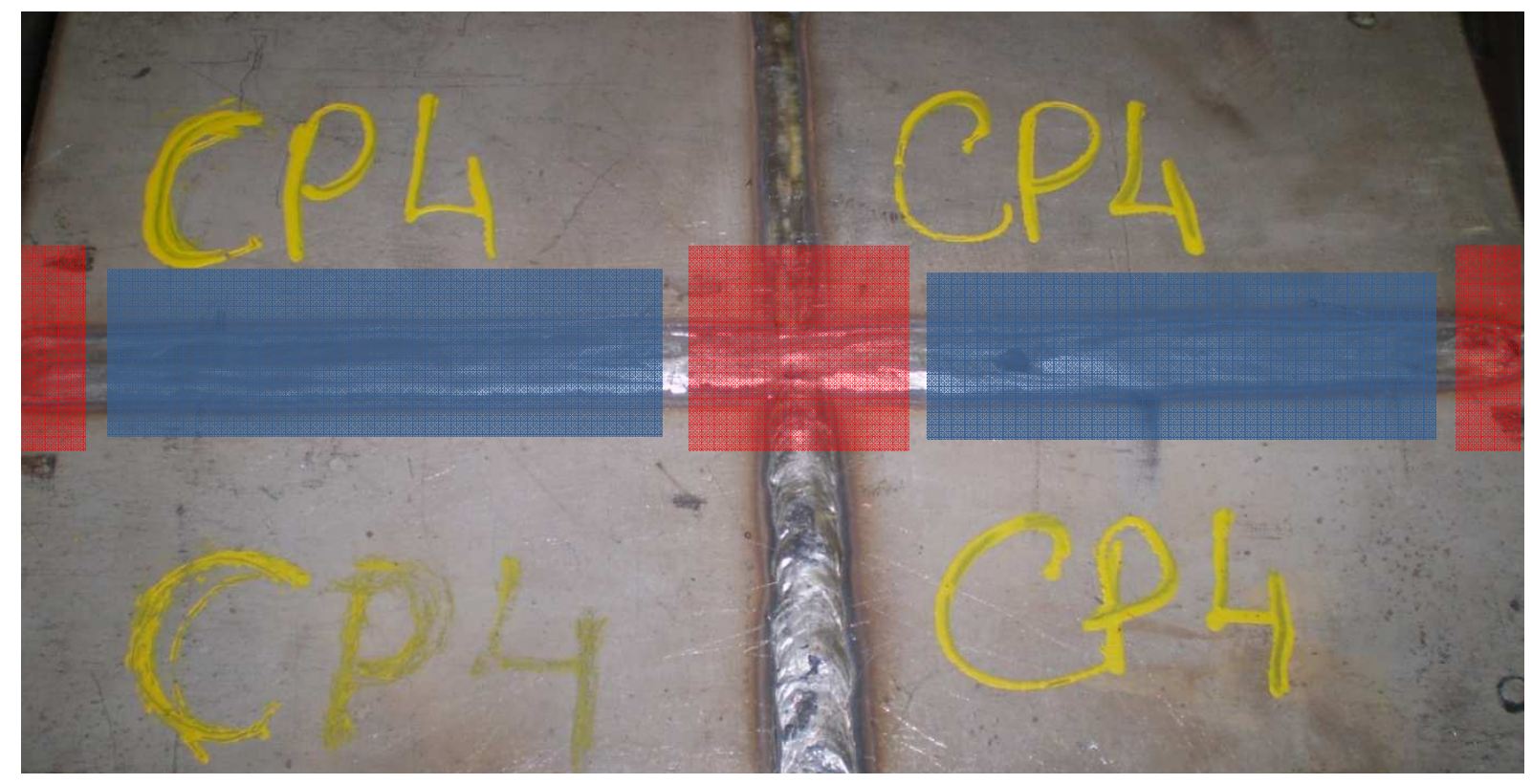

Figura 3.5: Um dos corpos de prova após o processo de soldagem, com representação das regiões desprezadas nos ensaios (em vermelho) devido a efeitos indesejados como de superfície e instabilidade do arco, e representação de exemplo de região utilizada para ensaio (em azul).

\subsubsection{Composição química.}


Todos os materiais empregados tiveram suas análises químicas determinadas através dos seguintes métodos:

Equipamento Leco (oxigênio, carbono e enxofre): Através da combustão de uma amostra em um fluxo de oxigênio puro, os teores de carbono e enxofre são medidos através da formação de $\mathrm{CO}_{2}$ e $\mathrm{SO}_{2}$, respectivamente. $\mathrm{O}$ teor de oxigênio, por sua vez, é obtido através da fusão do oxigênio em um cadinho de grafite na presença de um fluxo de gás inerte, levando à formação de $\mathrm{CO}_{2}$. Foi medido o teor de oxigênio total da amostras. As quantificações dos gases formados nas análises dos três elementos se dão através de espectroscopia no infravermelho. Os demais elementos tiveram seus teores medidos por via úmida.

Em inclusões observadas durante microscopia eletrônica de varredura, utilizou-se espectroscopia de emissão óptica.

A fim de se obter a composição química do metal depositado (arame + fluxo), foram realizados diversos passes de soldagem sobrepostos sobre a superfície de uma chapa, de maneira que nos passes localizados na região superior não há influência do material da chapa em sua composição química (sem diluição).

\subsubsection{Caracterização microestrutural.}

Foram realizadas macrografias das juntas soldadas, que foram fotografadas com câmera digital. Nestas amostras foram feitas medidas das frações volumétricas de ferrita, empregando-se um ferritoscópio marca Fischer, no centro da junta com espaçamentos de $4 \mathrm{~mm}$ entre medidas, conforme a figura 3.6. Nas regiões em que o cordão de solda é mais largo, as medições foram efetuadas em três posições distintas e foi calculada a média aritmética entre elas. 


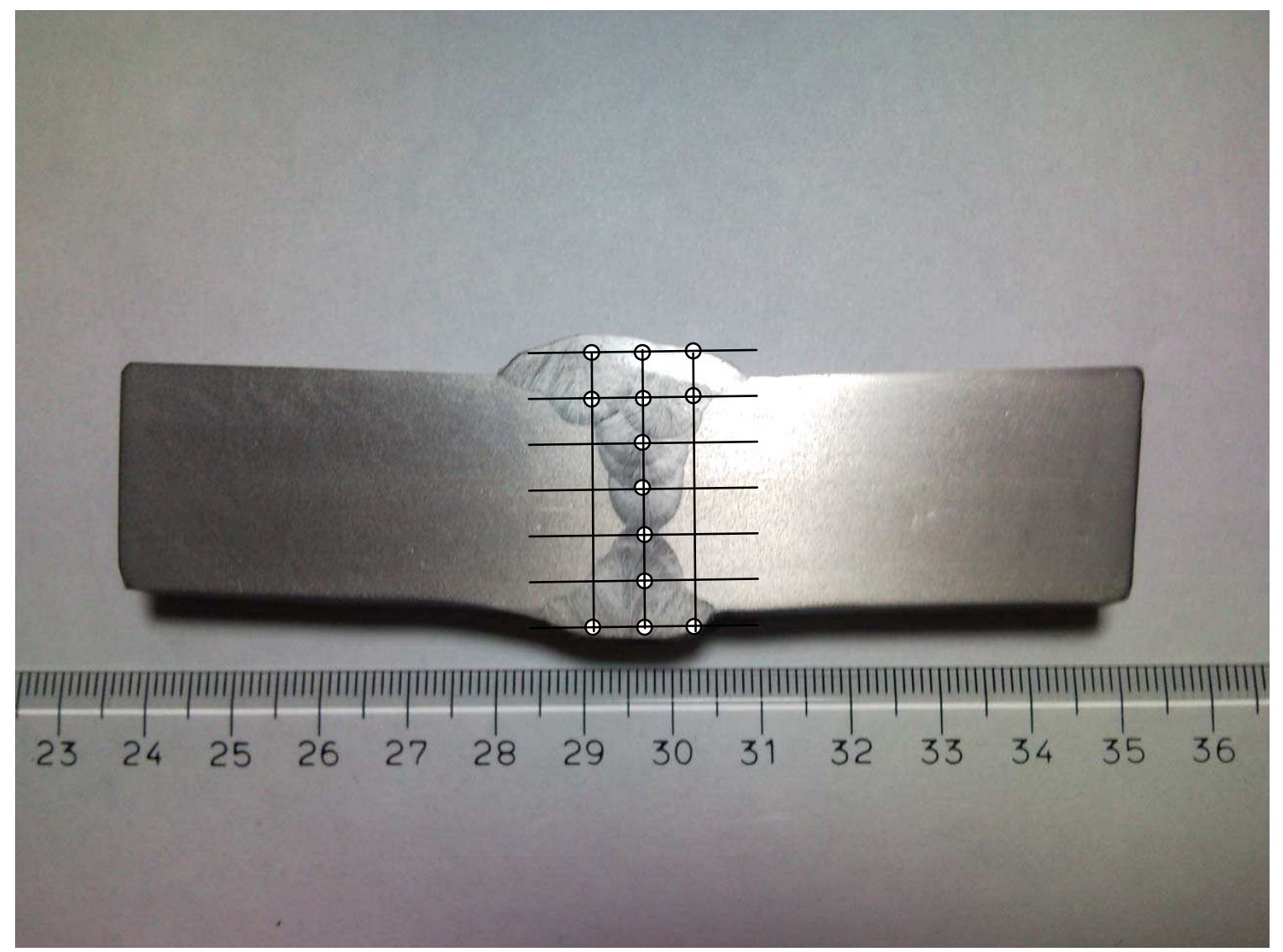

Figura 3.6: Posições em que foram realizadas as medições dos teores de ferrita nos cordões de solda dos quatro corpos de prova.

Todos os quatro corpos de prova foram cortados e embutidos em baquelite, seguido de polimento metalográfico. As amostras foram atacadas com ácido oxálico $10 \%$ com tensão de $6 \mathrm{~V}$ e tempo de 10s. Em seguida, as amostras foram fotografadas em microscópio óptico e microscópio eletrônico de varredura. Quando necessário foram realizadas micro-análises químicas por dispersão de energia. As direções em que foram feitas as microscopias óptica e eletrônica de varredura nos corpos de prova dos ensaios charpy estão representadas na figura 3.7: Microsopia eletrônica de varredura realizada no plano da fratura, enquanto a microscopia óptica foi feita no plano perpendicular à fratura. 

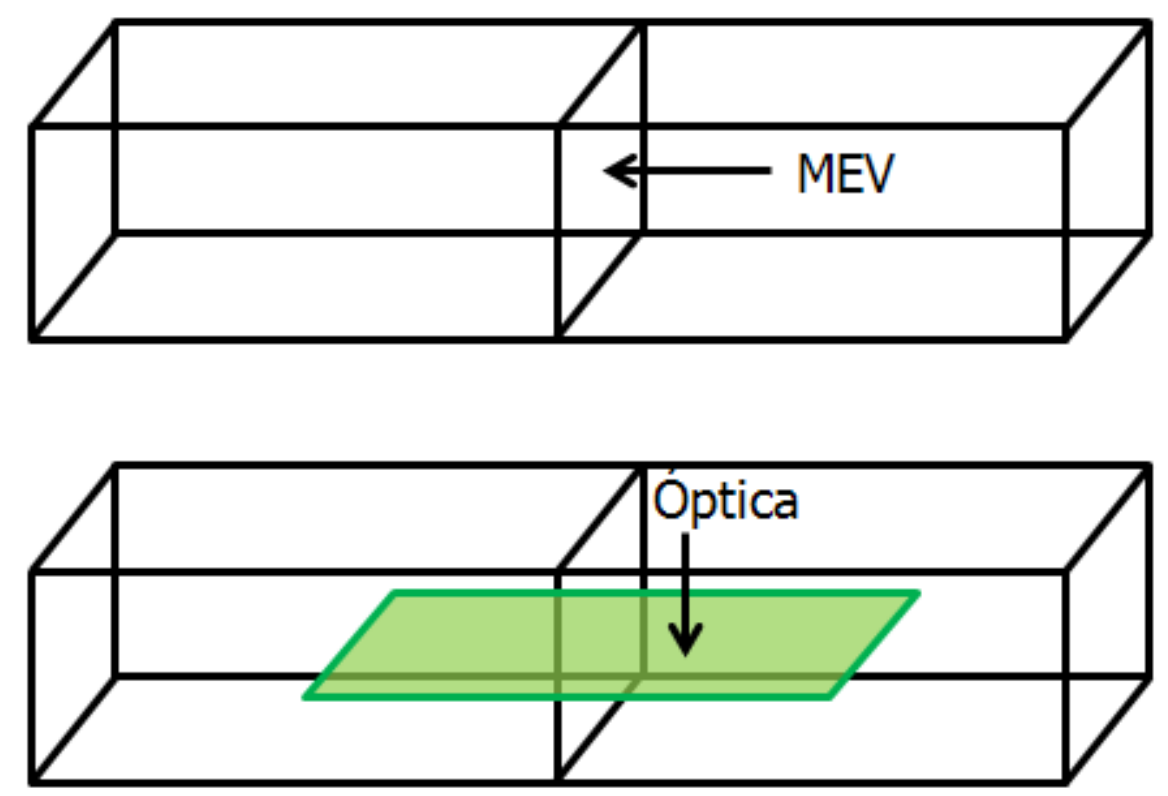

Figura 3.7: Direções observadas nas microscopias óptica e eletrônica de varredura nos corpos de prova charpy.

Os tamanhos médios dos alvéolos foram obtidos nas imagens obtidas nas microscopias eletrônicas de varredura, traçando-se uma reta e posterior contagem do número de alvéolos presentes em determinada distância. O procedimento foi realizado três vezes para cada um dos quatro corpos de prova.

\subsubsection{Diluição}

A diluição foi calculada pela relação entre as áreas do metal de base fundido e a do metal de solda nas macrografias, conforme representado na figura 3.8, através da equação 3.1: 


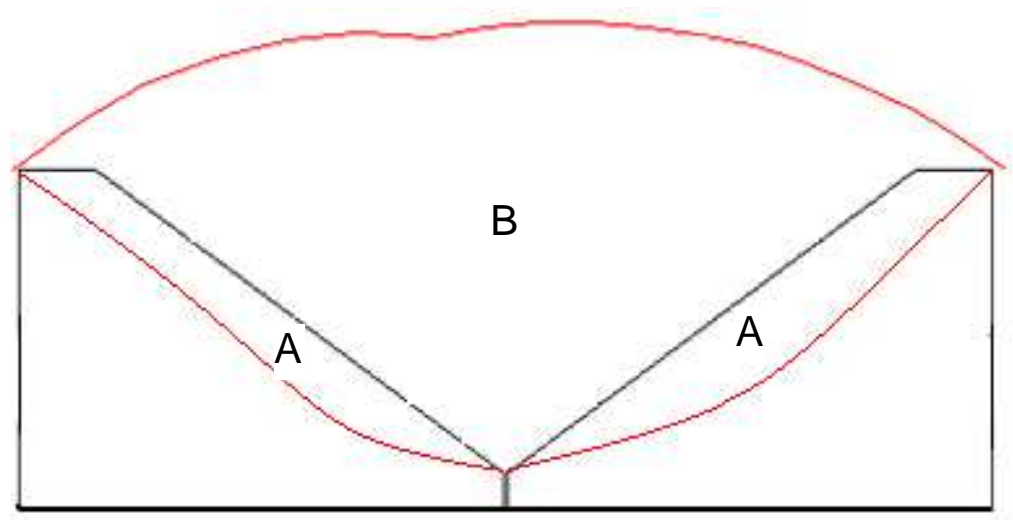

Figura 3.8: Representação do metal de base fundido (A) e do metal de adição (B) no cordão de solda, para cálculo da diluição.

$$
\text { Diluição }=\frac{\mathrm{A}}{\mathrm{A}+\mathrm{B}}
$$

\subsubsection{Propriedades mecânicas.}

Os corpos de prova soldados por cada parâmetro de soldagem foram submetidos a diversos ensaios:

- Tração transversal (temperatura ambiente) = 1 corpo de prova;

- Dobramento lateral (temperatura ambiente) = 2 corpos de prova;

- Impacto Charpy $\mathrm{V}\left(-100^{\circ} \mathrm{C}\right)=5$ corpos de prova.

Os ensaios de tração transversal foram realizados de acordo com o parágrafo QW 152 da norma ASME IX [68], o qual determina que o limite de resistência deve ser calculado com base na carga máxima de carregamento dividida pela área da secção transversal inicial do corpo de prova.

Os ensaios de dobramento lateral foram realizados de acordo com o parágrafo QW 162, figura QW 462.2 da norma ASME IX [68], no qual o corpo de prova é 
submetido a um carregamento que o força para dentro de uma matriz até que o mesmo atinja um ângulo de dobramento, conforme ilustra a figura 3.9.
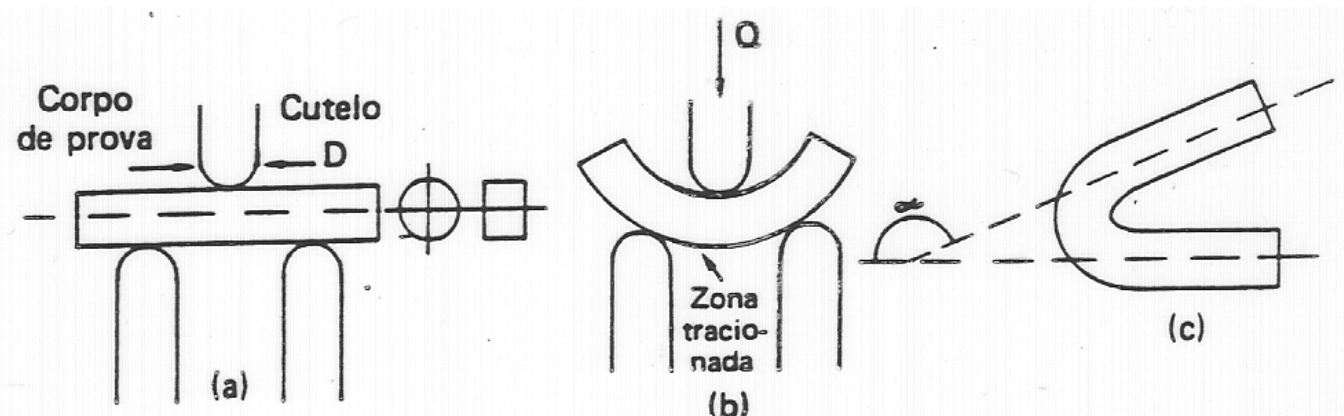

(b)

Figura 3.9: Representação do ensaio de dobramento transversal, no qual o corpo de prova é submetido a uma carga aplicada por um cutelo em sua região central (no caso, a zona fundida) e apoiado sobre dois roletes próximos às extremidades [69].

Os ensaios de impacto Charpy foram realizados de acordo com a norma ASTM E23 a $-100^{\circ} \mathrm{C}$, utilizando-se cinco corpos de prova para a região da face do cordão de solda e para a sua raiz, com entalhe feito por brochadeira. Os corpos de prova foram mantidos a esta temperatura por uma mistura de nitrogênio em álcool puro (99,9\%), com o auxílio de equipamento de refrigeração do banho. Nestes corpos de prova foram medidas também as expansões laterais.

Os corpos de prova fraturados no ensaio de tração e no ensaio Charpy tiveram suas superfícies de fratura observadas no microscópio eletrônico de varredura. As fraturas dos corpos-de-prova do ensaio Charpy forma embutidas e observadas no microscópio óptico, empregando-se o mesmo ataque químico citado anteriormente. As expansões laterais foram obtidas através da diferença entre a largura do corpo de prova na região deformada e na região não deformada, conforme a figura 3.10 ( representadas pelas linhas $A$ e $B$, respectivamente). 


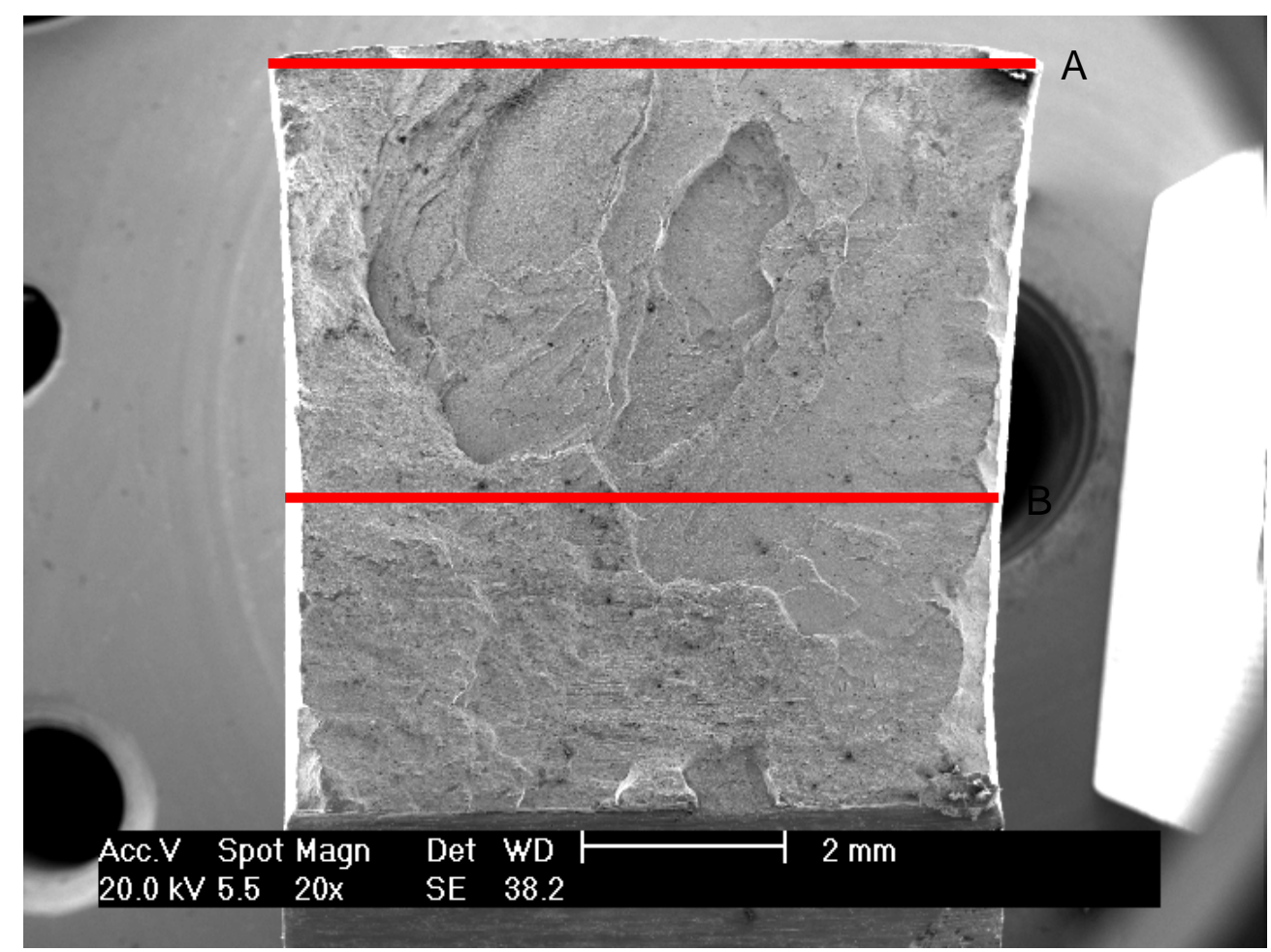

Figura 3.10: Regiões utilizadas nos corpos de prova dos ensaios Charpy para obtenção das expansões laterais: Região deformada (A) e não deformada (B).

\subsection{Análise estatística}

A fim de verificar se os resultados experimentais obtidos podem ser considerados iguais ou diferentes, utilizou-se o método estatístico de comparação de duas médias através da comparação entre $Z$ calculado $\left(Z_{\text {calc }}\right)$ e $Z$ crítico $\left(Z_{\text {crit }}\right)$ [70]. As médias podem ser consideradas iguais caso $Z_{\text {calc }}<Z_{\text {crit }}$ para $o$ nível de significância em questão. $Z_{\text {calc }}$ pode ser obtido através da equação (3.2):

$$
Z_{\text {calc }}=\frac{\mu_{1}-\mu_{2}}{\sqrt{\frac{\sigma_{1}^{2}}{n_{1}}+\frac{\sigma_{2}^{2}}{n_{2}}}}
$$


Onde: $\mu_{\mathrm{i}}$ é a média da amostra, $\sigma_{\mathrm{i}}$ é o desvio padrão da amostra e $n_{i}$ é a quantidade de dados da amostra. Os valores de Z crítico para os níveis de significância de $0,1 \%, 0,5 \%, 1 \%$ e $5 \%$ estão tabelados no anexo A.

Segundo Neto [70], uma vez que os dados não estão emparelhados não há sentido em calcular as diferenças entre os valores das duas amostras (no qual se baseia o teste t). Neste caso, deve-se usar a diferença entre as médias das duas amostras, no que se baseia o teste utilizado. 


\section{Resultados e discussão.}

\subsection{Análise química.}

Os resultados da análise química do material depositado nos quatro corpos de prova (fluxo ligado + arame ER 308L para os corpos de prova 3 e 4, fluxo neutro + arame ER 308L para os corpos de prova 1 e 2) estão na tabela 4.1, e os teores de cromo e níquel estão representados na figura 4.1: 4.

Tabela 4.1: Teores de diversos elementos nos metais depositados dos corpos de prova 1, 2, $3 \mathrm{e}$

\begin{tabular}{|c|c|c|c|c|c|c|c|c|}
\hline $\begin{array}{c}\text { Corpo de } \\
\text { prova }\end{array}$ & $\% \mathrm{C}$ & $\% \mathrm{Si}$ & $\% \mathrm{~S}$ & $\% \mathrm{P}$ & $\% \mathrm{Mn}$ & $\% \mathrm{Ni}$ & $\% \mathrm{Cr}$ & $\% \mathrm{Mo}$ \\
\hline $1(\mathrm{CA} / \mathrm{N})$ & 0,018 & 0,473 & 0,007 & 0,022 & 1,766 & 9,170 & 18,732 & 0,092 \\
\hline $2(\mathrm{CC} / \mathrm{N})$ & 0,019 & 0,586 & 0,002 & 0,014 & 2,072 & 8,612 & 18,191 & 0,094 \\
\hline $3(\mathrm{CC} / \mathrm{L})$ & 0,014 & 0,542 & 0,008 & 0,025 & 1,460 & 9,127 & 18,638 & 0,090 \\
\hline $4(\mathrm{CA} / \mathrm{L})$ & 0,014 & 0,563 & 0,002 & 0,015 & 1,624 & 8,548 & 18,100 & 0,092 \\
\hline $\begin{array}{c}\text { Corpo de } \\
\text { prova }\end{array}$ & $\% \mathrm{~V}$ & $\% \mathrm{Cu}$ & $\% \mathrm{~W}$ & $\% \mathrm{Ti}$ & $\% \mathrm{Sn}$ & $\% \mathrm{Al}$ & $\% \mathrm{Nb}$ & $\% \mathrm{Fe}$ \\
\hline \begin{tabular}{c}
$1(\mathrm{CA} / \mathrm{N})$ \\
\hline $2(\mathrm{CC} / \mathrm{N})$
\end{tabular} & 0,054 & 0,070 & 0,018 & 0,003 & 0,003 & 0,009 & 0,004 & 69,56 \\
\hline $3(\mathrm{CC} / \mathrm{L})$ & 0,050 & 0,073 & 0,018 & 0,003 & 0,003 & 0,014 & 0,004 & 69,93 \\
\hline $4(\mathrm{CA} / \mathrm{L})$ & 0,051 & 0,073 & 0,016 & 0,004 & 0,003 & 0,020 & 0,004 & 70,87 \\
\hline
\end{tabular}




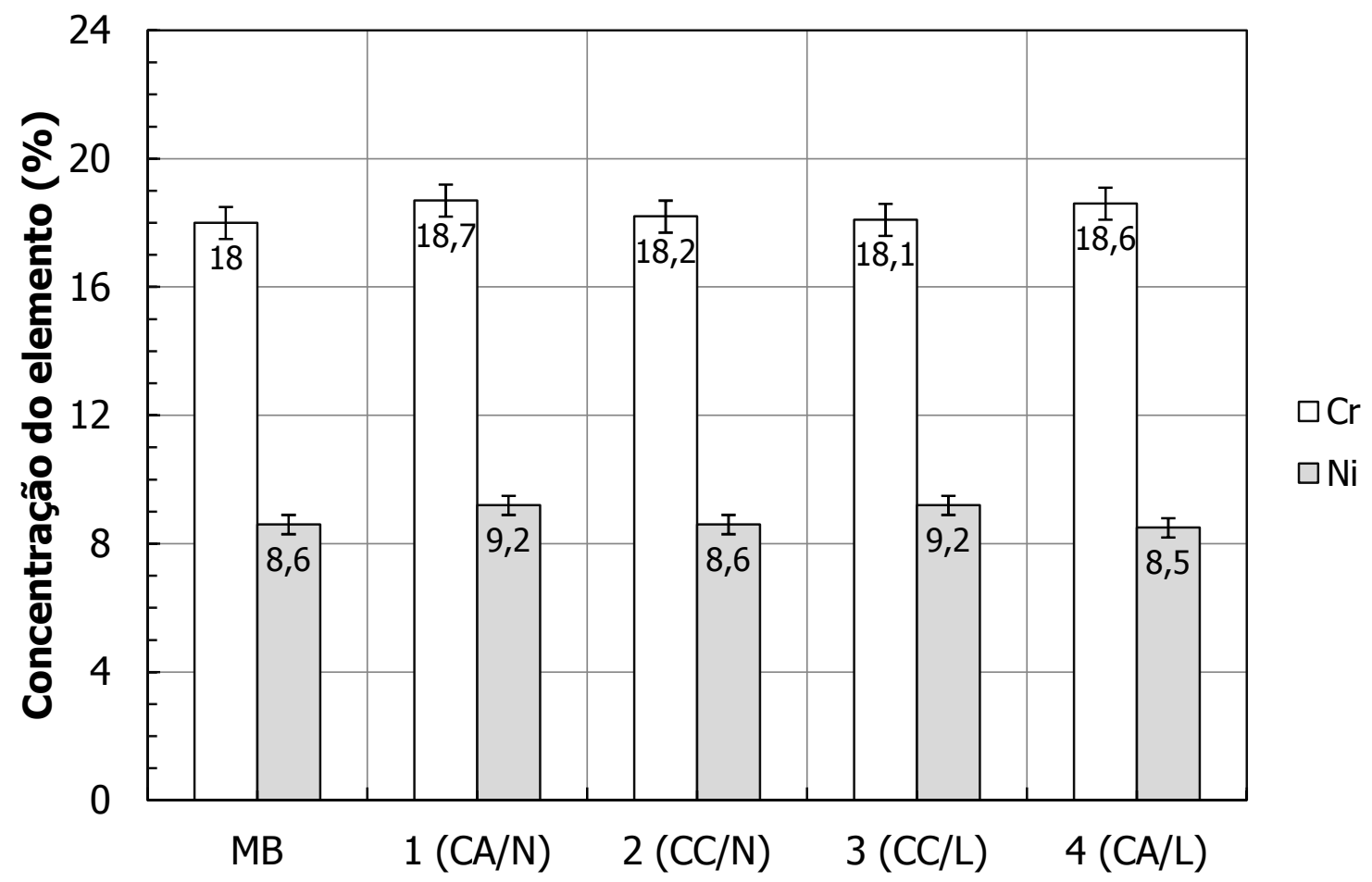

Figura 4.1: Teores de cromo e de níquel no metal de base e nos metais depositados nos corpos de prova 1 a 4.

Através da figura 4.1, nota-se que houve aumento no teor de cromo para todas as condições de soldagem. O maior aumento ocorreu utilizando-se um fluxo neutro e corrente alternada de onda quadrada $(\mathrm{CA} / \mathrm{N})$, e o segundo maior aumento ocorreu para a soldagem com fluxo ligado e corrente alternada de onda quadrada (CA/L). Um aumento significativo no teor de cromo para este corpo de prova (CA/L) era esperado, pois o fluxo ligado utilizado compensa variações no teor de cromo durante a soldagem. Já o aumento significativo utilizando-se fluxo neutro $(C A / N)$ deve ser explicado por outras variáveis, como o tipo de corrente elétrica e diluição.

Como foi utilizada uma corrente elétrica alternada de onda quadrada, a variação na composição química pode ser relacionada à variação na polaridade durante a soldagem por reações eletroquímicas. Quando a poça de fusão é negativa durante soldagem em corrente alternada, ocorre uma reação eletroquímica com o cromo, depositando cromo, níquel e outros metais. Quando a polaridade é alterada para positiva, ocorre uma reação de oxidação do cromo na poça de fusão. As reações opostas ocorrem na ponta do eletrodo. A fim de analisar estas reações, foi 
comparada a variação no teor dos elementos no metal de solda dos diferentes corpos de prova. As tabelas 4.2 a 4.5 apresentam as composições químicas dos metais de solda de face e de raiz, bem como do metal de base, dos corpos de prova 1 a 4.

Tabela 4.2: Concentração de diversos elementos no corpo de prova $1(\mathrm{CA} / \mathrm{N})$.

\begin{tabular}{|c|c|c|c|c|c|c|c|c|}
\hline Região & $\% \mathrm{C}$ & $\% \mathrm{Si}$ & $\% \mathrm{~S}$ & $\% \mathrm{P}$ & $\% \mathrm{Mn}$ & $\% \mathrm{Ni}$ & $\% \mathrm{Cr}$ & $\% \mathrm{Mo}$ \\
\hline $\begin{array}{c}\text { Metal } \\
\text { de base }\end{array}$ & 0,016 & 0,422 & 0,004 & 0,027 & 1,348 & 8,769 & 18,031 & 0,081 \\
\hline Face & 0,023 & 0,480 & 0,006 & 0,021 & 1,841 & 9,344 & 18,912 & 0,092 \\
\hline Raiz & 0,020 & 0,444 & 0,007 & 0,022 & 1,719 & 9,219 & 18,754 & 0,090 \\
\hline Região & $\% \mathrm{~V}$ & $\% \mathrm{Cu}$ & $\% \mathrm{~W}$ & $\% \mathrm{Ti}$ & $\% \mathrm{Sn}$ & $\% \mathrm{Al}$ & $\% \mathrm{Nb}$ & $\% \mathrm{Fe}$ \\
\hline $\begin{array}{c}\text { Metal } \\
\text { de base }\end{array}$ & 0,024 & 0,108 & 0,018 & 0,003 & 0,004 & 0,003 & 0,002 & 71,14 \\
\hline Face & 0,056 & 0,064 & 0,016 & 0,003 & 0,003 & 0,008 & 0,003 & 69,13 \\
\hline Raiz & 0,050 & 0,073 & 0,017 & 0,003 & 0,003 & 0,007 & 0,003 & 69,57 \\
\hline
\end{tabular}

Tabela 4.3: Concentração de diversos elementos no corpo de prova $2(\mathrm{CC} / \mathrm{N})$.

\begin{tabular}{|c|c|c|c|c|c|c|c|c|}
\hline Região & $\% \mathrm{C}$ & $\% \mathrm{Si}$ & $\% \mathrm{~S}$ & $\% \mathrm{P}$ & $\% \mathrm{Mn}$ & $\% \mathrm{Ni}$ & $\% \mathrm{Cr}$ & $\% \mathrm{Mo}$ \\
\hline $\begin{array}{c}\text { Metal } \\
\text { de base }\end{array}$ & 0,015 & 0,423 & 0,005 & 0,029 & 1,349 & 8,799 & 17,948 & 0,082 \\
\hline Face & 0,026 & 0,554 & 0,006 & 0,023 & 2,030 & 9,278 & 18,538 & 0,094 \\
\hline Raiz & 0,019 & 0,491 & 0,006 & 0,027 & 1,660 & 9,012 & 18,183 & 0,087 \\
\hline Região & $\% \mathrm{~V}$ & $\% \mathrm{Cu}$ & $\% \mathrm{~W}$ & $\% \mathrm{Ti}$ & $\% \mathrm{Sn}$ & $\% \mathrm{Al}$ & $\% \mathrm{Nb}$ & $\% \mathrm{Fe}$ \\
\hline $\begin{array}{c}\text { Metal } \\
\text { de base }\end{array}$ & 0,024 & 0,109 & 0,018 & 0,003 & 0,004 & 0,003 & 0,002 & 71,19 \\
\hline Face & 0,055 & 0,068 & 0,015 & 0,004 & 0,003 & 0,012 & 0,003 & 69,29 \\
\hline Raiz & 0,039 & 0,089 & 0,017 & 0,004 & 0,003 & 0,011 & 0,002 & 70,35 \\
\hline
\end{tabular}


Tabela 4.4: Concentração de diversos elementos no corpo de prova 3 (CC/L).

\begin{tabular}{|c|c|c|c|c|c|c|c|c|}
\hline Região & $\% \mathrm{C}$ & $\% \mathrm{Si}$ & $\% \mathrm{~S}$ & $\% \mathrm{P}$ & $\% \mathrm{Mn}$ & $\% \mathrm{Ni}$ & $\% \mathrm{Cr}$ & $\% \mathrm{Mo}$ \\
\hline $\begin{array}{c}\text { Metal } \\
\text { de base }\end{array}$ & 0,027 & 0,497 & 0,000 & 0,014 & 1,469 & 8,458 & 17,600 & 0,086 \\
\hline Face & 0,026 & 0,548 & 0,007 & 0,027 & 1,447 & 9,403 & 18,681 & 0,090 \\
\hline Raiz & 0,029 & 0,493 & 0,006 & 0,027 & 1,422 & 9,185 & 18,526 & 0,088 \\
\hline Região & $\% \mathrm{~V}$ & $\% \mathrm{Cu}$ & $\% \mathrm{~W}$ & $\% \mathrm{Ti}$ & $\% \mathrm{Sn}$ & $\% \mathrm{Al}$ & $\% \mathrm{Nb}$ & $\% \mathrm{Fe}$ \\
\hline $\begin{array}{c}\text { Metal } \\
\text { de base }\end{array}$ & 0,029 & 0,103 & 0,018 & 0,004 & 0,004 & 0,006 & 0,003 & 71,68 \\
\hline Face & 0,048 & 0,078 & 0,017 & 0,003 & 0,004 & 0,014 & 0,003 & 69,61 \\
\hline Raiz & 0,038 & 0,094 & 0,017 & 0,003 & 0,003 & 0,014 & 0,002 & 70,05 \\
\hline
\end{tabular}

Tabela 4.5: Concentração de diversos elementos no corpo de prova 4 (CA/L).

\begin{tabular}{|c|c|c|c|c|c|c|c|c|}
\hline Região & $\% \mathrm{C}$ & $\% \mathrm{Si}$ & $\% \mathrm{~S}$ & $\% \mathrm{P}$ & $\% \mathrm{Mn}$ & $\% \mathrm{Ni}$ & $\% \mathrm{Cr}$ & $\% \mathrm{Mo}$ \\
\hline $\begin{array}{c}\text { Metal } \\
\text { de base }\end{array}$ & 0,012 & 0,463 & 0,001 & 0,018 & 1,421 & 8,399 & 17,637 & 0,083 \\
\hline Face & 0,018 & 0,551 & 0,007 & 0,025 & 1,438 & 9,331 & 18,786 & 0,092 \\
\hline Raiz & 0,019 & 0,462 & 0,006 & 0,022 & 1,522 & 9,251 & 18,842 & 0,090 \\
\hline Região & $\% \mathrm{~V}$ & $\% \mathrm{Cu}$ & $\% \mathrm{~W}$ & $\% \mathrm{Ti}$ & $\% \mathrm{Sn}$ & $\% \mathrm{Al}$ & $\% \mathrm{Nb}$ & $\% \mathrm{Fe}$ \\
\hline $\begin{array}{c}\text { Metal } \\
\text { de base }\end{array}$ & 0,027 & 0,101 & 0,016 & 0,003 & 0,003 & 0,005 & 0,001 & 71,81 \\
\hline Face & 0,052 & 0,071 & 0,017 & 0,003 & 0,003 & 0,013 & 0,003 & 69,59 \\
\hline Raiz & 0,049 & 0,074 & 0,016 & 0,003 & 0,003 & 0,011 & 0,003 & 69,63 \\
\hline
\end{tabular}

Na figura 4.2 estão as variações nas composições químicas no metal de solda em relação ao metal de base para as quatro condições de soldagem efetuadas, obtidas através da comparação entre a concentração dos elementos no metal de base e no metal de solda. Nelas observa-se que houve aumento na concentração dos elementos analisados nos metais de solda. 


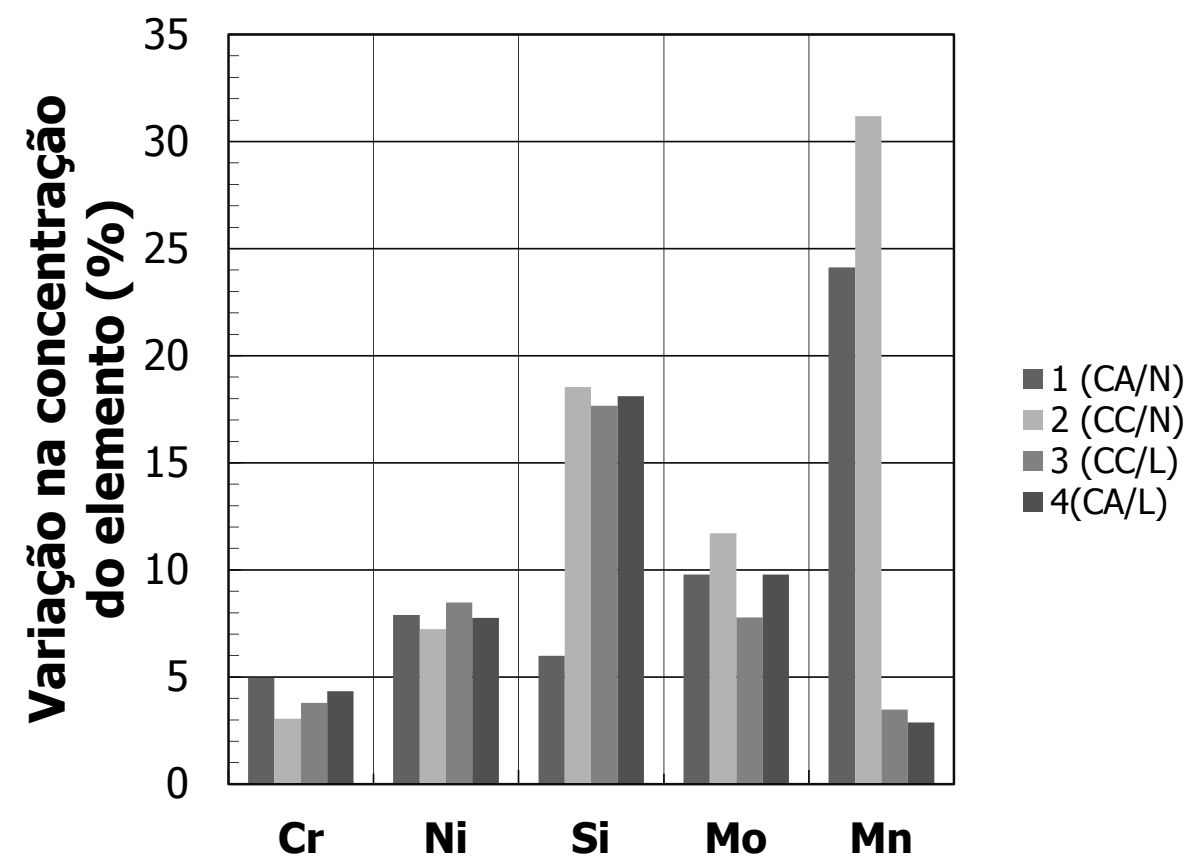

Figura 4.2: Variação nas concentrações de cromo, níquel, silício, molibdênio e manganês no metal de solda para cada parâmetro de soldagem em relação ao metal de base.

Analisando-se a figura 4.2, todas as condições de soldagem levaram a um aumento nos teores de cromo, elemento formador de carboneto, que, desta forma, reduz a tenacidade do aço. O aumento do teor de níquel, que aumenta a resistência mecânica a baixas temperaturas, por favorecer a formação de austenita, em relação ao metal de base. Foi observado um pequeno aumento no teor de molibdênio, que reduz a resistência mecânica a baixas temperaturas por ser um formador de ferrita.

O teor de cromo utilizando-se $(\mathrm{CA} / \mathrm{N})$ apresentou quase o mesmo resultado obtido pela soldagem utilizando-se $(C A / L)$, sendo que ambos apresentaram teor de cromo mais elevado que os corpos de prova soldados em $(\mathrm{CC} / \mathrm{N})$ e $(\mathrm{CC} / \mathrm{L})$. Este aumento no teor de cromo vai de acordo com o observado por Frost et al [49] ao comparar soldagem por arco submerso utilizando-se corrente alternada e corrente contínua. Em seu estudo, porém, foi utilizada corrente alternada de onda senoidal, e não quadrada. Quando a corrente alternada de onda quadrada é utilizada, a tensão do arco e a corrente de soldagem são mantidas quase que constantes com o 
parâmetro da soldagem. Assim, as reações eletroquímicas utilizando-se corrente alternada de onda quadrada são mantidas com uma mesma densidade de carga para cada metade do ciclo.

A diluição também pode afetar a composição química do metal de solda, uma vez que representa a fração de metal de base no metal de solda, que geralmente possui mais impurezas que o metal de base. Assim, quanto maior a diluição, menor o teor de impurezas, levando-se em conta apenas o volume de metal de base fundido e o volume do metal de adição. A figura 4.3 apresenta a diluição dos metais de solda para as condições estudadas.

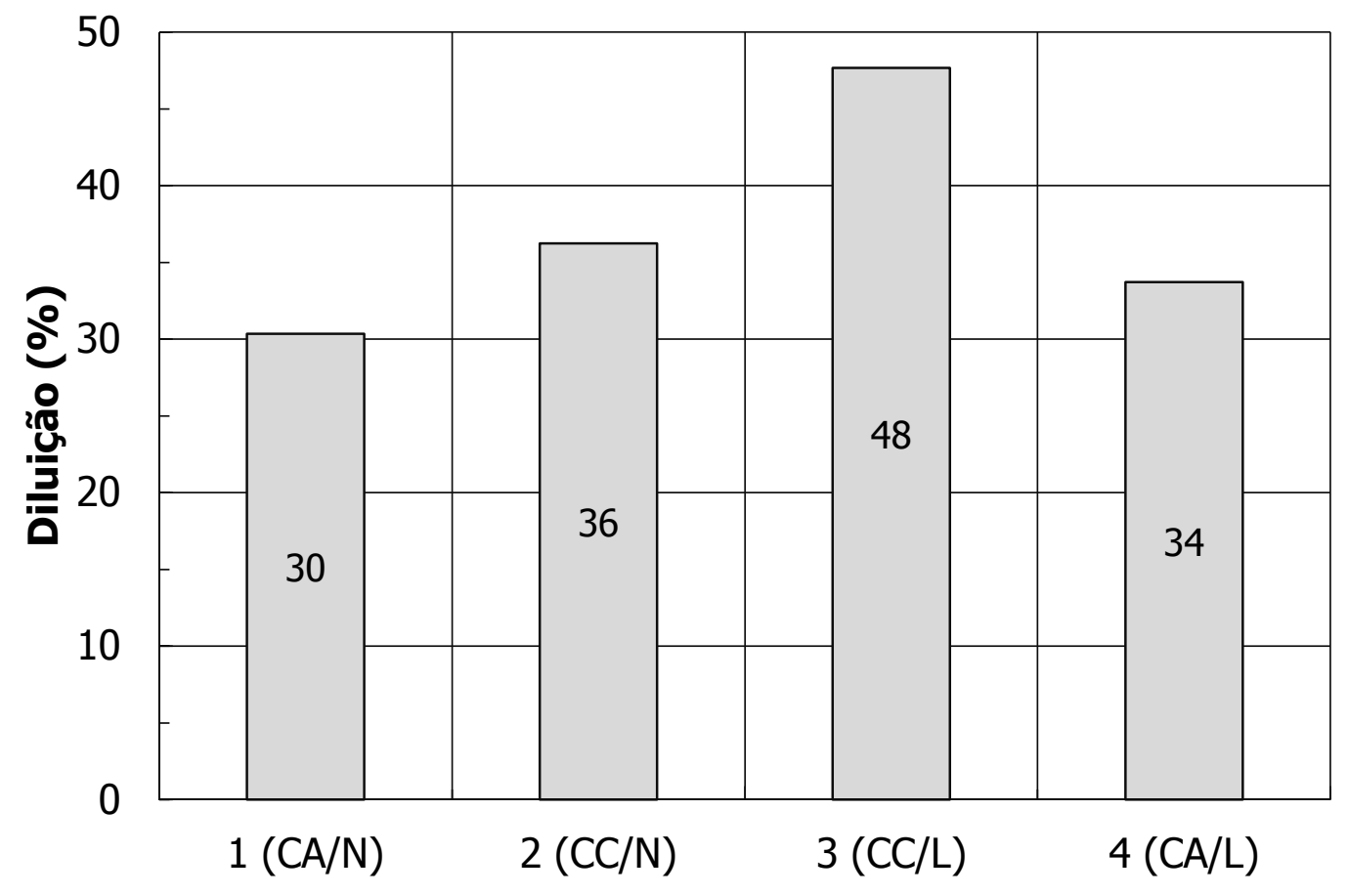

Figura 4.3: Diluição dos cordões de solda para as diferentes condições de soldagem estudadas.

Através da figura 4.3, nota-se que as soldagens realizadas em corrente alternada levaram a menores diluições que as soldagens efetuadas em corrente contínua. Conforme apresentado anteriormente, o processo de soldagem por arco submerso tipicamente apresenta alta penetração em CCPR (+), e alta taxa de deposição em CCPD (-). No caso da soldagem em corrente alternada de onda quadrada 
balanceada, cada um destes efeitos é observado na metade de cada ciclo de corrente, justificando assim as diferenças de diluição observadas.

Observando-se os diferentes tipos de fluxo para um mesmo tipo de corrente, verifica-se que o fluxo neutro apresenta uma menor diluição que o fluxo ligado, o que está relacionado ao teor de oxigênio na poça de fusão.

Em geral, utilizando-se CCPR (+), o aumento no teor de oxigênio aumenta a penetração do cordão de solda, que pode também aumentar a diluição do cordão de solda. No caso de soldagem por corrente alternada, a mudança de polaridade pode alterar o teor de oxigênio devido a reações eletroquímicas durante a soldagem, na poça de fusão. Na tabela 4.6 estão apresentados os teores médios de oxigênio para as quatro condições de soldagem estudadas e do metal de base e, na tabela 4.7, os teores de nitrogênio. Os teores médios de nitrogênio e oxigênio estão representados na figura 4.4. Nela observa-se que as soldagens efetuadas em corrente contínua apresentam teores de oxigênio mais elevados que as soldagens realizadas com corrente alternada.

Tabela 4.6: Teores de oxigênio nos corpos de prova 1 a 4 e do metal de base.

\begin{tabular}{|c|c|c|c|c|}
\hline \multirow{2}{*}{$\begin{array}{c}\text { Corpo de } \\
\text { prova }\end{array}$} & Posição 1 & Posição 2 & Posição 3 & Média \\
\cline { 2 - 5 } & 562 & 283 & 644 & $496 \pm 189$ \\
\hline $1(\mathrm{CA} / \mathrm{N})$ & 457 & 578 & 680 & $572 \pm 112$ \\
\hline $2(\mathrm{CC} / \mathrm{N})$ & 665 & 841 & 883 & $796 \pm 116$ \\
\hline $3(\mathrm{CC} / \mathrm{L})$ & 452 & 410 & 290 & $384 \pm 84$ \\
\hline $4(\mathrm{CA} / \mathrm{L})$ & 82 & 82 & 82 & $82 \pm 0$ \\
\hline Metal de & & & & \\
\hline base & & & & \\
\hline
\end{tabular}


Tabela 4.7: Teores de nitrogênio nos corpos de prova 1 a 4 e do metal de base.

\begin{tabular}{|c|c|c|c|c|}
\hline \multirow{2}{*}{$\begin{array}{c}\text { Corpo de } \\
\text { prova }\end{array}$} & \multicolumn{4}{|c|}{ Teor de nitrogênio (\%) } \\
\cline { 2 - 5 } & Posição 1 & Posição 2 & Posição 3 & Média \\
\hline $1(\mathrm{CA} / \mathrm{N})$ & 0,059 & 0,053 & 0,047 & $0,053 \pm 0,006$ \\
\hline $2(\mathrm{CC} / \mathrm{N})$ & 0,0423 & 0,0447 & 0,0491 & $0,045 \pm 0,003$ \\
\hline $3(\mathrm{CC} / \mathrm{L})$ & 0,0566 & 0,0404 & 0,0485 & $0,049 \pm 0,008$ \\
\hline $4(\mathrm{CA} / \mathrm{L})$ & 0,0498 & 0,0425 & 0,0461 & $0,046 \pm 0,004$ \\
\hline $\begin{array}{c}\text { Metal de } \\
\text { base }\end{array}$ & 0,0339 & 0,0339 & 0,0339 & $0,0339 \pm 0$ \\
\hline
\end{tabular}

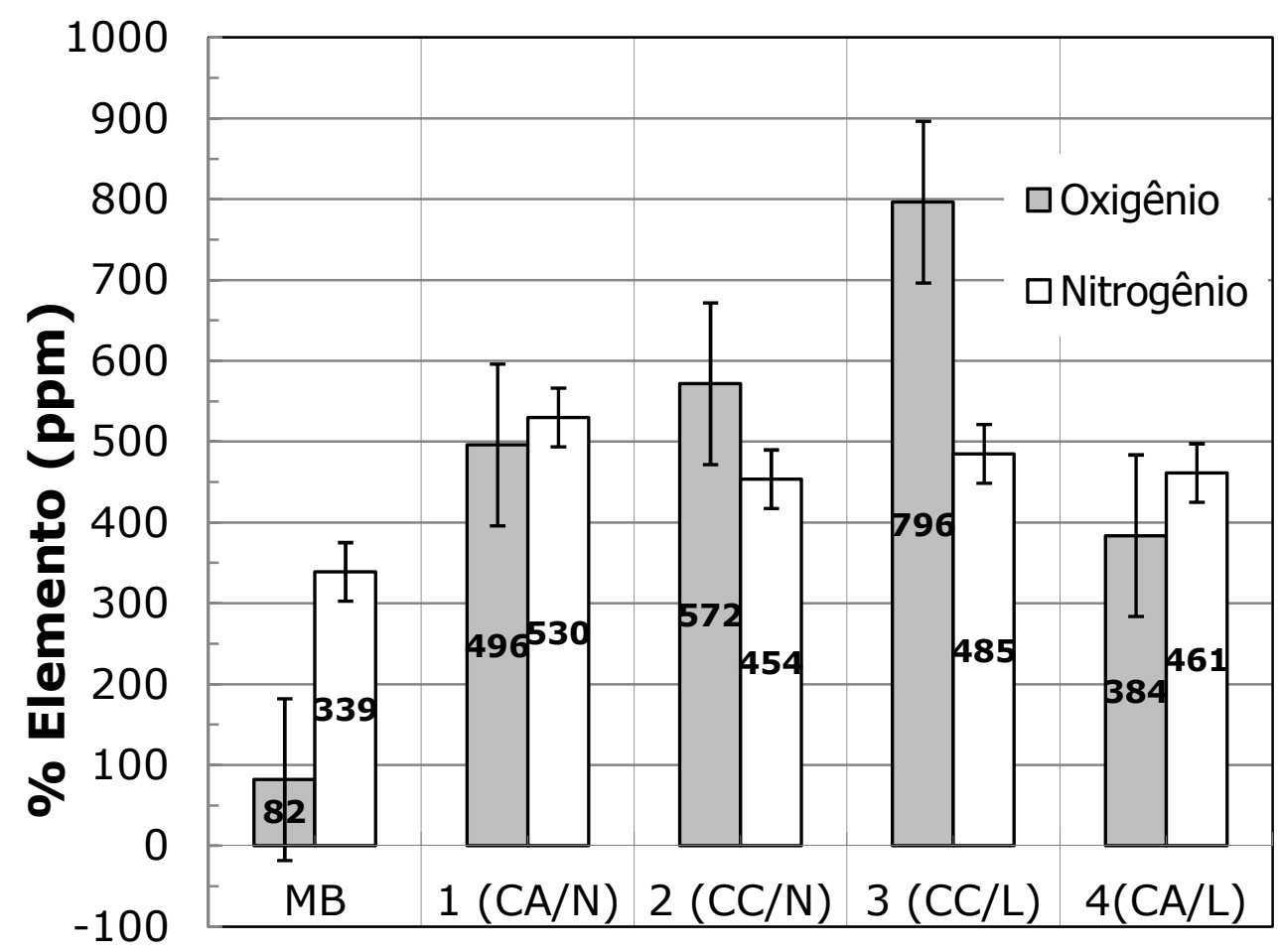

Figura 4.4: Teores médios de nitrogênio e oxigênio no metal de base e na zona fundida dos corpos de prova. 
Ao se comparar os valores da tabela 4.6 e da figura 4.3, verifica-se que o teor de oxigênio para as soldagens em corrente contínua é maior quando o fluxo ligado foi utilizado, seguindo a mesma tendência observada na diluição. A variação na diluição com o teor de oxigênio pode ser causada por um fluxo de Marangoni induzido pelo teor de oxigênio no cordão de solda. No caso de CA, a reação eletroquímica também apresenta uma tendência no teor de oxigênio similar à diluição, ou seja, é menor que o valor obtido na soldagem em CCPR (+). Estes resultados são similares aos resultados obtidos por Frost et al. [49] em aços carbono. O teor de oxigênio no metal de solda também é influenciado pelo índice de basicidade do fluxo, conforme explicado anteriormente. O fluxo neutro utilizado neste trabalho possui um índice de basicidade de 2,70, enquanto o fluxo ligado possui um índice de basicidade de 0,97. Quanto maior o índice de basicidade, menor o teor de oxigênio no cordão de solda (até atingir um teor mínimo para CCPR (+) e aços carbono [38]). Os resultados para aços inoxidáveis seguem a mesma tendência, quando são comparados resultados utilizando-se um mesmo tipo de corrente.

Uma vez que a soldagem em (CC/L) possui uma maior concentração de oxigênio que as demais, isto nos leva a esperar uma menor ductilidade a baixas temperaturas para esta condição de soldagem em relação às demais, conforme os estudos de Lancaster [37] e Hägg [41].

Os teores de carbono, enxofre e fósforo também são importantes para o formato do cordão de solda e propriedades mecânicas a temperaturas baixas ou criogênicas. O teor desses elementos no metal de solda também pode ser controlado por uma reação eletroquímica. No caso de carbono e fósforo, o fluxo neutro apresentou um maior teor destes elementos que o fluxo ligado para a soldagem em CCPR (+). A diluição em $(C C / L)$ deve ser levada em conta na análise destas composições, uma vez que $(C C / L)$ apresentou a maior diluição e, consequentemente, menos impurezas foram introduzidas na poça de fusão. Comparando este resultado com a corrente alternada de onda quadrada, o resultado é oposto principalmente devido à composição química do fluxo, ou seja, o aumento nos teores de carbono e fósforo é maior para o fluxo ligado. Além disso, a diluição para a corrente alternada praticamente não varia, de maneira que o efeito do metal de base fundido influencia de maneira semelhante a composição química desses cordões de solda. A figura 4.5 
apresenta os teores de enxofre, fósforo e carbono para o metal de base e para as quatro condições de soldagem.

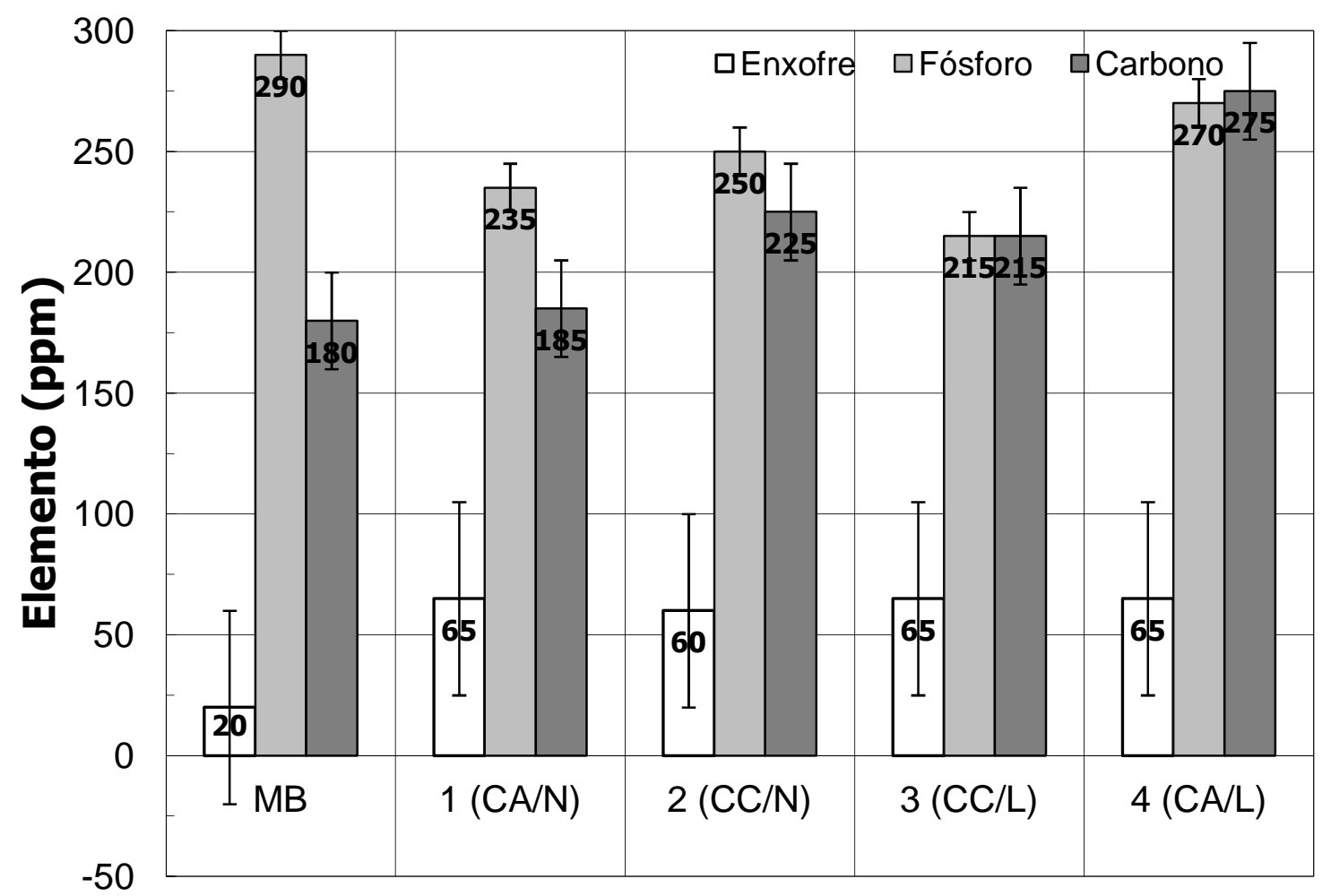

Figura 4.5: Comparação dos teores de enxofre, fósforo e carbono para o metal de base e as quatro condições de soldagem estudadas.

A fim de se analisar o efeito da corrente elétrica na composição química do metal de solda, a variação nos teores de carbono, enxofre, fósforo, oxigênio e nitrogênio foi comparada à composição química do metal de base. Os resultados estão apresentados na figura 4.6. 


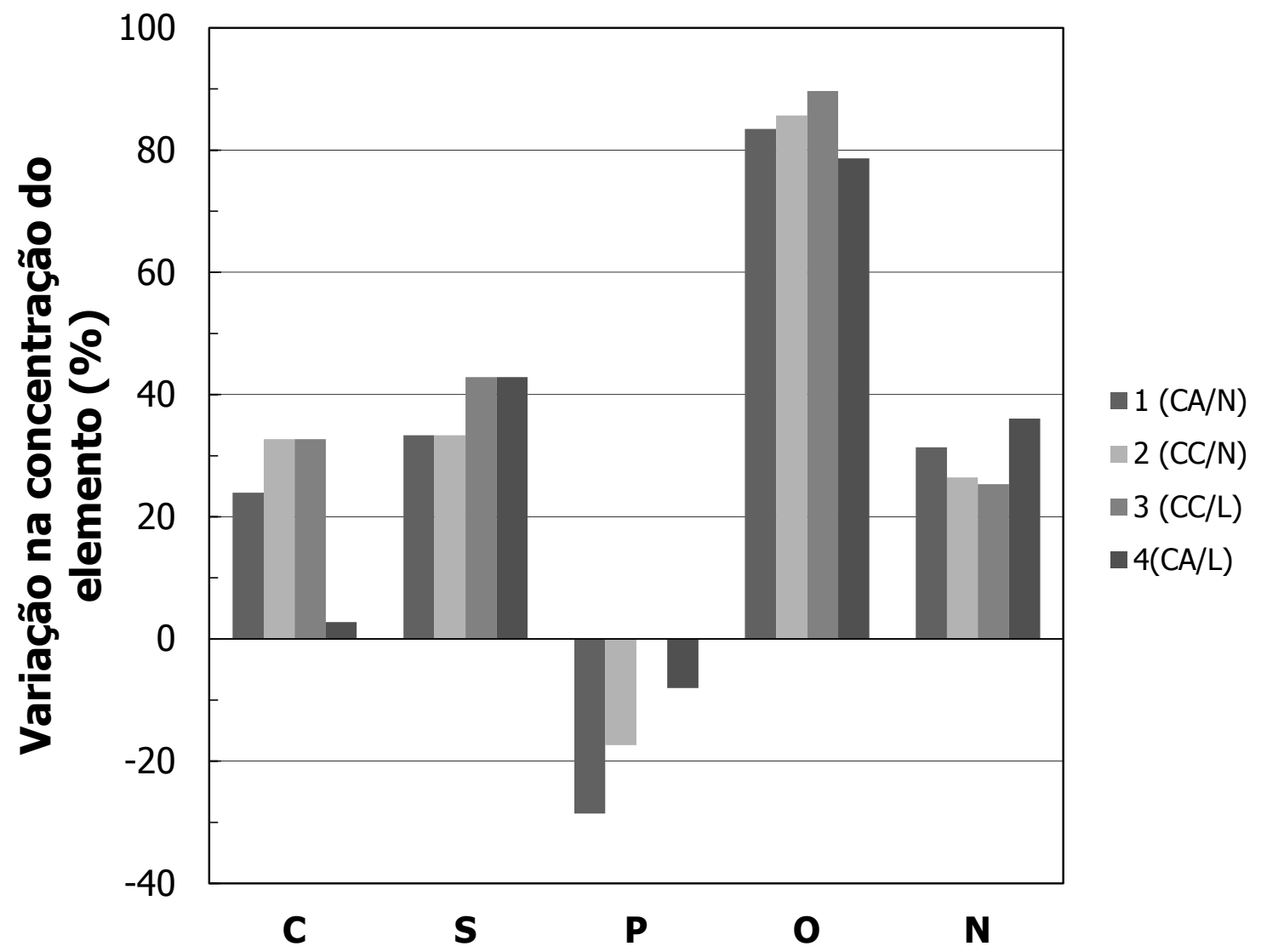

Figura 4.6: Variação nas concentrações de carbono, enxofre, fósforo, oxigênio e nitrogênio no metal de solda para cada parâmetro de soldagem em relação ao metal de base.

Quando o material é soldado em CCPR (+), é observado o mesmo aumento no teor de carbono independentemente do fluxo utilizado. Já quando a soldagem é feita em corrente alternada de onda quadrada, o fluxo neutro produz um aumento maior no teor de oxigênio que o fluxo ligado. Ambas as soldagens efetuadas com corrente contínua levaram a um maior aumento no teor de carbono que as soldagens em corrente alternada. Isto vai de acordo com a tendência de variação de composição química por reação eletroquímica, observada por Indacochea et al [46] em aço carbono.

De acordo com os dados apontados nas tabelas 4.2, 4.3, 4.4 e 4.5, além da figura 4.5, todos os corpos de prova apresentaram teor de carbono abaixo de $0,04 \%$, que é o limite ideal máximo para aplicações sub-zero de aços inoxidáveis austeníticos. Nesta quantidade, o carbono aumenta a resistência da matriz sem 
aumentar significativamente o teor de partículas de segunda fase. Observa-se, porém, que os corpos de prova 1, 2 e 4 apresentaram teores próximos de carbono, no entanto o corpo de prova 3 apresentou em seu metal de base uma concentração significativamente maior que os demais (permanecendo, no entanto, abaixo de $0,04 \%)$.

Em relação à variação do teor de enxofre, observaram-se alterações apenas quando o tipo de fluxo é alterado. Neste caso, o aumento de enxofre no metal de solda pode ocorrer devido à alteração no índice de basicidade, que está relacionado à reação de dessulfurização na poça de fusão a qual é favorecida por uma escória básica produzida por um fluxo básico.

No caso do fósforo, para todas as condições de soldagem houve redução em seu teor em relação ao metal de base. Para o mesmo tipo de corrente, o fluxo neutro, que é básico, levou a maiores reduções de fósforo que o fluxo ligado. Neste caso, a reação de desfosforização é favorecida por um fluxo com alto índice de basicidade, além da reação eletroquímica favorecer a redução no teor de fósforo [46].

A variação do teor de oxigênio também é influenciada pelo índice de basicidade do fluxo e reações eletroquímicas, conforme discutido anteriormente.

Analisando-se a tabela 4.2, nota-se que existe uma diferença de composição química entre o metal de base e o cordão de solda. Comparando-se os cordões de face e de raiz, nota-se que, em geral, o cordão de face apresenta concentração de elementos de liga ligeiramente superior ao cordão de raiz. Este fato pode estar relacionado à maior diluição do passe de raiz, uma vez que os valores da tensão do arco durante a soldagem foram mantidos iguais para todos os cordões de solda realizados nos quatro corpos de prova soldados. Este resultado também é observado nos corpos de prova 2 a 4, cujos resultados estão apresentados nas tabelas 4.3 a 4.5 .

A partir dos resultados das análises químicas apresentados nas tabelas 4.1 a 4.5, obtiveram-se através do cálculo usual os teores de $\mathrm{Ni}_{\text {eq }}$ e $\mathrm{Cr}_{\text {eq }}$ do metal de base, da zona fundida e do metal de adição (arame). Através do cálculo proposto por Hammar e Svenson [37, 62],foram calculados apenas os teores de $\mathrm{Ni}_{\text {eq }}$ e $\mathrm{Cr}_{\text {eq }}$ do 
metal de solda (uma vez que este cálculo foi proposto tendo em vista a solidificação), conforme apresenta a tabela 4.8. O cálculo proposto por Hull [62] não foi utilizado, por ser indicado quando o teor de manganês está entre 5 e 8\%, que não é o caso de nenhum dos corpos de prova estudados.

Tabela 4.8: Teores de Nieq e Creq para os corpos de prova 1, 2, 3 e 4 através do cálculo usual do metal de base, da zona fundida e do metal de adição (arame); e através do cálculo proposto por Hammar e Svenson apenas da zona fundida.

\begin{tabular}{|c|c|c|c|c|c|}
\hline Corpo de prova & Região & $\mathrm{Ni}_{\text {eq }}$ & $\mathrm{Cr}_{\text {eq }}$ & $\mathrm{Ni}_{\text {eq }}(\mathrm{H}-\mathrm{S})$ & $\mathrm{Cr}_{\text {eq }}(\mathrm{H}-\mathrm{S})$ \\
\hline \multirow{3}{*}{$1(\mathrm{CA} / \mathrm{N})$} & Metal de adição & 11,090 & 20,200 & - & - \\
\cline { 2 - 6 } & Metal de base & 9,585 & 18,960 & - & - \\
\cline { 2 - 6 } & Face & 10,534 & 19,726 & 11,186 & 19,773 \\
\cline { 2 - 6 } & Raiz & 10,319 & 19,512 & 10,966 & 19,558 \\
\hline \multirow{3}{*}{$2(\mathrm{CC} / \mathrm{N})$} & Metal de adição & 11,090 & 20,200 & - & - \\
\cline { 2 - 6 } & Metal de base & 9,585 & 18,960 & - & - \\
\cline { 2 - 6 } & Face & 10,558 & 19,465 & 11,202 & 19,516 \\
\cline { 2 - 6 } & Raiz & 10,082 & 19,008 & 10,689 & 19,055 \\
\hline \multirow{3}{*}{$3(\mathrm{CC} / \mathrm{L})$} & Metal de adição & 11,090 & 20,200 & - & - \\
\cline { 2 - 6 } & Metal de base & 9,585 & 18,960 & - & - \\
\cline { 2 - 6 } & Face & 10,683 & 19,595 & 11,146 & 19,641 \\
\cline { 2 - 6 } & Raiz & 10,555 & 19,355 & 11,002 & 19,399 \\
\hline \multirow{3}{*}{$4(\mathrm{CA} / \mathrm{L})$} & Metal de adição & 11,090 & 20,200 & - & - \\
\cline { 2 - 6 } & Metal de base & 9,585 & 18,960 & - & - \\
\cline { 2 - 6 } & Face & 10,371 & 19,706 & 10,996 & 19,754 \\
\cline { 2 - 6 } & Raiz & 10,321 & 19,627 & 10,967 & 19,673 \\
\hline
\end{tabular}

Os resultados obtidos para os teores de $\mathrm{Ni}_{\text {eq }}$ e $\mathrm{Cr}_{\text {eq }}$ para os corpos de prova de 1 a 4 não apresentaram divergências significativas entre si. Pode-se observar que o teor de $\mathrm{Ni}_{\text {eq }}$ obtido através do cálculo proposto por Hammar e Svenson [37, 62] é ligeiramente superior ao obtido através do cálculo usual, enquanto o teor $\mathrm{Cr}_{\mathrm{eq}}$ apresentou uma variação muito pequena alterando-se o cálculo utilizado.

A partir dos teores dos elementos químicos da tabela 4.8, calcularam-se os valores de níquel e cromo equivalente, bem como a relação $\mathrm{Cr}_{\text {eq }} / \mathrm{Ni}_{\text {eq }}$ para os metais depositados, conforme apresenta a tabela 4.9. 
a 4.

Tabela 4.9: Valores de $\mathrm{Cr}_{\text {eq }}, \mathrm{Ni}_{\text {eq }}$ e $\mathrm{Cr}_{\text {eq }} / \mathrm{Ni}_{\text {eq }}$ para os metais depositados nos corpos de prova de 1

\begin{tabular}{|c|c|c|c|c|}
\hline \multicolumn{2}{|c|}{ Corpo de prova } & $\mathrm{Cr}_{\text {eq }}$ & $\mathrm{Ni}_{\text {eq }}$ & $\mathrm{Cr}_{\text {eq }} / \mathrm{Ni}_{\text {eq }}$ \\
\hline \multicolumn{2}{|c|}{ Metal de adição } & 20,200 & 11,090 & 1,821 \\
\hline \multicolumn{2}{|c|}{ Metal de base } & 18,960 & 9,585 & 1,978 \\
\hline \multirow{4}{*}{ 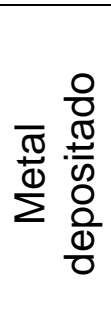 } & $1(\mathrm{CA} / \mathrm{N})$ & 19,536 & 10,593 & 1,844 \\
\hline & $2(\mathrm{CC} / \mathrm{N})$ & 19,167 & 10,218 & 1,876 \\
\hline & $3(\mathrm{CC} / \mathrm{L})$ & 19,543 & 10,277 & 1,902 \\
\hline & $4(\mathrm{CA} / \mathrm{L})$ & 19,039 & 9,780 & 1,947 \\
\hline
\end{tabular}

Pelos valores encontrados acima, nota-se que os fluxos ligados apresentam relação $\mathrm{Cr}_{\text {eq }} / \mathrm{Ni}_{\text {eq }}$ mais elevada que os fluxos neutros, conforme esperado por serem auto-compensantes em cromo. Para os valores obtidos, espera-se um modo de solidificação ferrítico-austenítico (quando $\mathrm{Cr}_{\text {eq }} / \mathrm{Ni}_{\text {eq }}<1,95$ ) ou ferrítico (para $\mathrm{Cr}_{\text {eq }} / \mathrm{Ni}_{\text {eq }}$ $>$ 1,95). A partir destas informações, espera-se a predominância de ferrita acicular no metal de adição.

\subsection{Caracterização metalográfica}

\subsubsection{Macrografias dos cordões de solda}

As macrografias, atacadas com água régia, estão apresentadas na figura 4.7, em que é possível se observar os diversos passes de soldagem realizados em cada corpo de prova (previamente esquematizados nas figuras 3.1 a 3.4). 


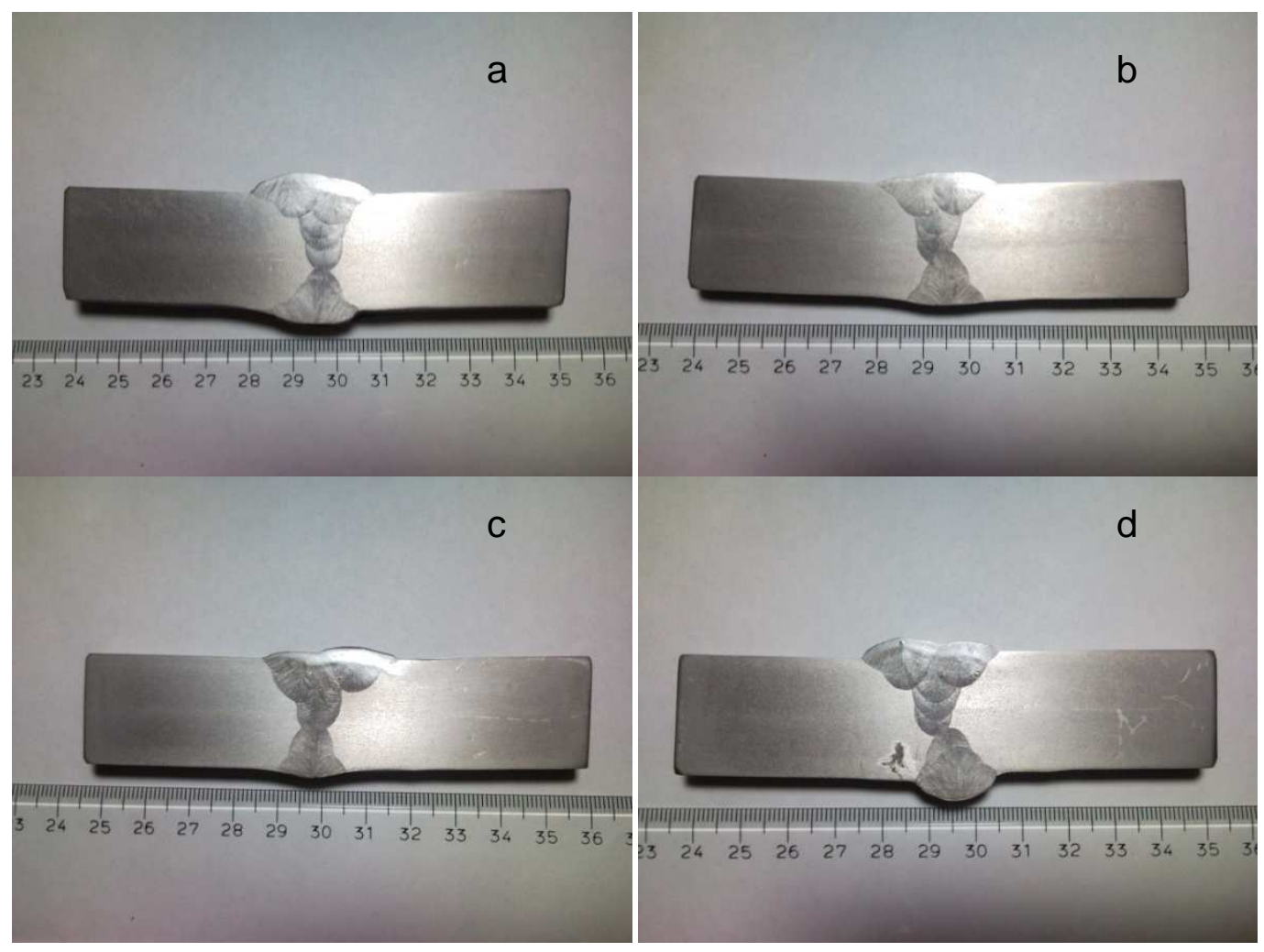

Figura 4.7: Macrografias dos corpos de prova 1 (a), 2 (b), 3 (c) e 4 (d).

\subsubsection{Medida da fração volumétrica de ferrita delta}

As frações volumétricas de ferrita delta nas juntas dos corpos de prova de 1 a 4 foram medidas em um arranjo de pontos de $4 \mathrm{~mm} \times 4 \mathrm{~mm}$, conforme mostra a figura 4.8. Os resultados obtidos estão apresentados na tabela 22. 


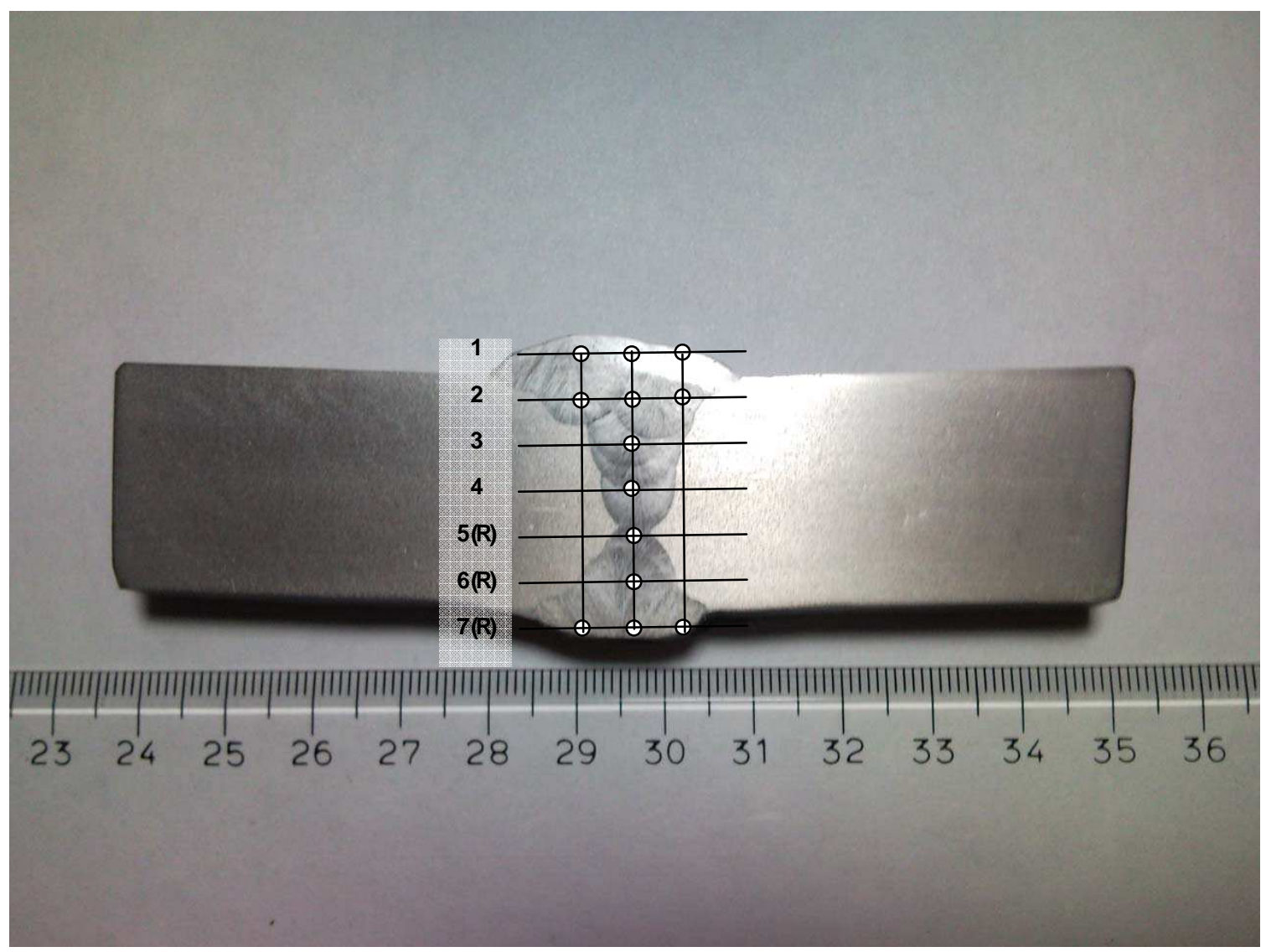

Figura 4.8: Pontos de medição das frações volumétricas de ferrita.

Tabela 4.10: Fração volumétrica de ferrita nas juntas dos corpos de prova 1, 2, 3 e 4.

\begin{tabular}{|c|c|c|c|c|}
\hline CP & $1(\mathrm{CA} / \mathrm{N})$ & $2(\mathrm{CC} / \mathrm{N})$ & $3(\mathrm{CC} / \mathrm{L})$ & $4(\mathrm{CA} / \mathrm{L})$ \\
\hline Camada & \multicolumn{3}{|c|}{ Fração volumétrica de ferrita delta (\%) } \\
\hline 1 & 9,5 & 9,9 & 11,0 & 11,1 \\
\hline 2 & 8,4 & 8,6 & 10,8 & 10,4 \\
\hline 3 & 7,8 & 8,6 & 8,7 & 8,8 \\
\hline 4 & 7,1 & 8,1 & 7,7 & 8,7 \\
\hline 5 (Raiz) & 6,1 & 8,4 & 9,0 & 7,1 \\
\hline 6 (Raiz) & 8,1 & 10,7 & 10,7 & 8,4 \\
\hline 7 (Raiz) & 10,5 & 10,7 & 11,3 & 11,6 \\
\hline
\end{tabular}

A partir dos dados apresentados acima, nota-se que o teor de ferrita delta é maior nos passes de soldagem mais próximos à superfície, ou seja, que contêm menor mistura com o metal de base, tanto para os passes de face quanto de raiz. Isto provavelmente se deve à redução da diluição conforme o passe de soldagem é 
feito sobre outro cordão de solda, que vai de acordo com o resultado apresentado na tabela 4.9 de altos valores para $\mathrm{Cr}_{\text {eq }} / \mathrm{Ni}_{\text {eq }}$ nos metais de adição, levando a um modo de solidificação ferrítico ou ferrítico-austenítico e, consequentemente, maiores teores de ferrita nos metais de adição.

Com base nos resultados apresentados na tabela 4.9, foram construídas as figuras 4.9 e 4.10 , que comparam, para os cordões de solda de cada condição de soldagem, a quantidade de ferrita em diferentes regiões e a quantidade média de ferrita, respectivamente. A partir da observação da tabela 4.10 e da figura 4.9, conclui-se que o corpo de prova $1(\mathrm{CA} / \mathrm{N})$ apresentou uma menor fração volumétrica de ferrita que os demais, com variação aleatória entre os corpos de prova 2, 3 e 4 em relação a qual apresentou o maior teor para cada posição. Já em relação aos teores médios de ferrita (figura 4.10), observa-se que o corpo de prova $3(\mathrm{CA} / \mathrm{L}$ ) apresentou um teor de ferrita mais elevado que os demais, seguido por 4 (CA/L), 2 $(\mathrm{CC} / \mathrm{N})$ e $1(\mathrm{CA} / \mathrm{N})$. 

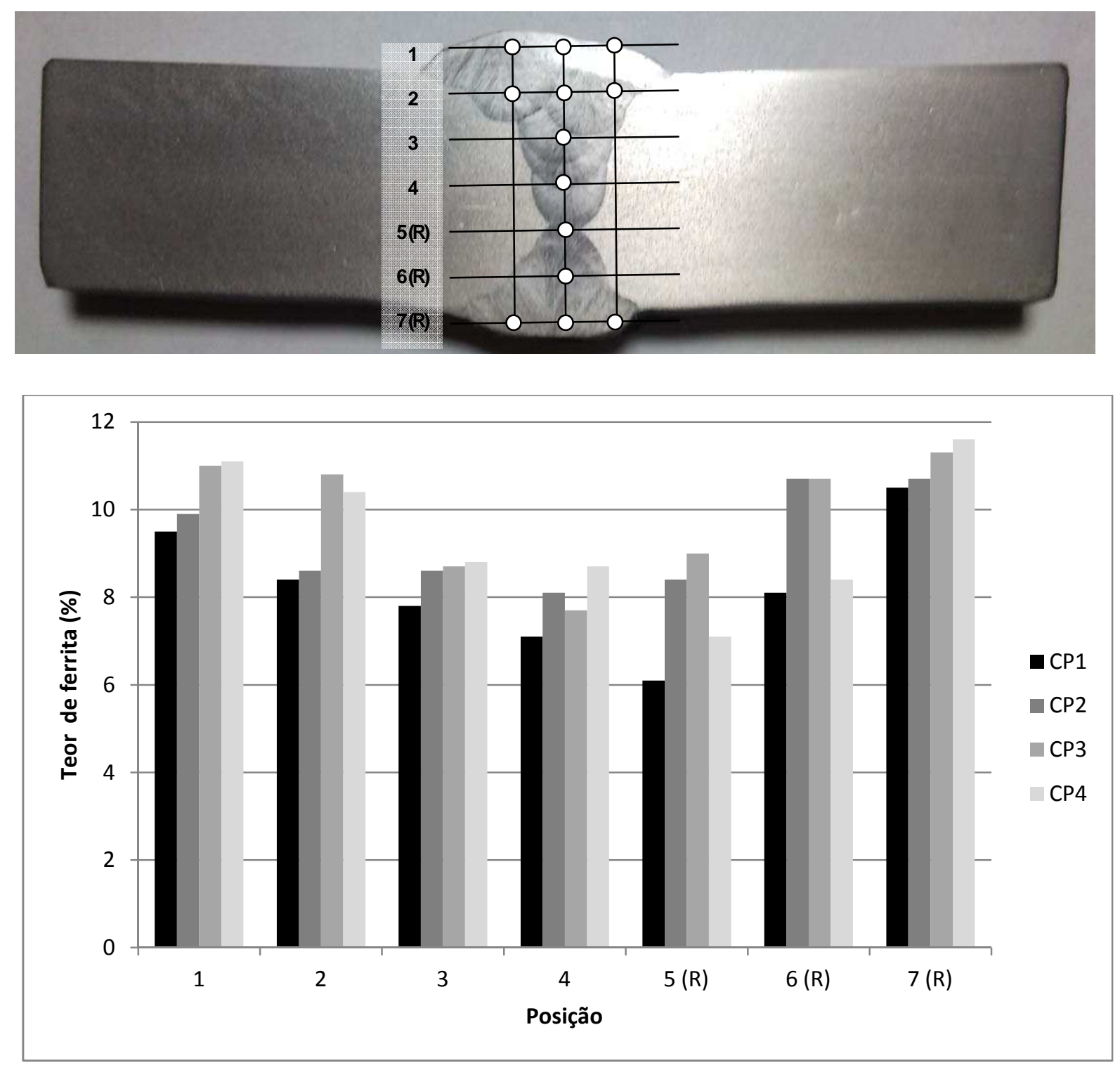

Figura 4.9: Comparação da fração volumétrica de ferrita em diversas regiões das juntas soldadas dos corpos de prova de 1 a 4. 


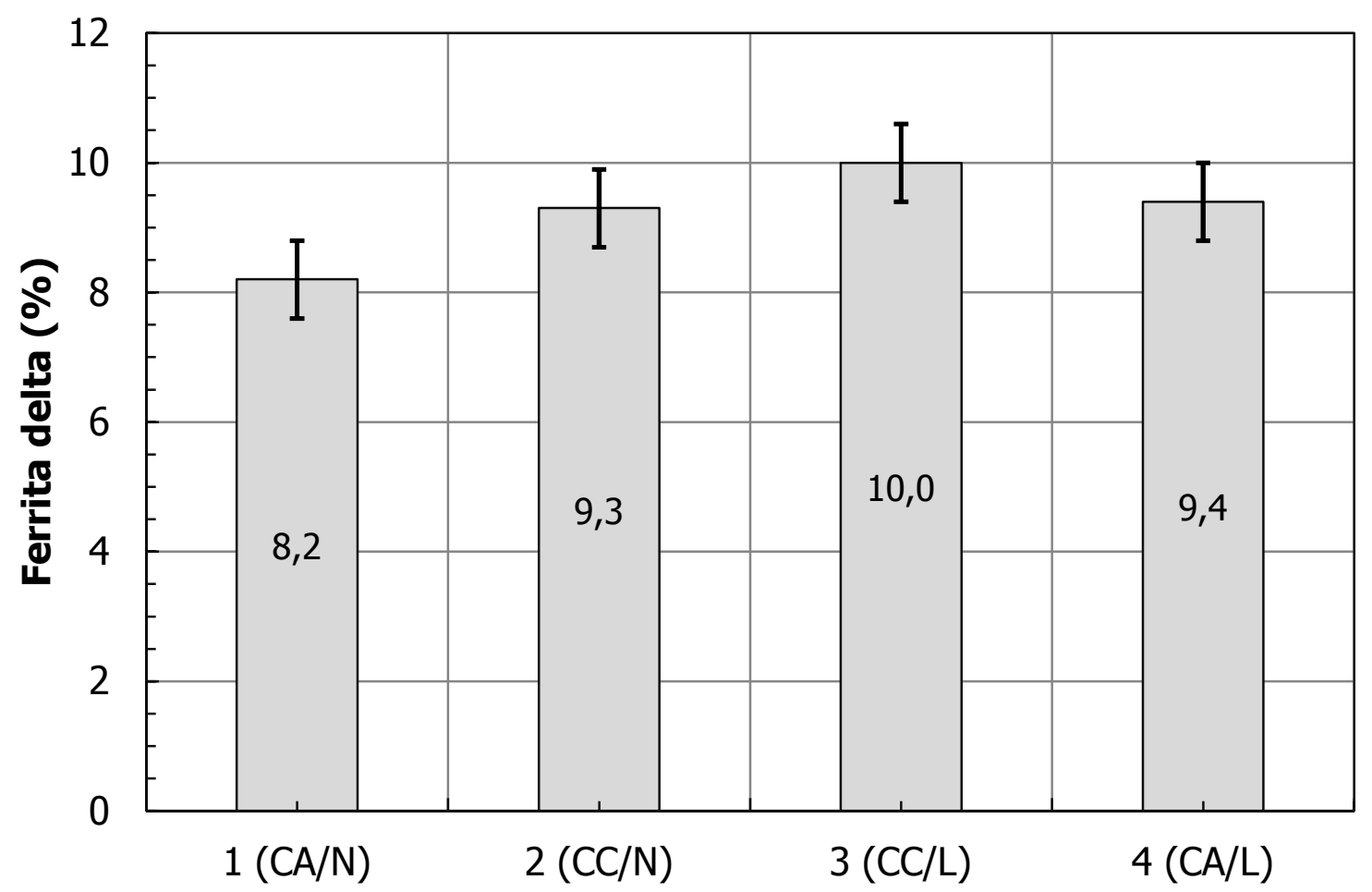
4.

Figura 4.10: Fração volumétrica média de ferrita nas juntas soldadas dos corpos de prova de 1 a

De acordo com a literatura [63], a morfologia da ferrita varia também em função da fração volumétrica da mesma, conforme a figura 2.30. Assim, espera-se que na maioria das regiões medidas sejam encontradas tanto ferrita vermicular quanto acicular, exceto nos locais onde foi medida uma fração maior que $10 \%$ onde se espera uma predominância de ferrita acicular.

A fratura em aplicações criogênicas tende a ocorrer no cordão de solda devido à maior fração volumétrica de ferrita nesta região, associada à quantidade e tamanho de micro inclusões de escória. O mecanismo de falha predominante a baixas temperaturas é por clivagem (que exibe superfície relativamente plana) em aços inoxidáveis ferríticos e, em aços inoxidáveis austeníticos, a transição dúctil-frágil ocorre de forma mais acentuada somente a temperaturas extremamente baixas, próximas de $-269^{\circ} \mathrm{C}$. Assim, quando a fração volumétrica de ferrita estiver elevada, a tenacidade pode ser comprometida. A figura 4.11 apresenta uma fractografia mostrando a clivagem da ferrita e a presença de alvéolos, típico de fratura dúctil da austenita, o que vai de acordo com estudos anteriores [31, 33, 34]. Para confirmar 
que a região correspondia as duas fases, foi feita a análise química por dispersão de energia, que confirmou a presença das duas fases.

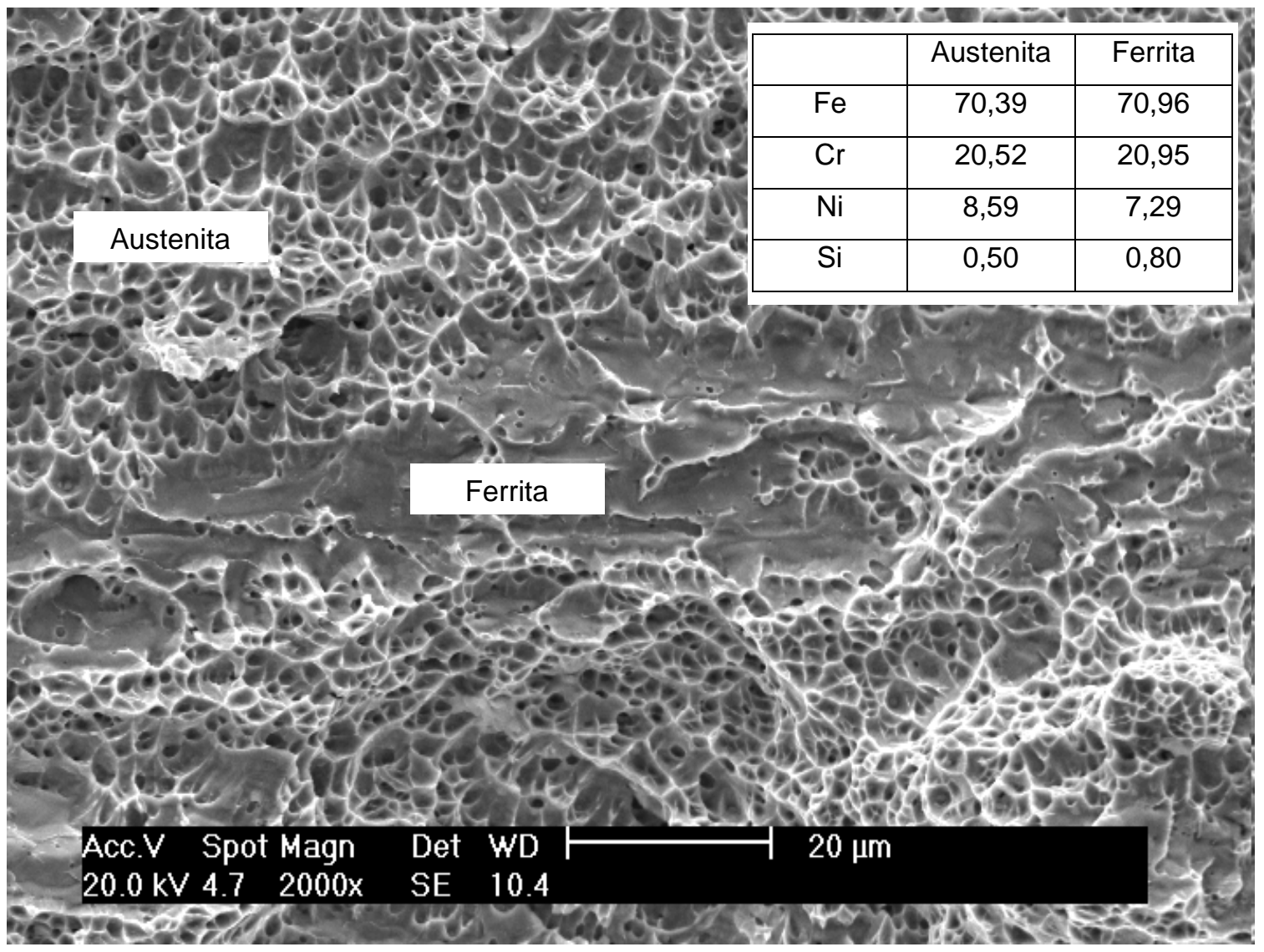

Figura 4.11: Fractografia de um corpo de prova Charpy $\mathrm{V}$ a $-100^{\circ} \mathrm{C}$ mostrando a clivagem da ferrita e a fratura dúctil da austenita. São apresentadas também as composições químicas das duas regiões. MEV, elétrons secundários.

\subsubsection{Micrografias dos cordões de solda.}

a) Micro inclusões de escória 
A figura 4.12 mostra uma região da fratura do corpo de prova do ensaio Charpy $\mathrm{V}$ sem ataque, para evidenciar a presença de inclusões no cordão de solda. A fratura ocorreu na zona fundida.

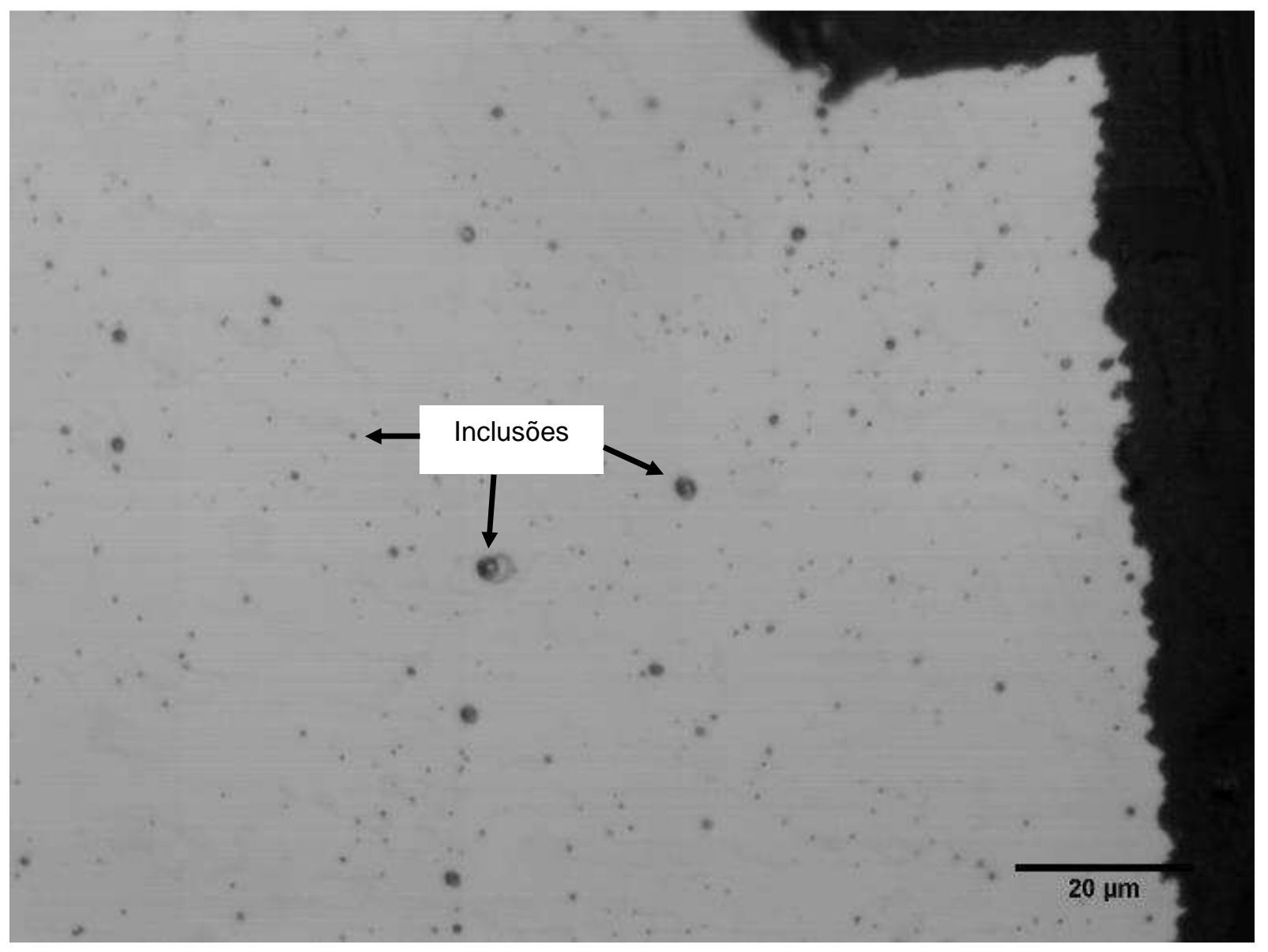

Figura 4.12: Fotografia sem ataque de uma região fraturada na zona fundida do corpo de prova 3 Charpy $\mathrm{V}$, mostrando a presença de inclusões. Microscópio óptico.

As inclusões atuam como concentradores de tensão, sendo possíveis pontos de nucleação de trincas. Assim, quanto maior a quantidade de inclusões, menor a resistência ao impacto do material. A presença de inclusões no cordão de solda, aliada ao maior teor de ferrita no mesmo, torna que esta região seja mais propícia a se fraturar nos ensaios Charpy realizados a baixa temperatura.

b) Morfologia da ferrita 
Através dos valores de composição química apresentada na tabela 4.8 foi possível calcular a relação $\mathrm{Cr}_{\text {eq }} / \mathrm{Ni}_{\text {eq. }}$. Os valores obtidos através do cálculo usual e de Hammar e Svenson estão apresentados na tabela 4.11. Observa-se que através do cálculo de Hammar e Svenson todas as relações $\mathrm{Cr}_{\mathrm{eq}} / \mathrm{Ni}_{\text {eq }}$ estão ligeiramente inferiores aos valores obtidos pelo cálculo usual, de forma que a diferença entre eles não é suficiente para interferir na microestrutura esperada em função da relação $\mathrm{Cr}_{\text {eq }} / \mathrm{Ni}_{\text {eq. }}$. Desta forma, consideraremos apenas os valores obtidos pelo cálculo usual. $\mathrm{Na}$ figura 4.13 estão os valores de $\mathrm{Cr}_{\mathrm{eq}} / \mathrm{Ni}_{\text {eq }}$ obtidos pelo método usual. $\mathrm{A}$ morfologia de ferrita prevista pelos valores da relação $\mathrm{Cr}_{\text {eq }} / \mathrm{Ni}_{\text {eq }}$ está de acordo com a observada nos corpos de prova, conforme as figuras 4.14 e 4.15 .

Tabela 4.11: Relações $\mathrm{Cr}_{\mathrm{eq}} / \mathrm{Ni}_{\text {eq }}$ e morfologias de ferrita previstas para os corpos de prova de 1 a 4 através do cálculo usual e pelo cálculo proposto por Hammar e Svenson.

\begin{tabular}{|c|c|c|c|c|}
\hline $\begin{array}{l}\text { Corpo de } \\
\text { prova }\end{array}$ & Cordão & $\mathrm{Cr}_{\mathrm{eq}} / \mathrm{Ni}_{\mathrm{eq}}$ & Creq/Nieq (H-S) & Morfologia ferrita \\
\hline \multirow{2}{*}{$1(\mathrm{CA} / \mathrm{N})$} & Face & 1,873 & 1,768 & $\begin{array}{l}\text { Vermicular ou } \\
\text { acicular }\end{array}$ \\
\hline & Raiz & 1,891 & 1,784 & $\begin{array}{l}\text { Vermicular ou } \\
\text { acicular }\end{array}$ \\
\hline \multirow{2}{*}{$2(\mathrm{CC} / \mathrm{N})$} & Face & 1,844 & 1,742 & $\begin{array}{l}\text { Vermicular ou } \\
\text { acicular }\end{array}$ \\
\hline & Raiz & 1,885 & 1,783 & $\begin{array}{l}\text { Vermicular ou } \\
\text { acicular }\end{array}$ \\
\hline \multirow{2}{*}{$3(\mathrm{CC} / \mathrm{L})$} & Face & 1,834 & 1,762 & $\begin{array}{l}\text { Vermicular ou } \\
\text { acicular }\end{array}$ \\
\hline & Raiz & 1,834 & 1,763 & $\begin{array}{l}\text { Vermicular ou } \\
\text { acicular }\end{array}$ \\
\hline \multirow{2}{*}{$4(\mathrm{CA} / \mathrm{L})$} & Face & 1,900 & 1,796 & $\begin{array}{l}\text { Vermicular ou } \\
\text { acicular }\end{array}$ \\
\hline & Raiz & 1,902 & 1,794 & $\begin{array}{l}\text { Vermicular ou } \\
\text { acicular }\end{array}$ \\
\hline
\end{tabular}




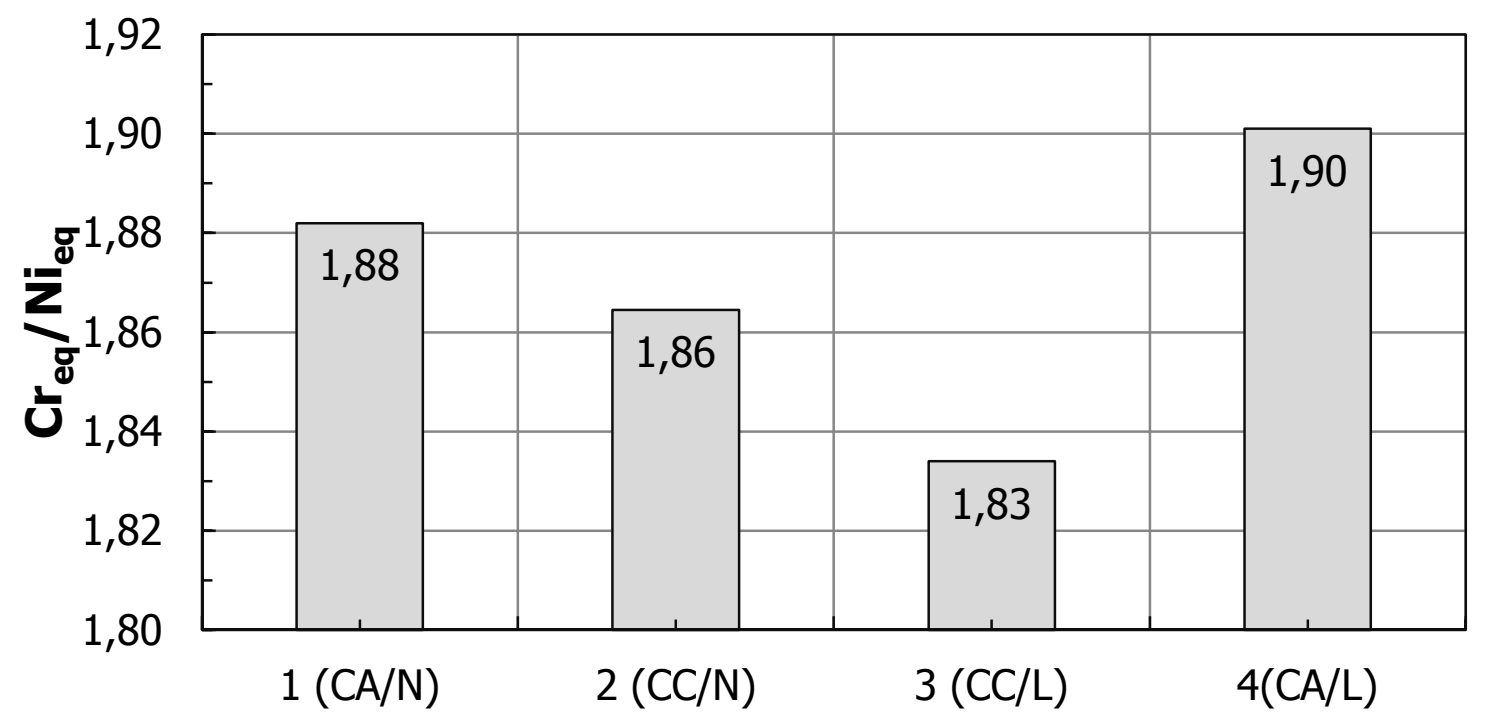

Figura 4.13: Relação $\mathrm{Cr}_{\mathrm{eq}} / \mathrm{Ni}_{\mathrm{eq}}$ para as diferentes condições de soldagem.

Conforme exposto anteriormente, quanto mais próxima a relação $\mathrm{Cr}_{\mathrm{eq}} / \mathrm{Ni}_{\text {eq }}$ estiver de 1,95 , maior a tendência de formação de ferrita acicular ao invés de ferrita vermicular. Quando a relação $\mathrm{Cr}_{\text {eq }} / \mathrm{Ni}_{\text {eq }}$ se aproxima de 1,80, há tendência de maior formação de ferrita vermicular que de ferrita acicular.

A partir da tabela 4.11, nota-se que as soldagens realizadas com corrente alternada apresentam uma relação $\mathrm{Cr}_{\text {eq }} / \mathrm{Ni}_{\text {eq }}$ superior às soldagens realizadas em corrente contínua, favorecendo a formação de ferrita acicular. Assim, espera-se que nestes casos os corpos de prova absorvam maior quantidade de energia durante a fratura dos ensaios Charpy a $-100^{\circ} \mathrm{C}$. No caso das soldagens efetuadas em corrente contínua, a relação $\mathrm{Cr}_{\text {eq }} / \mathrm{Ni}_{\text {eq }}$ é mais baixa ao se utilizar o fluxo ligado. A soldagem em (CC/L) apresentou a relação $\mathrm{Cr}_{\text {eq }} / \mathrm{Ni}_{\text {eq }}$ mais baixa entre as condições testadas, $\mathrm{O}$ que favorece a formação de ferrita vermicular ao invés de ferrita acicular.

A figura 4.14 apresenta uma micrografia do cordão de solda proveniente da soldagem em (CC/L), na qual é possível observar a morfologia da ferrita. 


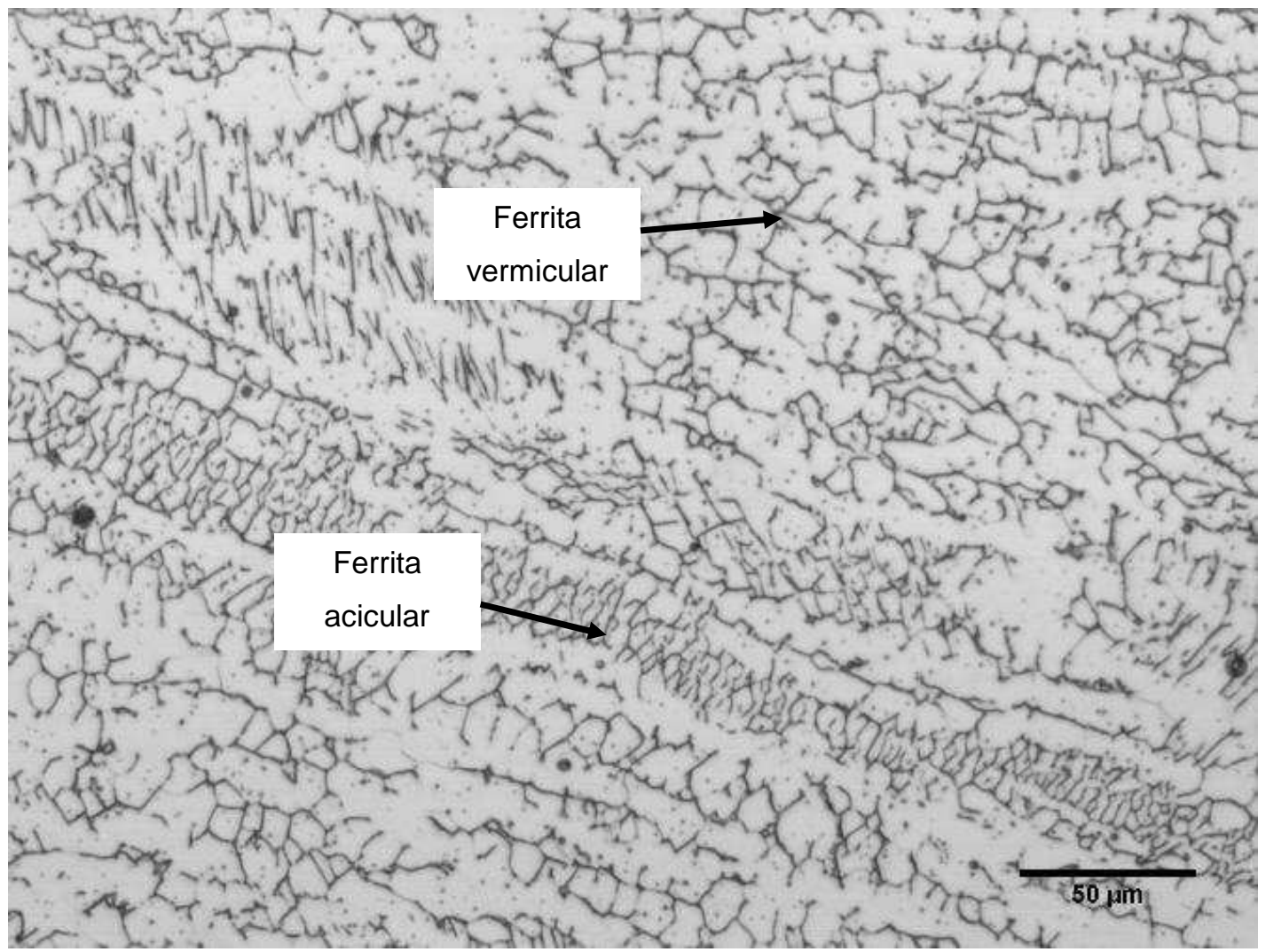

Figura 4.14: Micrografia do cordão de solda na qual se observam as morfologias da ferrita para o corpo de prova 3 (CC/L). Ataque eletrolítico, ácido oxálico 10\%. Microscópio óptico.

Nota-se a presença de ferrita acicular e de ferrita vermicular em uma matriz austenítica, conforme previsto na literatura [65] para uma microestrutura do tipo $B$ (isto é, solidificação ferrítico-austenítica para $\left.1,48<(\mathrm{Cr} / \mathrm{Ni})_{\text {eq }}<1,95\right)$. A microestrutura observada na figura 4.14 é similar à apresentada na figura 2.35 , porém com predominância de ferrita vermicular - o que leva a crer que a relação $\mathrm{Cr}_{\text {eq }} / \mathrm{Ni}_{\text {eq }}$ neste experimento é menor que na literatura.

A figura 4.15 mostra em detalhe uma região de fronteira entre as morfologias típicas de ferrita nos cordões de solda. Nela é possível notar a presença de ferrita acicular (acima, à esquerda) e vermicular (abaixo, à direita), previstas pelo modo de solidificação para $1,48<(\mathrm{Cr} / \mathrm{Ni})_{\text {eq }}<1,95$. Ao centro, há a presença de uma micro inclusão de escória. 


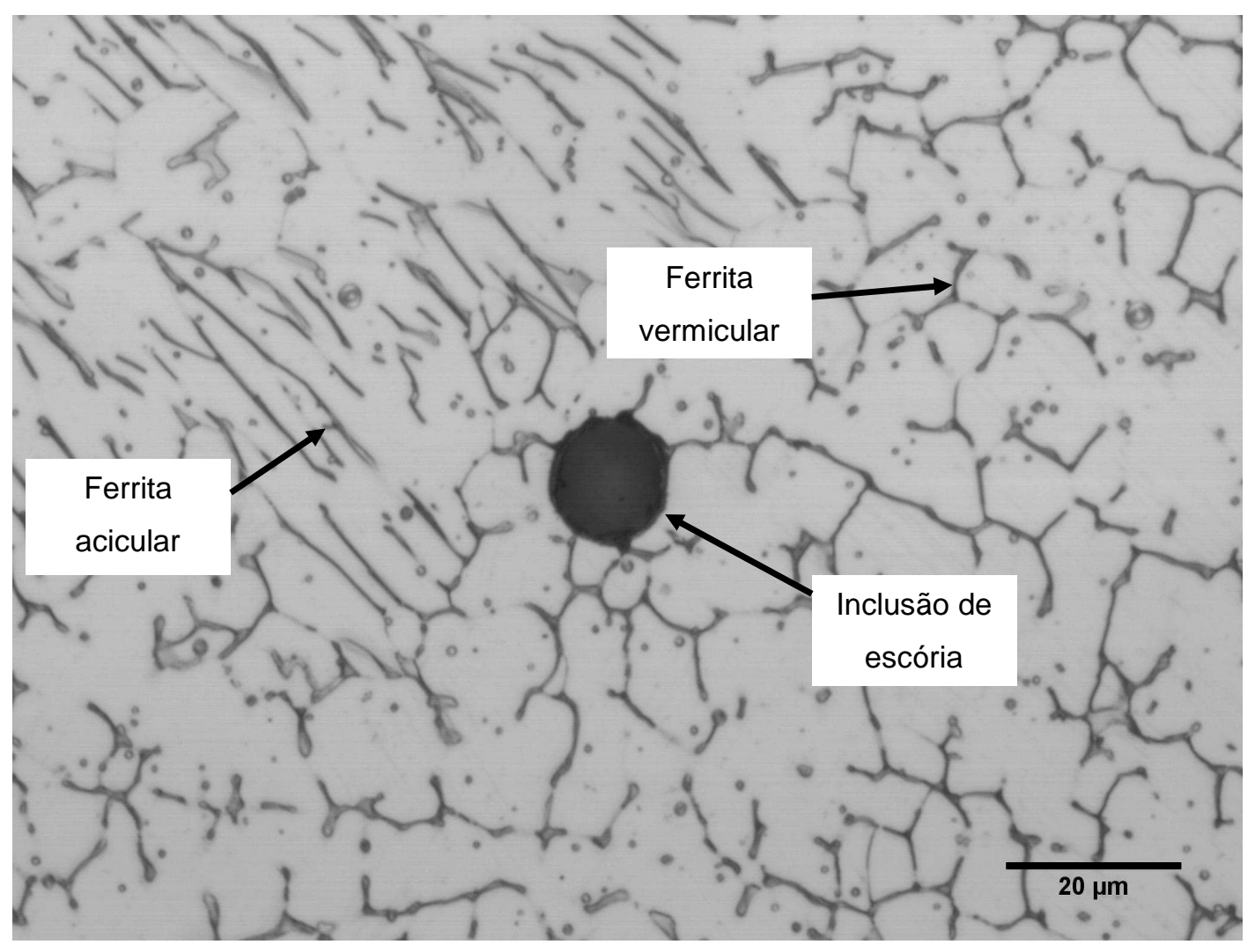

Figura 4.15: Micrografia do cordão de solda mostrando as morfologias da ferrita e a presença de uma micro inclusão de escória. Ataque eletrolítico, ácido oxálico 10\%. Microscópio óptico.

b) Microscopia eletrônica de varredura

A figura 4.16 ilustra uma transição de microestrutura na zona fundida do corpo de prova 4. A região à esquerda se encontra próxima à fratura, e a região à direita, mais afastada. Foi realizada análise química por energia de dispersão em ambas as regiões, cujos resultados se encontram na tabela 4.12. A morfologia predominante da ferrita na região à esquerda é vermicular, enquanto na região à direita é acicular. Isto vai de acordo com a maior fragilidade da ferrita vermicular a baixas temperaturas em relação à ferrita acicular. 


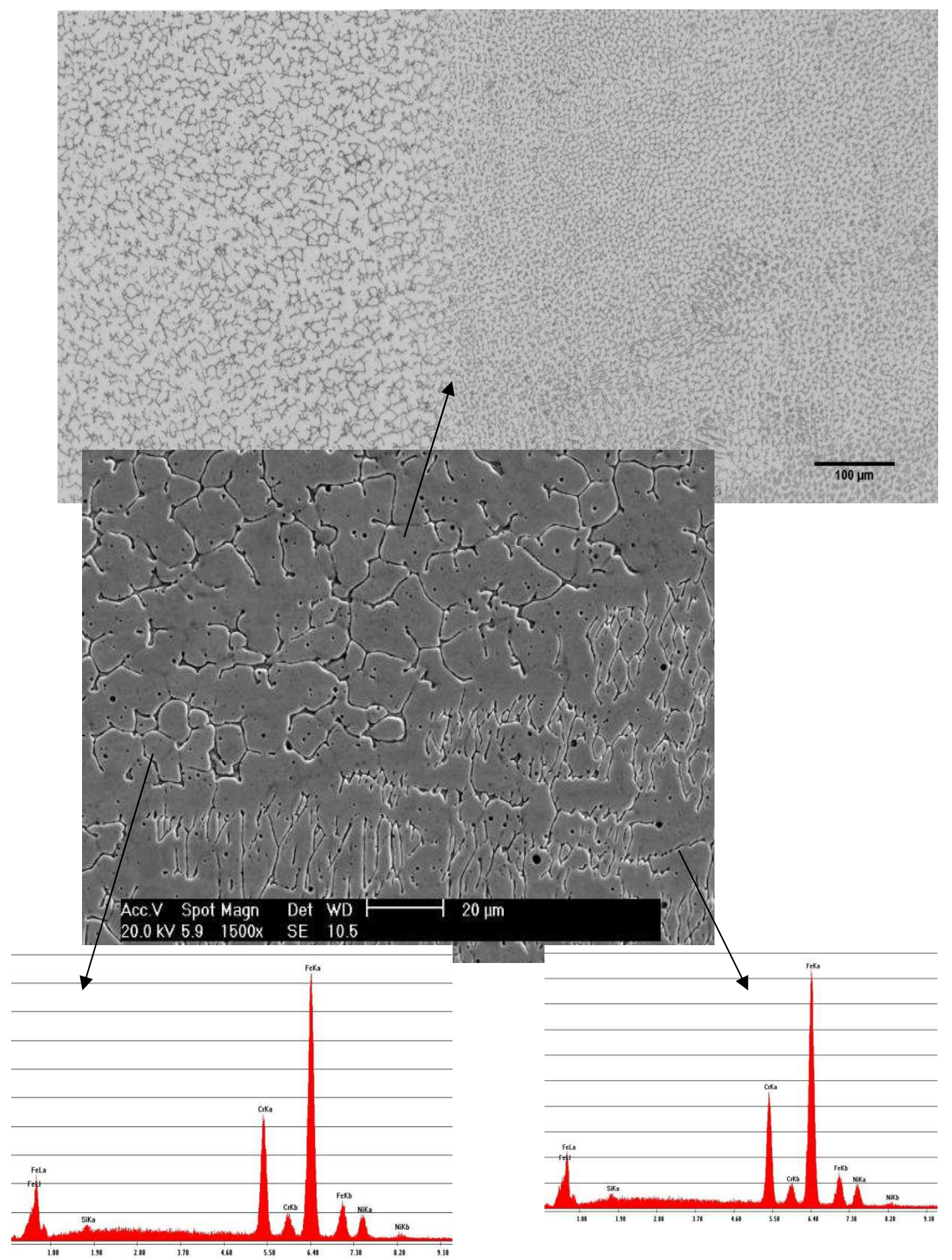

Figura 4.16: Transição de microestruturas na zona fundida do corpo de prova 4. MEV, elétrons secundários. 
Tabela 4.12: Elementos nas microestruturas das diferentes regiões da zona fundida do corpo de prova 4.

\begin{tabular}{|c|c|c|}
\hline \multirow{2}{*}{ Elemento } & \multicolumn{2}{|c|}{$\%$ At } \\
\cline { 2 - 3 } & Próximo à fratura & Afastado da fratura \\
\hline $\mathrm{Si}$ & 1,37 & 1,60 \\
\hline $\mathrm{Cr}$ & 20,95 & 20,24 \\
\hline $\mathrm{Fe}$ & 68,43 & 69,18 \\
\hline $\mathrm{Ni}$ & 9,25 & 8,98 \\
\hline
\end{tabular}

A partir dos resultados da tabela 4.12, calcularam-se os valores de níquel e cromo equivalente para as duas regiões, cujos valores se encontram na tabela 4.13.

Tabela 4.13: Níquel e cromo equivalentes para as duas regiões de morfologias distintas na zona fundida do corpo de prova 4.

\begin{tabular}{|c|c|c|c|}
\hline Região & $\mathrm{Ni}_{\text {eq }}$ & $\mathrm{Cr}_{\text {eq }}$ & $\mathrm{Cr}_{\text {eq }} / \mathrm{Ni}_{\text {eq }}$ \\
\hline Próxima à trinca & 9,25 & 23,00 & 2,49 \\
\hline Afastada da trinca & 8,98 & 22,64 & 2,52 \\
\hline
\end{tabular}

A região mais afastada da trinca apresenta uma relação $\mathrm{Cr}_{e q} / \mathrm{Ni}_{\text {eq }}$ ligeiramente inferior à região mais próxima à trinca. Para estas relações, ambas as regiões tendem a apresentar ferrita acicular, que no caso não ocorre na região à esquerda. Neste caso, a morfologia da ferrita deve ter sido definida pela direção do fluxo de calor em relação à direção $<100>$ Y: A ferrita delta à esquerda, que pela relação $\mathrm{Cr}_{\text {eq }} / \mathrm{Ni}_{\text {eq }}$ deveria apresentar morfologia acicular, apresenta uma morfologia vermicular devido ao não alinhamento entre a direção $<100>$ y e o fluxo de calor. Conforme a poça de fusão se desloca durante a soldagem, a direção do fluxo de calor se altera, o que possibilitou a formação de ferrita acicular na região à direita.

\subsection{Propriedades mecânicas}




\subsubsection{Ensaio de dobramento lateral da junta soldada}

Nos ensaios de dobramento lateral realizados para os corpos de prova 1 a 4 , nenhum dos ensaios realizados apresentou trincas, conforme se observa na figura 4.17. Assim sendo, não foram observadas rupturas e os procedimentos de soldagem foram aprovados neste teste. Os dados dos ensaios estão na tabela 4.14.
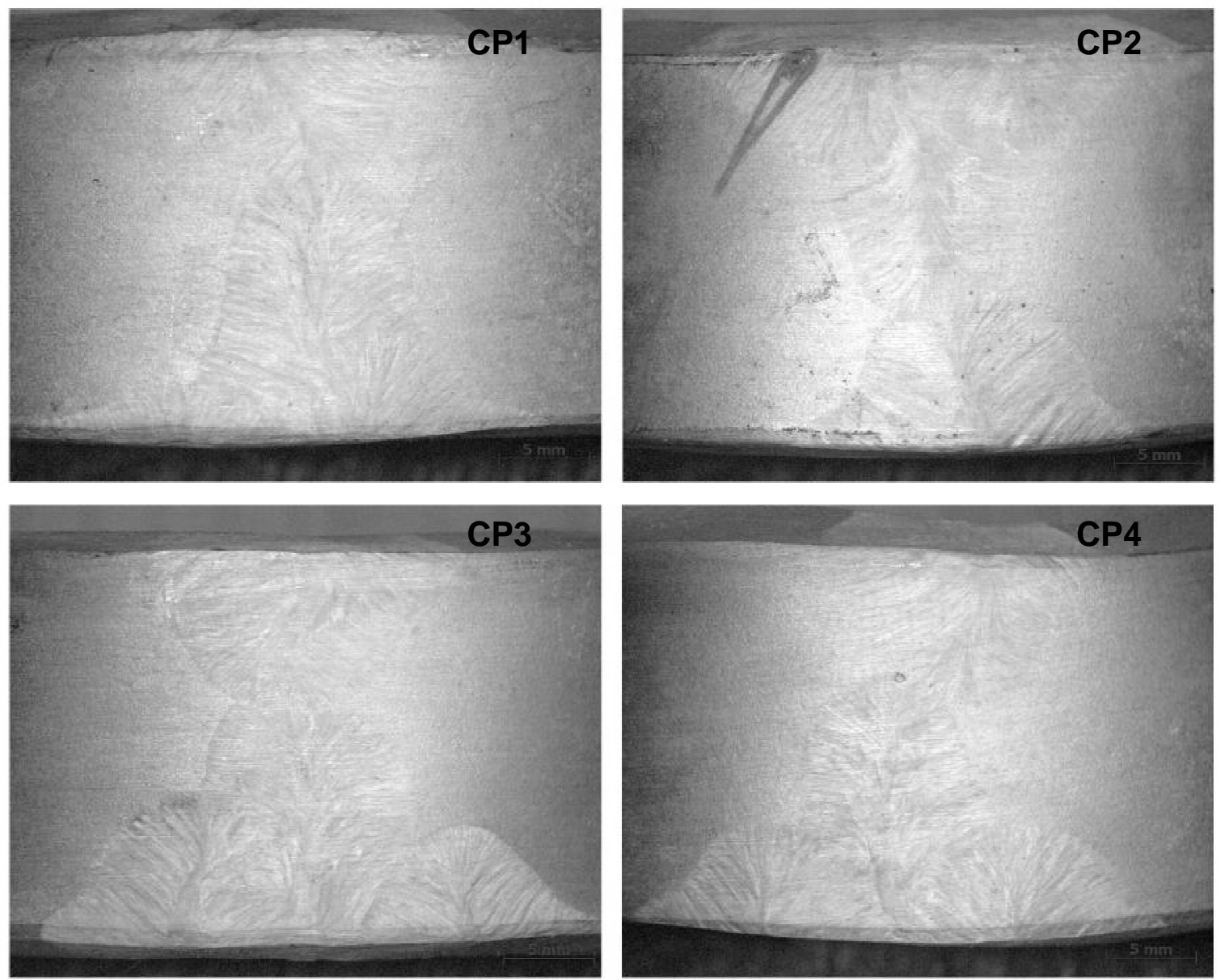

Figura 4.17: Corpos de prova após ensaio de dobramento transversal. 
Tabela 4.14: Dados dos ensaios de dobramento lateralpara os corpos de prova 1 a 4.

\begin{tabular}{|c|c|c|c|c|c|c|}
\hline $\begin{array}{l}\text { Corpo } \\
\text { de } \\
\text { prova }\end{array}$ & Ensaio & $\begin{array}{l}\text { Dimensões } \\
(\mathrm{mm})\end{array}$ & $\begin{array}{l}\text { Diâmetro } \\
\text { do cutelo } \\
\text { (mm) }\end{array}$ & $\begin{array}{c}\text { Distância } \\
\text { entre } \\
\text { roletes } \\
(\mathrm{mm})\end{array}$ & $\begin{array}{l}\text { Ângulo de } \\
\text { dobramento } \\
\text { (graus) }\end{array}$ & Resultado \\
\hline 1 & 1 & \multirow{8}{*}{$\begin{array}{c}24,00 x \\
10,00\end{array}$} & \multirow{8}{*}{38,10} & \multirow{8}{*}{60,40} & \multirow{8}{*}{180} & \multirow{8}{*}{$\begin{array}{l}\text { Sem } \\
\text { fissuras }\end{array}$} \\
\hline$(\mathrm{CA} / \mathrm{N})$ & 2 & & & & & \\
\hline \multirow{2}{*}{$\begin{array}{c}2 \\
(\mathrm{CC} / \mathrm{N})\end{array}$} & 1 & & & & & \\
\hline & 2 & & & & & \\
\hline \multirow{2}{*}{$\begin{array}{c}3 \\
(\mathrm{CC} / \mathrm{L})\end{array}$} & 1 & & & & & \\
\hline & 2 & & & & & \\
\hline \multirow{2}{*}{$\begin{array}{c}4 \\
(\mathrm{CA} / \mathrm{L})\end{array}$} & 1 & & & & & \\
\hline & 2 & & & & & \\
\hline
\end{tabular}

\subsubsection{Ensaio de tração da junta soldada}

Para os ensaios de tração, realizados para os corpos de prova de 1 a 4 , foram obtidos os resultados da tabela 4.15. Em todos os ensaios a ruptura ocorreu na solda, mas o limite de resistência obtido foi superior ao limite mínimo especificado para o material. 
Tabela 4.15: Dados dos ensaios de tração para os corpos de prova 1 a 4.

\begin{tabular}{|c|c|c|c|c|c|c|c|}
\hline \multirow{2}{*}{$\begin{array}{l}\text { Corpo } \\
\text { de } \\
\text { prova }\end{array}$} & \multirow{2}{*}{ Ensaio } & \multirow{2}{*}{$\begin{array}{l}\text { Dimensões } \\
(\mathrm{mm})\end{array}$} & \multirow{2}{*}{$\begin{array}{l}\text { Secção } \\
\left(\mathrm{mm}^{2}\right)\end{array}$} & \multicolumn{2}{|c|}{$\begin{array}{l}\text { Limite de } \\
\text { resistência (MPa) }\end{array}$} & \multirow{2}{*}{$\begin{array}{c}\text { Limite } \\
\text { mínimo } \\
\text { especificado } \\
(\mathrm{MPa})\end{array}$} & \multirow{2}{*}{$\begin{array}{l}\text { Local } \\
\text { de } \\
\text { ruptura }\end{array}$} \\
\hline & & & & Medido & Média & & \\
\hline \multirow{2}{*}{$\begin{array}{c}1 \\
(\mathrm{CA} / \mathrm{N})\end{array}$} & 1 & $\begin{array}{c}19,30 x \\
20,70\end{array}$ & 399,51 & 601 & \multirow{2}{*}{$606 \pm 7$} & \multirow{8}{*}{515} & \multirow{8}{*}{$\begin{array}{l}\mathrm{Na} \\
\text { solda }\end{array}$} \\
\hline & 2 & $\begin{array}{c}19,20 \times \\
20,70\end{array}$ & 397,44 & 611 & & & \\
\hline \multirow{2}{*}{$\left(\begin{array}{c}2 \\
(\mathrm{CC} / \mathrm{N})\end{array}\right.$} & 1 & $\begin{array}{c}19,00 x \\
20,70\end{array}$ & 393,30 & 606 & \multirow{2}{*}{$607 \pm 1$} & & \\
\hline & 2 & $\begin{array}{l}19,20 x \\
20,70\end{array}$ & 397,44 & 608 & & & \\
\hline \multirow{2}{*}{$\left(\begin{array}{c}3 \\
(\mathrm{CC} / \mathrm{L})\end{array}\right.$} & 1 & $\begin{array}{c}19,15 \times \\
21,20\end{array}$ & 405,98 & 601 & \multirow{2}{*}{$598 \pm 4$} & & \\
\hline & 2 & $\begin{array}{c}19,30 \times \\
21,20\end{array}$ & 409,16 & 596 & & & \\
\hline \multirow{2}{*}{$\begin{array}{c}4 \\
(\mathrm{CA} / \mathrm{L})\end{array}$} & 1 & $\begin{array}{c}19,25 x \\
20,40\end{array}$ & 392,70 & 604 & \multirow{2}{*}{$606 \pm 3$} & & \\
\hline & 2 & $\begin{array}{c}19,35 \times \\
20,35\end{array}$ & 393,77 & 608 & & & \\
\hline
\end{tabular}

Dos resultados médios obtidos acima, pode-se afirmar que o limite de resistência médio do corpo de prova $3(\mathrm{CC} / \mathrm{L})$ é menor que dos corpos de prova $2(\mathrm{CC} / \mathrm{L})(1,4 \%)$ e 4 (CA/L) $(1,2 \%)$ a um nível de significância de $1 \%$. O elevado teor de oxigênio no metal de solda do corpo de prova 3 (CC/L) é um indicador de sua elevada quantidade de micro inclusões em sua microestrutura e, consequentemente, este corpo de prova tende a apresentar um limite de resistência inferior aos demais.

A relação entre limite de resistência e teor de oxigênio no metal de solda se confirma na figura 4.18, a qual apresenta o tamanho médio do alvéolo na superfície de fratura medido por microscopia eletrônica de varredura para as quatro condições de soldagem. Conforme o tamanho médio dos alvéolos diminui, a taxa de nucleação 
de micro vazios em inclusões aumenta, o que significa uma maior fração volumétrica de inclusões e, consequentemente, alto teor de oxigênio no cordão de solda (como no corpo de prova $3(\mathrm{CC} / \mathrm{L})$ ). Após a nucleação, os alvéolos crescem e coalescem até a fratura. As outras três condições de soldagem apresentaram tamanhos médios de alvéolos próximos entre si, o que vai de acordo com os resultados nos ensaios de tração.

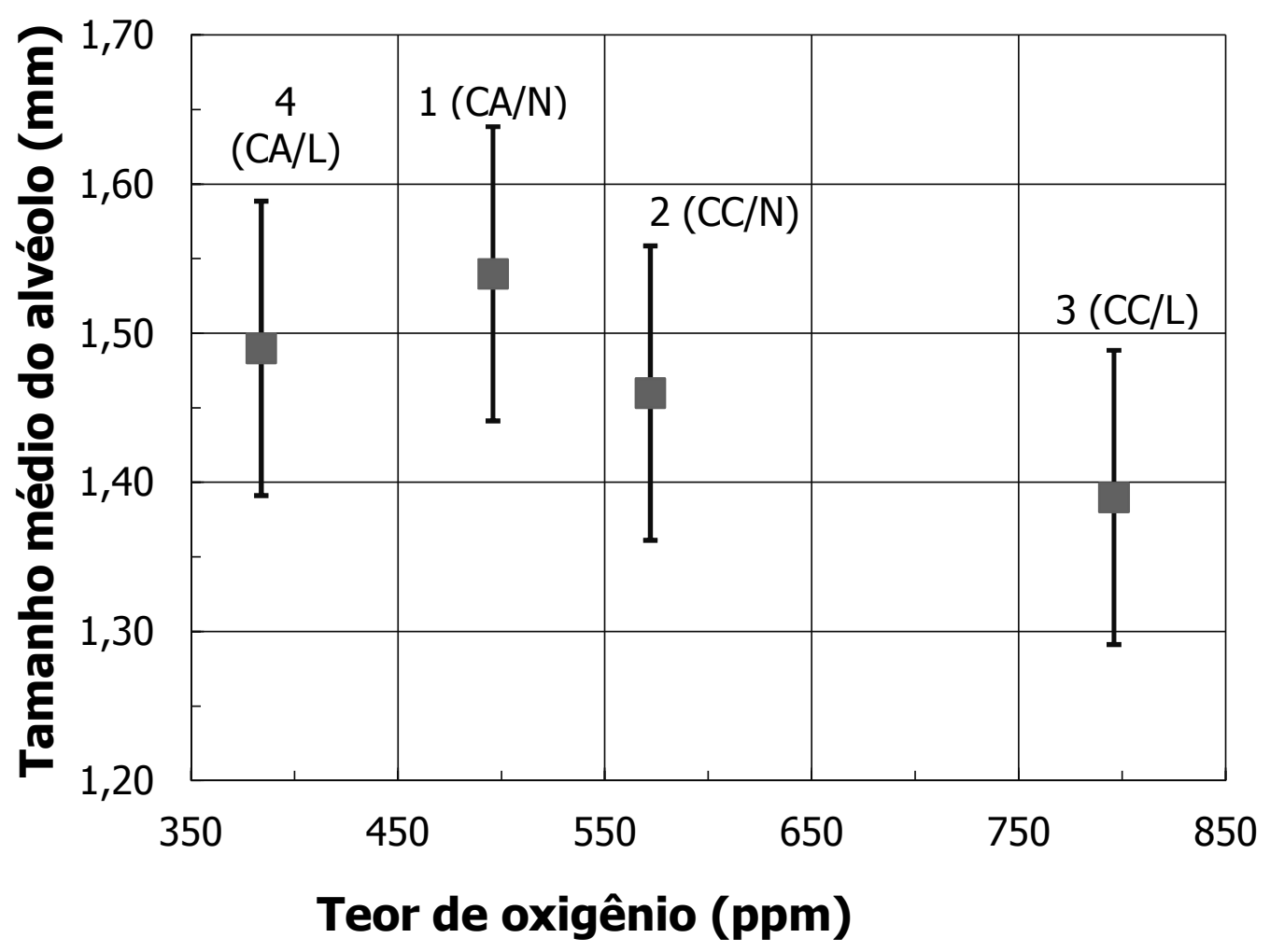

Figura 4.18: Relação entre tamanho médio do alvéolo e teor de oxigênio no metal de solda.

\subsubsection{Ensaio de impacto (Charpy V) de regiões da junta soldada}

Os resultados dos ensaios Charpy estão na tabela 4.16. Todos os ensaios foram realizados à temperatura de $-100^{\circ} \mathrm{C}$, sendo o entalhe do tipo V2 x $10 \times 10$. 
Tabela 4.16: Resultados dos ensaios Charpy $\mathrm{V} \mathrm{a}-100^{\circ} \mathrm{C}$.

\begin{tabular}{|c|c|c|c|c|c|c|c|c|}
\hline \multirow{2}{*}{$\begin{array}{l}\text { Corpo } \\
\text { de prova }\end{array}$} & \multirow{2}{*}{$\begin{array}{c}\text { Local do } \\
\text { cordão } \\
\text { de solda }\end{array}$} & \multirow{2}{*}{$\begin{array}{l}\text { Dimensão } \\
\quad(\mathrm{mm})\end{array}$} & \multicolumn{3}{|c|}{ Energia absorvida } & \multicolumn{3}{|c|}{ Expansão lateral } \\
\hline & & & $\begin{array}{l}\text { Medida } \\
\text { (J) }\end{array}$ & \multicolumn{2}{|c|}{ Média (J) } & $\begin{array}{c}\text { Obtida } \\
\text { (mm) }\end{array}$ & \multicolumn{2}{|c|}{ Média (mm) } \\
\hline \multirow{10}{*}{$1(\mathrm{CA} / \mathrm{N})$} & \multirow{5}{*}{ Raiz } & 10,007 & 54 & \multirow{5}{*}{$59 \pm 4$} & \multirow{10}{*}{$65 \pm 8$} & 0,803 & \multirow{5}{*}{$0,775 \pm 0,060$} & \multirow{10}{*}{$0,7 \pm 0,1$} \\
\hline & & 10,005 & 63 & & & 0,695 & & \\
\hline & & 10,012 & 62 & & & 0,808 & & \\
\hline & & 10,011 & 59 & & & 0,839 & & \\
\hline & & 10,014 & 58 & & & 0,730 & & \\
\hline & \multirow{5}{*}{ Face } & 9,984 & 73 & \multirow{5}{*}{$71 \pm 5$} & & 0,686 & \multirow{5}{*}{$0,792 \pm 0,131$} & \\
\hline & & 9,917 & 74 & & & 0,846 & & \\
\hline & & 10,004 & 65 & & & 0,747 & & \\
\hline & & 9,985 & 77 & & & 0,995 & & \\
\hline & & 9,915 & 67 & & & 0,685 & & \\
\hline \multirow{10}{*}{$2(\mathrm{CC} / \mathrm{N})$} & \multirow{5}{*}{ Raiz } & 9,973 & 52 & \multirow{5}{*}{$54 \pm 3$} & \multirow{10}{*}{$56 \pm 5$} & 0,659 & \multirow{5}{*}{$0,750 \pm 0,086$} & \multirow{10}{*}{$0,74 \pm 0,07$} \\
\hline & & 9,960 & 58 & & & 0,690 & & \\
\hline & & 10,006 & 51 & & & 0,809 & & \\
\hline & & 9,975 & 56 & & & 0,725 & & \\
\hline & & 10,003 & 52 & & & 0,866 & & \\
\hline & \multirow{5}{*}{ Face } & 10,010 & 52 & \multirow{5}{*}{$57 \pm 6$} & & 0,740 & & \\
\hline & & 10,027 & 60 & & & 0,756 & & \\
\hline & & 10,030 & 51 & & & 0,670 & $0,730 \pm 0,053$ & \\
\hline & & 9,990 & 64 & & & 0,685 & & \\
\hline & & 10,017 & 60 & & & 0,798 & & \\
\hline & & 7,518 & 40 & & & 0,743 & & \\
\hline & & 7,485 & 34 & & & 0,733 & & \\
\hline & Raiz & 7,482 & 34 & $37 \pm 3$ & & 0,736 & $0,740 \pm 0,007$ & \\
\hline & & 7,527 & 38 & & & 0,737 & & \\
\hline $5(0) / 1)$ & & 7,490 & 41 & & $26+5$ & 0,750 & & $066+000$ \\
\hline $3(\mathrm{C} C / \mathrm{L})$ & & 7,522 & 34 & & $36 \pm 5$ & 0,590 & & $0,00 \pm 0,0 y$ \\
\hline & & 7,513 & 43 & & & 0,600 & & \\
\hline & Face & 7,518 & 31 & $35 \pm 6$ & & 0,587 & $0,583 \pm 0,039$ & \\
\hline & & 7,491 & 28 & & & 0,517 & & \\
\hline & & 7,499 & 38 & & & 0,621 & & \\
\hline & & 9,990 & 55 & & & 0,710 & & \\
\hline & & 9,997 & 62 & & & 0,994 & & \\
\hline & Raiz & 10,005 & 50 & $57 \pm 5$ & & 0,819 & $0,744 \pm 0,183$ & \\
\hline & & 10,020 & 59 & & & 0,705 & & \\
\hline $1(r \wedge(1)$ & & 10,006 & 57 & & $52+6$ & 0,494 & & $07+01$ \\
\hline $4(\mathrm{UA} / \mathrm{L})$ & & 10,004 & 43 & & उउI0 & 0,621 & & $0, / \pm U, 1$ \\
\hline & & 9,990 & 56 & & & 0,670 & & \\
\hline & Face & 10,013 & 44 & $50 \pm 6$ & & 0,624 & $0,643 \pm 0,023$ & \\
\hline & & 9,992 & 53 & & & 0,636 & & \\
\hline & & 10,016 & 53 & & & 0,664 & & \\
\hline
\end{tabular}


Excetuando-se o corpo de prova $1(\mathrm{CA} / \mathrm{N})$, todos os corpos de prova absorveram em média a mesma quantidade de energia na raiz e na face com um nível de significância de 1\% (este nível será adotado nas próximas comparações estatísticas entre médias). Os testes estatísticos de comparação de médias podem ser observados no anexo A. Portanto em geral, ambos os cordões de face e raiz absorvem a mesma quantidade de energia para os mesmos parâmetros de soldagem.

A $-100{ }^{\circ} \mathrm{C}$, os mecanismos predominantes de fratura são a coalescência de alvéolos na austenita e a clivagem na ferrita. Ou seja, a esta temperatura ocorre um escoamento em larga escala, na qual a ruptura apresenta certa ductilidade, que pode ser relacionada à expansão lateral.

A maior fragilidade do corpo de prova $3(\mathrm{CC} / \mathrm{L})$ tanto para o cordão de solda na raiz quanto na face, além de sua menor expansão lateral, estão relacionadas ao teor mais elevado de oxigênio, conforme apresentado na tabela 4.6. Este resultado pode ser explicado pelo mesmo mecanismo apresentado no teste de tração: o teor de oxigênio é um fator que afeta o resultado, particularmente na região austenítica do cordão de solda, onde há uma grande quantidade de inclusões de óxidos.

Como estes ensaios foram efetuados a baixa temperatura, a clivagem da ferrita pode ocorrer durante a propagação da trinca. A ferrita pode se fraturar por um mecanismo de maclação no sistema de escorregamento $\{112\}<111>$ ou nos planos \{100\}. A família de direções de maclação da ferrita são as mesmas da relação de orientação KS na ferrita. Esta coincidência na direção pode alterar a resistência da morfologia da ferrita a baixa temperatura, sugerindo menor resistência à ferrita acicular. Porém, este não é o caso, pois se deve levar em conta o caminho médio da trinca durante a clivagem da ferrita. Portanto, a ferrita vermicular apresenta um caminho médio maior que a ferrita acicular e, consequentemente, a ferrita vermicular é menos tenaz que a ferrita acicular, o que vai de acordo com Inoue et al. e Kamiya et al. [32, 59]. A ferrita acicular possui resistência à fratura superior à ferrita vermicular a temperaturas criogênicas, dependendo da direção de propagação da trinca e da clivagem da ferrita. A figura 4.19 apresenta o mecanismo proposto por Inoue et al. e Kamiya et al. [32, 59]. 


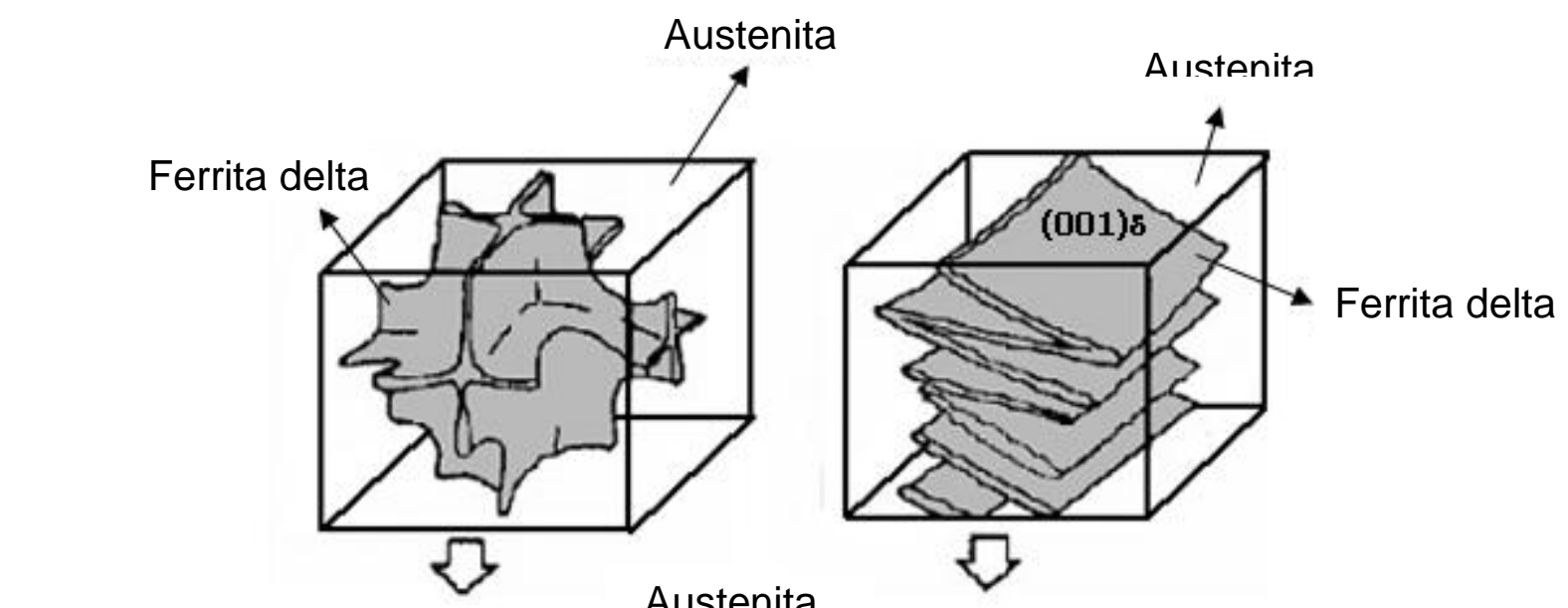

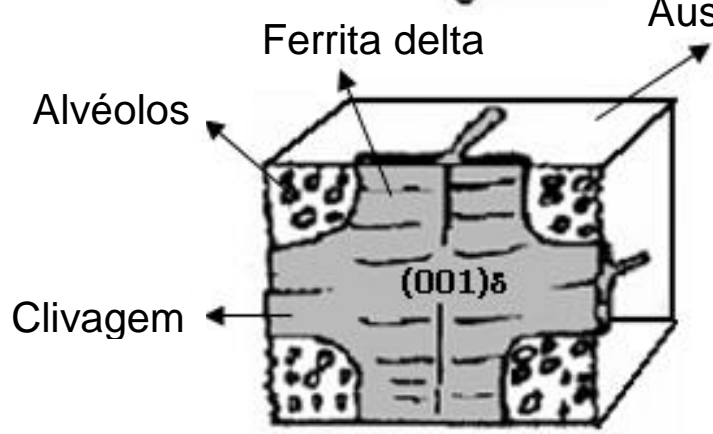

(a)

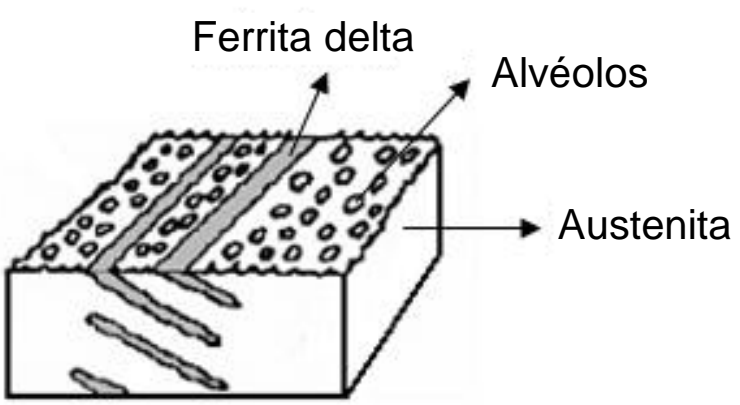

(b)

Figura 4.19: Mecanismo de fratura para ferrita vermicular (a) e acicular (b) a temperatura baixa ou criogênica: Ocorre nucleação e crescimento de alvéolos em inclusões na austenita. A ferrita vermicular cliva, enquanto a ferrrita acicular não. [32]

De acordo com o mecanismo proposto por Inoue [32], no caso da ferrita vermicular ocorrem nucleação e crescimento de alvéolos em inclusões na austenita, e clivagem na ferrita nos planos $\{100\}$. No caso da ferrita acicular, ocorrem apenas nucleação e crescimento de alvéolos sem clivagem de ferrita. Este comportamento é responsável por uma maior resistência mecânica da microestrutura quando composta principalmente por ferrita acicular na matriz austenítica.

Os corpos de prova $1(\mathrm{CA} / \mathrm{N}), 2(\mathrm{CC} / \mathrm{N})$ e $4(\mathrm{CA} / \mathrm{L})$ apresentam a mesma expansão lateral média, o corpo de prova $3(\mathrm{CC} / \mathrm{L})$ teve maior expansão lateral média para a raiz.

Neste trabalho, há duas variáveis no processo de soldagem: 
1. Tipo de corrente utilizado (corrente contínua e corrente alternada);

2. Fluxo utilizado (fluxo neutro e fluxo ligado).

A fim de se verificar a influência do fluxo nos resultados dos ensaios Charpy, foram realizadas as seguintes comparações estatísticas a um nível de significância de $1 \%$ a partir dos resultados da tabela 4.16 :

- Corpos de prova 2(CC/N) e $3(\mathrm{CC} / \mathrm{L})$ : Ambos foram soldados em corrente contínua, no entanto o corpo de prova 2 foi soldado com fluxo neutro e o corpo de prova 3 foi soldado com fluxo ligado;

- Corpos de prova $1(\mathrm{CA} / \mathrm{N})$ e $4(\mathrm{CA} / \mathrm{L})$ : Ambos foram soldados em corrente alternada, no entanto o corpo de prova 1 foi soldado com fluxo neutro e o corpo de prova 4 foi soldado com fluxo ligado.

Na tabela 4.17 estão os resultados das comparações descritas acima.

Tabela 4.17: Comparação estatística a um nível de significância de $1 \%$ entre as energias absorvidas e expansões laterais médias entre as soldas realizadas com correntes iguais. Desta forma, observa-se a influência do fluxo sobre os resultados dos ensaios Charpy.

\begin{tabular}{|c|c|c|c|}
\hline \multirow{2}{*}{\multicolumn{2}{|c|}{ Corpos de prova $\left.{ }^{*}\right)$}} & \multicolumn{2}{c|}{$\begin{array}{c}\text { Iguais para nível de significância } \\
\text { de1\%? }\end{array}$} \\
\cline { 3 - 4 } \multicolumn{2}{|c|}{} & $\begin{array}{c}\text { Energia } \\
\text { absorvida }\end{array}$ & $\begin{array}{c}\text { Expansão } \\
\text { lateral }\end{array}$ \\
\hline \multirow{2}{*}{$\begin{array}{c}\text { Corrente } \\
\text { contínua }\end{array}$} & $2(\mathrm{~N}) \times 3(\mathrm{~L})$ (face) & Diferentes & Diferentes \\
\cline { 2 - 4 } & $2(\mathrm{~N}) \times 3(\mathrm{~L})$ (raiz) & Diferentes & Iguais \\
\hline \multirow{2}{*}{$\begin{array}{c}\text { Corrente } \\
\text { alternada }\end{array}$} & $1(\mathrm{~N}) \times 4(\mathrm{~L})$ (face) & Diferentes & Iguais \\
\cline { 2 - 4 } & $1(\mathrm{~N}) \times 4(\mathrm{~L})($ raiz) & lguais & Iguais \\
\hline
\end{tabular}

$\left.{ }^{*}\right)$ O número indica o número do corpo-de-prova e a letra indica o tipo de fluxo.

Com exceção das médias entre as soldas de raiz dos corpos de prova $1(\mathrm{CA} / \mathrm{N})$ e 4 (CA/L), em que os valores podem ser considerados estatisticamente iguais ( $1 \%$ de significância), o tipo de fluxo apresentou grande influência nas energias absorvidas médias, pois para as outras soldas as médias verificadas podem ser consideradas 
diferentes a todos os níveis de significância verificados. Conclui-se que em geral o fluxo neutro é mais indicado que o fluxo ligado para as condições em que os ensaios foram realizados.

As expansões laterais não sofreram influência devido ao fluxo utilizado para um mesmo tipo de corrente, com exceção do cordão de face em corrente contínua, em que o fluxo neutro levou a uma maior ductilidade do material.

A fim de se verificar a influência do tipo de corrente de soldagem nos resultados dos ensaios Charpy, foram realizadas as seguintes comparações estatísticas a um nível de significância de 1\%:

- Corpos de prova $1(\mathrm{CA} / \mathrm{N})$ e $2(\mathrm{CC} / \mathrm{N})$ : Ambos foram soldados com fluxo neutro, no entanto o corpo de prova $1(\mathrm{CA} / \mathrm{N})$ foi soldado em corrente alternada e o corpo de prova $2(\mathrm{CC} / \mathrm{N})$ foi soldado em corrente contínua;

- Corpos de prova $3(\mathrm{CC} / \mathrm{L})$ e 4 (CA/L): Ambos foram soldados com fluxo ligado, no entanto o corpo de prova 3 (CC/L) foi soldado em corrente contínua e o corpo de prova 4 (CA/L) foi soldado em corrente alternada.

Na tabela 4.18 estão os resultados das comparações descritas acima.

Tabela 4.18: Comparação estatística a um nível de significância de $1 \%$ entre as energias absorvidas e expansões laterais médias entre as soldas realizadas com correntes iguais, de maneira a verificar a influência do tipo de corrente utilizado na soldagem sobre os resultados dos ensaios Charpy.

\begin{tabular}{|c|c|c|c|}
\hline \multicolumn{2}{|c|}{ Corpos de prova $\left(^{*}\right)$} & \multicolumn{2}{c|}{$\begin{array}{c}\text { Iguais para nível de significância de } \\
1 \% ?\end{array}$} \\
\cline { 3 - 4 } & Energia absorvida & $\begin{array}{c}\text { Expansão } \\
\text { lateral }\end{array}$ \\
\hline \multirow{2}{*}{$\begin{array}{c}\text { Fluxo } \\
\text { neutro }\end{array}$} & $1(\mathrm{CA}) \times 2(\mathrm{CCPR})($ face) & Diferentes & Iguais \\
\cline { 2 - 4 } & $1(\mathrm{CA}) \times 2(\mathrm{CCPR})($ raiz) & Diferentes & Iguais \\
\hline \multirow{2}{*}{$\begin{array}{c}\text { Fluxo } \\
\text { ligado }\end{array}$} & $3(\mathrm{CC}) \times 4(\mathrm{CA})($ face) & Diferentes & Diferentes \\
\cline { 2 - 4 } & $3(\mathrm{CC}) \times 4(\mathrm{CA})($ raiz) & Diferentes & Iguais \\
\hline
\end{tabular}

$\left(^{*}\right)$ O número indica o número do corpo-de-prova e as letras indicam o tipo de corrente. 
O tipo de corrente apresentou grande influência nas energias absorvidas médias, que foram diferentes para ambos os fluxos testados. Conclui-se que nas condições dos ensaios, a soldagem em corrente alternada produziu corpos-de-prova com maior capacidade de absorver energia antes de se fraturar.

Em relação às expansões laterais, o tipo de corrente utilizada acarretou diferenças apenas na soldagem de face com fluxo ligado, em que o a corrente alternada e onda quadrada levou a maior ductilidade do material.

Ao se verificar se os resultados obtidos no ensaio de impacto Charpy $V$ indicavam alguma relação entre as energias absorvidas e as expansões laterais sofridas pelos corpos de prova, não se chegou a nenhuma conclusão, conforme o anexo B.

\subsubsection{Ensaio de impacto (Charpy V) - Micrografias}

Foram fotografadas no microscópio óptico a propagação das trincas nos corpos de prova de 1 a 4 , ilustradas nas figuras 4002E20 e 4.21 .
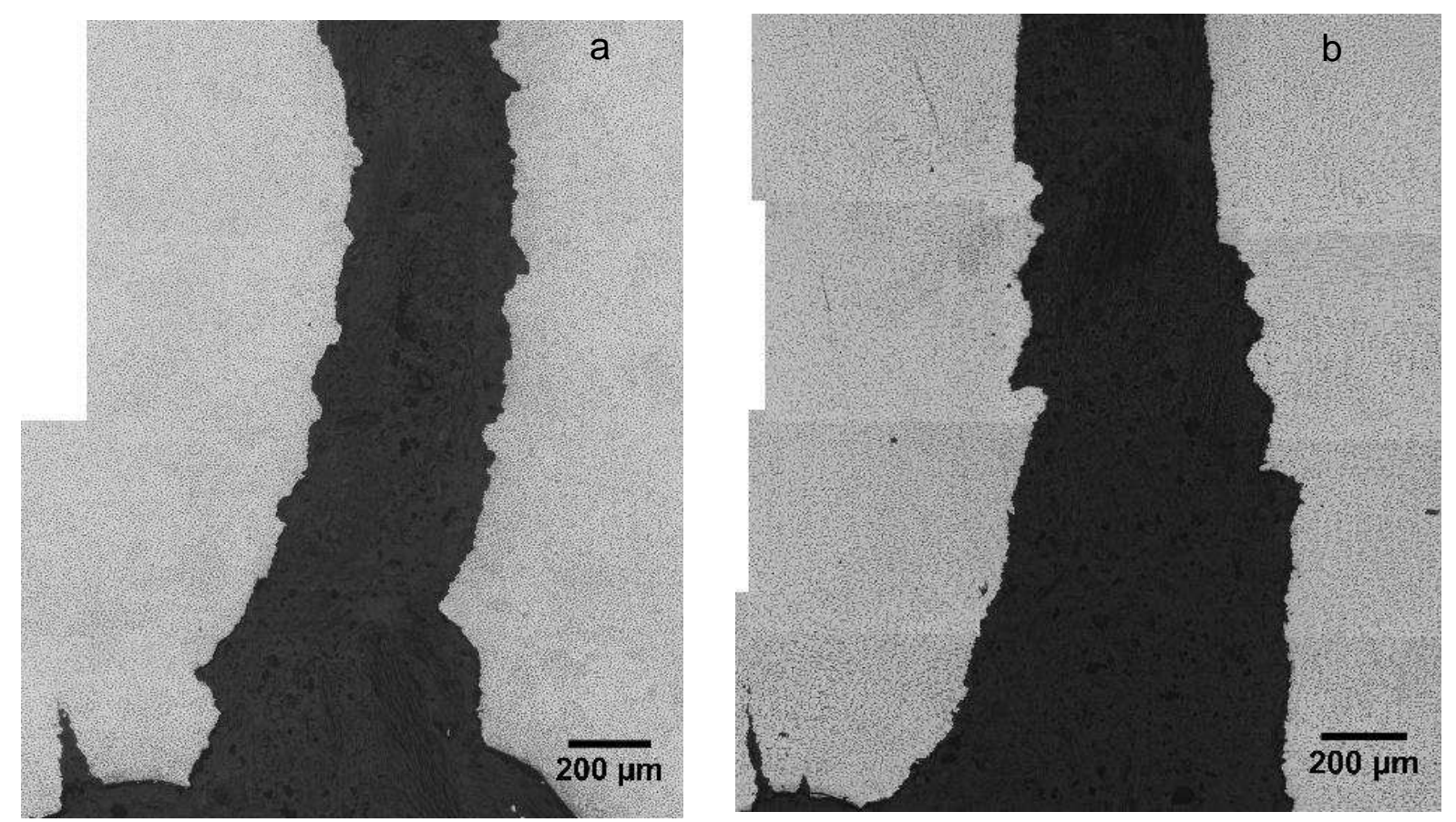

Figura 4.20: Propagação da trinca nos corpos de prova $1(\mathrm{CA} / \mathrm{N})$ (a) e 2 (CC/N) (b), soldados com fluxo neutro. Observa-se formação de trincas secundárias. Microscópio óptico. 

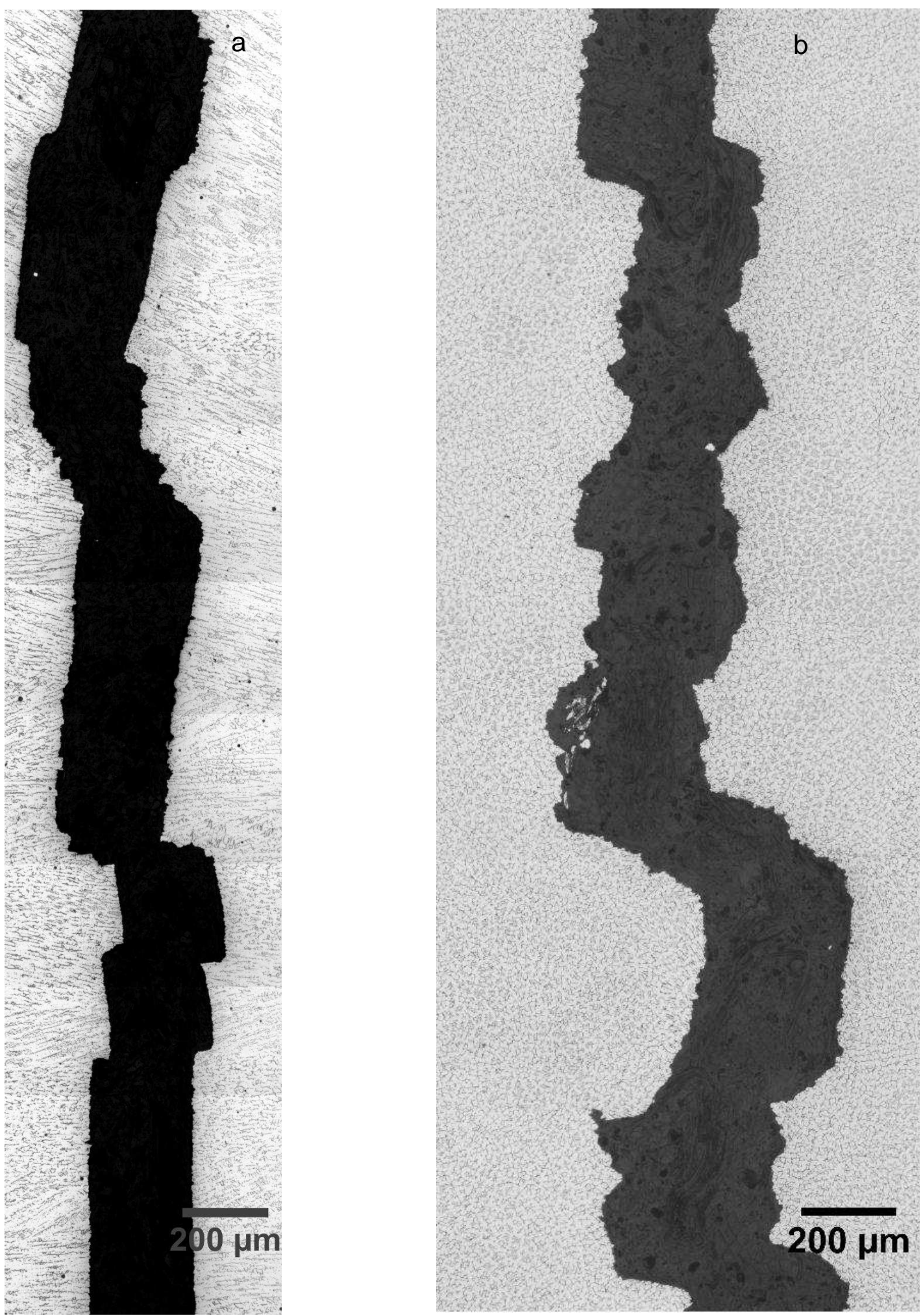

Figura 4.21: Propagação da trinca nos corpos de prova $3(\mathrm{CC} / \mathrm{L})$ (a) e $4(\mathrm{CC} / \mathrm{N})(\mathrm{b})$, soldados com fluxo ligado. No corpo de prova $3(\mathrm{CC} / \mathrm{L})$ a propagação da trinca é mais linear que nos demais corpos de prova. Para o corpo de prova $4(\mathrm{CC} / \mathrm{N})$, observam-se trincas secundárias. Microscópio óptico. 
Conforme se observa nas figuras 4.20 e 4.21 , surgiram trincas secundárias nos corpos de prova $1(\mathrm{CA} / \mathrm{N}), 2(\mathrm{CC} / \mathrm{N})$ e $4(\mathrm{CA} / \mathrm{L})$, permitindo desta forma que o material absorva maior energia antes de se romper. Também é possível notar que nos corpos de prova $1(\mathrm{CA} / \mathrm{N}), 2(\mathrm{CC} / \mathrm{N})$ e $4(\mathrm{CA} / \mathrm{L})$ a trinca se propaga com formato arredondado, enquanto a propagação da trinca no corpo de prova 3 (CC/L) apresentou um formato mais linear. Os desvios na direção da trinca observados nos corpos de prova $1(\mathrm{CA} / \mathrm{N}), 2(\mathrm{CC} / \mathrm{N})$ e $4(\mathrm{CA} / \mathrm{L})$ requerem mais energia para a propagação da mesma.

A figura 4.22 destaca uma região da trinca no corpo de prova $3(\mathrm{CC} / \mathrm{L})$. Nela se observa ferrita vermicular, conforme previsto pela relação $(\mathrm{Cr} / \mathrm{Ni})_{\text {eq }}$. Esta microestrutura apresenta um padrão orientado, o que facilita a propagação da trinca. Ao centro da dendrita de austenita há um alto teor de inclusões, as quais levam à fratura por nucleação e crescimento de alvéolos. No detalhe (b) da figura 4.22, é visível que este mecanismo atua juntamente com a clivagem da ferrita, uma vez que a propagação da trinca tende a seguir o padrão de orientação da ferrita delta. 


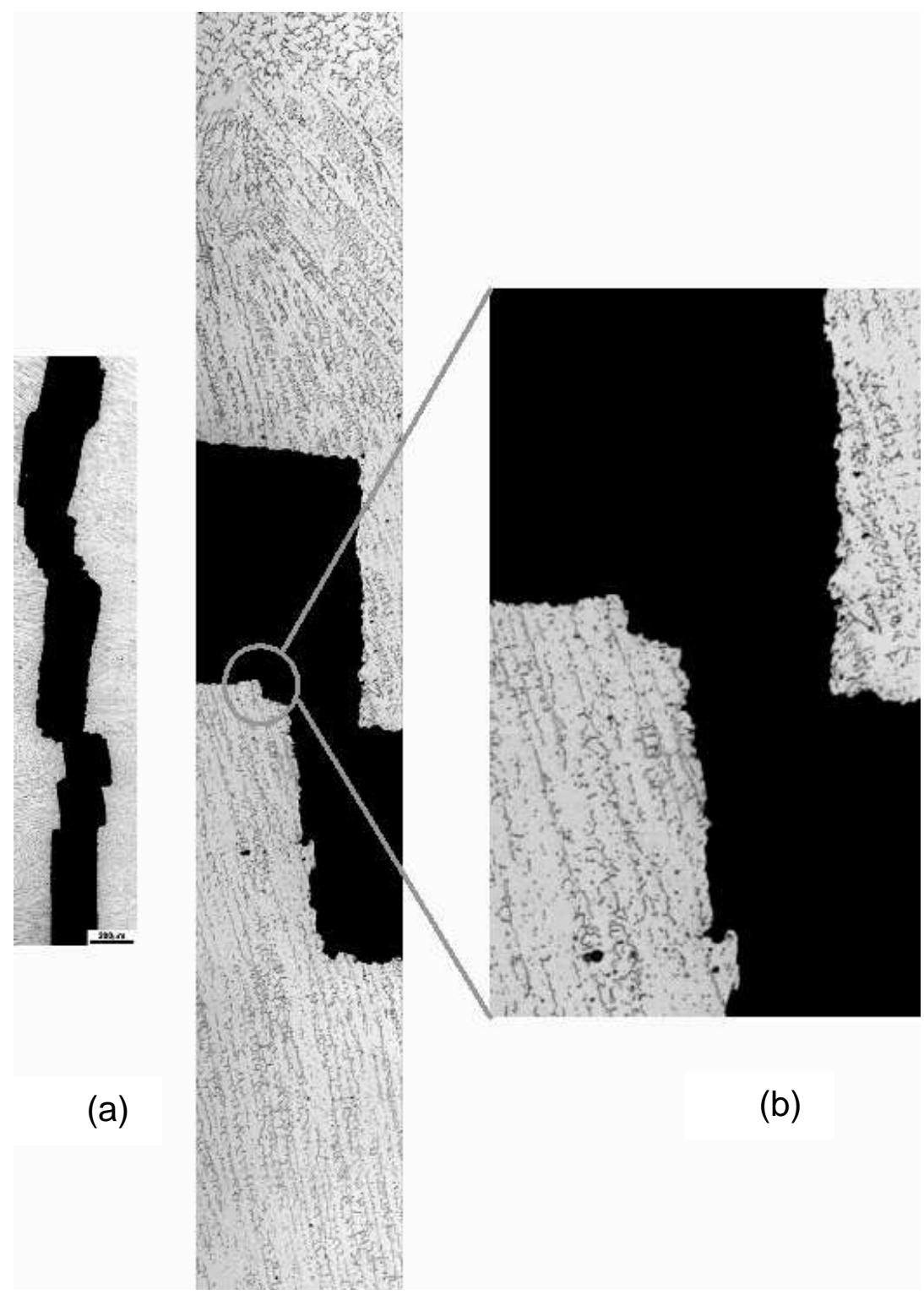

Figura 4.22: Propagação de trinca no corpo de prova 3 (CC/L), em baixo aumento (a) e alto aumento (b). Microscópio óptico.

Conforme se nota novamente na figura 4.23 , as fraturas acompanham a morfologia da ferrita e de inclusões, de acordo com o esperado para ensaios de impacto a baixas temperaturas. 


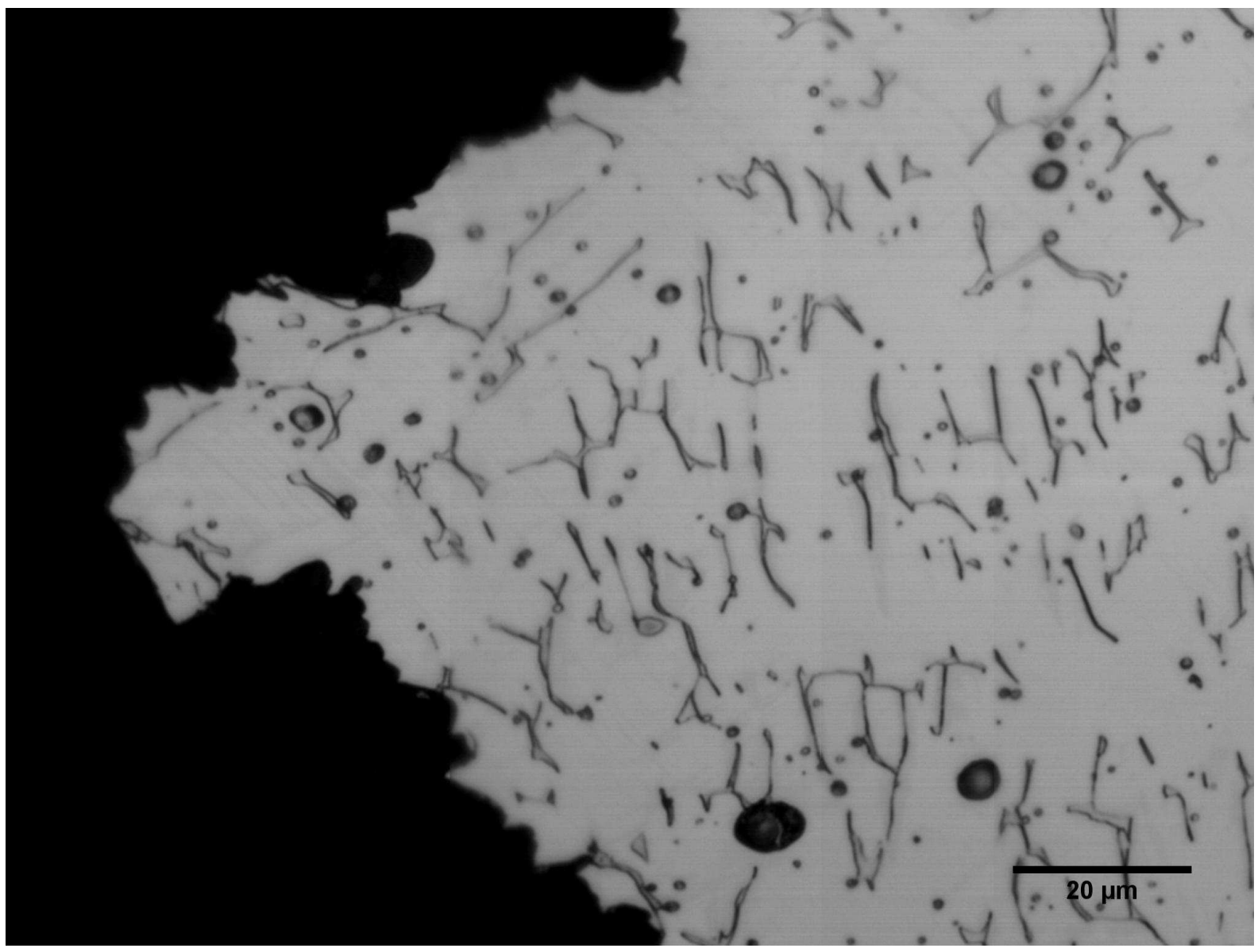

Figura 4.23: Fratura acompanha a morfologia da ferrita e de inclusões. Microscópio óptico.

\subsubsection{Ensaio de impacto (Charpy V) - microfractografias}

A figura 4.24 e 4.25 apresentam as superfícies de fratura dos corpos de prova 1 $(C A / N)$ e $2(C C / N)$, respectivamente. Observa-se que as superfícies de fratura são relativamente irregulares, o que requer maior energia para propagação da trinca. $O$ mesmo foi observado para o corpo de prova 4 (CA/L). 


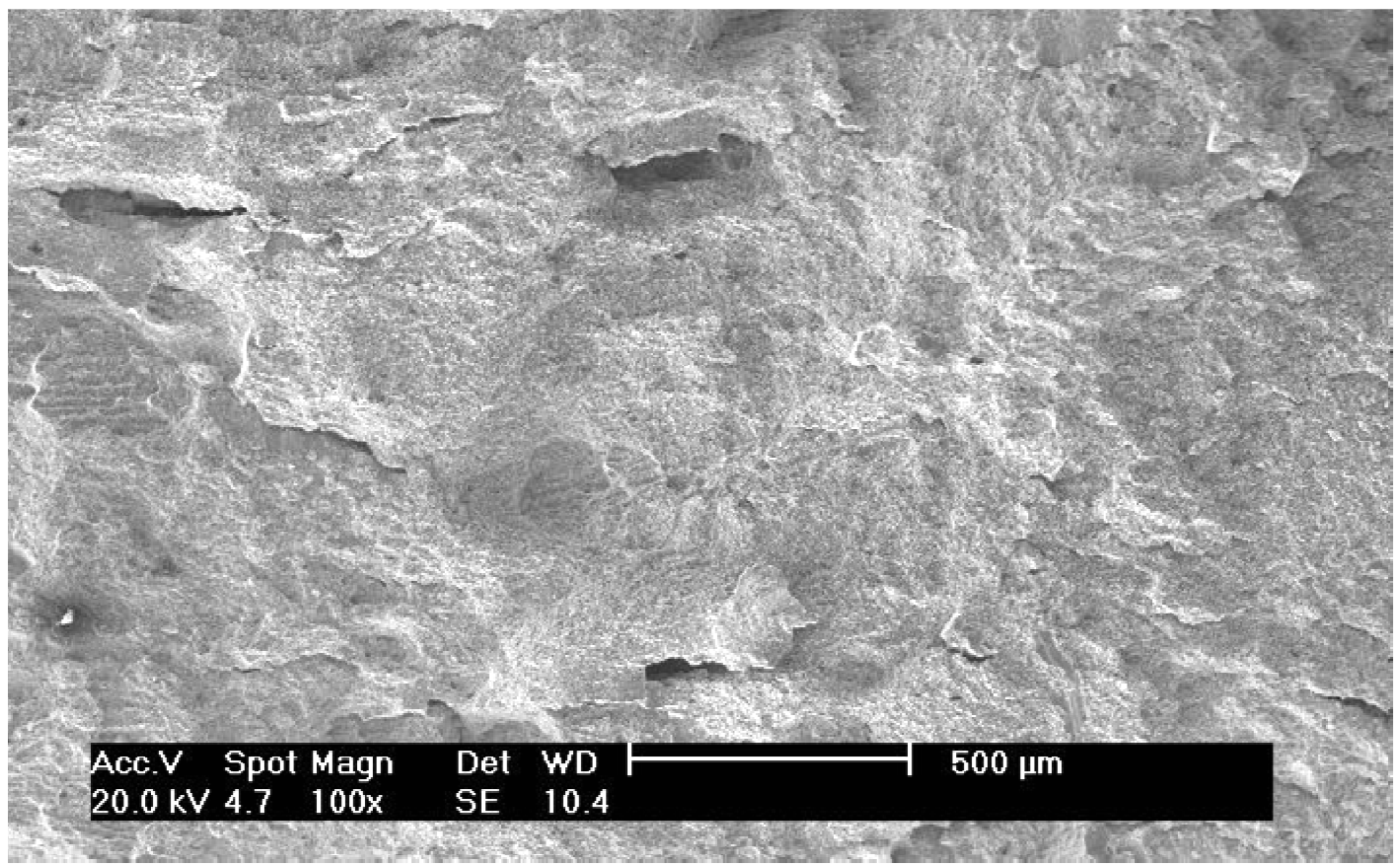

Figura 4.24: Superfície de fratura do corpo de prova $1(\mathrm{CA} / \mathrm{N})$. Observa-se uma superfície irregular, que indica mudanças de direção durante a propagação da trinca, necessitando maior energia. Microscópio eletrônico de varredura, elétrons secundários.

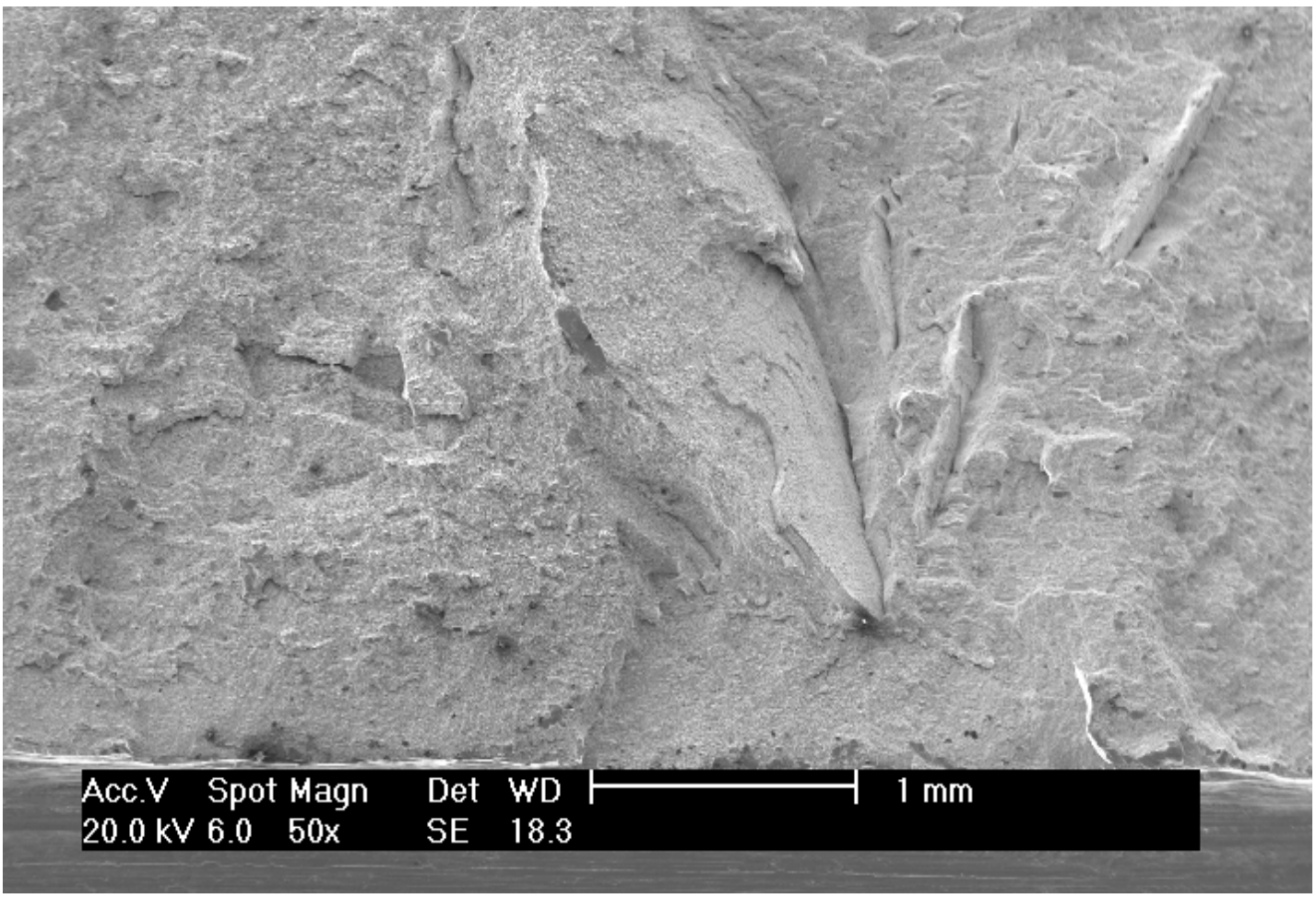

Figura 4.25: Superfície de fratura do corpo de prova 2 (CC/N). A superfície de fratura é irregular, novamente indicando mudanças de direção durante a propagação da trinca que requerem maior energia para o material fraturar. Microscópio eletrônico de varredura, elétrons secundários. 
Na figura 4.26, observa-se uma superfície de fratura do corpo de prova $3(\mathrm{CC} / \mathrm{L})$, o qual apresentou os valores mais baixos de energias absorvidas. Verifica-se grandes regiões planas na superfície de fratura, o que indica menor absorção de energia durante a propagação da trinca. A figura 4.27 também apresenta uma superfície de fratura do corpo de prova 3 (CC/L), onde se observa superfícies de fratura plana, embora predomine os alvéolos. Isto vai de acordo com o observado anteriormente na figura 4.21 (a).

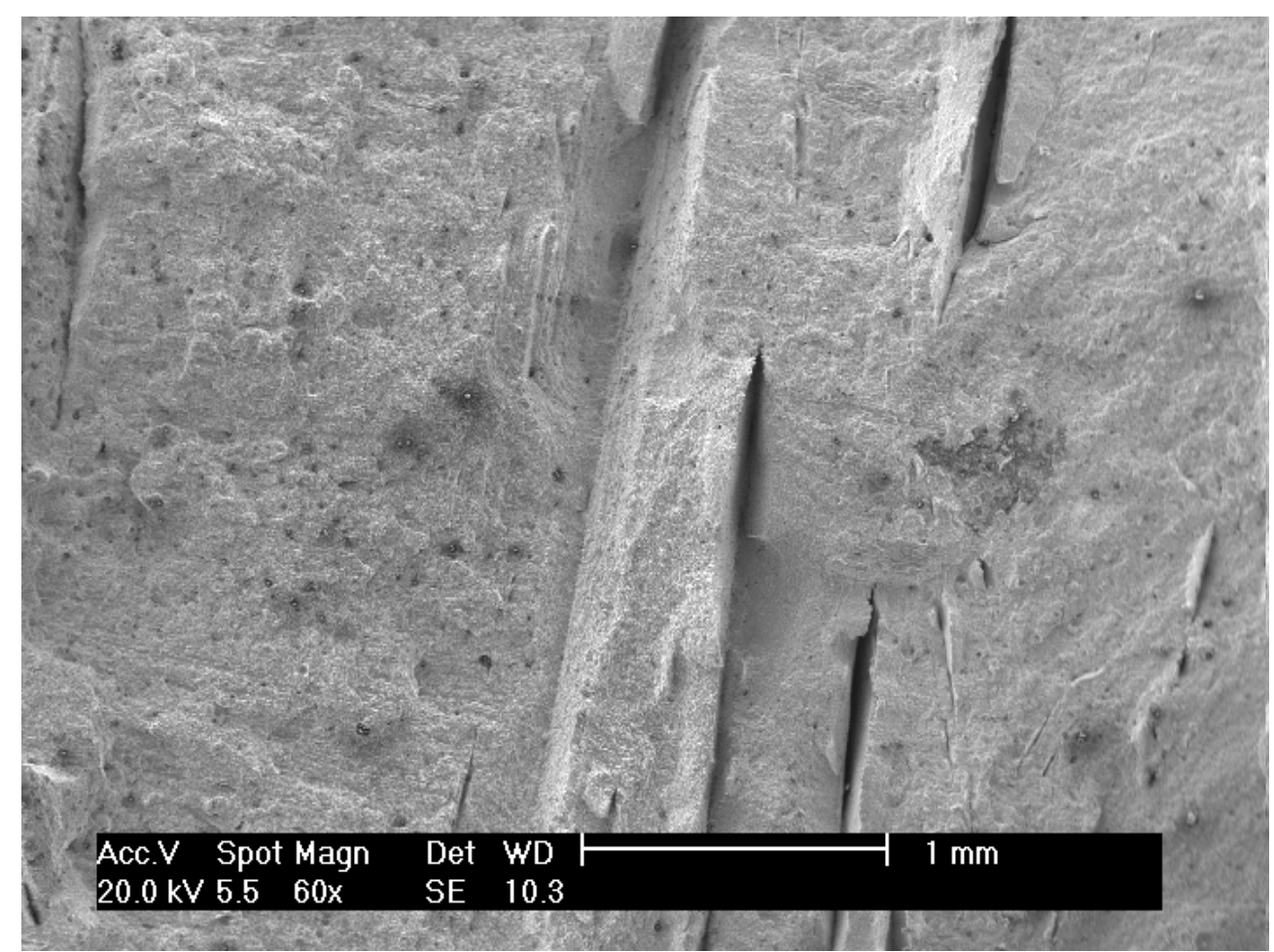

Figura 4.26: Superfície de fratura do corpo de prova 3 (CC/L) (raiz). A superfície apresenta grandes regiões planas, indicando menor quantidade de mudanças de direção e, consequentemente, absorvendo menos energia durante a propagação da trinca. Microscópio eletrônico de varredura, elétrons secundários. 


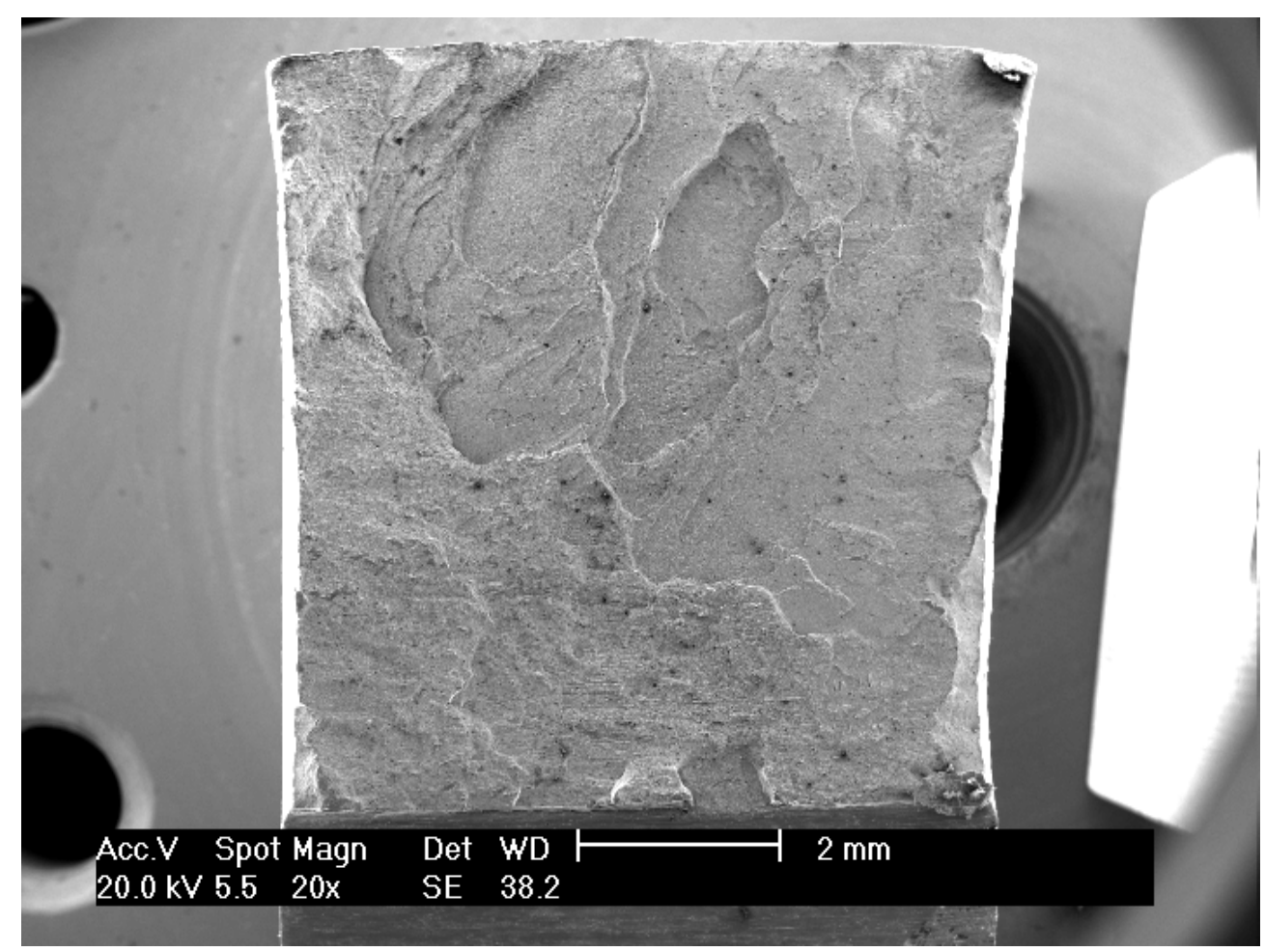

Figura 4.27: Superfície de fratura do corpo de prova 3 (CC/L) (face). A superfície fraturada apresenta grandes regiões planas. Microscópio eletrônico de varredura, elétrons secundários. 


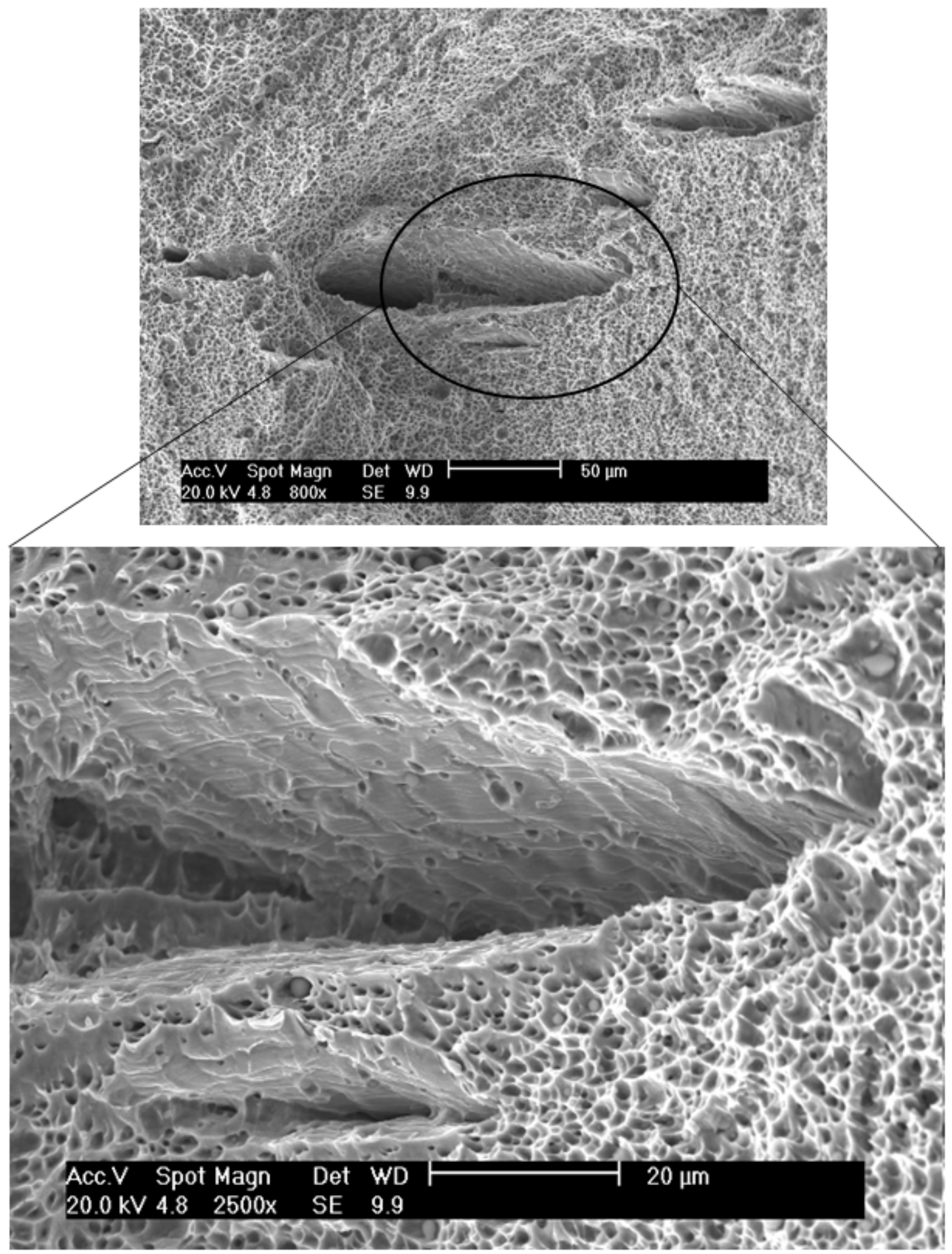

Figura 4.28: Superfície de fratura do corpo de prova $2(\mathrm{CC} / \mathrm{N})$. As regiões austeníticas possuem alvéolos dúcteis em sua microestrutura, e regiões que ferríticas apresentam fratura por clivagem em um plano distinto. Microscópio eletrônico de varredura, elétrons secundários. 
$\mathrm{Na}$ figura 4.28 são visíveis fraturas na ferrita (clivagem) e na austenita (alvéolos) no corpo de prova $2(\mathrm{CC} / \mathrm{N})$. Observa-se que há predominância de alvéolos, indicando que ocorreu fratura dúctil no material.
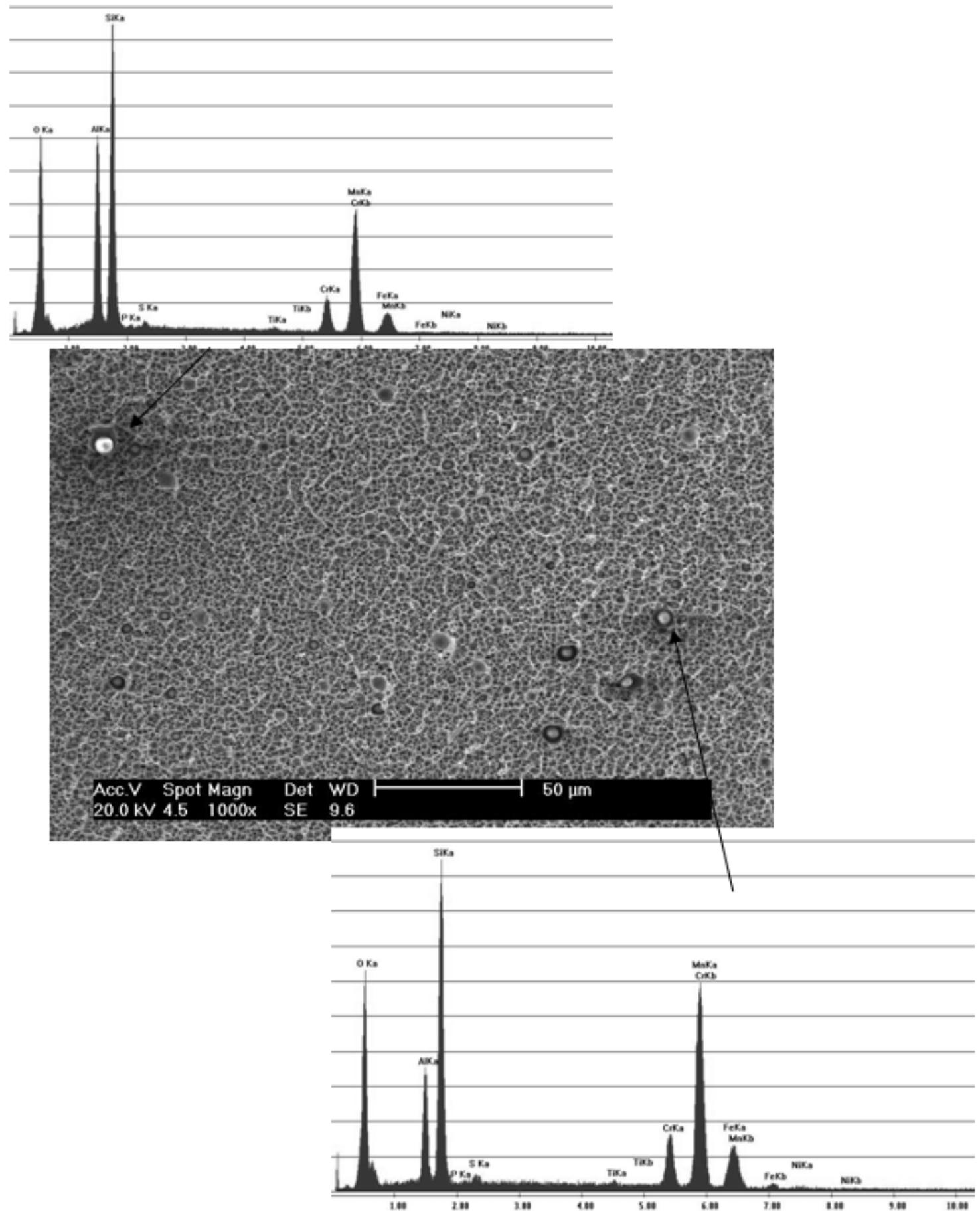

Figura 4.29: Inclusões no corpo de prova 3 (CC/L). Microscópio eletrônico de varredura. 
$\mathrm{Na}$ figura 4.29 é visível que o corpo de prova 3 (CC/L) apresenta grande quantidade de inclusões, o que favorece a nucleação das trincas.

Os resultados quantitativos da análise por energia de dispersão da inclusão branca e da inclusão cinza na figura 4.29 estão na tabela 4.19 .

Tabela 4.19: Resultados da análise por EDS de inclusões no corpo de prova 3 (CC/L).

\begin{tabular}{|c|c|c|}
\hline \multirow{2}{*}{ Elemento } & \multicolumn{2}{|c|}{ Teor (\%) } \\
\cline { 2 - 3 } & $\begin{array}{c}\text { Inclusão } \\
\text { branca }\end{array}$ & $\begin{array}{c}\text { Inclusão } \\
\text { cinza }\end{array}$ \\
\hline $\mathrm{O}$ & 44,54 & 41,28 \\
\hline $\mathrm{Al}$ & 14,45 & 9,15 \\
\hline $\mathrm{Si}$ & 24,26 & 24,12 \\
\hline $\mathrm{P}$ & 0,07 & - \\
\hline $\mathrm{S}$ & 0,47 & 0,67 \\
\hline $\mathrm{Ti}$ & 0,33 & 0,40 \\
\hline $\mathrm{Mn}$ & 15,88 & 24,38 \\
\hline
\end{tabular}

Em ambas as inclusões analisadas foram encontrados elevados teores de oxigênio, silício e alumínio.

A fim de verificar se o corpo de prova $3(\mathrm{CC} / \mathrm{L})$ possuía maior quantidade de inclusões que os demais, mediu-se que os alvéolos para os corpos de prova de $1 \mathrm{a}$ 4 possuem os raios médios discriminados na tabela 4.20 através de 10 medições de quantos alvéolos havia em uma distância de 25 micrometros. 
Tabela 4.20: Raios médios dos alvéolos para os corpos de prova de 1 a 4 .

\begin{tabular}{|c|c|}
\hline Corpo de prova & Raio Médio \\
\hline $1(\mathrm{CA} / \mathrm{N})$ & $1,74 \pm 0,25$ \\
\hline $2(\mathrm{CC} / \mathrm{N})$ & $1,86 \pm 0,40$ \\
\hline $3(\mathrm{CC} / \mathrm{L})$ & $1,62 \pm 0,23$ \\
\hline $4(\mathrm{CA} / \mathrm{L})$ & $1,74 \pm 0,20$ \\
\hline
\end{tabular}

Estatisticamente, os raios médios dos alvéolos são iguais. No entanto, se desconsiderar os desvios padrão, tem-se que o raio médio dos alvéolos no corpo de prova $3(C C / L)$ é menor que os demais, ou seja, ele possui maior quantidade de inclusões por volume que os corpos de prova $1(\mathrm{CA} / \mathrm{N}), 2(\mathrm{CC} / \mathrm{N})$ e $4(\mathrm{CA} / \mathrm{L})$. Este resultado pode ser confirmado pelo teor de oxigênio, que é maior na condição $3(\mathrm{CC} / \mathrm{L})$. 


\section{Conclusões}

Com base nos materiais, processos de soldagem e resultados, pode-se concluir que:

1. As soldagens realizadas pelos quatro parâmetros de soldagem distintos foram qualificadas, sendo que a soldagem realizada em corrente alternada de onda quadrada balanceada utilizando-se fluxo neutro apresentou a maior tenacidade à baixa temperatura.

2. Em todos os corpos de prova, os teores de cromo e níquel aumentaram em relação ao metal de base. A soldagem em corrente alternada de onda quadrada apresentou o menor teor de oxigênio que a soldagem em CCPR $(+)$;

3. A relação $\mathrm{Cr}_{e q} / \mathrm{Ni}_{\text {eq }}$ é maior para corrente alternada de onda quadrada que para CCPR (+);

4. À temperatura ambiente, todas as amostras apresentaram resistência à tração acima da mínima requerida por norma, porém a amostra soldada em corrente alternada e fluxo ligado apresentou o menor limite de resistência à tração, cujo mecanismo de fratura é controlado pela nucleação, crescimento e coalescência de alvéolos, que nucleiam em inclusões de óxidos;

5. Os corpos de prova soldados em corrente alternada e fluxo neutro absorveram mais energia no ensaio de impacto, seguidos por corrente contínua e fluxo neutro, corrente alternada e fluxo ligado e corrente contínua e fluxo ligado. A fratura pode ocorrer por um mecanismo de fratura dúctil (nucleação e crescimento de alvéolos na austenita) ou frágil (clivagem de ferrita delta e caminho médio da trinca). O corpo de prova soldado em corrente contínua e fluxo ligado apresentou o maior teor de oxigênio e ferrita vermicular, que por ser mais contínua e alinhada, leva a um caminho médio de trinca maior;

6. Nas amostras com predominância de ferrita acicular, observou-se trincas secundárias. Neste caso, a clivagem de ferrita ocorre em um plano de 
orientação diferente do plano de propagação da trinca principal, aumentando a energia absorvida pelo corpo de prova. 


\section{Referências bibliográficas}

1. LEBRUN, P. An Introduction to Cryogenics. European Organization for Nuclear Research, CERN/AT 2007-1.

2. LEBRUN, P. Cryogenics, Key to Advanced Science and Technology. Bulletin of the IIR, no $2003-6$.

3. ROE, G. J.; BRAMFITT, B. L. Notch toughness of steels. In: ASM Metals Handbook, 1990, v. 1, p. 737-742.

4. HERTZBERG, R. W. Deformation and fracture mechanics of engineering materials. John Wiley \& Sons Inc, fourth ed, 1996, p. 375-378.

5. DONATO, G.; CRAVERO, S.; RUGGIERI, C. Avaliação experimental dos parâmetros de tenacidade CTOD e integral $J$ em espécimes de flexão $S E(B)$ utilizando o método eta. Congresso da. ABM, 2006, p. 61. Anual.

6. SILVA, R. V. Avaliação da tenacidade à fratura de soldas de alta resistência e baixa liga pelo método da integral-J. Universidade de São Paulo Escola de Engenharia de São Carlos, Departamento de Materiais, p. 12-35, 1998.

7. CALLISTER, W. D. J. Materials science and engineering. lowa, John Wiley \& Sons. $7^{\text {th }}$ ed, p. 178-188, 2007.

8. GRIFFITH, A. A. The phenomena of rupture and flow in solids. Philosophical Transactions of the Royal Society of London, n. 221, p. 163-198, 1921.

9. ZHU, X. K. J-integral resistance curve testing and evaluation. Journal of Zhejiang University Science, v. 10, n. 11, p. 1541-1560, 2009.

10. WELLS, A. A. Unstable Crack Propagation in Metals: Cleavage and Fast Fracture. Cranfield Crack Propagation Symposium, 1961, v. 1, p. 210. 
11. SCHÖN, C. G. Mecânica dos Materiais: Apostila redigida para uso nos cursos "PMT2405 - Mecânica dos Materiais" e "PMT5860 - Teoria da plasticidade e da fratura dos materiais". 4⿳亠丷a ed., 2009, p. 96-97, 147-161.

12. ROSSOLL, A.; BERDIN, C.; PRIOUL, C. Determination of the Fracture Toughness of a Low Alloy Steel by the Instrumented Charpy Impact Test. International Journal of Fracture, n. 115, p. 205-226, 2002.

13. HERTZBERG, R. W. Deformation and Fracture Mechanics of Engineering Materials. John Wiley \& Sons, $4^{a}$ ed., 1996, p. 342.

14. ESHELBY, J. D. The force of an elastic singularity. Philosophical Transactions of the Royal Society of London. Series A, Mathematical and Physical Sciences, v. 244, n. 877, p. 87-111, 1951.

15. CHEREPANOV, G. P. The propagation of cracks in a continuous medium, Journal of Applied Mathematics and Mechanics, v. 31, n. 3, p. 503-512, 1967.

16. RICE, J. R. A Path Independent Integral and the Approximate Analysis of Strain Concentration by Notches and Cracks, Journal of Applied Mechanics, v. 35, p. 379-386, 1968.

17. TOBLER, R. L., SIEWERT T. A., MCHENRY H. I. Strength-toughness relationship for austenitic stainless steel welds at $4 \mathrm{~K}$. Fracture and Deformation Division, National Bureau of Standards, USA, 1986.

18. BAKER, H. Introduction to Alloy Phase Diagrams. In: ASM Metals Handbook, 1991, v. 3, p. 1.1-1.5.

19. PADILHA, A. F.; GUEDES, L. C. Aços inoxidáveis austeníticos: Microestrutura e propriedades. 1 ed. São Paulo: Hemus Editora, 1994, p. 17-25. 
20. RAYNOR, G. V., RIVLIN, V. G. Phase equilibria in iron ternary alloys. The Institute of Metals, n. 4, paginação não indicada, 1988.

21. WASHKO, S. D., AGGEN, G. Wrought stainless steels. In: ASM Metals Handbook, 1990, v. 1, p. 841-842.

22. SUUTALA, N.; TAKALO, T.; MOISIO T. Single-phase ferritic solidification mode in austenitic-ferritic stainless steel welds. Metallurgical Transactions, v. 10A, n. 8, p. 1183-1190, 1979.

23. MODENESI, P. J. Soldabilidade de algumas ligas metálicas. Disponível em: <http://www.demet.ufmg.br/grad/disciplinas/emt019/metais soldab.pdf>. Acesso em $01 / 10 / 2008$.

24. BROOKS, J. A.; LIPPOLD, J. C. Selection of Wrought Austenitic Stainless Steels. In: ASM Metals Handbook, 1992, v. 6, p.456-457.

25. $\mathrm{CHI}, \mathrm{K}$. et al. Single sided single pass submerged arc welding of austenitic stainless steel. Materials Science and Technology, v. 23, n. 9, p. 10391048, 2007.

26. MICHLER, T. Toughness and hydrogen compatibility of austenitic stainless steel welds at cryogenic temperatures. International Journal of Hydrogen Energy, n. 32, p. 4081-4088, 2007.

27. TAKALO, T.; SUUTALA, N.; MOISIO, T. Austenitic solidification mode in austenitic stainless steel welds. Metallurgical Transactions, v. 10A, n. 8, p. 1173$1181,1979$.

28. SUUTALA, N.; TAKALO, T.; MOISIO T. Ferritic-austenitic solidification mode in austenitic stainless steel welds. Metallurgical Transactions. v. 11A, n. 5, p. 717-725, 1980.

29. FU, J. W.; YANG, Y. S.; GUO, J. J. Formation of a blocky ferrite in Fe-Cr$\mathrm{Ni}$ alloy during directional solidification. Journal of Crystal Growth. n. 311, p. 3661-3666, 2009. 
30. LIPPOLD, J. C.; SAVAGE, W. F. Solidification of austenitic stainless steel weldments: part II - The effect of alloy composition on ferrite morphology. Weld. J.. v. 59, n. 2, p. $48 \mathrm{~s}-58 \mathrm{~s}, 1980$.

31. IBRAHIM, O. H.; IBRAHIM, I. S.; KHALIFA, T. A. F. Impact behavior of different stainless steel weldments at low temperatures. Engineering failure analysis, v. 17, p. 1069-1076, 2010.

32. INOUE, $\mathrm{H}$. et al. Formation mechanism of different ferrite morphologies and effect of ferrite morphology on cryogenic impact toughness and pitting corrosion resistance in austenitic stainless steel weld metals. Quarterly Journal of the Japan Welding Society, v. 19, n. 1, p. 100-113, 2001.

33. KAMIYA, O.; KUMAGAI, K. Effect of microstructure on impact fracture behaviour of SUS304L SAW joint at low temperature. Journal of materials science, n. 25, p. 2017-2024, 1990.

34. BIGGS, W. D., PRATT, P. L. The deformation and fracture of alpha-iron at low temperatures. Acta Metallurgica, vol. 6, p. 694-703, 1958.

35. LIU, S. C. et al. A Study on Fractography in the Low-Temperature Brittle Fracture of an $18 \mathrm{Cr}-18 \mathrm{Mn}-\mathbf{0 . 7 N}$ Austenitic Steel. Metallurgical and Materials Transactions, vol. 29A, p. 791-798, 1998.

36. BAEK, J. H. et al. Effect of Temperature on the Charpy Impact and CTOD Values of Type 304 Stainless Steel Pipeline for LNG Transmission. KSME International Journal. V. 16, n. 8, p. 1064-1071, 2002.

37. LANCASTER, J. F. Metallurgy of Welding. Chapman \& Hall, fifth ed, 1993, p. 259-274.

38. EKSTRÖM, U.; OLSSON, K. The influence of ferrite and oxygen contents on weld metal mechanical properties of submerged-arc welded stainless steels. Weld Pool Chemistry and Metallurgy, Int. Conf, London, UK, April 15-17, p. 323-334. 
39. EAGAR, T. W. Sources of weld metal oxygen contamination during submerged arc welding. New Orleans, AWS $59^{\text {th }}$ annual meeting. April 3-7, 1978.

40. GRONG, O. Metallurgical Modelling of Welding. The Institute of Materials, second edition, 1997, p. 116-120, 171-172.

41. HÄGG, F. How to achieve good impact properties at cryogenic temperatures?. AvestaPolarit Welding AB. Welding News, n. 1, p. 9-10, 2004.

42. NAGE, D. D.; RAJA, V. S.; RAMAN, R. Effect of nitrogen addition on the microstructure and mechanical behavior of $317 \mathrm{~L}$ and $904 \mathrm{~L}$ austenitic stainless steel welds. J. Mater Sci. n. 41, p. 2097-2112, 2006.

43. ENJO, T.; KIKUCHI, Y.; MOROI, H. Influence of nitrogen on the structure and low temperature impact properties of $\mathbf{3 0 4}$ type austenitic stainless steel weld metals by SMAW process. Transactions of JWRI, v. 15, n. 1, p. 77-84, 1986.

44. AMERICAN SOCIETY FOR METALS. Metals Handbook, vol. 10, Failure Analysis and Prevention. eighth edition, 1975, p.347-348.

45. SCHAEFFLER, A. L. Constitution diagram for stainless steel weld metal. Metal Progress, v.56, n. 11, p. 680-680B, 1949.

46. INDACOCHEA, J. E. et al. Chemical Reactions during Submerged Arc Welding with FeO-MnO-SiO ${ }_{2}$ Fluxes. Metallurgical Transactions B, v. 16B, p. 237245, 1985.

47. GRONG, O. et al. A Model for the Silicon-Manganese Deoxidation of Steel Weld Metals. Metallurgical Transactions A, v. 17A, p. 1797-1807, 1986.

48. BLANDER, M.; OLSON, D. L. Thermodynamic and Kinetic Factors in the Pyrochemistry of Submerged Arc Flux Welding of Iron-Based Alloys. Second International Symposium on Metallurgical Slags and Fluxes, Conference Proceedings, p. 272-277, 1984. 
49. FROST, R. H.; OLSON, D. L.; EDWARDS, G. R. The influence of electrochemical reactions on the chemistry of eletroslag welding process. IN: 'Modeling of casting and welding process II' Eng. Conf. Proceedings, Ed. J.A Dantzig and J.T. Berry, Met. Soc. AIME, p. 279-294, 1983.

50. TULIANI, S. S.; BONISZEWSKI, T.; EATON, N. F. Notch toughness of commercial submerged arc weld metal. Welding Metal Fabrication. n. 37, p. 327339, 1969.

51. BLANDER, M.; OLSON D. L. Electrochemical effects on weld pool chemistry in submerged arc and dc electroslag welding, In: International Conference on Trends in Welding Research, Tennessee, USA. Proceedings, Ohio American Society for Metals, p. 363-366, 1986.

52. WAINER, E.; BRANDI, S. D.; MELLO, F. D. H. Soldagem: processos e metalurgia. Edgard Blücher LTDA, 1를. ed., p. 133-150. 1995, p. 371-378.

53. AVERY, R. E.; PARSONS, D. Welding stainless and $9 \%$ nickel steel cryogenic vessels. Nickel development institute, p. 45-50, November, 1995.

54. Disponível em: <http://www.millerwelds.com/education/articles/articles57.html>. Acesso em 04/11/2008.

55. ZHENG, B. et al. Waveform-Controlled Tandem AC/AC SAW for High Productivity Welding of HSLA 100. Disponível em: http://files.aws.org/conferences/abstracts/2005/papers/01E.pdf. Acesso em $04 / 11 / 2008$.

56. SUUTALA, N. Effect of solidification conditions on the solidification mode in austenitic stainless steels. Metallurgical Transactions, v.14A, n. 2. p. 191197, 1983.

57. DAVID, S. A.; BABU, S. S.; VITEK, J. M. Welding: Solidification and Microstructure. Disponível em: http://www.tms.org/pubs/journals/JOM/0306/David0306.html. Acesso em 06/11/2008. 
58. ELMER, J.W.; ALLEN, S.M.; EAGAR, T.W. Microstructural development during solidification of stainless steel alloys. Metallurgical Transactions, v. 20A, n. 10, p. 2118-2131, 1989.

59. KAMIYA, O.; KUMAGAI, K.; FUTAMI, T. Effect of ferrite morphology on fracture mode of stainless steel weld metal. Welding International, v. $8, n$. 10, p. 798-803, 1994.

60. LEE, D. J. et al. The dependence of crack properties on the $\mathrm{Cr} / \mathrm{Ni}$ equivalent ratio in AISI $304 \mathrm{~L}$ austenitic stainless steel weld metals. Materials science and engineering, 513-514, p. 154-159, 2009.

61. SCHAFMEISTER, P.; ERGANG, R. Das Zustandsschaubild Eisen-NickelZinn. Arch. Eisenhüttenwes, n. 13, p. 95-103, 1939.

62. SUUTALA, N. Effect of manganese and nitrogen on the solidification mode in austenitic stainless steel welds. Metallurgical Transactions, v. 13A, n. 12, p. 2121-2130, 1982.

63. TAKALO, T.; SUUTALA, N.; MOISIO, T. Influence of ferrite content on its morphology in some austenitic weld metals. Metallurgical Transactions, v. 7A, $n$. 10, p. 1591-1592, 1976.

64. SIEVERT , T. A.; MC COWAN, C. N.; OLSON, D. Ferrite number prediction to $100 \mathrm{FN}$ in stainless steel weld metal. Weld. J. v. 67, n. 12, p. 289s-298s, 1988.

65. SUUTALA, N.; TAKALO, T.; MOISIO T. The relationship between solidification and microstructure in austenitic and austenitic-ferritic stainless steel welds. Metallurgical Transactions V. 10A, n. 4, p. 512-514, 1979.

66. DIXON, B. F. Control of magnetic permeability and solidification cracking in welded nonmagnetic steel. Weld. J. v. 68, n. 5, p. 171s-180s, 1989. 
67. BROOKS, J. A.; WILLIAMS, J. C; THOMPSON, A. W. Microstructural origin of the skeletal ferrite morphology of austenitic stainless steel welds. Metallurgical Transactions. v. 14A, n. 7, p. 1271-1281, 1983.

68. AMERICAN SOCIETY OF MECHANICAL ENGINEERS. ASME IX: Qualification standard for welding and brazing procedures, welders, brazers, and welding and brazing operators. 2011, p. 4-6.

69. MOTA, A. F. C. Ensaio de dobramento. Disponível em: <http://www.poli.br/ afcm/METALURGIA\%20DA\%20SOLDAGEM/METALURGIA\%2 ODA\%20SOLDAGEM\%201/ENSAIOS\%20MEC\%C2NICOS/ENSAIO\%20DE\%20DO BRAMENTO\%5b2\%5d\%20JULHO\%2006.ppt>. Acesso em 27/07/2011.

70. NETO, P. L. O. C. Estatística. São Paulo, Edgard Blücher, $2^{a}$ Ed, 2002, p. 107-115, 247. 


\section{ANEXO A - Resultados estatísticos dos ensaios Charpy}

Os valores obtidos para $Z_{\text {calc }}$ nas comparações de duas médias estão discriminados nas tabelas abaixo:

Tabela A.1: Valores de $Z_{\text {calc }}$ e $Z_{\text {crit }}$ na comparação entre as médias de energias absorvidas na superfície e na raiz.

\begin{tabular}{|c|c|c|c|c|c|}
\hline \multirow{2}{*}{$\begin{array}{c}\text { Corpo de } \\
\text { prova }\end{array}$} & $Z_{\text {calc }}$ & \multicolumn{3}{|c|}{$Z_{\text {crit }}$} \\
\cline { 5 - 6 } & & $0,1 \%$ & $0,5 \%$ & $1 \%$ & $5 \%$ \\
\hline $1(\mathrm{CA} / \mathrm{N})$ & 4,36 & & & & \\
\hline $2(\mathrm{CC} / \mathrm{N})$ & 1,26 & \multirow{2}{*}{3,27} & 2,81 & 2,57 & 1,96 \\
\hline $3(\mathrm{CC} / \mathrm{L})$ & 0,86 & & & & \\
\hline $4(\mathrm{CA} / \mathrm{L})$ & 2,05 & & & & \\
\hline
\end{tabular}

Tabela A.2: Valores de $Z_{\text {calc }}$ e $Z_{\text {crit }}$ na comparação entre as médias de energias absorvidas para mesmos tipos de corrente.

\begin{tabular}{|c|c|c|c|c|c|c|}
\hline \multirow{2}{*}{\multicolumn{2}{|c|}{ Corpos de prova }} & \multirow{2}{*}{$Z_{\text {calc }}$} & \multicolumn{4}{|c|}{$Z_{\text {crit }}$} \\
\hline & & & $0,1 \%$ & $0,5 \%$ & $1 \%$ & $5 \%$ \\
\hline \multirow{2}{*}{ CC } & $2(\mathrm{~N}) \times 3(\mathrm{~L})(\mathrm{sup})$ & 6,20 & \multirow{4}{*}{3,27} & \multirow{4}{*}{2,81} & \multirow{4}{*}{2,57} & \multirow{4}{*}{1,96} \\
\hline & $2(\mathrm{~N}) \times 3(\mathrm{~L})$ (raiz) & 8,20 & & & & \\
\hline \multirow{2}{*}{ CA } & $1(\mathrm{~N}) \times 4(\mathrm{~L})(\mathrm{sup})$ & 6,18 & & & & \\
\hline & $1(\mathrm{~N}) \times 4(\mathrm{~L})$ (raiz) & 1,01 & & & & \\
\hline
\end{tabular}

Tabela A.3: Valores de $Z_{\text {calc }}$ e $Z_{\text {crit }}$ na comparação entre as médias de energias absorvidas para mesmos tipos de fluxo.

\begin{tabular}{|c|c|c|c|c|c|c|}
\hline \multirow{2}{*}{\multicolumn{2}{|c|}{ Corpos de prova }} & \multirow{2}{*}{$Z_{\text {calc }}$} & \multicolumn{4}{|c|}{$Z_{\text {crít }}$} \\
\hline & & & $0,1 \%$ & $0,5 \%$ & $1 \%$ & $5 \%$ \\
\hline \multirow{2}{*}{$\mathrm{N}$} & 1 (CA)x 2 (CC) (sup) & 4,09 & \multirow{4}{*}{3,27} & \multirow{4}{*}{2,81} & \multirow{4}{*}{2,57} & \multirow{4}{*}{1,96} \\
\hline & 1 (CA)x 2 (CC) (raiz) & 2,58 & & & & \\
\hline \multirow{2}{*}{ L } & $3(\mathrm{CC}) \times 4$ (CA) (sup) & 4,03 & & & & \\
\hline & 3 (CC) $\times 4$ (CA) (raiz) & 7,70 & & & & \\
\hline
\end{tabular}


Tabela A.4: Valores de $Z_{\text {calc }}$ e $Z_{\text {crít }}$ na comparação entre as expansões laterais para mesmos tipos de corrente.

\begin{tabular}{|c|c|c|c|c|c|c|}
\hline \multirow{2}{*}{\multicolumn{2}{|c|}{ Corpos de prova }} & \multirow{2}{*}{$Z_{\text {calc }}$} & \multicolumn{4}{|c|}{$Z_{\text {crít }}$} \\
\hline & & & $0,1 \%$ & $0,5 \%$ & $1 \%$ & $5 \%$ \\
\hline \multirow{2}{*}{$\mathrm{CC}$} & $2(N) \times 3(L)(\sup )$ & 5,01 & \multirow{4}{*}{3,27} & \multirow{4}{*}{2,81} & \multirow{4}{*}{2,57} & \multirow{4}{*}{1,96} \\
\hline & $2(\mathrm{~N}) \times 3(\mathrm{~L})($ raiz) & 0,26 & & & & \\
\hline \multirow{2}{*}{ CA } & $1(\mathrm{~N}) \times 4(\mathrm{~L})(\mathrm{sup})$ & 2,50 & & & & \\
\hline & $1(\mathrm{~N}) \times 4(\mathrm{~L})$ (raiz) & 0,36 & & & & \\
\hline
\end{tabular}

Tabela A.5: Valores de $Z_{\text {calc }}$ e $Z_{\text {crít }}$ na comparação entre as expansões laterais para mesmos tipos de fluxo.

\begin{tabular}{|c|c|c|c|c|c|c|}
\hline \multirow{2}{*}{\multicolumn{2}{|c|}{ Corpos de prova }} & \multirow{2}{*}{$Z_{\text {calc }}$} & \multicolumn{4}{|c|}{$Z_{\text {crit }}$} \\
\hline & & & $0,1 \%$ & $0,5 \%$ & $1 \%$ & $5 \%$ \\
\hline \multirow{2}{*}{$\mathrm{N}$} & $1(\mathrm{CA}) \times 2(\mathrm{CC})(\mathrm{sup})$ & 0,98 & \multirow{4}{*}{3,27} & \multirow{4}{*}{2,81} & \multirow{4}{*}{2,57} & \multirow{4}{*}{1,96} \\
\hline & 1 (CA)x 2 (CC) (raiz) & 0,54 & & & & \\
\hline \multirow{2}{*}{ L } & 3 (CC) $\times 4$ (CA) (sup) & 2,96 & & & & \\
\hline & 3 (CC) $\times 4$ (CA) (raiz) & 0,06 & & & & \\
\hline
\end{tabular}




\section{ANEXO B - Relação entre expansão lateral e energia absorvida nos ensaios Charpy}

A partir dos dados da tabela 4.16, obteve-se os gráficos das figuras B.1 a B.4, que apresentam, respectivamente, a expansão lateral em função da energia absorvida nas regiões dos passes de solda da face e da raiz para os corpos de prova $1(\mathrm{CA} / \mathrm{N}), 2(\mathrm{CC} / \mathrm{N}), 3(\mathrm{CC} / \mathrm{L})$ e $4(\mathrm{CA} / \mathrm{L})$. Também foram plotados os gráficos das figuras B.5 e B.6 os quais representam, respectivamente, a expansão lateral em função da energia absorvida para os quatro corpos de prova nas regiões dos passes de solda da raiz e da face.

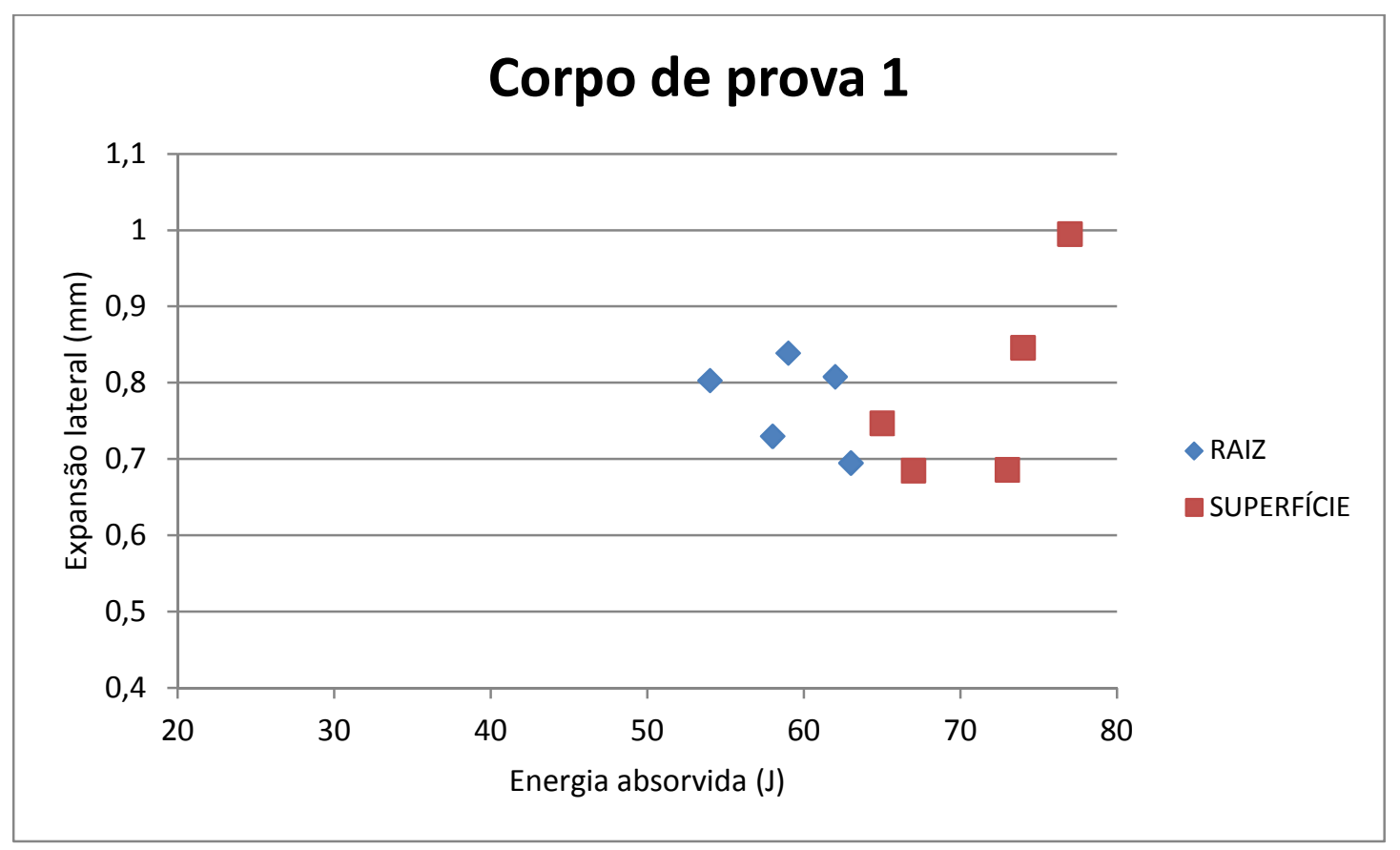

Figura B.1: Expansão lateral em função da energia absorvida nas regiões dos passes de solda da face e da raiz para o corpo de prova $1(\mathrm{CA} / \mathrm{N})$. 


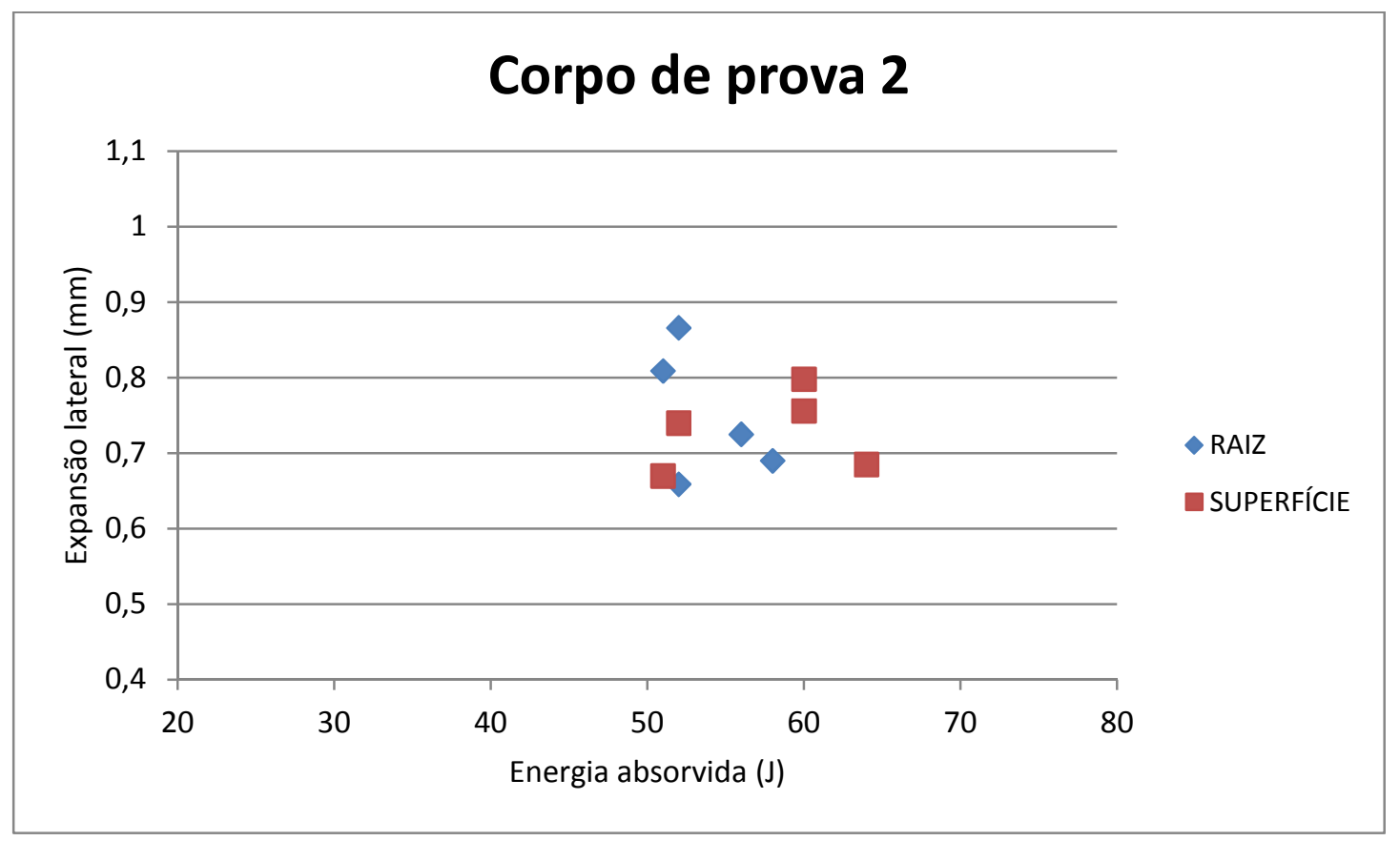

Figura B.2: Expansão lateral em função da energia absorvida nas regiões dos passes de solda da face e da raiz para o corpo de prova $2(\mathrm{CC} / \mathrm{N})$.

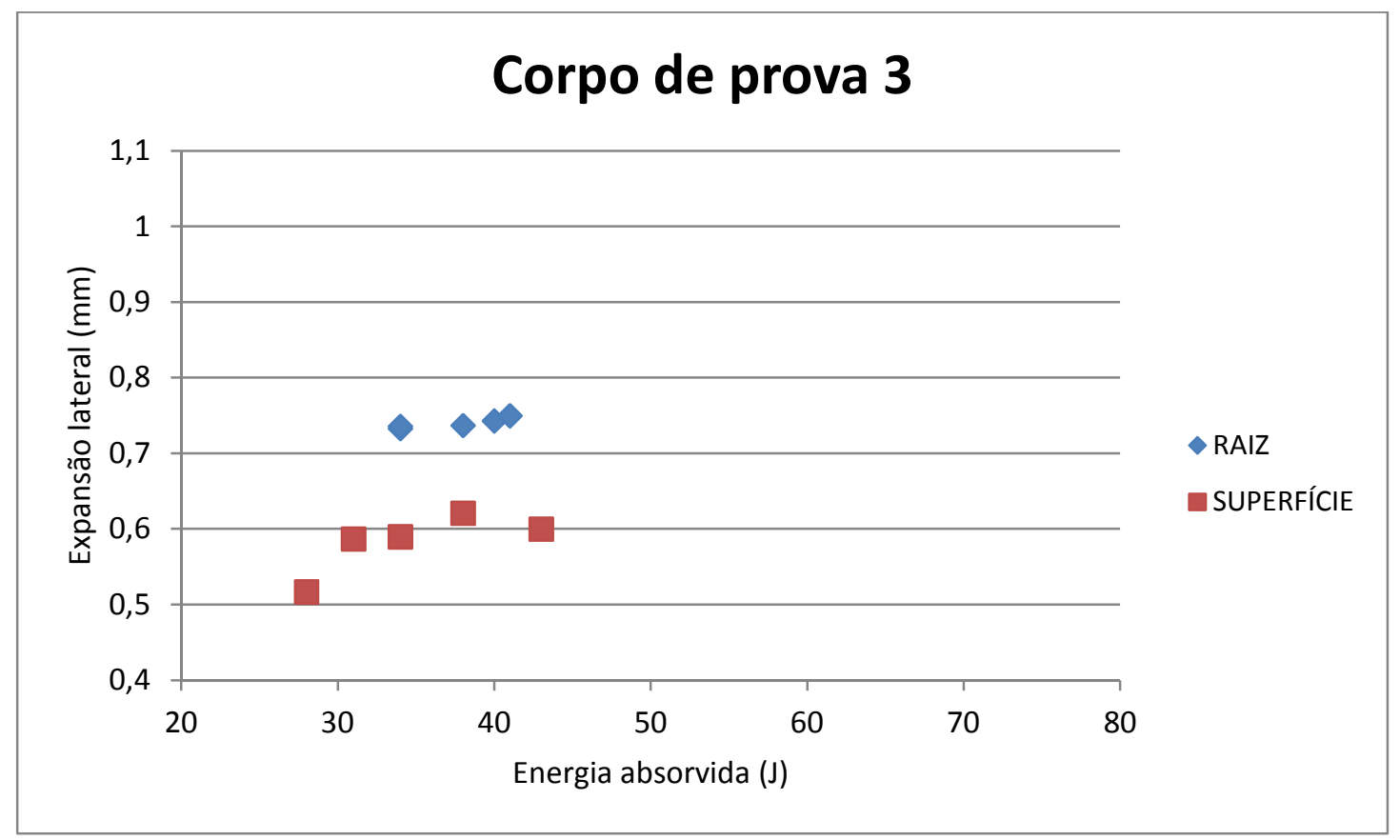

Figura B.3: Expansão lateral em função da energia absorvida nas regiões dos passes de solda da face e da raiz para o corpo de prova 3 (CC/L). 


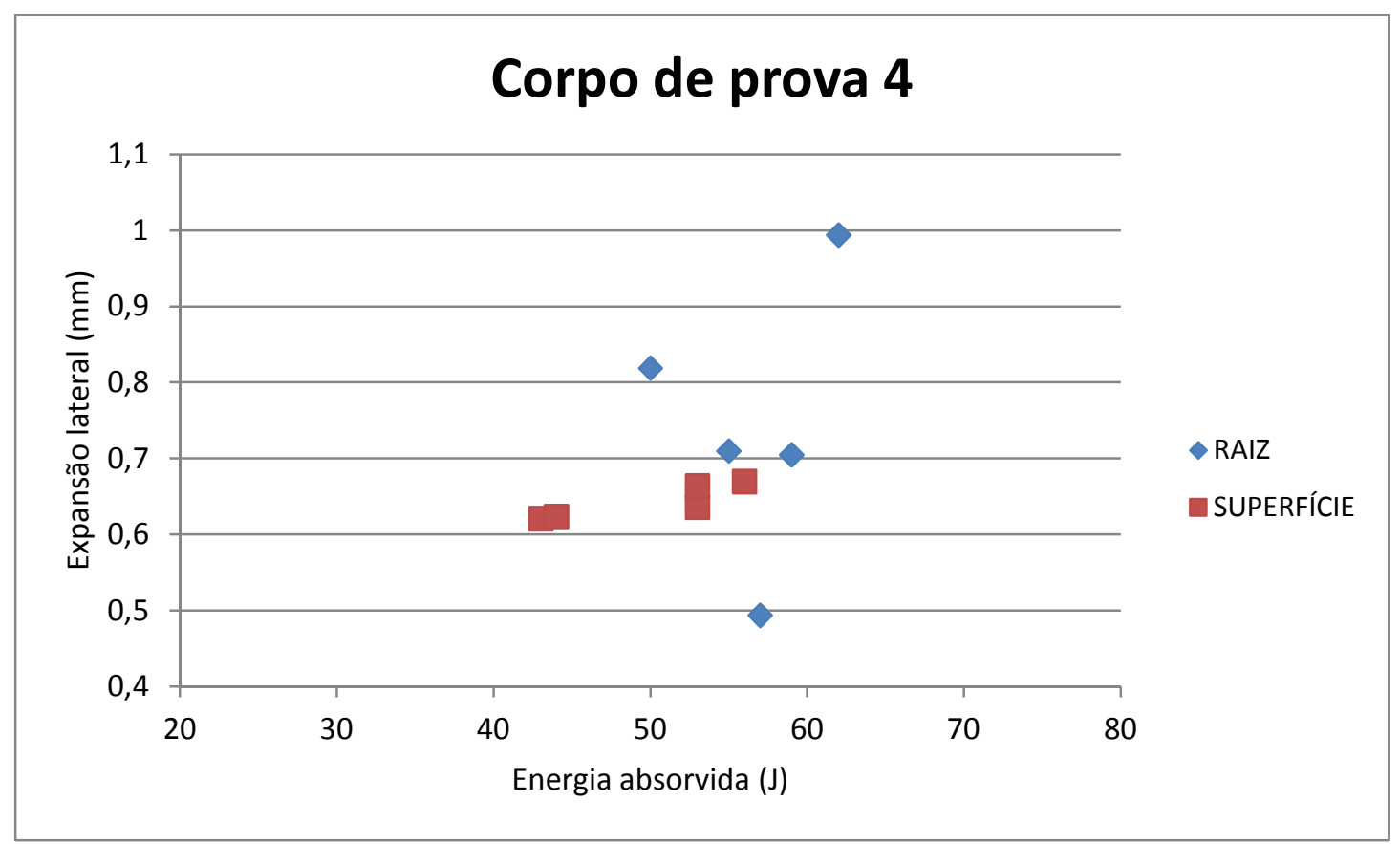

Figura B.4: Expansão lateral em função da energia absorvida nas regiões dos passes de solda da face e da raiz para o corpo de prova $4(\mathrm{CA} / \mathrm{L})$.

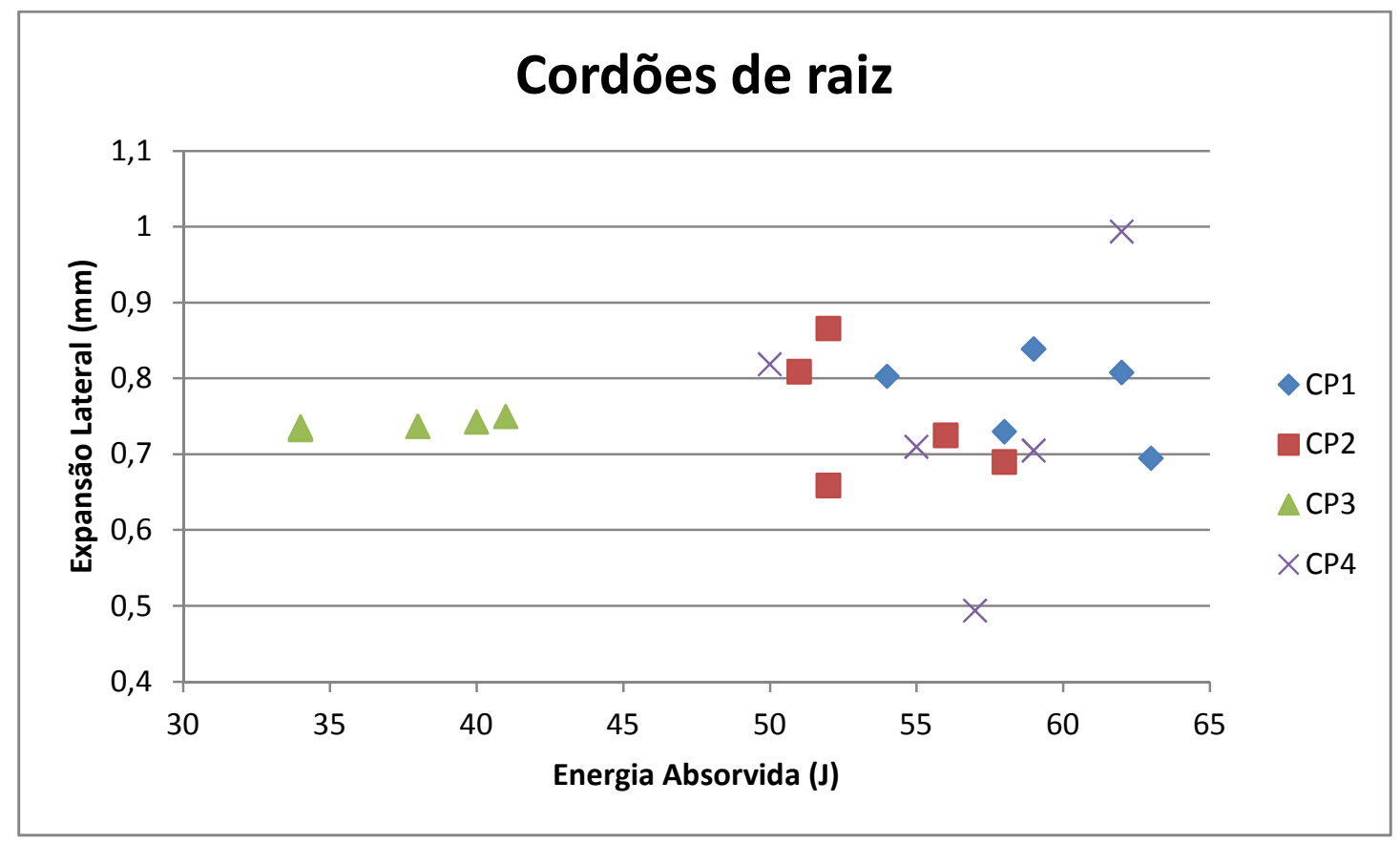

Figura B.5: Expansão lateral em função da energia absorvida para os quatro corpos de prova nas regiões dos passes de solda da raiz. 


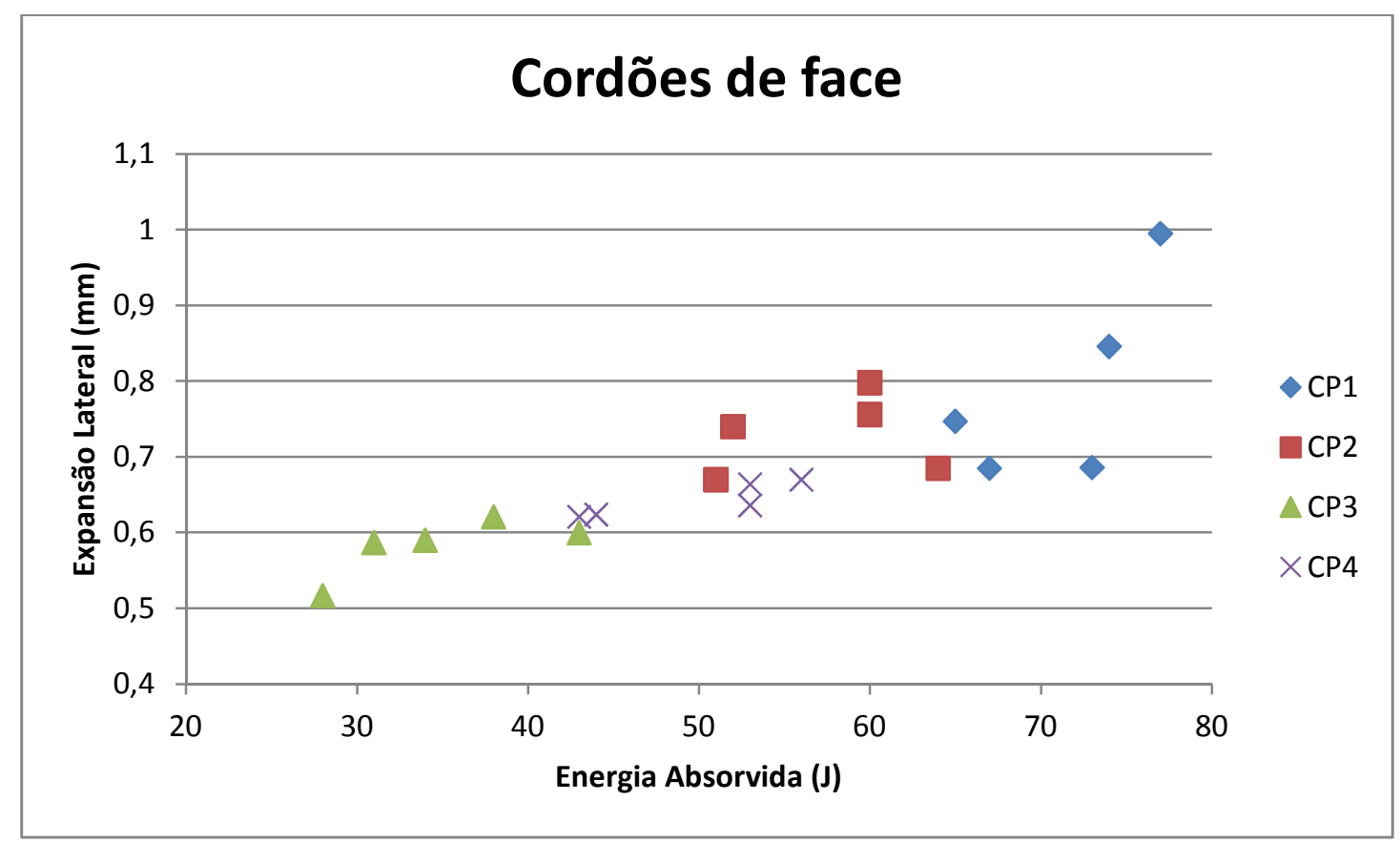

Figura B.6: Expansão lateral em função da energia absorvida para os quatro corpos de prova nas regiões dos passes de solda da face.

Conforme se pode observar nos gráficos anteriores, nos ensaios Charpy não se verificou nenhuma relação direta entre a energia absorvida no impacto com a expansão lateral. 